UNIVERSIDADE DE SÃO PAULO

FACULDADE DE FILOSOFIA, LETRAS E CIÊNCIAS HUMANAS

DEPARTAMENTO DE LETRAS CLÁSSICAS E VERNÁCULAS

PROGRAMA DE PÓS-GRADUAÇÃO EM FILOLOGIA E LÍNGUA

PORTUGUESA

\title{
As falácias no debate político eleitoral - uma visão Pragmadialética
}

Cleide Lucia da Cunha Rizério e Silva

Tese apresentada ao programa de Pósgraduação em Filologia e Língua Portuguesa, do departamento de Letras Clássicas e Vernáculas, da Faculdade de Filosofia, Letras e Ciências Humanas, da Universidade de São Paulo, para obtenção do título de Doutor.

Orientador: Prof $^{\mathrm{a}} \mathrm{Dr}^{\mathrm{a}}$ Zilda Gaspar Oliveira de Aquino.

Versão corrigida

São Paulo

2013 
CLEIDE LUCIA DA CUNHA RIZÉRIO E SILVA

\section{AS FALÁCIAS NO DEBATE POLÍTICO ELEITORAL - UMA VISÃO PRAGMADIALÉTICA}

Tese apresentada ao programa de Pósgraduação em Filologia e Língua Portuguesa, do departamento de Letras Clássicas e Vernáculas, da Faculdade de Filosofia, Letras e Ciências Humanas, da Universidade de São Paulo, para obtenção do título de Doutor.

Área de concentração: Filologia e Língua Portuguesa.

Orientador: Prof $^{\mathrm{a}} \mathrm{Dr}^{\mathrm{a}}$ Zilda Gaspar Oliveira de Aquino. 
Nome: Cleide Lucia da Cunha Rizério e Silva.

Título: As falácias no debate político eleitoral - uma visão Pragmadilética.

Tese apresentada à Faculdade de Filosofia, Letras e Ciências Humanas da Universidade de São Paulo para obtenção do título de Doutor em Filologia e Língua Portuguesa.

Aprovado em:

Banca Examinadora

Prof. Dr. Instituição:

Julgamento: Assinatura:

Prof. Dr. Instituição:

Julgamento: Assinatura:

Prof. Dr. Instituição:

Julgamento: Assinatura:

Prof. Dr. Instituição:

Julgamento: Assinatura:

Prof. Dr. Instituição:

Julgamento: Assinatura: 
Para o Pedro

Um sonho acalentado, um medo domado, uma verdade avassaladora. 
Agradecimentos

A Deus, pela força, coragem, perseverança e fé em momentos que a vida as exigiu.

A minha mãe, pelos ideais, conceitos, crenças e valores.

Ao meu pai, por me tornar mais forte.

Ao meu marido, por acreditar que minhas conquistas seriam possíveis e pelo companheirismo em muitos momentos de dúvida e incerteza e também naqueles de alegria imensa.

A minha orientadora, por, além de oferecer direcionamento acadêmico, desempenhar a difícil função de estar sempre disponível para ouvir, aconselhar, encorajar, apoiar, impor limites (sempre quando necessário) e acima de tudo por compreender angústias e dissipá-las.

Ao meu grande amigo Vicente Castro, por estar ao meu lado sempre e sei que assim continuará.

Aos meus amigos, companheiros de discussões teóricas e cafés: Daniela Miranda e Paulo Roberto Gonçalves Segundo.

A Charles e Inês Brown, pela ajuda na coleta dos dados que compõem o corpus .

Aos familiares, pelas palavras de encorajamento e apoio.

A Alcilene Aguiar, pelo auxílio em momentos importantes.

Aos amigos que a vida me trouxe: Flávia, Alice, Aninha, Paulinha, Rudmar, Carlinha, Ana Luísa, Solange, e tantos outros que deixaram inúmeros momentos mais felizes.

Aos professores e colegas do GEDUSP, pelo meu crescimento acadêmico por meio do debate de ideias.

Aos professores Leonor Lopes Fávero e José Gaston Hilgert pelas contribuições fundamentais quando da qualificação da presente tese.

A Fundação de amparo à pesquisa do estado de São Paulo - FAPESP- pela bolsa concedida. 
RESUMO

Neste estudo, temos por proposta observar o debate político eleitoral, de modo a caracterizá-lo como um evento polêmico em que as opiniões não configuram o objeto principal do discurso dos interlocutores. Acreditamos que os participantes de tal gênero discursivo utilizam manobras argumentativas, que constituem falácias, como uma estratégia; entretanto, tal prática pode acarretar consequências ou efeitos diferentes daquelas tradicionalmente decorrentes de tal manobra. Como fundamentação teórica, aplicamos os conceitos da Teoria Pragmadialética da Argumentação (van Eemeren e Grootendorst: 1984, 1992, 2004), de certa forma conectada à Dialética, mas que apresenta diferenças importantes, principalmente por meio da dicotomia entre os termos "Formal" e "Pragma" (derivada de Pragmática). Os elementos pragmáticos que esse termo pressupõe referem-se à Teoria dos Atos de Fala e à Análise do discurso, inspiradas pelas descobertas dos filósofos que analisam a linguagem do cotidiano. Tratamos do emprego da falácia como uma espécie de inobservância às Regras de Discussão Crítica - regras que fazem referência a um comportamento, ou ação, pelo qual os interlocutores são responsáveis. Cada tipo de falácia pode ocorrer em um determinado estágio de discussão crítica, a qual corresponde a um modelo que apresenta estágios distintos, analiticamente, no processo de solucionar uma discussão, e cada violação às regras da discussão crítica pode tornar a resolução da diferença de opinião mais difícil ou mesmo impossível, configurando-se uma falácia. Tais violações são realizadas por meio de atos de fala dos tipos assertivo, comissivo, diretivo, declarativo ou declarativo de uso. A metodologia a ser utilizada constitui-se da observação das unidades de análise (os turnos de fala dos participantes), de modo a classificar a ocorrência das falácias. O corpus selecionado refere-se a debates políticos eleitorais exibidos pela mídia televisiva, no ano de 2008, referentes às eleições à prefeitura da cidade São Paulo-SP.

Palavras-chave: Argumentação, Falácias, Pragmadialética, Debate político eleitoral. 


\section{ABSTRACT}

This paper deals with political debate, in order to analyze if the opinions are truly the aim of this kind of discourse and some of the strategic arguments, that can be understand as fallacies, would be find. At the Pragma-dialectical approach of argumentation (van Eemeren e Grootendorst: 1984, 1992, 2004) the concept of fallacies could be better understood as one impediment to the resolution of a disagreement. The theory proposes ten rules for the conduct of an ideal model of a "critical discussion". A fallacy is a violation of one of the ten rules. Generically, such fallacies are moves which disrupt or "derail" the process of rationally resolving an expressed difference of opinion. A fallacy can happen in the various stages of a critical discussion by the performance of speech acts: comissives, directives, expressive and declaratives. The methodology is the observation of the speech acts of the participants on a debate in order to verify the fallacies that can occur. Political debates from 2008, for the mayor of Sao Paulo election is the corpus selected.

Key words: Argumentation, Fallacies, Pragma-dialectics, political debate. 


\section{ÍNDICE DE QUADROS}

Quadro 1- Constituição da tipologia da polêmica 33

Quadro 2 - O método para pesquisa da argumentação proposto pela Pragmadialética.

Quadro 3 - Comparação entre os métodos de pesquisa da Retórica e da Dialética 96

Quadro 4- As violações às regras do Código de conduta para os participantes da discussão crítica

Quadro 5 - Falácias tradicionais e sua definição na Pragmadialética..136 Quadro 6 - Falácias tradicionais e sua definição na Pragmadialética...146 Quadro 7 - Resultados da análise das falácias 179

Quadro 8-As falácias ad hominem. 180 
SUMÁRIO

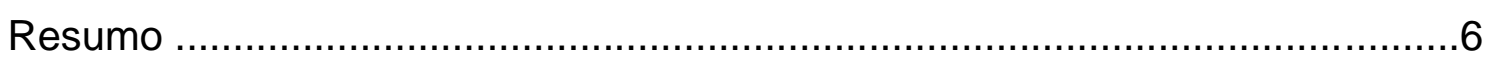

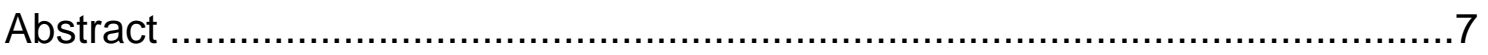

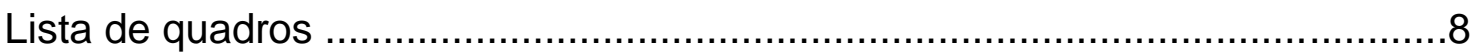

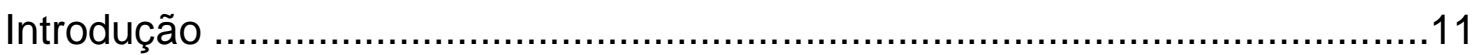

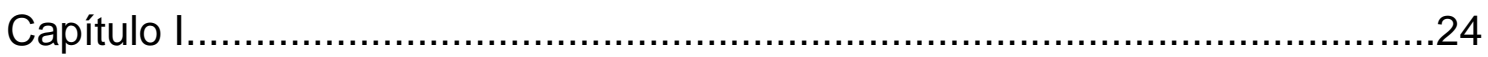

Debate Político Eleitoral - características e especificidades de uma manifestação polêmica

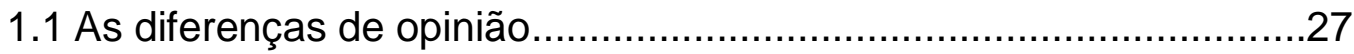

1.2 A discordância e a discussão argumentativa .................................28

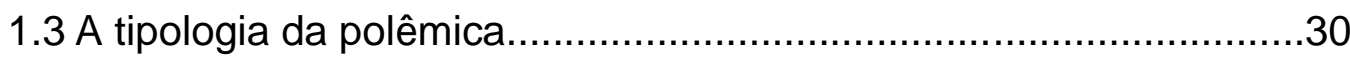

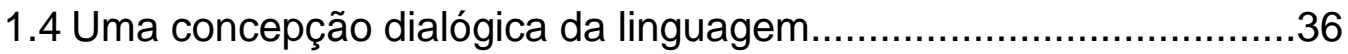

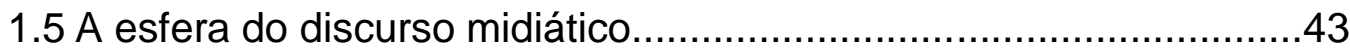

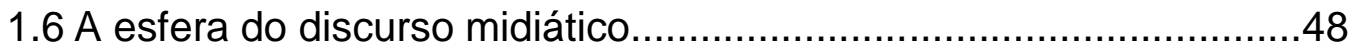

1.7 A constituição do debate político eleitoral.......................................58

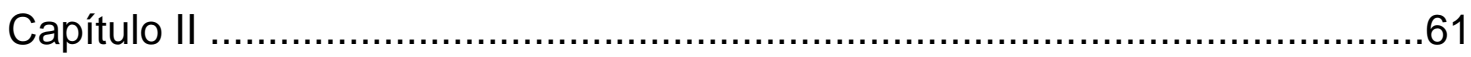

Teorias da Argumentação - diferentes perspectivas

2.1 As teorias que tratam da Argumentação - diálogos com a

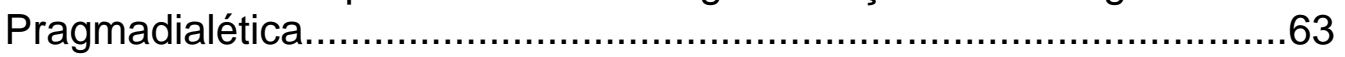

2.1.1 Toulmin e seu modelo de análise ................................ 64

2.1.2 A Nova Retórica de Perelman e Olbrechts-Tyteca..........66

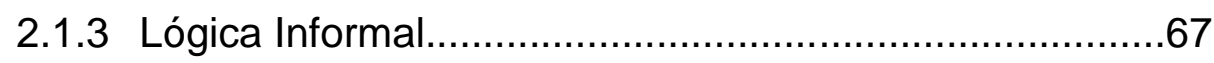

2.1.4 Semântica Argumentativa...............................................69

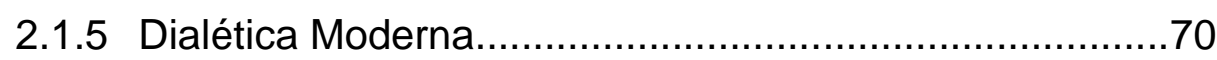

2.1.6 Retórica Moderna..........................................................

2.2 Fundamentos da Pragmadialética enquanto teoria da

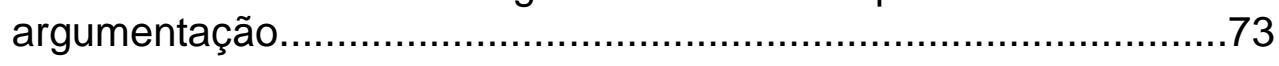

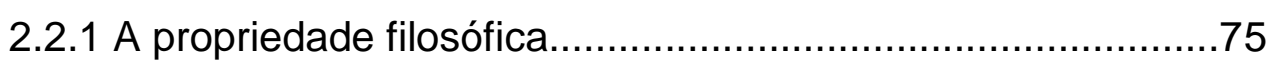

2.2.2 A propriedade teórica........................................................79

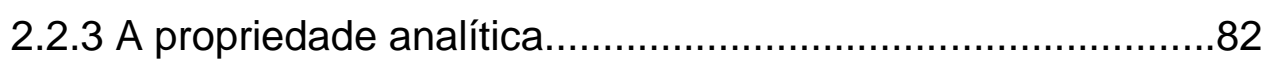

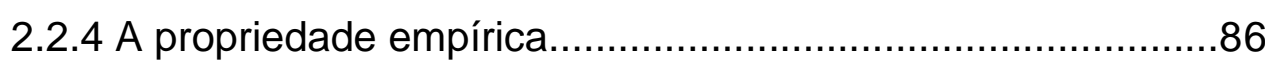

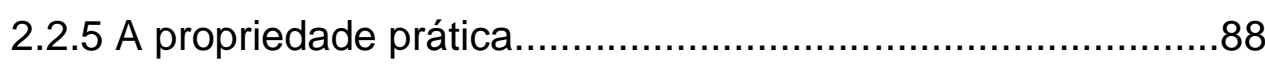

2.2.6 Um programa para o estudo da argumentação......................94 
2.3 A Pragmadialética e as funções do estudo da argumentação......................................................................

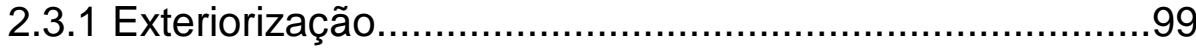

2.3.2 Socialização............................................................100

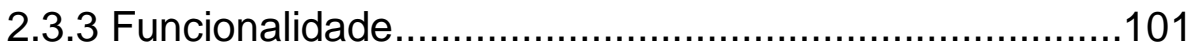

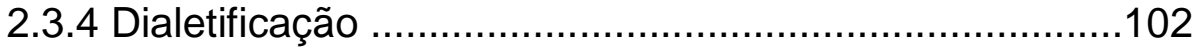

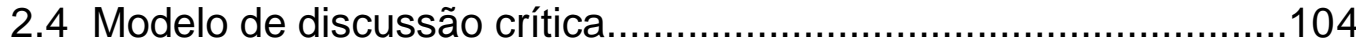

2.5 Código de conduta para os participantes de uma discussão crítica 106

2.6 O conceito de falácia na Pragmadialética................................ 108

Capítulo III

Falácias - um percurso até os dias atuais

3.1 De Aristóteles aos preceitos da Lógica Formal.............................112

3.2 As falácias na Lógica Informal.................................................118

3.3 As falácias como uma violação a regras na visão

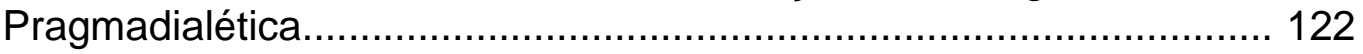

3.3.1 Violações das regras no estágio de confrontação............... 125

3.3.2 Violações das regras no estágio de abertura ......................126

3.3.3 Violações das regras no estágio de argumentação..............127

3.3.4 Violações da regra no estágio de conclusão........................130

3.4 As possíveis violações das regras da discussão crítica...................131

3.4.1 Falácias tradicionais como violações às regras da discussão

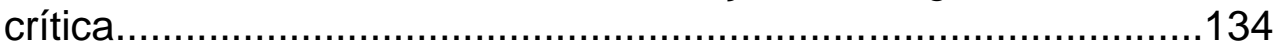

Capítulo IV

Análise do corpus

4.1 A análise

Conclusão 174

Referências bibliográficas. 183

Anexos 
INTRODUÇÃO 
Desde os estudos retóricos de Aristóteles, diversas correntes teóricas, a partir do século XX, interessaram-se pelo estudo da argumentação; dentre elas, destacam-se a Nova Retórica de Perelman e Olbrechts-Tyteca (2002 [1958]), segundo a qual a argumentação está ligada ao uso de técnicas e estratégias; além disso, destaca o conceito de auditório; a teoria de Toulmin (1958), em especial, no que se refere ao seu modelo de argumentação, um procedimento formal para argumentar ou uma descrição das diversas etapas que podem ser caracterizadas no ato de defender uma opinião.

Ainda, ressalta-se a Lógica Informal de Walton (1992), Blair e Johnson (1987), que apresentam um novo procedimento quanto ao estudo normativo da argumentação na linguagem do cotidiano, observando uma relação mais evidente entre este e a prática argumentativa, e desenvolvem normas e procedimentos para a análise da argumentação de maneira lógica. Destaca-se ainda, entre outras, a Pragmadialética, que tem Van Eemeren (1983), como um dos fundadores, a qual se preocupa com o conceito de discussão crítica e estabelece uma série de regras que norteiam o estudo da argumentação.

A Pragmadialética, teoria que selecionamos para fundamentar teoricamente nossa pesquisa, apresenta o pressuposto essencial de defender a confluência teórica em torno do estudo da argumentação, de modo a alicerçar adequadamente suas pesquisas, no que concerne à questão metodológica. Para tanto, essa teoria estabelece um diálogo com outras, para efeito de comparação, complemento e/ou crítica.

Os estudos sobre a argumentação no Brasil pouco se referem à Pragmadialética, a ponto de torná-la quase desconhecida da maioria dos 
estudiosos da Argumentação no país. Nesse sentido, nossa seleção teórica decorre de nossa crença na necessidade de que novas propostas teóricas devam ser estudadas e analisadas sem qualquer juízo crítico valorativo preconcebido e com a função de trazer esclarecimentos e novos olhares a esse campo fértil da linguagem e da interação.

Nesta pesquisa, optou-se por desenvolver algo pouco explorado nos estudos derivados dessa corrente: a questão das falácias no âmbito cultural do Brasil. Destaca-se que há pesquisas que as observam em outros contextos culturais, em especial no europeu, de modo a conceituar e analisar empiricamente a aplicabilidade do método proposto pela teoria.

Neste trabalho, analisamos as falácias em um gênero essencialmente polêmico - o debate político eleitoral, e temos por hipótese que os participantes de tal gênero utilizam-se das falácias como uma estratégia argumentativa para mudar o tópico em discussão.

Essa hipótese leva-nos a questionar: 1) Como se constitui o gênero, debate político eleitoral, em termos dos preceitos da Pragmadialética? 2) A Pragmadialética prevê, em seus pressupostos, o uso das falácias com o propósito discursivo de ser esse um argumento que produz resultados, destacando que tal prática pode acarretar consequências ou efeitos diferentes daquelas tradicionalmente decorrentes de tal manobra - será que isso se verifica em nosso corpus? 3) No debate político eleitoral as opiniões apresentam-se como alicerce - conforme orienta a Pragmadialética, no que se refere à constituição da discussão crítica? 4) As opiniões cumpririam o papel de 
tentar diluir ataques pessoais e ofensivos? 5) Esses ataques e críticas consistem na ocorrência de uma falácia conforme propõe a Pragmadialética?

A problematização conduz-nos aos seguintes objetivos:

- Observar de que modo se aplicam os pressupostos da Pragmadialética - conceitos-chave que permitem compreender o processo de discussão crítica em nosso corpus, tendo em vista um evento específico - debate político eleitoral - com participantes também específicos - políticos em campanha;

- Detectar, no debate político eleitoral, as regularidades linguísticodiscursivas que se apresentam, visando à compreensão dos procedimentos adotados pelos participantes que constituem esse evento polêmico-discursivo;

- Investigar, em nosso corpus, a ocorrência de falácias derivadas de ataques pessoais em termos de violação ao código de conduta para os participantes de uma discussão crítica, conforme proposto pela Pragmadialética.

- Identificar o gênero que compõe o corpus, influenciado pelas características da esfera discursiva, conforme o conceito derivado dos estudos de Bakhtin, e do contexto cultural, observando o uso da manobra argumentativa que caracteriza a falácia.

Quanto aos procedimentos metodológicos adotados em nosso trabalho, ressaltamos a coleta do corpus, que se constituiu em debates políticos eleitorais, reunido por ocasião da campanha à Prefeitura de São Paulo, em 2008, tendo em vista que o discurso político, em seu gênero debate, pode 
constituir um campo fértil ao uso da argumentação e à ocorrência de falácias, utilizadas estrategicamente.

Para que pudéssemos observar o discurso dos participantes, utilizamos as gravações em vídeo de quatro (04) debates realizados por emissoras de TV brasileiras (não-estatais) com os candidatos à Prefeitura Municipal da cidade de São Paulo, no ano de 2008. Elas perfazem um total de, aproximadamente, oito (08) horas e foram transcritas de acordo com as normas do Projeto da Norma Urbana Culta (NURC/SP).

O primeiro dos debates refere-se ao evento transmitido pela Rede Bandeirante de Rádio e Televisão, em 11 de setembro de 2008, referente ao primeiro turno das eleições. Contou com a participação de Ivan Valente (PSOL), Gilberto Kassab (DEM), Soninha Francine (PPS), Renato Reichmann (PMN), Marta Suplicy (PT), Ciro Moura (PTC), Geraldo Alckmin (PSDB) e Paulo Maluf (PP) e o jornalista Boris Casoy como apresentador/mediador. Essa amostragem do corpus perfaz um total de cento e quarenta minutos e vinte e cinco segundos.

Os debates seguintes referem-se àqueles realizados com a participação dos candidatos ao segundo turno das eleições, que foram Marta Suplicy (PT) e Gilberto Kassab (DEM). O primeiro ocorreu em 12 de outubro de 2008 e foi transmitido pela Rede Bandeirante de Rádio e Televisão e contou, novamente, com a participação do jornalista Boris Casoy como apresentador/mediador, totalizando cento e dezenove minutos e quarenta segundos de duração. 
Os posteriores ocorreram, respectivamente, em 19 de outubro de 2008, veiculado pela Rádio e Televisão Record S/A, com duração de cento e nove minutos e quarenta e nove segundos, em que o jornalista Celso Freitas esteve no papel de mediador; em 24 de outubro de 2008, transmitido pelo Sistema Globo de Rádio e Televisão, neste caso, o mediador foi o jornalista Chico Pinheiro, totalizando cem minutos e quarenta e seis segundos de duração ${ }^{1}$.

Procedeu-se à análise qualitativa dos dados coletados, tendo por unidade de análise os atos de fala dos interlocutores em seus turnos ${ }^{2}$ de fala, durante o desenvolvimento de seus tópicos, de modo a caracterizar, ou não, as violações ao código de conduta e a consequente utilização da falácia.

Classificamos as amostras dos eventos discursivos analisados, os debates políticos eleitorais, de acordo com os preceitos da Pragmadialética, amparados pelo conceito de discussão crítica e sua constituição em quatro partes, conforme propõe essa teoria e discutiremos a seguir, de modo a verificar se os estágios têm sua ocorrência no corpus selecionado, seja de modo implícito ou explícito.

O processo de observação consistiu da seleção das falácias a cada discurso dos interlocutores e em cada uma das amostragens do corpus, especificamente no terceiro estágio da discussão crítica: a argumentação, para computar, nos resultados da análise, as possíveis ocorrências de falácias e a detectar quando o seu uso é, ou não, estratégico. A razão de selecionarmos

\footnotetext{
${ }^{1} \mathrm{O}$ vencedor do pleito eleitoral foi o candidato Gilberto Kassab.

2 Utilizaremos a terminologia da Análise da Conversação (MARCUSCHI, 1986), por entendermos que se trata de um evento real de fala.
} 
esse estágio decorreu do fato de se tratar da parte mais profícua na realização de movimentos discursivos estratégicos.

Nosso recorte faz-se a partir da observação das interações discursivas dos participantes de uma discussão crítica, amparando-nos no "código de conduta para os participantes da discussão crítica", apresentado pela teoria Pragmadialética, tendo em vista o emprego das falácias derivadas do comportamento dos interlocutores.

Referindo-nos à teoria que selecionamos como alicerce de nosso estudo, destacamos que a Pragmadialética nomeia-se face a duas dimensões: a dimensão dialética de sua abordagem, que caracteriza a argumentação como parte de uma discussão crítica, com vistas a resolver uma diferença de opinião, e a dimensão pragmática, que considera o discurso argumentativo um fenômeno do uso da linguagem na comunicação entre interlocutores ou escritores e leitores.

O principal representante dessa teoria, como já o dissemos, é Frans van Eemeren, membro-fundador da ISSA (International Society for The Study of Argumentation $)^{3}$. As ferramentas conceituais derivadas da Filosofia e da Pragmática ocupam o papel central na Pragmadialética. Considera, sobremaneira, a relevância dos atos de fala para a solução da discordância em um diálogo, bem como avalia todos os "moves" ${ }^{4}$ discursivos que possuam importância argumentativa.

\footnotetext{
${ }^{3}$ Para maiores informações, acessar: http://cf.hum.uva.nl/issa/about.html.

${ }^{4}$ Refere-se ao conceito de "move", a unidade discursiva mínima que representa um turno na interação, destinado à formulação de uma intenção comunicativa do falante. Durante um diálogo, um turno pode consistir em vários "moves".
} 
Com o propósito de criar um método de análise da argumentação, a Pragmadialética apresenta um modelo idealizado de discussão crítica que se refere ao ideal socrático de submeter todas as crenças de um indivíduo a um exame dialético, observando-se não apenas os fatos e declarações, mas também os julgamentos de valor e os pontos de vista. Toma tal modelo como plano teórico para definir um procedimento de teste crítico aos pontos de vista ou opiniões, de acordo com os comprometimentos assumidos na realidade empírica do discurso argumentativo. Esse modelo provê um resumo da estrutura do discurso argumentativo e tem por objetivo a criação de uma metodologia que visa a resolver uma diferença de opinião.

A Pragmadialética pode ser considerada uma escola teórica que aborda tanto a linguagem, enquanto um sistema simbólico passível de análise e de caracterização, quanto o campo da interação. Isso ocorre devido ao fato de considerar a argumentação uma ferramenta de atuação entre os interlocutores, os quais participam da forma suprema de apreensão e evolução do conhecimento: a discussão argumentativa.

Sempre que uma opinião é posta à prova, ela tem de ser fortalecida por meio da argumentação, para se manter, caso contrário, deverá ser modificada e reformulada. Portanto, esse processo de contestar as opiniões por meio da discussão argumentativa enriquece e amplia o conhecimento daqueles que 0 compartilham, seja como participantes / oponentes ou auditório ${ }^{5}$.

O processo de usar a argumentação para interagir por meio das opiniões, colocando-as em contato e, frequentemente, em conflito, pode

\footnotetext{
${ }^{5}$ De acordo com o conceito de auditório proposto por Perelman \& Olbrechts-Tyteca (1958).
} 
ocasionar o surgimento de uma espécie de acordo ou convergência para um determinado ponto, uma nova opinião, geralmente mais bem fundamentada e superior em decorrência desse processo argumentativo.

Segundo van Eemeren e Grootendorst (2004), devido à essência da argumentação relacionar-se com um determinado modo organizacional destinado a convencer os outros sobre um ponto de vista, seu estudo torna-se, sob a ótica de uma perspectiva social, um dos mais importantes domínios do estudo do pensamento, já que ela não se limita a uma tomada de decisão democrática, podendo também ser considerada essencial para qualquer discussão intelectual e debate civilizado. Em decorrência desses fatores, seu estudo requer atenção unânime e ponderada, independentemente de qualquer posição favorável, ou contrária, a uma corrente formalista.

Para servir ao propósito de instrumentalizar a análise de uma discussão argumentativa, o modelo de discussão crítica, criado pela Pragmadialética, apresenta quatro estágios ou partes no processo de resolução da diferença de opinião, postos em prática pelos participantes de uma discussão argumentativa.

As seguintes partes, ou estágios, compõem o modelo de discussão crítica: Confrontação, Abertura, Argumentação e Conclusão. Na realização do discurso argumentativo, a cada estágio da discussão crítica presente no discurso, obstáculos específicos podem surgir e servir como impedimentos à solução da diferença de opinião, os quais apresentam uma amplitude idêntica aos movimentos tradicionalmente conhecidos como falácias, as quais também podem ser utilizadas como estratégias argumentativas. 
Outro conceito a ser destacado refere-se à criação de uma série de regras que possuem a função instrumental de possibilitar aos participantes da discussão a resolução da diferença de opinião; entretanto, conforme ressaltam van Eemeren e Grootendorst (2004), o procedimento da aplicação das regras da Pragmadialética em uma discussão crítica pode apresentar-se como tarefa de certa complexidade aos interlocutores comuns, participantes de discussões do cotidiano.

Assim, visando a facilitar a utilização desse procedimento, os autores sintetizam as regras em um código de conduta para os participantes de uma discussão crítica composto de dez princípios que constituem uma espécie de orientação a esses participantes. A conformidade, sem qualquer violação, aos princípios da Pragmadialética, segundo van Eemeren e Grootendorst (2004), possibilita uma discussão crítica clara e sem a ocorrência de situações apelativas.

$\mathrm{Na}$ prática cotidiana do discurso, pode-se encontrar um gênero discursivo que se configure como altamente argumentativo, mas que não corresponda, a primeira vista, ao modelo idealizado de discussão crítica ${ }^{6}$. Por conta disso, todo ato discursivo que pareça não pertencer ao escopo da teoria pode ser facilmente entendido como um obstáculo à sua aplicação metodológica. Entretanto, de acordo com van Eemeren, Garssen e Meuffels (2009, p. 25):

\footnotetext{
${ }^{6}$ Lembramos que é constituído pelos quatro estágios da discussão critica: confrontação, abertura, argumentação e conclusão.
} 
Uma análise realizada sob a perspectiva da Pragmadialética objetiva reconstruir todos e exclusivamente os elementos do discurso que são pertinentes ao processo de resolução. Tal reconstrução orientada à conclusão concentra-se em identificar os atos de fala que desempenham um papel em potencial em levar uma diferença de opinião à uma conclusão adequada. Nessa tentativa, os atos de fala irrelevantes ao processo de resolução são ignorados, os elementos implícitos são explicitados, os atos de fala indiretos são reafirmados como atos de fala diretos e desvios involuntários do caminho da resolução são rearranjados. [..... ${ }^{7}$

De acordo com a citação precedente, observa-se a instauração de uma metodologia de análise bastante clara e que pretende reconstruir a estrutura do discurso argumentativo de modo a realizar um exame minucioso de seu processo, em busca do fio condutor que leva à resolução numa atividade discursiva como é a discussão.

Van Eemeren e Grootendorst (2004) expõem orientações sobre a possível defesa de um ponto de vista ou opinião expressa e oferecem uma nova visão para o melhor entendimento das falácias, em relação àquelas já estabelecidas como a Lógica Formal, as quais, sob essa ótica, caracterizam-se como manobras estratégicas que devem ser entendidas como uma violação às regras da discussão crítica.

Apresentados os preceitos de nossa teoria central, ressaltamos que, nosso referencial teórico, além das obras de Van Eemeren e Grootendorst, introdutores da Pragmadialética (1983, 1992, 1996, 2004, 2009), acresce-se

\footnotetext{
${ }^{7}$ Tradução nossa de: "An analysis undertaken from a pragma-dialectical perspective is aimed at reconstructing all those and only those elements in the discourse that are pertinent to the resolution process. Such a resolution-oriented reconstruction concentrates on identifying the speech acts that play a potential part in bringing a difference of opinion to an adequate conclusion. In this endeavor, speech acts that are immaterial to the resolution process are ignored, implicit elements are made explicit, indirect speech acts are restated as direct speech acts, and unintentional swerves from the resolution path are rearranged".
} 
das pesquisas de Análise do Discurso desenvolvidas por Charaudeau (2006, 2007), quanto ao discurso político e da mídia, dos estudos filosóficos de Dascal (1999/2005/2008), especificamente em relação à teoria da Polêmica, além da Teoria Dialógica de Bakhtin (1993, 2003), seu criador e responsável pela caracterização de gênero que utilizamos em nosso estudo.

Tendo em vista a proposta desta pesquisa, o trabalho se organiza do seguinte modo:

Capítulo I - DEBATE POLítICO ELEITORAL - CARACTERÍSTICAS E ESPECIFICIDADES DE UMA MANIFESTAÇÃO POLÊMICA, no qual procedemos à observação do conceito de diferença de opinião, com base nos estudos sobre a polêmica, e à caracterização do debate político eleitoral como um gênero discursivo, amparando-nos nos estudos derivados do Círculo de Bakhtin, especialmente no que se refere aos conceitos de esfera discursiva e estrutura composicional, para que possamos classificar o gênero que compõe o nosso corpus. Tratamos, ainda, de referenciar os trabalhos que observam 0 discurso político, em especial o debate, para fundamentar nossa pesquisa.

No Capítulo II - TEORIAS DA ARGUMENTAÇÃO - DIFERENTES PERSPECTIVAS se encontra uma síntese das principais linhas teóricas que tratam da Argumentação e que influenciaram, fundamentalmente, a Pragmadialética, bem como a constituição de tal teoria, no que se refere aos seus componentes como conceitos, metodologia e orientações para a análise do discurso dos participantes de uma diferença de opinião que se utilizam da argumentação para resolvê-la. 
O Capítulo III: AS FALÁCIAS- UM PERCURSO ATÉ OS DIAS ATUAIS trata do conceito de falácia, apresentando um breve panorama dos estudos derivados da Lógica Formal, para dedicarmos maior atenção à conceituação da Lógica Informal e, principalmente, da Pragmadialética, que apresenta um novo modo de classificar as manobras discursivas tradicionalmente reconhecidas como falácias.

No Capítulo IV: ANÁLISES, procedemos à observação do corpus selecionado, amparando-nos nos conceitos da Pragmadialética, que se constitui no alicerce teórico de nosso trabalho. 


\title{
CAPÍTULO I-
}

\section{Debate Político Eleitoral -}

\author{
características e
}

especificidades de uma

manifestação polêmica 
Nosso trabalho insere-se no terreno correspondente ao caráter interativo da linguagem, tendo em vista que é por meio das ações linguageiras que entendemos a constituição do pensamento, das crenças e valores dos indivíduos. Nesse sentido, o processo de expor uma opinião que, em geral, apresenta-se como verdades pessoais, julgamentos, certezas pessoais, argumentos, discursos e convicções individuais e/ou coletivas pertencentes a todas as áreas, permite interagirmos e construirmos nossas relações sociais.

Um modo de definir a opinião refere-se à sua constituição enquanto uma espécie de representação do mundo em que vivemos, intrínseca ao indivíduo e responsável pela divulgação ou registro de ideias sobre a realidade e a mente humana. Pode-se dizer que constituem julgamentos sobre situações sociais, pessoais e políticas.

A opinião tem seu lugar nas percepções e representações do mundo, seja referente a acontecimentos ou fatos da sociedade. A subjetividade se faz presente e a manifestação da opinião pode dar-se de maneira dicotômica ou complexa, explícita e/ou implícita e cerceada ou não pelas mais diferentes formas de transmissão do discurso.

Conforme sabemos, os indivíduos que vivem em sociedade apresentam diferentes opiniões com fortes crenças nos mais variados campos de atuação humana; entretanto, qualquer que seja nossa opinião e por mais fortemente que a defendamos, devemos reconhecer que elas, de fato, constituem-se em proposições argumentativas sujeitas a contestações e discussões, principalmente por se tratarem de verdades individuais. 
Esse conceito de verdade presente nas opiniões é um terreno que precisa ser mais bem definido, pois, para os usuários da língua, é possível presumir que uma opinião seja considerada "verdadeira" porque, em cada oportunidade de possível contestação, ela não foi refutada, ou ainda é possível utilizá-la como uma determinação, um fato estabelecido, quando não há qualquer legitimação da verdade.

A falta de contestação dos conceitos de verdade estabelecidos pode ser bastante prejudicial e causar atrasos em uma sociedade e, por vezes, consistir em ferramentas de poder e hegemonia social. Nessa direção, Dascal (2008:24), um dos representantes da Filosofia na contemporaneidade, ao dissertar acerca do imperialismo epistêmico, prática de massificação em sociedades em que os indivíduos têm a ilusão da autonomia, faz a seguinte afirmação a respeito do valor da diferença de opinião, do desacordo:

\footnotetext{
É preciso reconhecer o valor da discussão, da controvérsia, do desacordo, e não do acordo. Há muita ênfase sobre o acordo, a uniformidade do comportamento e das ideias. Existe uma pressão imensa sobre a uniformidade social, uma tentativa constante de convencer as pessoas, forçá-las a agir e pensar de certas formas desejáveis. Se houvesse essa uniformidade de uma maneira total, não haveria nenhum desenvolvimento do pensamento humano, nenhum progresso. Estaríamos na situação das sociedades tribais. Para sair dessa situação de colonização permanente das nossas mentes, devemos fomentar nossa capacidade natural de não estar de acordo.
}

Para que possamos pôr em prática nossa liberdade de expor e questionar opiniões, entrar em desacordo, buscar a contraposição de ideias e argumentos, entendemos que o debate se configura em um dos principais gêneros discursivos que permitem tal processo. 
Em um sentido amplo, o debate sobre as opiniões pode ser visto como o procedimento pelo qual os indivíduos decidem entre as alternativas que foram expressas e comparadas. Além de desempenhar um papel de grande responsabilidade na história e nas sociedades em que ocorreu, o debate apresenta constituição específica, permitindo desdobramentos e linhas teóricas, se não divergentes, complementares.

Em relação à estrutura do debate, alguns estudiosos já apresentaram reflexões em torno do processamento desse gênero; dentre eles destacamos Aquino $(1997)^{8}$ e Manosso (2003).

Ao entendermos o debate como uma divergência polêmica sobre as opiniões dos participantes, podemos observar uma espécie de "escala" na classificação das discussões polêmicas, conforme os estudos propostos pelos teóricos da Pragmadialética (Grootendorst, Henkemans e van Eemeren $(1987,1996))$. Ainda, devemos destacar os trabalhos de Dascal (1999; 2006), em que procura caracterizar a polêmica por meio de sua classificação tipológica.

\subsection{As diferenças de opinião}

O tratamento das diferenças de opinião marcou o trabalho de Grootendorst, Henkemans e van Eemeren (1996). Esses estudiosos caracterizam as diferentes escalas da discussão polêmica, ressaltando o fato

${ }^{8}$ Destaca-se a tese "Conversação e conflito - um estudo das estratégias discursivas em interações polêmicas", na qual a autora não só apresenta as orientações acerca da condução de uma interação polêmica, como oferece um estudo sobre a constituição desse gênero discursivo. 
de que ela ocorre em graus variados e observando que uma análise da argumentação deve se iniciar pela identificação e caracterização das principais diferenças de opinião.

A diferença de opinião pode apresentar a seguinte classificação, segundo os autores: a) elementar: ocorre no momento em que o ponto de vista de um indivíduo encontrar apenas a apresentação da dúvida de seu interlocutor; b) mista: se um dos interlocutores adotar e expressar um ponto de vista conflitante em relação à opinião inicial, e c) múltipla: caso o processo de expor as opiniões acabe por se relacionar a mais de uma proposição.

Destaca-se que, na análise dos eventos discursivos, podemos encontrar, dentre a classificação precedente, uma variedade de ocorrências que se constituem em uma das modalidades de polêmica que caracterizamos no item seguinte.

\subsection{A discordância e a discussão argumentativa}

Ao caracterizarmos a discordância e a discussão argumentativa observa-se uma distinção que deriva da natureza da interação. Sabe-se que as pessoas frequentemente discordam umas das outras; entretanto, segundo Grootendorst, Henkemans e Van Eemeren, (1996) dificilmente, ou em raras ocasiões, duas pessoas aceitam o fato de que suas opiniões são conflitantes e não se engajam em uma discussão argumentativa para transformá-las. Destaca-se que em alguns contextos, tal atitude seria insensata. Assim, como 
o modo de solucionar a diferença de opinião, os interlocutores discutem acerca de suas opiniões e tentam chegar a alguma espécie de acordo ${ }^{9}$.

A argumentação pode ser vista como uma forma de alcançar a solução dessa diferença de opinião, a qual passa, então, a ser denominada discussão argumentativa, que se caracteriza por visar, essencialmente, o alcance de um acordo razoável.

Nesse tipo de discussão, o papel da razoabilidade ${ }^{10}$ tem grande $^{2}$ importância e sua constituição parece procurar o seu direcionamento; entretanto, ao se argumentar pode-se prescindir de ser razoável, uma vez que determinados movimentos discursivos podem não ser auxiliares ao procedimento de resolver a diferença de opinião. Assim, apresenta-se a necessidade de uma análise cuidadosa para revelar os aspectos do discurso pertinentes e necessários a um julgamento acerca de sua razoabilidade. Acredita-se que seja tarefa daqueles que estudam a argumentação pesquisar profundamente as várias camadas do texto argumentativo, para que todos os elementos sejam levados em consideração.

Além dos estudos dos teóricos da Pragmadialética acerca dos eventos discursivos que se constituem em uma diferença de opinião, faz-se necessário observar aqueles que apresentam uma análise minuciosa acerca da polêmica,

\footnotetext{
9 Aquino (1997) ressalta que empreender a busca pelo acordo pode acarretar divergências de opiniões, já que a oposição de pontos de vista é constitutiva do discurso argumentativo, o que significa dizer que argumentar é também polemizar.

${ }_{10} \mathrm{O}$ conceito de razoabilidade na Pragmadialética centra-se na afirmação da inexistência da certeza, acarretando no ceticismo sobre determinado ponto de vista, independente de quem o fizer e do conteúdo a que se refere e tem relação com a instauração de um procedimento para resolver a diferença de opinião por meio da discussão crítica, processo intersubjetivo e relacionado ao contexto de sua ocorrência (VAN EEMEREN, 2004).
} 
seja em menor ou maior grau. Nesse sentido, os trabalhos de Dascal (1999/2005) são de grande referência, conforme destacamos a seguir.

\subsection{A tipologia da polêmica}

A opinião constitui-se, por excelência, o exercício da livre expressão dos indivíduos e pode-se transformar em um evento discursivo de maior ou menor grau de polêmica. Dascal (1999) apresenta "a tipologia geral das polêmicas" em que distingue três tipos idealizados dessas ocorrências: a discussão, a disputa e a controvérsia, cada qual tendo seu próprio objetivo e recurso para atingi-lo. Ainda, destaca que os debates ocorridos na contemporaneidade podem apresentar-se como uma combinação tipológica não-linear desses três tipos polêmicos.

Em relação à sua constituição, pode-se dizer que, na discussão, há uma preocupação dos participantes do evento discursivo com a verdade dos fatos, e para tal, a prova ou evidência são instrumentos que servem a esse fim específico. O autor ilustra tal afirmação com o seguinte exemplo: "dois matemáticos podem ter diferenças de opinião a respeito da demonstração de um teorema. Entretanto, se um deles mostrar que o outro cometeu um erro na sua demonstração, a questão fica decidida" (Dascal: 1999:19).

Dascal (2005) destaca que a discussão refere-se à forma idealizada de um debate científico, em que os participantes podem ser considerados racionais (no sentido de uso da razão) e a argumentação utilizada tem um caráter lógico, matemático e amparado na demonstração. 
De modo dicotômico, temos a disputa, na qual se busca a vitória sobre um adversário. Nesse tipo de polêmica, o estratagema configura-se um recurso para se sobrepor ao oponente, levando o auditório a acreditar que ele fora derrotado. Cada participante assume que o interlocutor está totalmente errado, enquanto ele está totalmente certo. Os movimentos discursivos que se apresentam, por vezes, direcionam à mudança de opinião sem qualquer razoabilidade. Uma intervenção externa, como um juiz em um tribunal ou um mediador em um debate político eleitoral, é o responsável pelo término do debate, sem qualquer modificação da opinião dos participantes.

Ainda, há a controvérsia, em que os interlocutores têm por meta o convencimento do auditório, utilizando-se de argumentos para esse fim. A controvérsia não apresenta uma constituição exata como a discussão, devido à dificuldade de se defini-la, e nem tão inconclusiva quanto a disputa, na qual só os meios importam.

A constituição do gênero debate pode se apresentar como uma mescla dessas três variedades. Tais mudanças tipológicas podem ser observadas, segundo o autor (2005), pela variação nos temas debatidos e pelas estratégias retóricas e argumentativas. Desse modo, a discussão pode tornar-se uma controvérsia quando os participantes questionarem as estimativas de cada um, ou uma disputa no momento em que eles tratarem da irracionalidade ou má-fé um do outro. Em consequência, o processo de conclusão do debate também sofre uma mudança: de modo geral, as discussões podem ser solucionadas, as disputas dissolvidas/extinguidas, enquanto as controvérsias podem, no máximo, ser passíveis de resolução. O autor destaca que a possibilidade de 
mudança tipológica demonstra que essas resoluções podem ser meramente temporárias.

Ainda, de modo a ilustrar a constituição de dois tipos comumente assumidos como componentes do gênero debate, Dascal (2005) apresenta a dicotomia entre o par disputa/discussão e destaca os elementos que sustentam tal dicotomia, conforme citamos a seguir ${ }^{11}$ :

\section{Discussão}

$A$ verdade

Questão pode ser decidida

Amparada pela Lógica

Racional

Debate sobre temas e tópicos

Produz mudança de opinião
Disputa

Minha verdade

Questão não pode ser decidida

Amparada pela Retórica

Irracional

Debate sobre atitudes

Entretanto, apesar de esses dois tipos polêmicos serem amplamente encontrados no contexto sóciodiscursivo relacionado à ocorrência do gênero debate, eles não são suficientes para exemplificar a variedade constitutiva do gênero em questão que se manifestam na atualidade. De modo a eliminar a

\footnotetext{
${ }^{11}$ Tradução nossa.
} 
dicotomia e estabelecer um tipo de polêmica que se configure de modo menos polarizado, o autor apresenta a controvérsia.

Nesse tipo de debate, o objetivo é persuasão racional e não a vitória como na disputa. No que se refere à discussão, observa-se que a controvérsia prescinde da necessidade da aplicação de um método aceito, incondicionalmente, para o alcance de resultados inquestionáveis, além de renunciar à busca da revelação da verdade.

Desse modo, não haveria mais uma dicotomia nos tipos que constituem os debates, e sim uma tríade, e ressalta que a "desdicotomização" do conceito pragmático aplicável às manifestações da linguagem pode ser uma alternativa altamente enriquecedora.

Ao encontro de tal afirmação, destacando a importância das pesquisas que versam sobre a estruturação e a condução de debates, e de modo a ilustrar a tipologia proposta, Dascal (2005) apresenta o quadro a seguir ${ }^{12}$ :

\begin{tabular}{|l|l|l|l|}
\hline & DISCUSSÃO & CONTROVERSIA & DISPUTA \\
\hline OBJETIVO & VERDADE & PERSUASÃO & VITÓRIA \\
\hline EXTENSÃO & LOCAL & GERAL & LOCAL \\
\hline PROCEDIMENTO & DECISÃO & QUESTIONAMENTO & NÃO INTERNO \\
\hline MOVE TÍPICO & PROVA & ARGUMENTO & ESTRATAGEMA \\
\hline ESTRATÉGIA & DICOTOMIA & DESDICOTOMIZAÇÃO & DICOTOMIA \\
\hline FINALIZAÇÃO & SOLUÇÃO & RESOLUÇÃO & DISSOLUÇÃO \\
\hline
\end{tabular}

Quadro 1- Constituição da tipologia das polêmicas (Dascal, 2005)

\footnotetext{
12 Tradução nossa.
} 
No quadro precedente, observa-se a constituição dos tipos de polêmica por meio da classificação dos itens que os compõem, de modo a instrumentalizar a definição dos eventos discursivos de acordo com o objetivo, a extensão, o procedimento adotado pelos interlocutores, os movimentos discursivos típicos, a estratégia e o resultado final estabelecido.

Conforme as definições precedentes de discussão, controvérsia e disputa, propostas por Dascal (op. cit.), parece-nos possível dizer que o gênero que configura nosso objeto de estudo, o debate político eleitoral, situa-se mais na tipologia referente à disputa, uma vez que os participantes do evento polêmico buscam a vitória sobre o seu interlocutor, amparam seus argumentos sobre o conceito de verdade individual e não promovem uma mudança na opinião colocada em pauta, principalmente, em relação ao antagonista/protagonista da disputa. Ressalva-se que a manutenção do ponto de vista do interlocutor pode não ser verdadeira, se tomarmos o auditório como o destinatário direto ${ }^{13}$ desse gênero discursivo.

A tipologia estabelecida por Dascal pode ser de grande valia, ao analisarmos eventos discursivos do campo da polêmica que apresentam uma configuração mista ou híbrida, mais próxima da definição de controvérsia. De todo modo, sua contribuição teórica ao campo dos estudos da argumentação, no qual se constitui nossa pesquisa, é de grande relevância e pode fornecer instrumentos auxiliares à análise dos mais diferentes gêneros discursivos.

A discussão polêmica, independente de qualquer questão tipológica, desempenha o papel de promover a competência crítica e argumentativa

\footnotetext{
${ }^{13}$ Conforme Fávero e Aquino (2003).
} 
indispensáveis à realização do próprio ideal de democracia, das sociedades que visam possibilitar aos indivíduos a igualdade social e cultural.

Para que os indivíduos possam ser considerados aptos a participar desse evento discursivo, eles precisam expressar suas opiniões e contestar as de seus interlocutores, seja de modo dicotômico, misto ou híbrido. Para esse fim, a manifestação e livre expressão da opinião constitui um objeto de suma importância, para que se conquiste $\mathrm{o}$ ideal de igualdade a partir das oportunidades de participação na vida em sociedade.

No domínio do processo de expor a opinião e argumentar, podemos observar a ocorrência de debates que alteram ou poderiam alterar a história dos povos. Segundo Lopes (2006, p.13):

As batalhas pelo convencimento ganham e perdem eleições, fazem vencer ou fracassar revoluções e estilos artísticos, mantêm ou transformam comportamentos de base sóciomoral. Portanto, é nesta arena que é jogado o futuro das nações, das artes, das culturas e da vida em suas várias dimensões. A luta pela democracia, com base em uma real justiça social, implica postular espaços de discussão no seio deste espaço das mídias. Não se pode aceitar passivamente que existam 'donos' da cultura e da opinião comum.

A existência de mecanismos que possibilitassem a liberdade de expressão política, filosófica e artística nos meios de comunicação de massa modernos reduziria, gradativamente, os casos em que a opinião comum se sedimentou nas tradições mais conservadoras, condenando a sociedade à apatia e os indivíduos a serem meros seguidores de uma espécie de regimento implícito. 
A preocupação com a liberdade de pensamento, manifestação das mais diversas opiniões e o consequente debate das ideias parece-nos amparar-se em um sentido de dialogismo inerente ao ato de utilização do discurso. Nessa direção, acreditamos ser necessário dissertar acerca da teoria que tem por base o caráter dialógico da linguagem, conforme passamos a observar nos estudos derivados do pensamento de Bakhtin, os quais abordamos a seguir.

\subsection{Uma concepção dialógica da linguagem}

Ao analisar as manifestações da linguagem a partir do processo interacional, ressaltando a relevância do dialogismo para a comunicação, Bakhtin (2003) reflete sobre a questão dos gêneros do discurso. A existência de enunciados caracterizados por uma relativa estabilidade, que torna possível o agrupamento de textos com propriedades afins, configura uma noção que percorre o pensamento ocidental há séculos. A grande contribuição de Bakhtin para a teoria dos gêneros reside, principalmente, na relação estabelecida entre os gêneros, a linguagem e a dinâmica das interações sociais.

Do ponto de vista da vida humana em sociedade, os diferentes campos de atividade demandam, para esse teórico, a utilização de enunciados específicos que atendam às diferentes situações de comunicação, tornando eficaz, de acordo com intencionalidades específicas, a interação entre sujeitos. Os vários enunciados produzidos nos processos comunicativos seguem, por sua vez, as coerções dos gêneros discursivos ligados às atividades humanas realizadas (BAKHTIN, 2003). 
A delimitação de um gênero discursivo, segundo essa teoria, leva em conta três aspectos fundamentais que permitem o agrupamento dos textos: a relativa estabilidade dos enunciados é garantida por meio de estruturas composicionais, da temática e de estilos semelhantes. Desse modo, uma forma organizacional comum, uma mesma esfera discursiva e um modo de presença característico do sujeito enunciador configuram um determinado gênero discursivo.

Bakhtin afirma que os gêneros discursivos passam continuamente por alterações. As mudanças verificáveis ao longo da trajetória histórica de um gênero estão ligadas às transformações pelas quais a sociedade passa. Os gêneros, dessa forma, devem ser compreendidos à luz dos planos espacial e temporal, uma vez que refletem as práticas comunicativas mantidas entre sujeitos cultural e historicamente situados.

No âmbito das relações entre os gêneros, o tempo e o espaço, verificase que os discursos carregam consigo as vozes de discursos anteriormente produzidos, com as quais concordam ou discordam. Sob a perspectiva dialógica da linguagem, todo enunciado pode ser entendido como uma resposta - ainda que indireta - a enunciados com os quais concorda ou discorda.

Segundo Bakhtin (2003), os enunciados constituem, entre si, uma rede em que podem ser identificadas muitas vozes diferentes. Do mesmo modo que todo texto produzido reforça pontos de vista já presentes em textos anteriores a ele, um texto também se contrapõe a outros que veicularam discursos avessos ao seu. Se houvesse consenso a respeito de todos os assuntos, não haveria 
necessidade de produção de novos textos ou de discussões de ideias. $\mathbf{0}$ terreno onde residem os discursos baseia-se sempre na polêmica e na multiplicidade de visões.

Tal comportamento pressupõe o envolvimento dos sujeitos, seja em uma interação face a face ou não, como no caso do auditório do debate político eleitoral, o qual, apesar de apresentar uma espécie de distanciamento da ocorrência da interação, acaba por participar dela e não consegue ficar imune ao seu acontecimento. Isso decorre do fato de que, à medida que se envolve emocionalmente, sinalizando aprovação, desaprovação ou, no mínimo, refletindo acerca do tópico em questão, os interlocutores que compõem o auditório tomam parte do processo de interação, assumindo uma atitude responsiva.

Assim, podemos compreender que a concepção de gênero desse autor encontra-se, de determinada maneira, ligada à noção de certa estabilidade que nos permite reconhecê-lo e agir de acordo com as sanções ou opções relacionadas àquela determinada atividade humana. Pelo exposto, entendemos que o conceito de gênero proposto por Bakhtin poderá dar-nos o alicerce necessário para caracterizarmos o objeto de nossa pesquisa, o debate político eleitoral.

A razão de selecionarmos como objeto de observação o debate político eleitoral ampara-se em nossos questionamentos acerca de sua caracterização como um gênero único e específico, mas que apresenta certa similaridade com outros pertencentes à mesma esfera discursiva. 
Entendemos que essa afirmação é possível em razão da especificidade da esfera a que pertence e de sua, aparentemente estável, estrutura composicional. O primeiro conceito, a esfera, pode ser o elemento responsável pela definição de um gênero discursivo, o qual pode adquirir características próprias de acordo com a esfera em que está inserido, e assim, em nosso trabalho propõe-se a caracterização do debate político eleitoral como um gênero discursivo que se encontra inserido na esfera do discurso político interrelacionada à da mídia.

Tal noção de esfera discursiva é o fator determinante para que o debate, gênero em questão, apresente um formato específico. Dentre essas especificidades, selecionamos aquela em que os participantes discutem acerca de um tópico proposto por um mediador (em forma de pergunta) e que será veiculada pela mídia a partir de determinado meio de comunicação.

As possíveis atitudes responsivas desses participantes do debate, os seus enunciados ou atos de fala devem estar adequados à esfera ou o campo, conforme salienta Grillo (2006, p.146):

(...) a noção de esfera permeia a caracterização do enunciado e dos seus tipos estáveis, os gêneros, no que diz respeito ao seu tema, à sua relação com os elos precedentes (enunciados anteriores) e com os elos subseqüentes (a atitude responsiva dos co-enunciadores).

Já no que se refere à atitude responsiva dos co-enunciadores, podemos dizer que por meio da esfera discursiva em que ocorre o debate, é possível conceber previamente uma imagem do público, a respeito de seus gostos, suas 
posições sociais e políticas, suas possíveis dúvidas e procurar adequar os assuntos debatidos a essa identidade.

De acordo com essa proposta teórica, para a delimitação de um gênero, deve-se atentar às influências e coerções decorrentes da esfera ou campo da atividade humana intrínsecas ao gênero em questão, o debate político eleitoral, já que todo enunciado é direcionado a alguém, é endereçado ao outro, a um sujeito que se constitui, também, pelas interferências e pela constituição da esfera discursiva, conforme Bakhtin (op. cit., p. 301):

Um traço essencial (constitutivo) do enunciado é o seu
direcionamento a alguém, o seu endereçamento. (...) o
enunciado tem autor (e, respectivamente, expressão, do que já
falamos) e destinatário. Este destinatário pode ser um
participante-interlocutor direto do diálogo cotidiano, pode ser
uma coletividade diferenciada de especialistas de algum campo
especial da comunicação cultural, pode ser um público mais ou
menos diferenciado, um povo, os contemporâneos (...) todas
essas modalidades e concepções do destinatário são
determinadas pelo campo da atividade humana e da vida a
que tal enunciado se refere. A quem se destina o enunciado,
como o falante percebe e representa para si os seus
destinatários, qual é a força e a influência deles no enunciado -
disto dependem tanto a composição quanto,
particularmente, o estilo do enunciado. ${ }^{14}$ Cada gênero do
discurso em cada campo da comunicação discursiva tem sua
concepção típica de destinatário que o determina como gênero.

O participante de um evento discursivo que constitui um gênero dotado de intensa carga polêmica deve levar em conta a natureza do auditório (seja ele real ou virtual, caracterizado pela imediatez ou não, qual é o público em geral e o público pretendido), sua constituição social (classe social, profissão, situação financeira etc.) e quais as possíveis atitudes responsivas ao evento

\footnotetext{
${ }^{14}$ Grifos nossos.
} 
em si (compreensão do tópico, conhecimentos especializados sobre o tema, pontos de vista etc.), para que possa antecipar as possíveis respostas.

A noção de esfera proposta por Bakhtin (op. cit.) tem relação profunda com o gênero discursivo e poderíamos dizer que é impossível observá-lo sem levar em conta esse conceito. Nosso trabalho ampara-se na ideia de que um gênero forma-se na inter-relação entre as esferas sociais estabilizadas e no contexto único da enunciação, de que eles possuem uma espécie de formato ou forma relativamente fixa e que não são criados a cada novo ato de fala, os quais poderão ser responsáveis (se assim for o caso) pela possível transmutação de um gênero; entretanto, o que constitui, origina e fixa um gênero enquanto prática discursiva são as esferas de atividade humana, pois elas atuam historicamente como sedimentadoras de determinadas práticas.

Ainda, ao caracterizarmos o debate, faz-se necessária uma análise em relação à forma (ou estrutura) composicional, outro conceito abordado em Bakhtin (1993, p. 25) e que merece atenção ao caracterizarmos um gênero discursivo:

As formas composicionais que organizam o material têm um caráter teleológico, utilitário, como que inquieto, e estão sujeitas a uma avaliação puramente técnica, para determinar quão adequadamente realizam a tarefa arquitetônica. A forma arquitetônica determina a escolha da forma composicional: (....)

De acordo com a proposta bakhtiniana, a forma composicional, no caso de nosso trabalho, do debate, apresenta certa estabilidade, para que se constitua em um gênero reconhecível pelos interlocutores. Historicamente, tal formatação obedece a certos padrões e normas decorrentes da vida em 
sociedade. Observa-se que muitas culturas desenvolveram sistemas de debate organizados, sendo que esta organização pode ocorrer de acordo com as diferentes ocasiões planejadas, ou seja, torna-se possível designar seus participantes, escolher o assunto em discussão de uma forma específica, conduzi-lo de modo a obedecer a um formato determinado e com os mais variados princípios (quem pergunta, responde ou contra-argumenta), conforme se constata pela observação da história do debate no mundo (Branham, 1991).

As influências e coerções decorrentes da esfera discursiva que permeiam a estrutura composicional, como a definição de quais assuntos podem ser levados a debate, as restrições e os participantes autorizados a fazer parte deles (pelos organizadores destes debates) promove um entendimento claro e valioso sobre a natureza e constituição das sociedades e da época em que tiveram lugar, além de nos esclarecer a respeito da atual conjuntura e prática do debate moderno, amplamente influenciadas por esses fatores.

Assim, além de desempenhar um papel de grande responsabilidade na história e nas sociedades em que ocorreu, o debate apresenta constituição específica, que o identifica, que o torna reconhecível enquanto gênero discursivo.

Dessa forma, a esfera ou campo são determinantes para a constituição do gênero do discurso; entretanto, convém ressaltar que o estudo sobre os gêneros discursivos nos permite observar as diferentes características e identidades relativas a cada campo ou esfera da comunicação humana. 
Em relação a esse conceito, nosso estudo insere-se na esfera do discurso político, inter-relacionada com a da mídia, da qual trataremos a seguir e, nesse campo, constitui-se um gênero que pode ser nomeado de debate político eleitoral.

\subsection{A esfera do discurso midiático}

Conforme já dito anteriormente, cada campo/esfera de atuação humana apresenta determinadas especificidades e coerções que definem e delimitam o gênero discursivo.

A esfera midiática, conforme os estudos de Charaudeau (2006, p. 24), apresenta uma constituição que constrói o sentido por meio da troca entre duas instâncias: de produção e de recepção daquilo que o autor chama de "máquina midiática":

Isso determina três lugares de pertinência: o da instância de produção, submetida a certas condições de produção; o da instância de recepção, submetida a certas condições de interpretação; o do texto como produto, que se acha, enquanto tal, submetido a certas condições de construção (....) a primeira instância é representada pelo produtor da informação (o organismo de informação e seus atores), a instância de recepção pelo consumidor da informação (diferentes públicos: leitores, ouvintes, telespectadores) e o produto pelo texto midiático (artigo de jornal, boletim radiofônico, telejornal, etc.)

De acordo com o autor, determinadas características de tal esfera acabam por caracterizar as representações sociais do potencial público de determinada máquina midiática, a qual, por vezes, considera o auditório sem basear-se em seu desejo de conhecimento/informação, e sim se amparando 
em comportamentos comerciais que pretendem conquistá-lo não como destinatários ou interlocutores, mas como consumidores de determinado formato ou produto.

Outro conceito abordado por Charaudeau (2006, p. 49) e que nos interessa refere-se ao "efeito de verdade". Essa noção depende da subjetividade do eu em sua relação com o mundo, partilhando uma concepção do que pode ser julgado como verdadeiro por ser compartilhável com os outros. Tal efeito ampara-se na convicção, diferentemente do valor de verdade que se baseia na evidência, e se prende a uma espécie de:

(...) dispositivo enunciativo de influência psicossocial, no qual cada um dos parceiros da troca verbal tenta fazer com que 0 outro de sua adesão a seu universo de pensamento e de verdade. O que está em causa aqui não é tanto a busca de uma verdade em si, mas a busca da credibilidade, isto é, aquilo que determina o "direito à palavra" dos seres que comunicam $e$ as condições de validade da palavra emitida.

Não podemos deixar de observar uma confluência nessa concepção de efeito de verdade com o objeto de nossa análise. No gênero em questão, o debate político eleitoral (televisivo), essa noção parece ser a essência do discurso dos interlocutores. Ao expressarem suas opiniões, os participantes do debate, muitas vezes, não se amparam em evidências, mas parecem agir com tal convicção que seus atos de fala atingem um status de efeito de verdade, atribuindo credibilidade ao interlocutor e, desse modo, persuadem ou convencem o auditório. 
No que se refere ao corpus do nosso trabalho, o autor apresenta uma definição que considera o debate um gênero baseado em eixos tipológicos ${ }^{15}$ caracterizado pela presença de uma série de convidados e de um mediador que tratam de determinado tema, completamente organizado e gerenciado pela instância midiática.

Ressalta ainda que a mídia, principalmente a televisão, não pode ser mais taxada como "ópio do povo", pois cumpre um papel social ao relatar os acontecimentos no mundo, explicando suas possíveis consequências, e propiciando o debate, ainda que possa incorrer em erros e desvios: “(....) Mais uma vez, é a máquina de informar que está em causa, por ser ao mesmo tempo poderosa e frágil, agente manipulador e paciente manipulado." (CHARAUDEAU, 2006, p. 253).

O poder que a mídia ostenta parece ser diminuído com a afirmação precedente, o que nos leva a direcionar determinada responsabilidade para a figura do cidadão, daquele indivíduo que é influenciado e influenciador da instância midiática. Pode-se dizer que a televisão (ou qualquer outro suporte da esfera midiática) procura orientar seu conteúdo programático para aquilo que será do interesse do público-alvo. Desse modo, não podemos culpar, exclusivamente, os canais midiáticos pela espetacularização de determinado acontecimento veiculado. A qualidade ou veracidade podem decorrer da instância de recepção, a qual consome ou não, determinando o sucesso comercial do produto em questão.

${ }^{15}$ Conforme a terminologia do autor. 
Podemos atribuir determinada culpabilidade à consciência cidadã, que opta por atribuir, exclusivamente, a responsabilidade de instância manipuladora à mídia, eximindo-se de qualquer ação enquanto agente transformador da realidade social em que está inserida.

Como dissemos anteriormente, nosso estudo propõe-se a observar a constituição do debate político eleitoral; entretanto, esse gênero, subordinado à esfera do discurso político, encontra-se veiculado pela mídia televisiva, o que nos leva a atentar para uma espécie de inter-relação ou intersecção dessa esfera com a midiática.

Rubim (2000) destaca o papel da modernidade como agente transformador da prática política, que em seu início promovia por meio da Retórica Política Grega uma discussão para esclarecer as ideias e opiniões. $\mathrm{Na}$ atualidade, o campo da comunicação constitui-se como "esfera de poder especializado" que se associa a quatro novas modalidades: mídia, lógica capitalista, campo social e rede.

O suporte que ampara o debate político eleitoral, a televisão, teria como papel social, além de promover um evento discursivo que propaga a democracia, a função de um símbolo fiscalizador que defende, além de buscar, os interesses da população, aumentando seu poder enquanto máquina de influência.

Passeti e Silveira (2010, p. 82) destacam que

No espaço fechado do cenário político-midiático tradicional, o funcionamento discursivo apresentava, de um lado, os discursos políticos, caracterizados como específicos dos sujeitos da esfera política e, de outro lado, os discursos 
midiáticos, cuja prática discursiva se destaca no âmbito político por sua capacidade de "intermediar" o contato entre os sujeitos da esfera pública, ou da política, e os cidadãos comuns, sendo que, nesse cenário, os cidadãos comuns exerciam o papel de receptores passivos dos discursos políticos e midiáticos.

Essa inter-relação de esferas (política e mídia) produziu alguns efeitos que modificaram o cerne do discurso político, o qual, na atualidade, cede aos apelos do mercado de consumo e serve à fabricação da imagem dos políticos.

Tal apelo midiático, decorrente do suporte que propaga ou veicula o evento discursivo, atribui certas especificidades ao discurso dos interlocutores. De acordo com o objeto de nossa análise e o suporte em que ele é transmitido (a televisão), torna-se possível observar que o sujeito político modifica seu discurso. Isso é comprovado com a afirmação de Santos e Romualdo (2010, p. 131):

Diante da lente televisiva, capaz de expandir ao grau máximo cada movimento, o político abrandou sua voz, diminuiu a bruscalidade de seus gestos, criou logotipos e passou a sorrir mais. A capacidade de registrar cada atitude, de gravar e de transmitir para um número infinitamente maior de espectadores que os dos comícios fez com que a mídia televisiva impulsionasse os políticos a buscarem maior domínio de suas emoções e uma habilidade em tornar natural toda simpatia e todo recato. (...)

Essa caracterização parece-nos estar de acordo com o padrão dos eventos políticos televisionados, principalmente, as "propagandas políticopartidárias obrigatórias", que são programas de televisão e rádio veiculados à época das eleições e que consistem em eventos midiáticos completamente produzidos e que pretendem construir a imagem dos candidatos. 
Desse modo, podemos dizer que a esfera midiática atribui ao discurso político uma espécie de espetacularização, a qual, conforme o conceito proposto por Rubim (2004, p. 20), "forjada ou não pela mídia, nomeia o processamento, o enquadramento e a reconfiguração de um evento, através de inúmeros expedientes". Isso nos leva a refletir sobre o quanto os sujeitos envolvidos em um evento polêmico - como aquele que compõe o nosso corpus - adaptam suas mensagens, opiniões e estratégias a esse processo de produzir um espetáculo.

De acordo com o até aqui exposto, pudemos observar que as especificidades da esfera midiática atribuem ao debate político eleitoral veiculado pela mídia televisiva características que o definem e transformam. Desse modo, faz-se necessário compreender, também, os traços distintivos da esfera política que determinam e demarcam a constituição do gênero em estudo.

\subsection{A esfera do discurso político}

Para tratar das especificidades dessa esfera de atuação humana, recorremos aos estudos de Charaudeau (2006), o qual, ao tratar do discurso político, salienta que ele configura, a priori, um modo de se chegar a determinado objetivo, colocado a serviço da imagem pessoal. Segundo o autor (2006, p.19):

(...) o poder comunicativo remete à busca pela dominação legítima (...). Isso faz com que ao espaço de discussão que determina os valores responda um espaço de persuasão no qual a instância política, jogando com argumentos da razão e 
da paixão, tenta fazer a instância cidadã aderir à sua ação. Todos os grandes políticos disseram, ou deram a entender, que a arte política reside em uma boa gestão das paixões coletivas, isto é, em um "sentir com os outros" que, é preciso acrescentar, os torna cegos quanto às suas próprias opiniões e motivações pessoais.

De acordo com o objetivo e a intencionalidade, o discurso político utilizase da argumentação para servir ao propósito dos participantes e buscar conquistar a adesão dos interlocutores ou, segundo a terminologia proposta por Perelman e Olbrechts-Tyteca, do auditório.

Ainda segundo Charaudeau (op. cit), a definição da argumentação utilizada no discurso político apresenta a ocorrência de palavras vazias, falsas e que não representam a verdade de seu enunciador. O discurso político é, por excelência, o lugar de um "jogo de máscaras". Toda palavra pronunciada no campo político deve ser tomada ao mesmo tempo pelo que ela diz e não diz. Jamais deve ser tomada ao pé da letra, mas como resultado de uma estratégia cujo enunciador nem sempre é soberano.

O discurso político, para esse teórico, constitui-se em uma ligação entre a linguagem e a ação. A carga semântica do termo político reflete uma verdade do dizer (palavras de ação) e uma verdade do fazer (palavras que pretendem persuadir). No discurso, inscrevem-se a opinião e a verdade em uma "relação dialética entre a construção da opinião, na qual desemboca o julgamento reflexivo, e a verdade, que surge da ação e do ato de decisão" (CHARAUDEAU, 2006, p. 40).

Essa interação acontece nas comunidades que tenham uma forma de pensar e agir em comum, a qual medeia socialmente os valores fundadores do 
julgamento e da consequente ação que são transmitidos por meio do discurso e consolidados de modo a formar uma identidade.

O discurso político abrange tudo aquilo que se relaciona com a vida em sociedade e a administração da esfera pública; uma divisão de um mesmo ideal de sociedade entre a instância pública e a do cidadão. Para Charaudeau (2006, p. 46):

A política é um campo de batalha em que se trava uma guerra simbólica para estabelecer relações de dominação ou pactos de convenção. Consequentemente, o discurso das idéias se constrói mediante o discurso do poder, o primeiro pertencendo a uma problemática da verdade (dizer o Verdadeiro) e o segundo a uma do verossímil (dizer ao mesmo tempo o Verdadeiro, o Falso e o Possível).

Ainda, pode-se dizer que o autor reflete muito acerca do papel dos políticos enquanto atores, aqueles que "parecem ser", criando a metáfora do palco teatral. Aqueles que fazem uso do discurso político procuram despertar o afeto de seus interlocutores por meio do "mentir verdadeiro", uma estratégia retórica que pretende conseguir a adesão do auditório, seja omitindo, seja modificando a verdade: "todo político sabe que Ihe é impossível dizer tudo, a todo momento, e dizer as coisas exatamente como ele as pensa ou concebe, pois suas palavras não devem atrapalhar sua ação" (op. cit., p. 104-105).

Encontramos nos trabalhos de Charaudeau (op. cit. 81-82), uma convergência em relação ao que é apregoado pela Pragmadialética a respeito da distinção nos mecanismos cognitivos envolvidos nos atos de convencer e persuadir e o consequente campo semântico implicado: 
A primeira pertenceria ao puro raciocínio, fundar-se-ia sobre as faculdades intelectuais e estaria voltada para 0 estabelecimento da verdade. A segunda pertenceria aos sentimentos (hoje em dia, diríamos "ao afeto"), fundar-se-ia sobre os deslocamentos emocionais e estaria voltada para 0 auditório (...) O que permanece em discussão é a questão de saber se essas categorias convicção/persuasão existem e agem independentemente umas das outras ou se elas estão ligadas por uma relação, de tal forma estreita, que seria difícil fazer a separação entre o que pertenceria a uma e o que pertenceria à outra; correlativamente, pode-se perguntar qual é a parte que cada uma assume na encenação do discurso (...) .

Assim, pode-se observar que essa dicotomia entre os dois processos discursivos/cognitivos de convencer/persuadir desperta questionamentos nos teóricos que pesquisam os elementos envolvidos no ato de influenciar o outro por meio da argumentação.

Charaudeau chama atenção para o fato de que os políticos, enquanto atores em um palco, preocupam-se muito com o ethos (enquanto recurso para fabricar imagens de líder fidedigno e sedutor) e o pathos (como uma espécie de dramatização da cena pública), utilizando-se recursos e estratégias, esquecendo-se de avaliar criticamente seus interlocutores, desacreditando sua capacidade de julgar razoavelmente as opiniões em julgamento, (2006, p. 306):

Se quiserem exercer qualquer forma de influência sobre os cidadãos, os políticos desse mundo moderno do cartaz e do espetáculo devem aprender novas regras da insinceridade e do mentir verdadeiro legítimos, aceitar esse paradoxo moderno que quer que se conceda uma grande importância ao parecer, em uma época em que a cidadania é, além disso, mais esclarecida.

Essa afirmação vem ao encontro do que é estabelecido pela Pragmadialética, a qual apregoa a criticidade dos interlocutores e sua condição 
de juízes racionais que estão aptos a julgar de modo razoável, o que não exclui a necessidade de se observar a realidade sociocultural em que o evento discursivo ocorre, para que a análise seja credenciada e validada.

Tal preocupação com o contexto em que a argumentação ocorre ${ }^{16}$, especificamente em relação ao seu propósito, também foi alvo da atenção de Osakabe ([1979] /2002), ao afirmar que as significações derivadas das relações entre os protagonistas do discurso e da situação não podem ser preteridas em uma análise interpretativa. O autor (2002, p. 60), ao tratar dos atos de fala presentes em um evento discursivo, salienta que:

Ao contrário do que afirma Austin, o ato perlocucionário é também convencional na medida em que se subordina a determinadas regras contextuais. Antecipando um pouco a discussão, a distinção entre um ato de persuadir e um ato de convencer só pode ser feita se pensada numa distinção de contextos e não apenas numa distinção entre os meios de conduzir o ouvinte à aceitação de determinada posição.

Por meio dessa citação, observamos certa semelhança no pensamento do autor com os preceitos da Pragmadialética, a qual se preocupa com a definição dos atos de fala para ressaltar a influência do contexto e das relações sociais, pois apregoam que sua funcionalidade é determinada pelo contexto (verbal e não-verbal) em que estão inseridos e sua força ilocucionária depende do lugar que ocupam nesse contexto em que são performados. Como exemplo, temos o ato de fala declarativo, que requer uma determinada posição de autoridade por parte de quem o profere.

\footnotetext{
${ }^{16}$ No que diz respeito a essa relação com o contexto, destacam-se, ainda, os trabalhos de Aquino (1997, 2004, 2005, 2009).
} 
Ainda, a distinção entre os atos de convencer e persuadir também é alvo das pesquisas da Pragmadialética, a qual associa o primeiro ato ao modo de proceder na argumentação derivada dos estudos racionais e normativos e, o segundo, ao procedimento analisado pelos teóricos que amparam suas pesquisas nos preceitos da Retórica e da Nova Retórica.

Salienta-se que tal distinção, ao encontro do que afirma Osakabe (op. cit.), caracteriza-se de menor importância, se não entendermos os atos de fala como inter-relacionados ao contexto e ao campo discursivo em que ocorrem. Para esse autor, as regras de comportamento social, convencionais, e relativas ao contexto são os determinantes na escolha de um discurso que objetive persuadir e não convencer o seu auditório ou vice-versa, observáveis empiricamente.

Nosso trabalho, que tem por objetivo observar, na esfera do discurso político inter-relacionada com a esfera midiática, o gênero que se configura como debate político eleitoral, não pode prescindir da consideração dos elementos contextuais (verbais e não-verbais) que influenciam a performação e compreensão dos atos de fala presentes em tal evento discursivo, dotado de intensa carga polêmica, e que constituem a estrutura ou forma do gênero, reconhecível pelos interlocutores.

Os elementos que se configuram como os responsáveis pela forma e constituição do debate político eleitoral, gênero discursivo que consiste no corpus de nosso trabalho, merecem ser observados de modo detalhado, conforme procedemos a seguir. 


\subsection{A constituição do debate político eleitoral}

Ao observarmos o discurso político, encontramos a realização de uma das suas manifestações mais marcantes e polêmicas: o debate político em época eleitoral, o qual apresenta constituição específica. Amparamo-nos na perspectiva bakhtiniana para traçarmos a estrutura do debate político eleitoral: os gêneros discursivos passam continuamente por alterações e as mudanças verificáveis ao longo da trajetória histórica de um gênero estão ligadas às transformações pelas quais a sociedade passa.

Tal afirmação parece-nos propiciar a aproximação do gênero que compõe o nosso objeto de estudo com o gênero amplamente estudado por Aquino (2005): o debate político televisivo, que se encontra inserido na esfera do discurso da mídia e, por conta disso, apresenta determinadas especificidades similares ao debate político eleitoral, o qual também apresenta influências e coerções decorrentes dessa esfera.

Charaudeau (2006), ao caracterizar o debate atribui à instância midiática a regulação de tal evento discursivo, representada pela figura do animador (em nosso trabalho, o mediador) que desempenha o papel de "gestor da palavra": perguntando, dando o direito de resposta, fazendo intervenções e/ou esclarecendo um ato de fala de acusação ou de ordem. Esse autor (op. cit., p. 220) destaca que

(....) o animador se acha preso, por sua vez, nas exigências de seu papel, na medida em que o quadro de questionamento que deve desenvolver é o oposto da representação idealizada do questionamento que ajudaria o cidadão a melhor compreender 
os fenômenos sociais: ele está mais voltado para a criação de uma cena polêmica (...)

O papel do mediador em um debate também foi abordado por Doury (1995), que o destaca como a instância de regulação externa e como a figura mais importante nesse evento discursivo. Esse papel social tem por função: desenvolver o debate de acordo com o tema selecionado, deixar claras as regras do debate, gerir os turnos de fala de acordo com o tempo disponível, manter a polêmica em níveis aceitáveis e esclarecer possíveis dúvidas por ele atribuídas ao público.

Essa autora acredita que o mediador desempenha um papel dominante no debate televisivo, já que sua autoridade é reconhecida pelos participantes, pois "Ele é o mestre do jogo, o detentor das regras gerais que regem os debates televisivos". ${ }^{17}$ (DOURY, 1995, p. 246).

No que se refere à essência do debate ou a razão de sua ocorrência, observa-se que Charaudeau (2006) estabelece que um debate televisionado configuraria uma oportunidade de os participantes encenarem visualmente um evento discursivo, pois a assunção de que os telespectadores são o público a quem eles se dirigem, os leva a modificarem seus discursos de tal modo que o debate constituir-se-ia em uma espécie de máquina de espetáculo e não uma oportunidade de informar e propiciar conhecimento ao cidadão.

Estudos que observam o debate veiculado por uma instância midiática, propiciando uma espetacularização da polêmica, também foram desenvolvidos

\footnotetext{
${ }^{17}$ Tradução nossa de: “(...) C"est lui le «maître du jeu», le dépositaire des règles générales qui régissent les débats télévisés (...)".
} 
por pesquisadores brasileiros. Em especial, Aquino (2005, p. 172) ao tratar do gênero debate político televisivo caracteriza-o da seguinte maneira:

Ao relacionar o debate à mídia, entendemos que, dependendo do contexto, pode-se presenciar uma verdadeira luta ou embate, especialmente se ocorrer em época eleitoral em que a adversidade entre os participantes é bem explícita em razão do objetivo do encontro, isto é, da necessidade de vencer o debate para garantir a conquista dos votos.

Essa atitude de demonstrar coragem para se expor e para impressionar os adversários, além do público alvo, é frequentemente encontrada no debate político eleitoral, conforme ressaltado pela autora. Os participantes obedecem à regulação da estrutura composicional do gênero que é reconhecida pelos sujeitos e exposta pela autoridade cerceadora e reguladora: o mediador.

No que se refere à estrutura composicional do debate político eleitoral, pode-se afirmar que ela encontra determinada estabilidade: é um formato de certo modo fechado, sempre com a presença de um mediador e dos participantes do debate, os quais são candidatos a um cargo público e concorrem à eleição responsável pela realização do debate.

A configuração estrutura-se em blocos constituídos por perguntas, respostas, réplicas e tréplicas (em alguns casos) mediadas pelo apresentador e, em algumas circunstâncias, devido a ofensas ou acusações explícitas, do direito de resposta.

Conforme o exposto por Aquino (2005), as condições de funcionamento do debate (regras, tempo e protocolo) são combinadas de modo antecipado para facilitar a interação e a dinâmica discursiva. Essa dinâmica entre os 
participantes/interlocutores tem por objetivo ou uma busca pelo acordo (o que não se verifica no debate político eleitoral) ou fazer vencer uma determinada posição/opinião apresentada por um dos participantes.

Tal definição acerca das condições de funcionamento do debate, uma espécie de constituição formal, parece apresentar certa semelhança com o conceito de um dos estágios da discussão crítica, a abertura $^{18}$, na qual os participantes aceitam as regras da discussão crítica, assumem seus papéis de antagonista e protagonista e determinam as condições para a realização do evento argumentativo.

Ainda, os atos de fala que ocorrem na realização da polêmica constituem outro aspecto de similaridade com a Pragmadialética. Segundo Aquino (op. cit, p. 174), as perguntas e respostas podem ocultar outra função (outras modalidades de atos de fala):

\begin{abstract}
Essa dinâmica, por sua vez, pode ser detectada entre outros, pela localização de pares adjacentes, mais especificamente representados por perguntas e respostas, que podem funcionar como pedido de informação e, conjuntamente, apontarem para outra função que pode não se explicitar linguisticamente. Esses pares podem ocorrer, ainda, em réplicas e tréplicas. Outros pares, tais como, acusação/acusação, acusação/explicação, ofensa/ofensa, ofensa/desculpas etc, podem ser localizadostudo depende das limitações impostas pelo mediador que acaba, de algum modo, por demarcar a configuração do evento.
\end{abstract}

De acordo com o exposto pela autora, verifica-se que os atos de fala fazem-se presentes no debate político de modo a direcionar um efeito de sentido "pretendido", efetivamente, pelos participantes, enquanto determinados

\footnotetext{
${ }^{18}$ Apresentamos esse conceito no segundo capítulo de nosso trabalho.
} 
participantes procuram executar os atos de fala de modo que o auditório seja convencido e possa aderir à opinião por eles expressa, frequentemente, optando por um dos lados (participante).

A performação de determinados atos de fala em um evento polêmico como o debate político eleitoral, pode significar a realização de ataques pessoais repletos de uma carga emocional, por vezes exasperada, distante de pretender testar as opiniões dos interlocutores, e sim expor, negativamente, a face ${ }^{19}$ daqueles que se caracterizam como adversários.

Nesse gênero discursivo, nota-se que os participantes preocupam-se com o público eleitor, aquele a quem o evento é direcionado, ou seja o auditório. De acordo com a afirmação de Fávero e Aquino (2002: 175) ao analisarem o debate televisivo, especificamente o debate político: “(....) $\circ$ público, ainda que não esteja presente no contexto situacional e seja tomado como destinatário indireto, é, na verdade, um destinatário direto, por ser a própria razão da ocorrência do debate".

Essas autoras realizam um estudo acerca das estratégias argumentativas utilizadas pelos participantes do debate político e observam que a discordância nas posições dos debatedores acaba por suscitar a técnica da acusação, na qual os oponentes buscam expor publicamente a face negativa de seu adversário, em uma tentativa de conseguir a adesão do espectador.

\footnotetext{
${ }^{19}$ Conceito relativo à teoria das faces formulada por Goffman (1974/1981) e Brown \& Levinson (1987) e utilizada por Aquino (op. cit.).
} 
Destacam, porém, que a agressividade excessiva acaba por causar uma impressão negativa junto ao público, revelando, assim, que uma técnica argumentativa, ou uma falácia, pode ser positiva ou negativa dependendo do modo de utilização ou do contexto situacional.

Esse movimento discursivo ou técnica do agir argumentativamente tem grande presença em um debate, conforme destacado por Cicourel (1992) e referendado por Aquino (2005), que aplicou o conceito no debate político em nosso contexto. Aquele estudioso salienta a ocorrência bastante comum da realização de manobras para vencer um debate, tentando "controlar o significado do que é dito e tentam fazer seus enunciados parecerem verdadeiros e os de seus oponentes falsos, mudando o contexto e, automaticamente, mudando o enquadre". 20

Tal citação permite-nos observar que as manobras executadas pelos participantes do debate constituem um tópico significativo para o autor, mas que não recebe o nome de falácias; entretanto, parece-nos que se trata da mesma constituição e possui as mesmas características destas.

Em nosso trabalho, procuramos salientar a ideia de que, na realização dos debates políticos eleitorais entre os candidatos ao governo de um munícipio, estado ou nação, o principal intuito dos participantes e dos realizadores deveria consistir em oportunizar ao cidadão a possibilidade de refletir e formar opinião sobre os planos e plataformas políticas dos participantes; entretanto, na prática, os eleitores, por vezes, podem confundir-

\footnotetext{
${ }^{20} \mathrm{O}$ conceito de enquadre refere-se ao modo como o interlocutor organiza o discurso e orienta os participantes em relação à situação interacional (GOFFMAN, 1974).
} 
se entre as diversas táticas e estratégias utilizadas pelos políticos que querem, muitas vezes, salientar os defeitos e incoerências de seus oponentes.

Os participantes acreditam que, agindo desse modo, caracterizam a si próprios como candidatos combatentes e corajososos; em contrapartida, esquecem-se de que o auditório é composto, entre outros, por seres atentos e racionais, que buscam equilíbrio ou mudanças no modo de ser e agir daqueles que conduzem os rumos da política nacional, e o tipo de comportamento apresentado pelos participantes do debate pode promover a apreensão de determinadas imagens que não, necessariamente, apresentem características adequadas.

Conforme expusemos, a manifestação de um evento discursivo dotado de polêmica configura um lugar de destaque para expor a opinião e ampará-la por meio do uso de técnicas argumentativas e argumentos. De modo a instrumentalizar a observação do gênero discursivo polêmico selecionado nesse trabalho, e tendo em vista que tomamos por embasamento teórico os conceitos da Pragmadialética, passamos a discorrer acerca dessa teoria da Argumentação no próximo capítulo. 
CAPÍTULO II -

Teorias da Argumentação diferentes perspectivas 
Este capítulo, em que se apresenta, em grande parte, a posição de van Eemeren (1983 e ss) sobre os fundamentos das Teorias da Argumentação, decorre da necessidade de se ressaltar a importância de toda e qualquer vertente teórica que, de um modo ou de outro, pode levar ao avanço da pesquisa e das discussões sobre o objeto de análise.

A Pragmadialética e as análises dela decorrentes amparam-se, principalmente, em duas orientações teóricas: nos conceitos derivados da Lógica Formal, uma proposta teórica de cunho mais normativo, que entende esse fenômeno linguístico de forma mais estruturalista e nos estudos que procuram compreender a linguagem e descrever os fenômenos intrínsecos a ela, como as correntes derivadas da Lógica Informal, da Retórica e da Pragmática. Tal aproximação tem por objetivo unificar metodológica e teoricamente tais teorias, procurando eliminar as dicotomias que podem não ser tão benéficas aos avanços científicos nos estudos da Argumentação.

Van Eemeren e Grootendorst (2004) destacam que desenvolveram sua própria variante dialética de método de pesquisa, aliando diferentes áreas da ciência e combinando uma posição filosófica crítica-racionalista com uma posição teórica "pragmadialetical", bem como apresentam uma posição analítica que se centra na resolução da diferença de opinião, uma posição empírica que se orienta em direção ao processo de convencer e uma posição prática que busca o desenvolvimento da reflexão. Ressaltam que compararam seu método à Retórica apenas para efeito de clareza, destacando que essa teoria também é um campo que possibilita inúmeras análises. Os autores chamam atenção ao fato de que, por vezes, pode ser extremamente proveitoso 
utilizar determinadas descobertas de um método na realização de uma pesquisa que se apoie em outro programa, método ou mesmo teoria.

\subsection{As teorias que tratam da Argumentação - diálogos com a Pragmadialética}

Um dos grandes representantes da Pragmadialética, o estudioso da Teoria da Argumentação, van Eemeren (2001), faz um estudo comparativo acerca de diferentes vertentes teóricas que se dedicam a observar a argumentação: a teoria derivada dos estudos de Toulmin, a Nova Retórica de Perelman e Olbrechts-Tyteca, a Lógica Informal de Walton e Johnson e Blair, a Semântica argumentativa de Ducrot, a Dialética Moderna de Barth e Krabbe, a Retórica moderna, de Reboul, e a Pragmadialética, via os estudos holandeses.

Essas teorias representam pontos fundamentais nas pesquisas atuais sobre Argumentação e influenciam, de uma maneira geral, os estudos que são realizados sobre os eventos argumentativos. De modo a permitir um breve resgate dos principais conceitos dessas teorias, apresentamos a seguir algumas considerações que possibilitam a discussão acerca das vertentes teóricas que influenciam os preceitos da Pragmadialética.

Ressaltamos que procedemos a uma breve explanação acerca das teorias citadas, tendo em vista que as inúmeras especificidades e caracterizações que se apresentam alongariam demasiadamente nossa discussão sobre pontos que não se constituirão no cerne de nossa pesquisa. Trata-se, pois, de apenas trazê-las à lembrança. 


\subsubsection{Toulmin e seu modelo de análise}

Um dos estudiosos mais profícuos da contemporaneidade, Toulmin (1958), realiza um estudo objetivando desenvolver um modelo de argumentação que consiste em um procedimento formal de argumentação ou em uma descrição das diversas etapas que podem ser caracterizadas no ato de defender uma opinião. Esse modelo é amplamente utilizado por aqueles que observam a argumentação, em especial no campo jurídico. Tal modelo configura-se da seguinte forma:

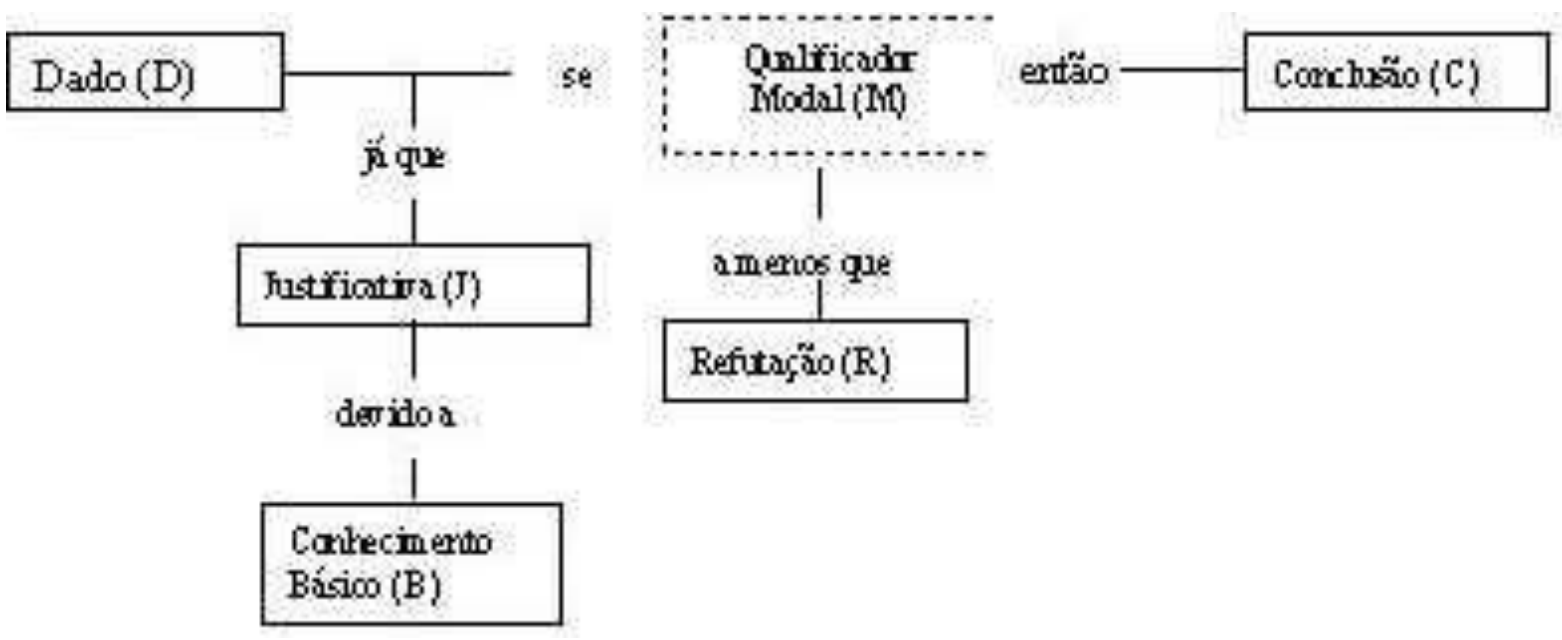

Esse modelo influenciou inúmeros estudiosos, filiados ou não à Pragmadialética, como Plantin (2008), que mais recentemente, ao retomar esse conceito de Toulmin indica seis elementos constitutivos do discurso argumentativo: dado, conclusão, lei de passagem, suporte, modalizador e restrição/refutação, que assim se correspondem: 
- uma conclusão que é afirmada com base em um dado;

- tal passo argumentativo é autorizado por uma lei de passagem que é apoiada em um suporte;

- é matizado pela introdução de um modalizador, que pode ser desenvolvido em uma restrição.

Para tornar mais clara a aplicação desse modelo em uma situação real, optamos por citar o exemplo de Plantin (op. cit., p. 27):

Dado: "Harry nasceu nas Bermudas". O termo inglês é data: "informação, algo de conhecido, do qual se pode tirar uma conclusão"

Conclusão (posição): "Harry é cidadão britânico". Claim significa "afirmação, demanda, reivindicação" de algo em um contexto de contestação. To claim é levar avante uma pretensão legítima a um direito, a uma verdade.

Lei de passagem (garantia): "dado que as pessoas nascidas na Bermudas geralmente são cidadãs britânicas." Um warrant é uma autorização, uma validação tal que so pode ser efetuada por uma lei ou um superior hierárquico; é algo apropriado. Ele significa também "justificação, boa razão para agir ou para crer", em um sentido próximo ao de "argumento".

Suporte: "Diante dos estatutos e decretos seguintes (.....)." Backing deriva de To back, que significa "reforçar, sustentar, apoiar", em um sentido que pode ser ou estritamente material, ou intelectual, "dar seu aval, encarregar-se de, assumir" (to endorse).

Modalizador: o advérbio provavelmente remete à restrição. $O$ termo inglês é qualifier; to qualify significa principalmente modificar no sentido de uma limitação, tornar menos categórico ou menos duro (to qualify a punishment: amenizar um castigo): poderíamos também utilizar "atenuador" ou "mitigador". Notemos que o modal "em geral" que afeta a lei de passagem anuncia aquele que se encontra na conclusão.

Restrição, refutação: "A menos que seus dois pais sejam estrangeiros ou que ele tenha se naturalizado como americano". O termo inglês é rebuttal; to rebut significa "contradizer, refutar, opor-se, particularmente de uma maneira explícita, ao se trazer um argumento ou uma prova".

Já o estudioso Van Eemeren (2001), ao tratar do modelo de análise do argumento proposto por Toulmin, observa que esse estudioso apresenta uma 
definição do procedimento de argumentar que independe de seu contexto ou campo; isso significa que os passos a serem dados - os quais se encontram representados no modelo - não se modificam e não apresentam relação com o objeto da argumentação em si. Entretanto, ele ressalta que o tipo de suporte, por sua vez, depende do contexto em que ocorre o evento argumentativo. Para exemplificar, pode-se dizer que uma justificação ética exige um tipo diferente de suporte que uma justificação legal. Ainda, o autor ressalta que, segundo Toulmin, o critério responsável pela avaliação da legitimidade da argumentação encontra-se em relação de dependência com o contexto. Destaca-se que esse modelo tem relação estreita com as estruturas argumentativas da Pragmadialética.

\subsubsection{A Nova Retórica de Perelman e Olbrechts-Tyteca}

De acordo com a teoria de Perelman e Olbrechts-Tyteca ${ }^{21}(1958 / 2002)$ que realiza uma espécie de renovação da Retórica Clássica, a argumentação relaciona-se à defesa de uma opinião por meio de técnicas e estratégias e apresenta, como ponto central, o auditório ao qual o evento discursivo se destina.

Na Nova Retórica, a legitimidade da argumentação é mensurada conforme seu efeito no auditório, seja ele particular ou universal, composto por aqueles que, na visão do orador, constituem um juiz. Uma das suas maiores

\footnotetext{
${ }^{21}$ Sabemos da importância desse Tratado da Argumentação. Corresponde à discussão teórica mais presente nos trabalhos de pesquisadores brasileiros. Tomaremos dessa teoria apenas dados que importem diretamente à nossa pesquisa, sem nos alongarmos, conforme já avisamos à página 60 .
} 
contribuições ao estudo da argumentação constitui-se na apresentação da listagem dos diferentes esquemas argumentativos que podem convencer ou persuadir uma audiência.

Van Eemeren (op. cit), quanto à Nova Retórica de Perelman e OlbrechtsTyteca, destaca que, com a ajuda de um esquema argumentativo do tipo quase-lógico (2002: 219), pode-se conseguir, na audiência, o efeito de considerar a opinião como defendida de maneira racional. Ainda, com a utilização de outro esquema argumentativo, como a analogia, "que estrutura a realidade" (2002:423), o auditório concluirá que a opinião defendida é aceitável de modo similar à opinião já aceita como defendida.

Para nosso trabalho, importa dessa teoria, especialmente, o conceito de auditório, que será utilizado de modo a configurar a corporeidade dos participantes do debate político eleitoral, corpus por nós selecionado.

A seguir, trataremos da Lógica Informal, linha teórica que apresenta grande relação com a Pragmadialética e promove uma aproximação em seus estudos. Ressalva-se que tal aproximação não prescinde da filiação teórica e tem por objetivo promover a discussão acerca dos principais conceitos de ambas vertentes.

\subsubsection{Lógica Informal}

O surgimento da Lógica Informal decorre da insatisfação dos pesquisadores atuais com o modo como a Lógica era tratada em seus manuais 
e livros introdutórios. Por conta disso, fundou-se, nos anos 70, no Canadá e nos Estados Unidos, o movimento que deu origem a essa teoria.

Segundo Blair e Johnson (1987), a Lógica Informal não configura um novo tipo de lógica, mas um novo processo de observar o estudo normativo da argumentação na linguagem do cotidiano, o que reflete uma maior proximidade com a prática argumentativa, se levada em conta a posição da Lógica Formal.

Essa nova concepção amparada na Lógica ocupa-se com o desenvolvimento de normas e procedimentos para interpretar, compreender e construir a argumentação de um modo que seja considerado lógico, no sentido básico do termo. Seus estudos também se dedicam a observar as relações entre as premissas e as conclusões nos argumentos, mas não se restringem à constatação, ou não, da racionalidade que objetiva viabilizar o processo de convencer, como ocorria nas práticas decorrentes do método por demonstração - que trata dos argumentos válidos cujas premissas são verdadeiras ou estão amplamente estabelecidas - amparadas pela Lógica Formal.

Segundo Blair e Johnson (1993), a busca por uma alternativa lógica, e ao mesmo tempo informal, para o critério de validade dedutiva comportaria a observância dos seguintes aspectos, o que equivale dizer que as premissas de um argumento têm de cumprir três critérios: a- relevância: se existe uma relação substancial adequada entre as premissas e a conclusão de um argumento; b- suficiência: se as premissas fornecem evidência suficiente para levar àquela conclusão e c- aceitabilidade: se as premissas são por si só verdadeiras, prováveis ou de alguma maneira confiáveis. 


\subsubsection{Semântica Argumentativa}

Ducrot e Anscombre (1983) desenvolveram uma teoria amparada na afirmação de que todas as ocorrências verbais que direcionam o interlocutor a determinada conclusão, muitas vezes implícitas, invariavelmente e sem exceção, envolvem relações argumentativas. Devido a isso, tal posição teórica foi considerada como um exemplo de Argumentatividade radical ${ }^{22}$.

Segundo van Eemeren (2001), para esses teóricos, os lexemas como "mas, apenas, ainda, porque" definem-se como operadores argumentativos e dão às ocorrências discursivas determinadas força e direção argumentativas. Ainda, destacam que o termo "mas" determina a direção da conclusão que é sugerida pela sentença e não o conteúdo dessa conclusão. Esse conteúdo é dependente tanto do contexto, quanto da situação em que a sentença é proferida. Mesmo que a conclusão possa se desenhar em um contexto específico, o termo "mas", em todos os casos, torna-a contrária e mais forte em relação à conclusão desenhada na parte anterior da sentença.

Como exemplo, temos a seguinte situação (van Eemeren, 2001, p.14):

(... ) "Paulo é rico, mas é casado" seleciona dois "princípios argumentativos" diferentes, os quais se comparam ao topoi da Retórica Clássica ((Van Eemeren et al, 1996). Nolke (1992), nesse exemplo, assume que " quanto mais alguém tem a propriedade de ser rico, mais atraente é, para uma mulher, querer conhecê-lo melhor" e "quanto mais alguém está ligado a uma mulher, menos atrativo é, para uma mulher, querer conhecê-lo melhor". Nesse caso, o último topos é um argumento mais forte do que o primeiro, o qual seria posto de lado, descartado pelo posterior. Assim, o topos posterior determina a eventual direção argumentativa da sentença, que

${ }^{22}$ De acordo com van Eemeren, 2001, p. 14. 
leva a uma conclusão implícita do tipo "É inútil tentar conhecer melhor o Paulo. ${ }^{23}$

Observa-se que, na sentença "Paulo é rico, mas é casado", a força argumentativa sugerida pelo operador "mas" transforma a conclusão delineada na segunda oração do exemplo "Paulo é casado" em muito mais forte do que a da primeira parte "Paulo é rico", conforme destacado pelos autores no exemplo traduzido em nota de rodapé.

A posição teórica de Ducrot e Ascombre influenciou estudiosos no Brasil, como Eduardo Guimarães (1987) e Ingedore Koch ${ }^{24}$ (1984), que observou a força argumentativa do termo "mas" em língua portuguesa, bem como sua orientação argumentativa.

\subsubsection{Dialética Moderna}

Outra posição, a Dialética, inspirada pela escola clássica, modernizou-se e atualmente tem como propósito definir a argumentação como parte de um procedimento para resolver uma diferença de opinião por meio de uma discussão regulada. Para os teóricos dessa teoria, a formulação de regras que

\footnotetext{
${ }^{23}$ Tradução nossa de: Paul is rich, but is married", select two different "argumentative principles" which are on a par of with the topoi of classical Rhetoric (Van Eemeren et al, 1996). Nolke (1992), in this example assumes that these are "The more someone has the property of being rich, the more attractive it is for a woman to get to know him better" and "The more someone is tied to another woman, the less attractive it is for a woman to get to know him better". In this case, the later topos is a stronger argument than the first, which is as it were put aside overruled- by the later. Thus, the last topos determines the eventual argumentative direction of the sentence, which leads to an implicit conclusion such as "It is no use trying to get to know Paul better.

${ }^{24}$ Destacam-se as obras Argumentação e linguagem. São Paulo: Cortez, 1984 e Texto e Argumentação: um estudo das conjunções do português. Campinas: Pontes, 1987.
} 
sejam instrumentais e válidas pela convenção (aceitas pelos participantes envolvidos no processo de resolver a diferença de opinião) constitui a tarefa fundamental de suas pesquisas e estudos.

As investigações iniciais da Nova Dialética constituem os trabalhos de Barth \& Krabbe (1982), que descreveram um procedimento dialético formal para determinar se uma opinião poderia ser mantida de acordo com determinados pontos de partida e concessões.

Apoiados sobre essa perspectiva, em sua primeira obra, van Eemeren e Grootendorst (1984) desenvolvem a Pragmadialética, que está de certa forma conectada à Dialética, mas apresenta diferenças importantes, principalmente no que concerne à dicotomia apresentada entre os termos "Formal" e "Pragma" (derivada de Pragmática). Os elementos pragmáticos que o termo "Pragma" pressupõe referem-se à Teoria dos Atos de Fala e à Análise do Discurso, inspiradas pelas descobertas dos filósofos que analisam a linguagem do cotidiano.

\subsubsection{Retórica Moderna}

Uma nova visão da Retórica tem sido adotada por inúmeros estudos recentes, citados a seguir, que buscam desfazer a imagem da Retórica, mantida por muito tempo, como uma teoria que se ampara em um procedimento irracional ou anti-racional. Nessa nova perspectiva, o estudo das técnicas persuasivas não seria totalmente incompatível com a manutenção de um ideal crítico de razoabilidade. 
Van Eemeren (2001) destaca que após os trabalhos pioneiros de Perelman e Olbrechts-Tyteca, inúmeras pesquisas defendem as qualidades racionais $^{25}$ da Retórica, entre eles as realizadas por Wenzel, nos EUA, Reboul, na França, Kopperschmidt, na Alemanha, e van Eemeren e Houtlousser na Holanda $^{26}$. Esses últimos têm tentado integrar os elementos da Retórica à Pragmadialética por meio do conceito de "strategic maneuvering" ${ }^{27}$ e destacam que há um objetivo retórico correspondente a cada estágio dialético do processo de resolver uma opinião. Um discurso argumentativo pode ser reconstruído, e cumprir seu objetivo com maior clareza, se forem desenvolvidos estudos e pesquisas que observem e investiguem a manobra estratégica que ocorre no estágio de seleção do potencial tópico (possíveis movimentos discursivos da discussão) disponíveis no estágio correspondente da discussão crítica, a adaptação aos desejos da audiência e o uso de recursos e técnicas de apresentação. ${ }^{28}$

As correntes teóricas citadas constituem o arcabouço teórico que embasa os trabalhos que se dedicam a observar o fenômeno argumentativo intrínseco aos eventos discursivos, sejam constituídos com maior ou menor grau de polêmica. Destaca-se que as pesquisas atuais parecem amparar-se em um ou mais conceitos de uma teoria na realização de estudos que se pautam em outra escola teórica.

\footnotetext{
${ }^{25}$ Destaca-se a aproximação com o conceito de razoabilidade da Pragmadialética, que se refere à instauração de um critério compreensível e explícito de análise, com a criação prototípica e idealizada do conceito de discussão crítica.

${ }^{26}$ In van Eemeren (2001).

${ }^{27}$ Para efeito de tradução, utilizaremos o termo "manobra estratégica".

${ }^{28}$ Os trabalhos recentes dos teóricos da Pragmadialética são dedicados a observar o conceito de manobra estratégica; entretanto nesse trabalho, faremos apenas uma breve explanação acerca dele. Reconhecemos sua importância enquanto um avanço teórico e, em decorrência disso, pesquisas futuras deverão ser a ele dedicadas.
} 


\subsection{Fundamentos da Pragmadialética enquanto teoria da argumentação}

Uma teoria da argumentação deve, de modo a estar bem fundamentada e fortemente alicerçada, combinar elementos e resultados advindos de diferentes estudos e pesquisas. De acordo com van Eemeren (2001), é tarefa dos teóricos da argumentação buscar estabelecer, de maneira clara e sólida, alguns elos entre teorias normativas, como a Lógica Formal, e outras que desenvolvem trabalhos baseados em descrições empíricas, como a Análise do Discurso. Ressalta a inter-relação que essa última estabelece entre os elementos linguísticos e sociais que permeiam um evento discursivo.

Um estudo que aborde, concomitantemente, essas duas áreas (por meio de uma idealização normativa e de descrições empíricas) pode ser possível por meio da definição da argumentação como parte, de acordo com a nomenclatura utilizada pela Pragmadialética, da "Pragmática normativa". Nessa concepção, a argumentação consistiria em um "ato de fala complexo" orientado a justificar ou refutar uma proposição e conseguir que um indivíduo, baseado em seu juízo racional, seja convencido, de modo conclusivo, sobre a aceitabilidade de uma opinião.

O aspecto descritivo dessa definição refere-se ao conceito de argumentação como um ato de fala complexo que tem propriedades pragmáticas similares aos outros tipos de ato de fala. O aspecto normativo é representado pela referência à figura de um juiz razoável, adicionando, assim, uma dimensão crítica à definição. De acordo com van Eemeren e Grootendorst 
(2004), a combinação desses dois campos da investigação científica possibilita à Pragmadialética transpor os limites de uma teoria da argumentação puramente normativa ou puramente descritiva, evitando assim, as constantes dicotomias presentes nas ciências, como aquelas observadas entre 0 empirismo e o racionalismo ou entre a realidade e o idealismo.

Uma teoria da argumentação bem estruturada integra os campos normativo e descritivo, os quais, apesar de partirem de diferentes premissas teóricas, complementam-se. Na orientação descritiva, partindo da prática argumentativa, os desafios epistemológicos e práticos encontrados no uso cotidiano da linguagem, muitas vezes, criam situações em que a teorização da argumentação não oferece soluções adequadas; já a orientação normativa contempla as considerações acerca das normas de razoabilidade presentes no ato de argumentar.

Entretanto, as regras normativas e seus procedimentos, levando-se em conta as particularidades do exercício da argumentação, podem apenas ter relevância prática se fizerem jus às características e propriedades inerentes à realidade discursiva. Isso quer dizer que as orientações teóricas da argumentação normativa e descritiva devem estar ajustadas entre si. Tal integração sistemática e metodológica exige um método de pesquisa que promova a cooperação interdisciplinar entre esses campos, de modo que seja possível ligar a orientação que parte da realidade efetiva, objetiva, material à orientação que contém os modelos ideais e abstratos.

De acordo com van Eemeren e Grootendorst (2004), de modo a constituir uma interação sistemática entre os elementos baseados na realidade 
argumentativa e aqueles baseados em um ideal de argumentação, uma teoria tem de estabelecer elos metodológicos entre os resultados das pesquisas das mais diferentes disciplinas. As descobertas baseadas na experiência, realizadas pela Linguística no estudo dos processos de interpretação, por exemplo, devem ser integradas aos conceitos da Lógica de modo a construir um sistema razoável, o qual poderia basear-se em regras que orientem a realização, de forma crítica, de um debate ou outro gênero discursivo que se paute na diferença de opinião.

Um dos propósitos da Pragmadialética refere-se ao esboço descritivo do estudo da argumentação, para o qual é possível distinguir cinco constituintes (propriedades) presentes nesse estudo: filosófica, teórica, analítica, empírica e prática. Os autores (op. cit.) destacam que cada um deles é considerado um componente necessário para que se constitua um método de pesquisa adequado, conforme a proposta apresentada por essa teoria. Passamos a discutir cada um dos cinco constituintes, de modo a explicitar sua relevância nos estudos que se baseiam na descrição do processo de argumentar.

\subsubsection{A propriedade filosófica}

Para van Eemeren e Grootendorst (2004), teóricos da argumentação, que por muito tempo vêm dedicando seus estudos a verificar os conceitos de certo ou errado e/ou de verdade ou falsidade, têm por tarefa a investigação do modo como se conquista a aceitabilidade de uma opinião, além de observar como ocorre a alegação, por parte dos interlocutores, da verdade ou falsidade 
de uma opinião e a maneira como é (ou deveria ser) atacada ou amparada. Quer dizer, o processo de argumentar teria, na opinião desses teóricos, mais importância do que o produto em si.

A definição de argumentação, proposta pela Pragmadialética, pressupõe que argumentar é produzir efeitos: a performação de um ato de fala complexo tem por objetivo convencer um indivíduo, que se constitui em um juiz baseado na razoabilidade, sobre determinado ponto de vista. Assim, investigar a força de convencimento da argumentação utilizada em uma interação verbal seria tarefa daqueles que estudam os discursos argumentativos.

Para que se compreenda tal processo de convencimento dos indivíduos, faz-se necessário destacar o conceito de razoabilidade, responsável pelo juízo que rege a aceitabilidade de determinado ponto de vista. Para a Pragmadialética, esse conceito não é de fácil definição por encontrar-se fortemente imbricado em premissas de várias naturezas, conforme van Eemeren e Grootendorst (2004, p. 13):

(...) a escolha de uma perspectiva particular sobre a razoabilidade é frequentemente acompanhada por uma seleção de uma série de premissas de natureza epistemológica, ideológica, didática e por vezes puramente prática.

Para maior clareza acerca da razoabilidade, podemos citar Toulmin (1976), quem destaca ser possível observar três perspectivas desse conceito: a geométrica, a antropológica e a crítica. Os filósofos que adotam a perspectiva geométrica buscam demonstrar "como algo é" e provar suas afirmações por meio da demonstração detalhada de como essas afirmações derivam de algo 
incontestável e absoluto. Aqueles que optam pela perspectiva antropológica e crítica preferem discutir problemas e convencer os outros por meio da argumentação, levando em conta que é necessário distinguir entre duas posições relacionadas ao ponto de vista defendido argumentativamente: a posição da pessoa que quer convencer e a daquela que será convencida. A visão geométrica da razoabilidade é parte integrante da tradição demonstrativa, a qual seria, de fato, antiargumentativa.

O princípio da perspectiva antropológica refere-se ao fato de a cultura limitar ou nortear o conceito do que é racional ou razoável. Tal influência acaba por atribuir a essas noções determinada relatividade e, assim, esses conceitos não seriam universais e objetivos, mas sim permeados e limitados pela cultura e intersubjetivos. Além disso, eles não seriam estáticos, mas dinâmicos, o que significa dizer que estão sujeitos a mudanças. Portanto, o que é considerado razoável é concernente a sujeitos e determinado por eles e pelo tempo, ou seja, é específico a sujeitos particulares em um determinado contexto histórico. Por conta disso, a Pragmadialética nomeia essa visão de razoabilidade como uma perspectiva antropológica e relativista ${ }^{29}$.

O ponto de partida da perspectiva crítica da razoabilidade centra-se na afirmação da inexistência da certeza, acarretando no ceticismo sobre determinado ponto de vista, independente de quem o fizer e do conteúdo a que se refere.

\footnotetext{
${ }^{29}$ Esse relativismo pode ser observado por meio do conceito de Wittgenstein (1979) de jogos de linguagem, os quais constituiriam uma maneira específica de diferenças de opinião e poderiam apresentar variações no modo de discutir, típicas de determinados jogos de linguagem.
} 
Essa perspectiva baseia-se na discussão, de modo a encorajar uma apresentação sistemática da opinião de uma parte às dúvidas críticas da outra parte até que a diferença de opinião seja resolvida de maneira aceitável para os participantes. Nesse processo, toda argumentação é considerada parte da discussão crítica entre participantes que estejam preparados para ampará-la por meio de um procedimento acordado entre si.

A visão crítica da razoabilidade proposta pela Pragmadialética combina elementos das perspectivas geométrica e antropológica. Através da proposta de um procedimento de discussão na forma de uma série de regras independentes para debatedores que queiram agir razoavelmente, o campo da normatização é decorrente da perspectiva geométrica. Entretanto, ocorre de maneira crítica, pois esse procedimento formalista é criado para facilitar a discussão que irá resolver uma diferença de opinião. A instauração de regras é válida desde que elas realmente facilitem aos participantes a resolução da diferença de opinião.

Na Pragmadialética, não se assume, de modo algum, a existência de uma forma absoluta e definitiva da razoabilidade. Na perspectiva crítica, considera-se a razoabilidade um conceito gradual, pois o grau em que ela aparece em determinada regra depende de sua adequação como parte de um procedimento para a condução de uma discussão crítica para, assim, resolver o problema.

De acordo com van Eemeren e Grootendorst (2004), outro conceito que tem relação com a razoabilidade conforme caracterizada pela perspectiva crítica é o critério de "validade intersubjetiva". A adição desse critério ao 
problema da validade de determinada proposição, no que concerne ao conceito aplicado pela Lógica, refere-se ao fato de a aceitabilidade da audiência conectar-se ao pensamento comum e natural. Existe uma série de proposições aceitas de modo geral e por vezes universal; entretanto, para os outros casos é necessário construir propostas que possibilitem, aos usuários da língua, diversas maneiras de resolver suas diferenças de opinião por meio da argumentação. De modo a apresentar uma alternativa ou, no mínimo, um "frame ${ }^{30}$ de referência" como modelo idealizado, que coloque em evidência a qualidade da argumentação, a Pragmadialética adota a perspectiva críticaracionalista de razoabilidade.

\subsubsection{A propriedade teórica}

Neste item, aborda-se um modelo do que significa para um indivíduo, baseado em seu juízo racional, o julgamento da razoabilidade. Na idealização teórica referente aos conceitos propostos pela Pragmadialética, fornecem-se um panorama dos "moves" 31 relevantes e uma definição dos fatores que ocupam papéis importantes nessa teoria da argumentação.

Para tanto, desenvolvem-se determinados modelos teóricos, alguns com propósitos descritivos, como é o caso do modelo idealizado de discussão crítica. Certo grau de idealização é sempre inerente à configuração de um

\footnotetext{
${ }^{30}$ Conforme Fávero (2001, p.64): "Os frames estabelecem que elementos em princípio, fazem parte de um todo, mas não estabelecem entre eles uma ordem ou sequência (lógica ou temporal)", ou seja, ao pensarmos em um conceito como "Festa de aniversário", ativamos elementos como: doces, música, decorações, bolo, velas, etc., que, relacionados, constituem um frame de festa de aniversário.

${ }^{31}$ Conforme o conceito de ato de fala proposto pela Pragmática.
} 
modelo, e tal abstração adotada é uma extensão do ponto de vista do pesquisador sobre o que significa para um indivíduo, baseado em seu juízo racional, julgar razoavelmente. Os teóricos da argumentação necessitam de um modelo idealizado para conseguirem observar as dificuldades da realidade argumentativa e para solucioná-las de um modo sistemático. O modelo idealizado cumpre um papel instrumental na ligação do abstrato filosófico com a realidade de fato.

Em relação a esse tópico, van Eemeren e Grootendorst (2004) dissertam sobre a corrente epistemológica e retórica da argumentação, para a qual apresentam a perspectiva antropológica e relativista da razoabilidade. Estudos baseados nessa concepção buscam saber se a argumentação teve sucesso em persuadir a audiência e observam esse processo por meio da análise das reações do público-alvo às opiniões em debate. Salientam que a Nova Retórica de Perelman e Olbrechts-Tyteca fornece um catálogo de pontos de partida de esquemas argumentativos que podem desempenhar um papel efetivo nas técnicas argumentativas de persuasão; entretanto, faz-se necessário pesquisar se o uso desses esquemas de argumentos e técnicas é realmente persuasivo e qual a combinação exata e sob quais circunstâncias eles são mais efetivos.

De acordo com van Eemeren e Grootendorst (2004), para realizar esse tipo de pesquisa, é importante levar em conta os estudos que comparam o conceito de razoabilidade às regras argumentativas inerentes aos eventos discursivos correspondentes das mais diferentes culturas. Uma vez que a observação dos fatos empíricos, supostamente, depende de uma grande gama de paradigmas teóricos, os quais, por sua vez, dependem das visões de mundo 
e premissas culturais nas quais se baseiam, torna-se fundamental ter um conhecimento confiável sobre esses dados.

A Pragmadialética opta por investigar os dispositivos argumentativos utilizados em uma discussão sob a ótica do problema da validade e da validade intersubjetiva das regras para a discussão crítica. Como os estudos derivados dessa teoria têm raiz na Dialética, van Eemeren e Grootendorst (op. cit.) ressaltam que se deve observar o papel da argumentação no procedimento para resolver essa discussão. Ainda, é necessário analisar quais questões correspondem aos esquemas argumentativos utilizados na argumentação e como essas questões devem ser respondidas, em cada caso particular. Por meio dessa pesquisa, possibilitam-se resultados proveitosos que derivem dos elementos teóricos desenvolvidos na Pragmadialética.

Essa teoria considera a argumentação como parte de uma discussão explícita ou não entre participantes que tentam resolver a diferença de opinião (que poderá ser implícita) por meio do teste da aceitabilidade dos pontos de vista concernentes. Para que se dê esse processo, o participante tem de cumprir determinados estágios, analisados teoricamente no modelo idealizado de discussão crítica, conforme proposto pela Pragmadialética. Esse modelo teórico pode ser considerado dialético, porque ocorre entre duas partes que tentam resolver uma diferença de opinião através de uma troca metodológica de "moves" da discussão; e pragmático, porque esses "moves" são descritos como atos de fala performativos realizados em situações e contexto específicos. 
O modelo idealizado também indica quais regras aplicam-se aos diferentes atos de fala em cada um dos estágios da discussão crítica; cada uma delas constitui-se como necessária, e cada violação a ela é um risco potencial à resolução dessa diferença de opinião. As violações correspondem "grosseiramente" aos movimentos argumentativos tradicionalmente conhecidos como falácias. O código de conduta para uma discussão crítica baseado nessas regras deriva seu problema de validade precisamente do fato de não permitir falácias.

Seja um modelo teórico que se foca na vitória de um participante de um debate ou disputa ou uma metodologia que procura ser auxiliar à resolução de diferenças de opinião, torna-se imprescindível interpretar e compreender a realidade argumentativa, ligada ao contexto situacional, antes de se especificar de que modo os elementos produzidos pelo uso do modelo podem ser, na prática argumentativa, úteis ao processo de resolver um evento discursivo de grande polêmica.

\subsubsection{A propriedade analítica}

A Pragmadialética possibilita reconstruir a argumentação utilizada em uma diferença de opinião por meio do conceito de modelo idealizado de discussão crítica; o que consiste em dizer que o modelo não é submetido a um teste empírico, mas utilizado de maneira a reconstruir a realidade argumentativa (um discurso ou texto) para revelar a extensão em que essa realidade, realmente, corresponde à idealização do modelo. 
De acordo com van Eemeren e Grootendorst (2004), haverá riscos em uma análise, se a teoria da argumentação utilizada busca ser, essencialmente, prática. Uma teoria deve incorporar tanto 0 aspecto normativo quanto 0 descritivo, razão pela qual a reconstrução que possibilite a análise da argumentação utilizada no discurso oral e/ou escrito deve combinar essas duas orientações.

A reconstrução deve refletir as características e propriedades da realidade argumentativa, bem como aquelas do modelo idealizado que constitui o "frame" da análise. Afinal, a importância de tal reconstrução analítica é de que tanto o ideal filosófico, que se refere aos elementos derivados da metodologia analítica dos argumentos, quanto o real prático sejam unificados de modo significativo. Essa confluência pode ocorrer por meio da integração sistemática da norma e da descrição, de modo a produzir uma teoria que as una para possibilitar um novo olhar teórico no desenvolvimento de pesquisas e análises. Destaca-se que os autores (op. cit.) ressaltam a importância determinante da propriedade analítica de seu método para o estudo da argumentação.

Ao participarmos de um evento discursivo, qualquer que seja o gênero, para que estejamos aptos a expressar opiniões adequadas ao contexto do evento e que sejam bem embasadas, torna-se necessário saber em que medida determinadas expressões estão em conformidade com o propósito a que, supostamente, destinam-se. É relevante observar a carga argumentativa que aquele discurso apresenta, ou seja, por se tratar de um evento único e ligado aos dados do contexto, a reconstrução analítica é sempre de caráter 
provisório. Ainda, ela somente é importante e tem relevância se parte do discurso pode ser, genuinamente, caracterizada como argumentativa.

Ressalta-se que tal afirmação relaciona-se à definição da argumentação enquanto parte de uma discussão crítica, ou seja, ela é compreendida como um estágio observável na análise de um evento discursivo.

A Pragmadialética defende que a reconstrução pode fornecer um perfil claro da argumentação, especialmente no caso de textos mais complexos, trazendo, por meio do modelo idealizado, maior clareza no uso de argumentos. Essa reconstrução consiste de vários tipos de operações de transformação: seleção, adição e reajuste para reformular os elementos relevantes do discurso. Para que a reconstrução seja adequada, as transformações devem ser totalmente justificáveis, podendo ser explicadas devido à necessidade de sua realização (referindo-se, invariavelmente, ao modelo de discussão crítica e ao texto) e destacando-se as possíveis implicações que decorrem dessas transformações.

Destacamos que em nosso trabalho, a reconstrução se dá de modo a explicitar as possíveis ocorrências de atos de fala que são relevantes no sentido de se constituírem em violações às regras que orientam o andamento de uma discussão crítica.

A importância de realizarem-se estudos que aliem diferentes concepções teóricas pode decorrer da afirmação de que, em uma análise filiada à perspectiva Epistemológica e Retórica, a reconstrução seria orientada para a audiência, de modo a esclarecer os elementos mais persuasivos do 
discurso, tornando-a, essencialmente, retórica. Esse tipo de análise se dá por meio dos trabalhos derivados da teoria da Nova Retórica de Perelman e Olbrechts-Tyteca. Entretanto, de acordo com van Eemeren e Grootendorst (2004, p. 25):

(...) essas análises deixam a impressão de serem, primordialmente, ad hoc porque elas parecem inclinar-se fortemente na intuição particular e individual. Apesar da longa tradição dessa forma de análise, não há ainda um método consistente para a condução da análise retórica que forneça as instruções necessárias para a implementação das transformações que se façam necessárias e nem mesmo o reconhecimento da necessidade de tal método. Mais do que isso, a importância de se apresentar uma dimensão normativa para a análise é frequentemente ignorada.

Ainda, os autores ressaltam que esse tipo de análise, em que não há a comparação com um modelo idealizado, compreende a argumentação, exclusivamente, por meio do ponto de vista dos participantes da discussão e deixa que os dados coletados "falem por si mesmos". Para a Pragmadialética, sem a existência de um determinado "frame" teórico de referência, mesmo que implícito, os elementos não poderiam ser classificados como dados de análise. Tal declaração decorre do fato de faltar um ponto de partida teórico, como um conjunto de diretrizes, claramente apresentado, o que causaria a tal tipo de teoria da argumentação, vinculado à interpretação ad hoc e individual, uma espécie de vulnerabilidade teórica na explicação de suas análises.

Em vista dessa afirmação, observa-se a contribuição teórica da Pragmadialética, em que se realiza a reconstrução orientada à resolução, na qual se procura descobrir como é possível determinar quais os atos de fala presentes no discurso que desempenham um papel para resolver a diferença 
de opinião, ou seja, devem-se efetuar as análises por meio de transformações que reconstruam o texto como uma tentativa de resolver essa diferença. Isso se torna factível por meio da exposição dos estágios relevantes da discussão crítica e da reconstrução de seu conteúdo.

Acreditamos ser esse o cerne de uma proposta teórica que apresente um método de análise que busque ser completo, se constitua como adequado, e se dedique a observar os eventos discursivos. Nossa seleção teórica constitui, assim, uma ferramenta de pesquisa que possibilita uma metodologia de análise baseada em conceitos idealizados que tentam garantir um exame específico e detalhado da argumentação.

A seguir, passamos à discussão proposta por van Eemeren e Grootendorst (2004) a respeito da propriedade empírica relacionada à constituição de uma teoria que oferece um método para a análise da argumentação.

\subsubsection{A propriedade empírica}

Nesta propriedade, os autores (2004) dissertam acerca da diferença nos objetos de análise de duas vertentes teóricas: a Retórica, que se preocupa com a análise de como a persuasão funciona na ocorrência de um evento discursivo, e a Pragmadialética, a qual opta por observar as descrições empíricas do processo de convencimento envolvido em uma diferença de opinião, ou seja, como os debatedores ou participantes desse evento discursivo conseguem resolvê-lo esclarecendo todas as dúvidas sobre a 
opinião em pauta. Parece possível dizer que a Pragmadialética busca responder à seguinte pergunta: "Como descobrir quais fatores e processos são importantes para a força de convencimento do discurso argumentativo que busca resolver uma diferença de opinião?".

Para a Pragmadialética, as atividades cognitivas realizadas para convencer $^{32}$ uma audiência são mais complexas do que aquelas envolvidas em persuadi-la. Enquanto a persuasão implica no efeito imediato apresentado pela audiência em reação aos argumentos e estratégias, o convencimento só pode ocorrer após determinada reflexão posterior da pessoa que deveria ser convencida. Antes de considerar o quanto a argumentação foi convincente, o indivíduo precisa compreendê-la bem e entender exatamente o que ela envolve. Ainda, para van Eemeren e Grootendorst (2004), as técnicas retóricas, frequentemente, devem seu sucesso justamente ao fato de não serem reconhecidas como estratégias ou técnicas, passando despercebidas pelos participantes envolvidos no evento discursivo.

Para os autores (op. cit.), uma descrição adequada do processo do convencimento exigiria uma série de pesquisas que dialogassem entre si, bem como um processo sistemático, por exemplo, que investigasse os possíveis problemas envolvidos nesse procedimento. A pesquisa que busca identificar os problemas pode variar quanto à descrição dos fatores que interferem na argumentação, seja ela simples, indireta ou complexa, de modo a descrever os processos em conexão com essa identificação.

\footnotetext{
32 Há diferentes posições quanto a esses conceitos. Assumimos, nesse trabalho, a indicada pelos autores por entendermos que o processo de reflexão sobre uma opinião ou ponto de vista pode ser fundamental na resolução de uma discordância.
} 
Uma pesquisa empírica significativa para os teóricos da Pragmadialética pode relacionar-se, por exemplo, a questionar em que extensão os usuários da linguagem cotidiana nos contextos diários realmente tendem a resolver suas diferenças de opinião, utilizando o tipo de discussão por ela propagado, além de procurar saber quais pistas são fornecidas pela realidade argumentativa para determinar se uma confrontação (estágio inicial da discussão crítica ${ }^{33}$ ) acontecerá, ou qualquer outra interação que possa ser considerada como um estágio específico da discussão crítica. Assim, questionam: será que os esquemas argumentativos e as estruturas de argumentação definidas pela Pragmadialética realmente desempenham papéis que direcionam a prática argumentativa diária? Será que há indicações de que os debatedores comuns, ao interpretarem a argumentação um do outro, estão realmente efetuando transformações que são similares àquelas utilizadas pelos teóricos da Dialética? Esse tipo de questionamento pode constituir um campo de estudos adequado às pesquisas empíricas que se dedicam a descrever o discurso argumentativo centrado no processo de convencer.

De modo a possibilitar a realização de tais pesquisas empíricas, faz-se necessária a explanação acerca da propriedade prática referente ao método proposto pela Pragmadialética, conforme o item a seguir.

\subsubsection{A propriedade prática}

Para a Pragmadialética, o campo de estudos da argumentação constitui todos os eventos institucionalizados, ou não, em que os indivíduos utilizam-se

${ }^{33}$ Os estágios da discussão crítica serão abordados no item 2.4, localizado à página 104 de nosso trabalho. 
do discurso: desde as deliberações formais nos tribunais de justiça, os debates políticos e os encontros informais. Por conta dessa amplitude de eventos, a produção de um discurso argumentativo, seja oral e/ou escrito, requer inúmeros tipos de competência argumentativa, a qual tem relação com a capacidade de agir de acordo com as condições situacionais, de modo a utilizar diferentes habilidades, característica individual e que se encontra relacionada a aspectos culturais, pessoais e sociais.

De acordo com van Eemeren e Grootendorst (2004), a competência argumentativa é tão complexa que sua composição inclui vários tipos, diferentes competências. Por exemplo, um indivíduo pode ser muito competente ao participar de um evento em que se utilize da argumentação, mas pode não demonstrar a mesma eficiência em analisá-la ou em avaliá-la.

De modo geral, o termo "competência argumentativa" (mesmo que, teoricamente, não apresente uma definição clara) refere-se a todos os componentes que se apresentam à disposição dos indivíduos e que estão relacionados aos contextos de cada situação discursiva e a cada participante de tal evento.

Essa espécie de relatividade da competência argumentativa implica na medição da competência individual, inicialmente, em termos do padrão pertinente a tipos específicos de contexto em que ela deve ser aplicada. Para melhorar a prática argumentativa, de modo intencional e planejado, a argumentação deve ser estudada e pesquisada nos mais variados contextos, em maior ou menor grau de definição do procedimento argumentativo. Há ocasiões em que, determinadas, as regras da discussão costumam ser mais 
claras, como nos contextos institucionalizados, nos quais há consequências para o não-cumprimento das exigências que são feitas à competência argumentativa do indivíduo.

A prática argumentativa, e consequentemente a competência, podem ser desenvolvidas por meio da proposta de novos procedimentos argumentativos, os quais devem levar em conta os objetivos institucionais determinados por uma prática específica. Em qualquer caso, ao criarem-se métodos ou propostas para melhorar a prática argumentativa ${ }^{34}$, tem-se a necessidade de destacar a observação dos elementos de produção, análise e avaliação do discurso argumentativo que foram resultado das recentes pesquisas derivadas das propriedades filosófica, teórica, analítica e empírica. Essas descobertas deveriam ser cuidadosamente transformadas em resultados que satisfaçam os critérios divergentes que se aplicam ao discurso argumentativo nos mais variados campos de ocorrência.

De acordo com van Eemeren e Grootendorst (2004), o conhecimento derivado dessas descobertas - seja ele relativo à visão antropológica e relativista, encontrando-se focado na aprovação pela vitória, ou concernente à visão crítica-racionalista, centrando-se em resolver as diferenças de opinião deve ser aplicado à criação de novas propostas para o desenvolvimento da argumentação, as quais devem estar amparadas por um método que tenha por objetivo levar aos resultados desejados ou acelerar o alcance do propósito que um determinado discurso oral ou escrito pretende cumprir.

\footnotetext{
${ }^{34}$ Ressaltamos que o refinamento ou a melhora da prática argumentativa não se constitui em um objetivo de nosso trabalho.
} 
Em suma, de modo a reafirmar as propriedades de uma teoria que se dedica a estudar a Argumentação, da maneira que elas encontram-se conceituadas pela Pragmadialética e com o propósito de defini-las, podemos retomá-las do seguinte modo:

\begin{tabular}{|c|c|}
\hline PROPRIEDADE & MÉTODO PROPOSTO PELA PRAGMADIALÉTICA \\
\hline Filosófica & $\begin{array}{l}\text { - Perspectiva crítica da razoabilidade: a inexistência da } \\
\text { certeza. } \\
\text { - É focada na discussão: uma apresentação sistemática } \\
\text { da opinião de uma parte às dúvidas críticas da outra parte } \\
\text { até que a diferença de opinião seja resolvida de maneira } \\
\text { aceitável para os participantes. }\end{array}$ \\
\hline Teórica & $\begin{array}{l}\text { - A argumentação é parte uma discussão explícita ou não; } \\
\text { - O participante tem de cumprir determinados estágios, } \\
\text { analisados no modelo idealizado de discussão crítica. } \\
\text { - Modelo dialético porque ocorre entre duas partes que } \\
\text { tentam resolver uma diferença de opinião através de uma } \\
\text { troca metodológica de "moves" da discussão; e } \\
\text { pragmático porque esses "moves" são descritos como } \\
\text { atos de fala performados em situações e contexto } \\
\text { específicos. } \\
\text { - Indica quais regras aplicam-se à performação de } \\
\text { diferentes atos de fala, em cada um dos estágios da } \\
\text { discussão crítica; cada violação a ela corresponde aos } \\
\text { argumentos tradicionalmente conhecidos como falácias. }\end{array}$ \\
\hline Anal & $\begin{array}{l}\text { - O modelo idealizado de discussão crítica é utilizado de } \\
\text { maneira a reconstruir a realidade argumentativa (um } \\
\text { discurso ou texto) para revelar a extensão em que essa } \\
\text { realidade corresponde à idealização do modelo. }\end{array}$ \\
\hline Empírica & $\begin{array}{l}\text { - Questiona em que extensão os usuários da linguagem } \\
\text { cotidiana nos contextos diários realmente tendem a } \\
\text { resolver suas diferenças de opinião utilizando o tipo de } \\
\text { discussão por ela propagado. } \\
\text { - Estudos que se dediquem à produção de descrições do } \\
\text { discurso argumentativo centrado no processo de } \\
\text { convencer. }\end{array}$ \\
\hline Prática & $\begin{array}{l}\text { - O campo de estudos da argumentação inclui todos os } \\
\text { eventos institucionalizados, ou não, em que os indivíduos } \\
\text { utilizam-se do discurso. Desde as deliberações formais nos } \\
\text { tribunais de justiça, os debates políticos e os encontros } \\
\text { informais. }\end{array}$ \\
\hline
\end{tabular}

Quadro 2- O método para pesquisa da argumentação proposto pela Pragmadialética. 
A Pragmadialética leva, em princípio, a uma diretriz no sentido de se aplicar, na prática, os conhecimentos derivados da teoria, o que caracteriza o ato de refletir acerca da argumentação. A ênfase é dada à possibilidade de usá-la para resolver diferenças de opinião e configura-se em uma maneira de estimular os indivíduos a participar de um diálogo crítico, caso pretendam convencer outras pessoas, por meio do fornecimento de um método que os capacite a agir adequadamente na ocorrência do discurso argumentativo, nas mais variadas situações.

A criação do método proposto por essa teoria originou-se da necessidade que viram seus pesquisadores de concentrar ou estimular uma reflexão sistemática sobre a argumentação produzida por um indivíduo ou por meio da qual ele é confrontado (protagonista e antagonista de uma discussão crítica). As regras da discussão crítica criadas pela Pragmadialética procuram demonstrar a reflexão sistemática sobre o que significa a razoabilidade na teoria da argumentação.

Entretanto, ressalta-se que o uso adequado desse instrumento não pretende significar unicamente a memorização de tais regras, para que, dessa forma, esteja-se apto a aplicá-las com sucesso na prática. Esse conceito não se configura em um processo normativo, válido para ser seguido sem qualquer observação do contexto e da prática discursiva.

De acordo com van Eemeren e Grootendorst (2004, p. 38), "Essas regras não são algoritmos, mas heurísticas, elas não levam automaticamente a uma série específica de instruções que sempre garantem o resultado 
desejado"35. A argumentação, na Pragmadialética, não se configura em um processo mecânico, mas em uma atividade social que objetiva convencer os outros acerca da aceitabilidade de uma opinião através do esclarecimento da dúvida dos interlocutores. De acordo com essa teoria, a qualidade da produção, análise e avaliação do discurso argumentativo pode ser refinada, exclusivamente, pela evolução no processo de comunicação e interação entre os interlocutores.

Esse refinamento pode dar-se por meio de procedimentos argumentativos como inserções diretas que explicitem proposições, ou etapas, que tenham ficado implícitas ou ambíguas. Ainda, ele pode ocorrer através da compreensão dos indivíduos sobre as aplicações práticas do conhecimento derivado da teorização da argumentação, pois os interlocutores devem estar familiarizados com certas práticas discursivas e possuir certas habilidades consideráveis, para que a discussão se torne profícua.

A Pragmadialética explicita que 0 processo de argumentar exige determinadas condições que são nomeadas de regras de primeira, segunda e terceira-ordem. Em relação às de primeira-ordem, destaca-se que elas podem sobrepor-se às normas que os debatedores de eventos do cotidiano já tenham na prática, sejam elas naturais ou internalizadas por meio do conhecimento dos processos que as desenvolveram. Às vezes, existem fatores além do controle dos debatedores que podem retardar a adoção da postura razoável propagada pelo código de conduta. Os estados mentais que são considerados uma condição prévia para uma postura razoável (concernente aos indivíduos que

\footnotetext{
${ }^{35}$ Grifos nossos.
} 
tenham por objetivo resolver uma diferença de opinião por meio da exposição de opiniões e do uso da argumentação) durante a discussão podem ser entendidos como as condições de segunda-ordem para uma discussão crítica, enquanto as condições externas nas quais a argumentação ocorre são classificadas como condições de terceira-ordem. ${ }^{36}$

As condições de primeira-ordem determinam que as partes não podem impedir-se mutuamente de apresentar opiniões ou expressar quaisquer dúvidas em relação a elas. As de segunda-ordem ressaltam que as partes devem estar preparadas para expressar suas opiniões e para ouvir a dos seus interlocutores, o que pode ser promovido por meio da reflexão sobre os objetivos e méritos da argumentação. Já as condições de terceira-ordem têm relação com certos requisitos políticos: para a condução de uma discussão crítica, as circunstâncias devem garantir a liberdade individual, o direito a expressar livremente a informação e a crítica, a não-violência e o pluralismo intelectual. Se essas condições forem preenchidas, a noção de razoabilidade adquire, além de seu significado intelectual, um significado social.

\subsubsection{Um programa para o estudo da argumentação}

De modo a possibilitar métodos para o estudo e a pesquisa da argumentação, van Eemeren e Grootendorst (2004) oferecem um programa

\footnotetext{
${ }^{36}$ De acordo com van Eemeren( 1987), essas condições derivam dos estudos de Lógica e
} Argumentação realizados por Barth e Krabbe (1982). 
que contempla as cinco propriedades que constituem o escopo dos estudos argumentativos. Por meio de exemplos em forma de perguntas (que configuram a personificação de um juiz razoável) e respostas, os autores fornecem duas versões alternativas de um programa de pesquisas: a versão da Dialética (origem da Pragmadialética) contrastando com a versão da Retórica ${ }^{37}$; entretanto, ressaltam que, por vezes, na prática, certos elementos das duas visões podem ser combinados.

Passamos à exposição dos itens apresentados pelos autores (2004, p. 38-39) ${ }^{38}$, conforme quadro a seguir:

\begin{tabular}{|c|c|}
\hline \multicolumn{2}{|c|}{ I - A propriedade filosófica } \\
\hline Juiz razoável: & $\begin{array}{l}\text { Quando eu devo, como crítico racional que julga } \\
\text { razoavelmente, considerar a argumentação } \\
\text { aceitável? }\end{array}$ \\
\hline$R^{39}-I$ & $\begin{array}{l}\text { Quando a argumentação corresponder aos } \\
\text { padrões em uso no contexto cultural em que ela } \\
\text { ocorre. }\end{array}$ \\
\hline$D^{40}-1$ & $\begin{array}{l}\text { Quando a argumentação resolver uma diferença } \\
\text { de opinião de acordo com as regras da discussão } \\
\text { (problema da validade) que são aceitáveis às } \\
\text { partes. }\end{array}$ \\
\hline \multicolumn{2}{|c|}{ II - A propriedade teórica } \\
\hline Juiz razoável: & $\begin{array}{l}\text { Quais instrumentos estão disponíveis para que eu } \\
\text { trate, sistematicamente, dos problemas } \\
\text { concernentes à aceitabilidade da argumentação? }\end{array}$ \\
\hline$R-I I$ & $\begin{array}{l}\text { Eu posso utilizar certa quantidade de informação } \\
\text { sobre as visões dos diferentes auditórios e sobre } \\
\text { as maneiras pelas quais essa informação pode ser } \\
\text { aplicada na argumentação. }\end{array}$ \\
\hline$D-I I$ & $\begin{array}{l}\text { Eu posso utilizar um modelo idealizado de } \\
\text { discussão crítica que objetiva resolver uma } \\
\text { diferença de opinião e uma série de regras para a } \\
\text { performação de atos de fala relevantes à } \\
\text { discussão. }\end{array}$ \\
\hline III & lalítica \\
\hline
\end{tabular}

\footnotetext{
${ }^{37}$ Os autores destacam que a comparação tem, exclusivamente, fins ilustrativos.

38 Tradução nossa.

${ }^{39}$ Retórica; refere-se às respostas dessa escola teórica às perguntas do juiz razoável.

${ }^{40}$ Dialética; refere-se às respostas dessa escola teórica às perguntas do juiz razoável.
} 


\begin{tabular}{|c|l|}
\hline Juiz razoável: & $\begin{array}{l}\text { Como eu posso obter uma imagem clara do todo } \\
\text { que é relevante para minha avaliação de um } \\
\text { discurso ou texto argumentativo? }\end{array}$ \\
\hline R - III & $\begin{array}{l}\text { Reconstruindo o discurso ou texto como uma } \\
\text { tentativa de persuadir o auditório e expondo os } \\
\text { padrões retóricos que são utilizados. }\end{array}$ \\
\hline D - III & $\begin{array}{l}\text { Reconstruindo o discurso ou texto como uma } \\
\text { tentativa de resolver a diferença de opinião, por } \\
\text { meio da utilização das transformações dialéticas } \\
\text { requeridas. }\end{array}$ \\
\hline IV - A propriedade empírica \\
\hline Juiz razoável: & $\begin{array}{l}\text { Eu posso adquirir qual conhecimento sobre a } \\
\text { realidade argumentativa que poderá ser utilizado? }\end{array}$ \\
\hline R - IV & $\begin{array}{l}\text { Posso investigar quais os tipos de auditório e } \\
\text { quais estratégias retóricas que, possivelmente, } \\
\text { serão mais persuasivas aos diferentes auditórios. }\end{array}$ \\
\hline D - IV & $\begin{array}{l}\text { Posso investigar quais fatores e processos são } \\
\text { importantes no discurso argumentativo para } \\
\text { convencer alguém que esteja em dúvida sobre a } \\
\text { aceitabilidade de uma opinião. }\end{array}$ \\
\hline V- A propriedade prática \\
\hline Juiz razoável: & $\begin{array}{l}\text { Como posso contribuir para o aprimoramento da } \\
\text { prática argumentativa? }\end{array}$ \\
\hline R - V & $\begin{array}{l}\text { Posso ensinar às pessoas a se aproximarem de } \\
\text { seus auditórios de tal maneira que estejam (nas } \\
\text { mais diferentes circunstâncias) aptas a vencer um } \\
\text { confronto argumentativo; ainda, posso ensiná-las a } \\
\text { perceber as maneiras mais fáceis de dispersar a } \\
\text { argumentação do outro. }\end{array}$ \\
\hline & $\begin{array}{l}\text { Posso promover a reflexão acerca dos processos } \\
\text { usados nas diferentes práticas argumentativas e } \\
\text { as habilidades necessárias à produção, análise e } \\
\text { avaliação adequadas do discurso argumentativo. }\end{array}$ \\
\hline
\end{tabular}

Quadro 3 - Comparação entre os métodos de pesquisa da Retórica e da Dialética.

Em relação ao programa proposto pela Pragmadialética, deve-se destacar que cada uma das cinco propriedades abordadas refere-se a um domínio específico que tem de ser abordado através de um método de pesquisa que leve a uma teoria totalmente alicerçada. Há uma dependência mútua entre os cinco componentes do programa de pesquisa, e um estudo abrangente que deveria cobrir os cinco domínios. Ainda, a realização de uma 
análise comparativa dos elementos constituintes de uma determinada propriedade poderá esclarecer inúmeros problemas, como veremos a seguir.

Van Eemeren e Grootendorst (2004) apresentam a metáfora do Estado para explicar a necessidade das cinco propriedades no estudo da argumentação: para que funcione adequadamente, um Estado deve possuir uma constituição, seja escrita ou não (propriedade filosófica); ele precisa de regras e leis específicas para saber como as complexidades da vida cotidiana devem ser administradas adequadamente (a propriedade teórica). O Estado também necessita de alguma forma de administração para a implementação correta das leis, regras e regulamentos (a propriedade analítica); essa administração deve assegurar que a justiça seja aplicada conforme a possibilidade e a exigência da realidade social (a propriedade empírica). A administração deve promover o desenvolvimento das soluções adequadas aos problemas que ocorrem na prática atual (a propriedade prática).

Ainda, eles ressaltam que, do mesmo modo que a possibilidade de governar adequadamente um Estado depende da harmonia entre as regulamentações e o comportamento da sociedade, a possibilidade de produzir a reconstrução analítica adequada depende de uma conexão entre a teoria a ser aplicada e a realidade argumentativa.

A reconstrução analítica desempenha, no estudo da argumentação, o papel de transformar o discurso, o que confirma a importância determinante, para uma teoria da argumentação, da confluência de pesquisas filosóficas, teóricas, empíricas e aplicadas. Obviamente, um programa de pesquisa no qual todos esses componentes sejam abordados pode somente ser desenvolvido 
em cooperação multidisciplinar, aliando os estudos filósofos e lógicos ao conhecimento dos linguistas e analistas do discurso e da comunicação.

\subsection{A Pragmadialética e as funções do estudo da argumentação}

Para os estudiosos da Pragmadialética, a argumentação é um fenômeno da comunicação verbal que deve ser estudado como um tipo específico de discurso para resolver uma diferença de opinião. Tal constituição discursiva deve ser observada por meio de um método de pesquisa que abranja tanto a dimensão descritiva quanto a normativa do discurso, e esse estudo não deve basear-se apenas na observação ou na idealização unilateral.

Para Van Eemeren e Grootendorst (2004), tanto as limitações da idealização não-empírica, baseada nos regimentos da Lógica moderna, quanto as limitações da observação não-crítica, exemplificada nas descrições da Linguística contemporânea, devem ser superadas sistematicamente, o que só pode acontecer por meio de um programa de pesquisa coerente, em que as dimensões descritiva e normativa estejam integradas.

Conforme vimos anteriormente, o programa da Pragmadialética ${ }^{41}$ foi formulado para atingir essa integração. Nele, a argumentação ampara-se em cinco premissas metateóricas ou metodológicas, no sentido de orientar a realização das pesquisas sobre sua constituição. A integração das teorias contemporâneas à Pragmadialética torna-se perceptível, já que cada premissa

\footnotetext{
${ }^{41}$ Conforme descrevemos anteriormente, vide página 93.
} 
representa um conceito delas derivado, justificando o caráter de convergência teórica, tão propagado por essa visão científica.

Nesse sentido, de acordo com essa teoria, as premissas precedentes levam a uma metodologia na pesquisa do processo de argumentar e discutir, conforme van Eemeren et al. (1996), composta pelos constituintes seguintes:

\subsubsection{Exteriorização:}

A Argumentação pressupõe, pragmaticamente, uma opinião e uma oposição a ela; envolve mais do que um processo de raciocínio pessoal e do que uma situação na qual duas partes tenham duas opiniões conflitantes. De modo a descobrir se suas opiniões serão aceitas, as pessoas as expõem à opinião pública, submetendo sua razoabilidade e raciocínio à análise dos outros por meio do discurso argumentativo. Por meio do comprometimento dos envolvidos no evento discursivo, apresentam-se no discurso todas as crenças, inferências, interpretações nas quais se sustenta a argumentação.

Deve-se ressalvar, entretanto, que um sujeito só pode estar comprometido com aquilo que efetivamente encontra-se em seu discurso, com sua posição/opinião realmente expressa por meio da linguagem. Em decorrência, qualquer tentativa de associar a argumentação a atitudes e crenças ou a uma simples exposição de um processo de raciocínio configura uma análise extremamente reducionista. Seu estudo deve apoiar-se nos comprometimentos discursivos, efetivamente, exteriorizados. 


\subsubsection{Socialização:}

Para tratar da importância do fator social da argumentação, em detrimento de uma leitura isolada dos argumentos, e do contexto situacional no momento da realização do evento discursivo, Van Eemeren (2009, p. 277) ressalta que:

(...) em teorias meramente preocupadas com o argumento "como produto", os argumentos são vistos tipicamente como a externalização do processo de pensamento individual, como elementos estruturais abstratos de racionalidade, como "premissa maior", "premissa menor" e "conclusão" dos processos comunicativos nos quais eles ocorrem. ${ }^{42}$

Por meio dessa afirmação, pode-se dizer que o autor critica a valorização exclusiva de elementos como premissa maior, premissa menor e conclusão no papel de validar a posição do interlocutor. Para ele, a argumentação não consiste no ato privado e individual de delinear uma conclusão, ela consiste em parte de um procedimento discursivo em que dois ou mais participantes com opiniões conflitantes pretendem chegar a uma conclusão. Nesse procedimento, há um interlocutor (protagonista) que interage dialogicamente de modo a responder às questões, dúvidas, objeções e reivindicações de outro interlocutor (antagonista).

Na visão da Pragmadialética, a argumentação e seu estudo não podem apoiar-se sobre uma perspectiva individualizada, e sim observar o contexto social do processo de resolver uma diferença de opinião. Cabe ressaltar que essa afirmação isenta a Pragmadialética de algumas das principais críticas a

${ }^{42}$ Tradução nossa de: " $(\ldots)$ in approaches merely concerned with argument "as a product" arguments typically are seen as na externalization of individual thougt processes, abstracting structural elements of reasoning such as "major premise", "minor premise" and "conclusion" from the communicative process in which they occur." 
essa teoria, as quais dizem respeito à pretensa deficiência na observação de elementos extrínsecos ao processo de argumentar.

\subsubsection{Funcionalidade:}

Para a Pragmadialética, os estudos clássicos derivados da Lógica Formal e Informal que observam a constituição dos argumentos e os estudos descritivos das falácias tendem a se preocupar exclusivamente com a descrição em termos estruturalistas da Argumentação e a ignorar sua função discursiva.

A necessidade de argumentar, de justificar, de antever as objeções e as dúvidas dos participantes do processo de argumentar decorre de um objetivo e, portanto, essas atitudes configuram-se como adaptáveis às situações em que ocorrem de modo a cumpri-lo, o que reflete na performação de diferentes atos de fala pelos interlocutores.

Assim, ao se descrever e analisar a argumentação, seu propósito deve ser levado em conta e sua função deve ser observada no evento verbal que pretende resolver a diferença de opinião. 


\subsubsection{Dialetificação ${ }^{43}$ :}

A argumentação configura-se como apropriada para resolver uma diferença de opinião apenas se for suficiente para responder às possíveis reações de um antagonista crítico; desse modo, uma teoria deve-se preocupar não só com a descrição da argumentação em suas inúmeras possibilidades de ocorrência, mas observar, também, se ela realmente pretende cumprir esse objetivo e, para isso, deve ser considerada como parte de um processo para resolver uma diferença de opinião.

Um procedimento dialético para discussões críticas possui validade dependendo do quão eficiente e eficaz ele é no sentido de alcançar essa resolução, excluindo movimentos falaciosos e sendo intersubjetivamente aceito pelos participantes. Van Eemeren (2009) destaca que um procedimento dialético válido torna possível determinar quando a condução do discurso argumentativo instrumentaliza a resolução da diferença de opinião.

Na Pragmadialética, segundo o autor (op. cit.), esses quatro passos são cumpridos por meio de elementos pragmáticos do discurso e elementos dialéticos da Filosofia e da Lógica: a exteriorização se cumpre por meio da identificação dos compromissos específicos criados pela performação dos atos de fala no contexto de controvérsia; alcança-se a socialização pela identificação dos papéis dos participantes envolvidos no discurso argumentativo em um contexto de interação colaborativo, o que destaca a necessidade das condições favoráveis para a performação de um ato de fala

\footnotetext{
43 Tradução nossa.
} 
que deixe claro a discordância do antagonista em relação à opinião do protagonista.

Já a funcionalidade ocorre quando há a identificação correta dos inúmeros atos de fala performados no discurso argumentativo. Por meio deles, torna-se claro qual o lugar da discordância que está envolvido no discurso e qual a função comunicativa e o propósito interacional de cada tipo de ato de fala, bem como o papel deles na resolução da diferença de opinião.

A dialetificação se configura por meio da análise, em uma idealização metodológica, das ocorrências de atos de fala direcionados a resolver a discordância. O modelo idealizado de discussão crítica serve como referência na análise e avaliação do discurso argumentativo. Esse conceito idealizado da atividade verbal, criado para definir as trocas sistemáticas de movimentos argumentativos orientados à resolução, explicita tanto a natureza quanto a distribuição dos atos de fala que podem desempenhar um papel fundamental em uma discussão crítica, podendo ser, assim, analisados.

Convém ressaltar que a argumentação só se configura em um modo de solucionar uma polêmica, se os interlocutores assim o desejarem, ou seja, se o antagonista expuser suas dúvidas e críticas, o que significa que a orientação teórica do texto ou discurso argumentativo deve respeitar as normas e os critérios que, de modo a serem úteis na resolução da diferença de opinião, deveriam ser utilizados na linguagem.

Para determinar-se em que extensão uma troca argumentativa resolve, de fato, a discordância, cria-se a necessidade de determinar certos padrões no 
uso da argumentação, bem como explicitar quando esses padrões constituemse adequados. Para tanto, cria-se, pela Pragmadialética, o modelo idealizado de discussão crítica, um dos conceitos da Pragmadialética que consideramos como altamente proveitoso, e absolutamente vital, para instrumentalizar nosso estudo, do qual tratamos a seguir.

\subsection{Modelo de discussão crítica}

O modelo de discussão crítica configura um aporte teórico para a definição de um procedimento de teste crítico às opiniões, de acordo com o compromisso assumido pelos interlocutores na realidade do discurso argumentativo. Esse modelo apresenta determinados estágios ou partes, distinguidos analiticamente no processo de solucionar a discussão. Ainda, cria uma relação desses estágios com os atos de fala, em que especifica quais modalidades de ato de fala possuem determinada função instrumental, em cada estágio da discussão crítica, para resolver uma diferença de opinião.

Diferentemente das teorias amparadas pela Lógica, o procedimento dialético para a condução das discussões críticas não se preocupa, exclusivamente, com as relações formais entre as premissas e as conclusões dos argumentos, mas sim com os atos de fala que ocorrem no discurso e que desempenham papéis na aceitabilidade das opiniões.

O modelo idealizado apresenta quatro estágios ou partes no processo de resolver a diferença de opinião, postos em prática pelos participantes de uma discussão argumentativa; entretanto, na prática, nem sempre se verifica a 
execução dessas partes (pode ocorrer de modo implícito); além disso, sua ordem, por vezes, não se mantém, porém, uma diferença de opinião só se resolverá adequadamente, para os preceitos da Pragmadialética, se cada estágio deste processo for cumprido, seja explícita ou implicitamente e de maneira linear. O modelo é composto dos seguintes estágios:

Confrontação: ocorre a apresentação do problema, como uma questão em debate ou uma discordância sobre um ponto de vista.

Abertura: determina-se se o acordo quanto à discussão é suficiente para a ocorrência de uma discussão produtiva; geralmente implícita no contexto de produção; as partes assumem seus papéis e determinam as bases para o acordo das regras, as condições de fechamento e os tipos de compromisso da discussão crítica.

Argumentacão: o protagonista expõe os argumentos favoráveis à sua opinião, os quais pretendem esclarecer as dúvidas ou refutar as críticas do antagonista, enquanto este analisa se considera o argumento aceitável ou não e realiza uma contra-argumentação.

Conclusão: avalia-se a tentativa de resolver a diferença de opinião, o que só ocorrerá, de fato, se as partes estiverem de acordo quanto à aceitabilidade da opinião do protagonista e se todas as dúvidas do antagonista forem esclarecidas ou se o protagonista retratar ou modificar a opinião inicial.

Esse modelo tem relação com outro conceito importante abordado pela Pragmadialética e que se refere à instauração das regras da discussão crítica, a partir de um código de conduta; estes fazem referência a um comportamento, 
ou ação, pelo qual os interlocutores são responsáveis, conforme discutiremos a seguir.

\subsection{Código de conduta para os participantes de uma discussão crítica}

As regras da Pragmadialética especificam em quais casos a performance de certos atos de fala contribui para resolver uma diferença de opinião e originam o Código de conduta para os participantes de uma discussão crítica, baseado nos critérios expressos no procedimento baseado na Pragmadialética para indivíduos, com base em um juízo de razoabilidade, dispostos a resolver sua diferença de opinião por meio da argumentação. Esse código consiste em uma listagem de dez movimentos prejudiciais ao processo de resolução da diferença de opinião:

1. Regra da liberdade- as partes não devem impedir-se de avançar no ponto de vista ou de questionar a opinião.

2. Regra da obrigação de defender- a parte que apresentar um ponto de vista não pode se recusar a defendê-lo.

3. Regra da opinião- o ataque de um ponto de vista de uma das partes não deve relacionar-se àquele que não fora, de fato, expresso pela outra parte.

4. Regra da relevância- a opinião não pode ser defendida por meio de nãoargumentação ou argumentação irrelevante.

5. Regra da premissa implícita- as partes não podem atribuir uma à outra, negar a responsabilidade pelas próprias premissas implícitas. 
6. Regra do ponto de partida- os participantes não podem apresentar falsamente ou negar que uma premissa represente um ponto de partida aceito.

7. Regra da validade- a razoabilidade que se apresenta como formalmente conclusiva na argumentação não deve ser invalidada em um sentido lógico.

8. Regra do esquema argumentativo- caso a defesa não seja feita por meio de um esquema argumentativo adequado e aplicado corretamente, um ponto de vista não deve ser considerado defendido conclusivamente por argumentação que não seja apresentada com base em um raciocínio formal conclusivo.

9. Regra do fechamento- a defesa inconclusiva da opinião não pode levar à manutenção dessa opinião, e a defesa conclusiva da opinião não pode resultar na permanência das expressões de dúvida concernentes a essa opinião.

10.Regra do uso da linguagem- as partes não devem usar quaisquer exposições ambíguas e não devem interpretar, deliberadamente, as afirmações da outra parte de maneira errônea.

Ressalta-se que esse código de conduta não se constitui em uma obrigatoriedade aos participantes da diferença de opinião; ele configura apenas um instrumento útil ao conceito de razoabilidade, mas que não tem a pretensão de levar, de forma lógica e invariável, ao mesmo resultado em todas as situações de uso do discurso. Ele é dependente da realidade argumentativa relativa ao contexto de ocorrência do evento discursivo. 
O não cumprimento de uma das regras do código de conduta pode originar um resultado que prejudique o alcance da resolução da diferença de opinião. Essas violações às regras podem ser consideradas uma falácia; outro conceito importante para a Pragmadialética, uma vez que apresenta uma definição específica.

De modo a realizar uma breve explanação acerca desse conceito, conforme proposto pela Pragmadialética, apresentamos o subitem a seguir.

\subsection{0 conceito de falácia na Pragmadialética ${ }^{44}$}

Para a Pragmadialética, uma falácia corresponde a uma violação às regras da discussão crítica que pode dificultar, ou mesmo impossibilitar, a resolução de uma diferença de opinião. Entende que sua ocorrência não se dá exclusivamente no terceiro estágio da discussão crítica (diálogo argumentativo): a argumentação. A razoabilidade do protagonista é testada em termos de quão adequados são os seus argumentos e esquemas argumentativos.

Assim, uma das afirmações mais importantes refere-se ao fato de que as falácias podem ocorrer em qualquer estágio da discussão crítica e que tanto o protagonista (aquele que expressa sua opinião no estágio de confrontação e que deve construir sua argumentação) quanto o antagonista (aquele que discorda e questiona a opinião inicial) podem cometê-las.

\footnotetext{
${ }^{44}$ Dedicamos o capítulo III de nosso trabalho ao estudo aprofundado desse conceito, sua especificidade nas diferentes teorias e sua particularidade na Pragmadialética.
} 
Esse conceito de falácia na Pragmadialética apresenta uma especificidade porque a relaciona, de modo explícito, ao processo de resolver a diferença de opinião. Certos casos que eram analisados como falácias, mas que não se encaixavam nos protótipos, poderão ser observados à luz da violação às regras, o que se aplica, em especial, às chamadas falácias informais $^{45}$.

As violações são realizadas por meio de atos de fala ou de atos de fala complexos, dos tipos assertivo, comissivo, diretivo, declarativo ou declarativo de uso. Outros tipos de violações que não sejam efetuadas por meio de atos de fala, mas por elementos não-verbais, podem interferir de modo fundamental ou não na resolução da diferença de opinião. Por exemplo, (VAN EEMEREN e GROOTENDORST, 2004, p. 164) "sacudir o punho ameaçadoramente é uma violação muito mais séria do que usar um gesto para adicionar força a uma declaração". Nesse caso, o ato não-verbal é uma violação à regra número 1, que prega o direito incondicional dos participantes de apresentarem ou questionarem uma opinião. O sujeito que a realizou é responsável por cometer uma falácia, por vezes difícil de ser detectada, denominada argumentum ad baculum, ${ }^{46}$ que se constitui em inibir, ou impossibilitar, a expressão da opinião de um indivíduo por meio da ameaça, seja física ou não.

Com exceção dos declarativos de uso, os atos de fala declarativos, bem como os expressivos, não fazem parte da discussão crítica. No que se refere aos declarativos, isso se dá por conta da necessidade inerente de uma

\footnotetext{
${ }^{45}$ Conceito relativo à Lógica Informal, que amplia a noção de falácia divulgada pela Lógica Formal.

${ }^{46}$ Trataremos desse e de outros tipos de falácia no Capítulo III.
} 
autoridade institucional extralinguística, e quanto aos expressivos, refere-se ao fato de que esses atos levam à pressuposição de verdade na proposição.

Ainda, os declarativos podem ser utilizados em um discurso ou texto para exercer uma espécie de pressão à outra parte (em várias escalas), e os expressivos servem para informar a respeito dos sentimentos de alguém em relação a certo aspecto da discussão. Em termos de violação, no uso do declarativo, teríamos novamente uma infração à regra número 1 , e no do expressivo, observaríamos a ocorrência de uma informação irrelevante à resolução da diferença de opinião, a menos que o expressivo em questão desempenhasse a função de um argumento, nesse caso o argumentum ad misericordiam, que pretende despertar a piedade da plateia, destaca-se que seu uso é falacioso quando o interlocutor a utiliza como modo de afirmar uma conclusão que não foi amparada por argumentos e provas.

Conforme observamos anteriormente, o conceito de falácia da Pragmadialética apresenta algumas especificidades, e nosso trabalho se propõe a analisá-lo, principalmente quanto a sua ocorrência no discurso político, especificamente, quando do acontecimento de um gênero de grande polêmica: o debate político eleitoral.

Nesse sentido, o exame das falácias, a partir dos preceitos da Pragmadialética, pode constituir-se em um meio auxiliar a esse processo de observar os elementos argumentativos de uma manifestação polêmica, abordagem específica de nosso terceiro capítulo, o qual tratará especificamente da constituição e caracterização das falácias. 


\section{Capítulo III -}

\section{Falácias - um percurso até os}

dias atuais 
O estudo das falácias constitui um campo profícuo e amplamente discutido, principalmente, nos estudos filosóficos e argumentativos desde os primeiros conceitos apresentados por Aristóteles. Ao buscarmos a literatura acerca do tema, encontramos inúmeras divergências tanto em sua definição de conceito, avaliação e estudo de seu funcionamento, quanto na classificação dos diferentes tipos que se apresentam.

A ocorrência da falácia pode se dar em quaisquer manifestações da linguagem, seja as pertencentes à linguagem do cotidiano, seja nos contextos mais institucionalizados e nas mais diferentes esferas. Verifica-se sua ocorrência quando os usuários da língua executam determinados movimentos dialógicos que podem ser classificados como injustos, incorretos ou inadequados por uma das partes. Pode ser detectada, por exemplo, a não apresentação do "ônus da prova", o ataque pessoal deslocado do contexto da situação discursiva, o auto-elogio, entre outros.

\subsection{De Aristóteles aos preceitos da Lógica Formal}

Os primeiros estudos sobre as falácias, segundo os estudos de van Eemeren; Garssen e Meuffels (2009), referem às obras de Aristóteles: Refutações Sofísticas, Primeiros Analíticos, Tópicos e Retórica. Esse grande pensador distingue dois grupos de falácias: aquelas ligadas ao uso da linguagem e o outro grupo que não se encontra dependente de tal uso. Para

os estudos que seguiram essa teoria, como a Lógica Formal, as falácias apresentam certa dificuldade em sua caracterização, pois eram analisadas em 
um caráter monológico, deixando o aspecto dialético, pensado por Aristóteles, em segundo plano.

Em sua obra Dialectica (a teoria do debate) Aristóteles descreve que refutar a tese de seu oponente constitui uma maneira de vencer um argumento; já na obra "De Sophisticis Elenchis", há uma compilação das principais espécies de falácias. Nesta obra, o autor discorre "sobre refutações conforme usadas pelos sofistas", sendo que a tradução inglesa influenciou a aproximação confusa entre os termos falácia e sofismo $^{47}$, atribuindo conotações pejorativas decorrentes da segunda à primeira.

As falácias remontam a variadas perspectivas teóricas que as analisam, algumas as condenam como exemplo de mau uso da linguagem, raciocínios incorretos dependentes de critérios estritamente lógicos e formais de validade e têm por objetivo extingui-las da linguagem em uso. Outras, em uma perspectiva mais contemporânea, procuram demonstrar que, por vezes, ela cumpre a função de um argumento válido ou que representa a ocorrência de um movimento discursivo que se caracteriza como uma violação de determinadas regras pré-estabelecidas que têm como propósito resolver uma diferença de opinião.

Destacam-se, como representantes atuais de diferentes linhas que procuram observar as falácias, os teóricos Blair e Johnson (1987/1993) e

\footnotetext{
47 Os sofistas, diferentemente de Aristóteles e Platão, acreditavam que não havia meios epistemológicos de encontrar a verdade e em decorrência dessa crença, pregavam que, em um debate, não é de fundamental importância qual dos participantes está agindo de acordo com os fatos da realidade, mas sim, quem de fato vence o argumento ou a argumentação. Instaurava-se, dessa forma, uma espécie de comercialização de habilidades, já que eles ofereciam treinamento e ensino àqueles que pudessem pagar o preço por eles exigido.
} 
Douglas Walton (1992/2006), da Lógica Informal, este último possui estudos dedicados a analisar os tipos de diálogos em que se dá sua ocorrência, van Eemeren e Grootendorst (1983), da Pragmadialética e Tindale (2007), que analisa esse conceito à luz da Retórica.

Santibáñez Yañes (2008) destaca que as perspectivas atuais no estudo das falácias apresentam análises e propostas específicas que as aproximam ou distanciam umas das outras. São exemplos de aproximação, citados pelo autor, o abandono da listagem padrão criada por Aristóteles e o acordo quanto à necessidade de uma teoria das falácias que observe determinados critérios epistemológicos. Dentre as diferentes perspectivas que observam as falácias, panoramas diversos delineiam-se: o estabelecimento de que elas constituem falhas de razoabilidade corriqueiras na fala, a necessidade de sua compreensão e entendimento dependentes de seu contexto (segundo Toulmin (1958), ligam-se ao campo da comunicação), os trabalhos que observam os estudos mais direcionados ao cognitivismo, sustentando que as falácias encontram-se na mente de seus intérpretes (Finocchiaro (1996)) ou, ainda, os estudos que observam as vantagens e desvantagens da explanação metodológica e didática dos métodos de identificar, classificar e avaliar as falácias para o desenvolvimento nos ambientes escolar e acadêmico em que seja desenvolvido o pensamento crítico (Blair, 1995).

Em razão de a base teórica de nosso trabalho constituir-se da Pragmadialética, é imprescindível citarmos van Eemeren e Houtlosser (2002) que afirmam a necessidade de um conceito claro de razoabilidade para uma teoria bem fundamentada das falácias. Na Pragmadialética, a instauração 
desse critério compreensível e explícito se dá com a criação prototípica e idealizada do conceito de discussão crítica, na qual as falácias caracterizam-se como movimentos argumentativos que violam as regras criadas para promover a resolução crítica de uma diferença de opinião.

Conforme exposto anteriormente, desde os estudos aristotélicos (384322) temos registros acerca das falácias (empíricos e teóricos). Algumas delas que conhecemos atualmente não constavam dos primeiros estudos desse pensador. Tratam-se das falácias conhecidas como "ad" e derivam da conceituação fornecida por John Locke (1603-1704): argumentum ad hominem, ad verecundiam, ad ignorantiam e ad judicium.

Sobre o argumentum ad hominem, pode-se dizer que sua ocorrência se dá quando houver o ataque pessoal, ou seja, desvia-se da opinião ou argumento discutido e atenta-se à figura do oponente. Mesmo que seja uma falácia geralmente utilizada com fins ludibriosos, ela tem em sua origem um status que possibilita sua ocorrência com fins não-pejorativos. É inevitável reconhecer que seus efeitos na audiência são enormes, mesmo que, por vezes, torne-se difícil traçarmos metodológica e epistemologicamente tais efeitos $^{48}$

Observando-se o conceito proposto por Locke, não se torna claro que ele considere o argumentum ad hominem uma falácia. A esse respeito, van Eemeren, Garssen e Meuffels (2009, p. 6) destacam:

\footnotetext{
${ }^{48}$ Essa afirmação decorre do fato da não realização de pesquisas que observem a audiência por meio de suas reações aos argumentos e falácias utilizados em um evento discursivo. Destacamos que, em nosso trabalho, em decorrência do gênero selecionado em nosso corpus, tal observação pode se relacionar ao resultado das eleições para prefeito de São Paulo.
} 
[...] pode ser valioso ou sábio refletir um pouco sobre quatro tipos de argumentos que os homens, ao raciocinar com outros, utilizam corriqueiramente para prevalecerem em relação ao acordo ou para conquistar a admiração dos outros e assim, silenciá-los. ${ }^{49}$

Dessa maneira, pode-se dizer que o filósofo não considera esse argumento como uma total falta de razoabilidade dos participantes; entretanto, atualmente, ele tem relação com o ataque pessoal direto a um oponente, depreciando-o e caracterizando-o como estúpido, mau ou não-confiável (variante abusiva) ou, indiretamente, levantando suspeitas sobre as motivações do oponente (variante circunstancial), ou apontando uma contradição nas palavras ou ações da outra parte (tu quoque).

Em relação aos outros tipos de falácia definidos por Locke (argumentum ad vericundiam e o argumentum ad ignorantiam), pode-se dizer que a falácia ocorrida no primeiro caso refere-se ao apelo equivocado à autoridade, o qual teria relação com a circunstância em que a audiência seria considerada arrogante se contrariasse a autoridade apresentada no argumento. Já no segundo caso, a falácia tem ligação com o ônus da prova no debate, pois configuraria uma maneira inaceitável de eximir-se da obrigação de fornecer argumentos, ao discordar da opinião de um interlocutor ou, ainda, conforme a concepção atual, relaciona-se ao apelo falacioso à ignorância ou à falta de provas, bem como ao fato de concluir que a não-comprovação de um fato é a definição de sua inexistência.

\footnotetext{
${ }^{49}$ Tradução nossa de: "[....] it may be worth our while to reflect a little on four sorts of arguments that men, in their reasoning with others, do ordinarily make use of to prevail on their assent or at least so to awe them as to silence their opposition."
} 
Outro conceito atribuído às falácias relaciona-se ao silogismo e aos argumentos indutivos. Essa perspectiva tem seu campo diretamente ligado aos estudos derivados da Lógica Formal e configura-se como "qualquer argumento, ou aparentemente um argumento, que promete ser decisivo no problema em questão, enquanto, na realidade, não o é." ${ }^{50}$ (VAN EEMEREN, GARSSEN, MEUFFELS, 2009, p. 8).

O modo como as falácias são tratadas nos livros contemporâneos de Lógica Formal apresenta uma grande divergência daquele proposto por Aristóteles. Isso se dá em decorrência da substituição da perspectiva dialética ou dialógica pela monológica, ou seja, para a Lógica Formal, com base mais normativa, as falácias constituiriam erros de razoabilidade, prescindindo da concepção que as compreende como manobras de um interlocutor tentando "iludir" ou distrair a outra parte e não levando em conta a necessidade de um interlocutor para constituir um evento discursivo no qual a falácia tem seu lugar.

Essa concepção normativa abandona a ideia aristotélica de debate e dialética como gênero responsável pelo aparecimento das falácias e, em decorrência desse fator, muitas vezes, a caracterização de determinado tipo de falácia torna-se difícil.

Outro teórico amplamente citado pelos autores que observam o campo das falácias é Hamblin (1993), que influenciou os estudos de Copi (1953), um dos estudiosos que tem seus trabalhos muito discutidos no Brasil; entretanto, pode-se dizer que sua perspectiva teórica encontra-se ligada a uma visão mais formal e normativa da linguagem e nosso estudo procura observar as

\footnotetext{
${ }^{50}$ Tradução nossa.
} 
abordagens mais contemporâneas que preconizam o espaço da dialogicidade e da pragmática em seus conceitos e, por isso, optamos por utilizar os conceitos que compõem a corrente da Lógica Informal e da Pragmadialética.

\subsection{As falácias na Lógica Informal}

Um dos grandes estudiosos da Lógica Informal é Douglas Walton (2006). Suas pesquisas abriram novos parâmetros no estudo das falácias, nas quais se observa o alinhamento dos estudos formais da Lógica, tornando-a subserviente à Dialética, aos conceitos da Pragmática, por meio da observação de casos individuais de falácias em ocorrências reais (com base em corpus e análise) e apresentando as devidas fundamentações teóricas.

De acordo com van Eemeren, Garssen e Meuffels (2009), em suas pesquisas recentes, Walton associa as falácias a mudanças dialéticas inaceitáveis de um tipo de diálogo a outro. Caso uma mudança no tipo de diálogo ocorra, um argumento que parece correto pode não ser adequado, ser inapropriado ou, ainda, pode constituir-se em um empecilho a esse novo tipo de diálogo. Ressaltamos que essa nova perspectiva explicita a importância do contexto situacional relativo aos tipos específicos de diálogo. De modo a exemplificar, o autor cita que um argumentum ad baculum, que apresenta uma ameaça velada, pode ser apropriado ${ }^{51}$ em uma negociação, mas altamente prejudicial em um diálogo persuasivo.

\footnotetext{
${ }^{51}$ No que se refere ao alcance de determinados efeitos no interlocutor.
} 
Os trabalhos de Walton (op. cit.) destacam a importância do tipo de diálogo na ocorrência das falácias, as quais representam uma perspectiva funcional e dialógica da argumentação razoável. De acordo com o tipo de diálogo, a legitimidade das falácias se constrói; por exemplo, em um diálogo persuasivo pode ser legítimo apelar para a emoção como modo de convencer o interlocutor; já em outros tipos, isso seria falacioso, cabendo à análise da argumentação observar em quais casos o apelo emocional serve como um artifício não-pertinente à disposição do interlocutor.

Para esse autor, as grandes compilações de tipos de falácias constituem argumentos razoáveis básicos que foram utilizados de modo inapropriado em uma estrutura particular e normativa de diálogo, envolvendo uma mudança de um tipo de diálogo a outro.

Walton (2006, p.26) fornece alguns exemplos dos tipos mais comuns de falácias ${ }^{52}$ :

a) Falácia das perguntas múltiplas: ocorre quando uma pergunta é feita de maneira agressiva, comprometendo o interlocutor com pressupostos anteriores. A estratégia baseia-se em levar oponente a se comprometer de modo prejudicial, causando uma possível derrota em sua argumentação. Tem relação com os implícitos na linguagem como, por exemplo, no caso clássico da pergunta "Você parou de bater na sua mulher?"

b) Falácia "ignoratio elenchi" ou falácia da conclusão não-pertinente, ou falácia de ignorância da questão: o argumento tem sua conclusão de

\footnotetext{
${ }^{52}$ Os exemplos são transcritos.
} 
maneira não pertinente e independentemente de sua validade, além de não tratar da questão em foco. $O$ interlocutor utiliza essa falácia porque carece de provas ou argumentos que provem sua tese e, assim, afastase da opinião em discussão.

c) Falácia argumentum ad baculum (apelo à força): relaciona-se à imposição da conclusão, sem argumentos que a sustentem, por meio da força ou da intimidação.

d) Falácias argumentum ad misericordiam e ad populum: relacionam-se às emoções da plateia. $O$ primeiro pretende despertar a piedade e considera-se que seu uso é falacioso quando o interlocutor as utiliza como forma de afirmar uma conclusão que não foi amparada por argumentos e provas pertinentes ao ônus da prova. Caracteriza uma forma de disfarce da argumentação fraca.

e) Falácia ad hominem: ocorre quando a crítica é dirigida pessoalmente ao interlocutor, em lugar de contra-argumentar em relação à opinião ou aos argumentos. Ressalta-se que, segundo Walton (2006), há casos em que a observação da conduta pessoal e das questões de caráter é pertinente ao se analisar uma argumentação e, por conta disso, não configurariam falácias. Essa falácia tem relação causal de uma mudança de um tipo de diálogo para outro como, por exemplo, no caso em que se discute acerca de uma investigação e muda-se para a exposição de opiniões políticas ou pessoais a respeito daquela pesquisa.

f) Falácia argumentum ad vericundiam (apelo à modéstia): ocorre quando um participante da discussão utiliza a opinião de uma autoridade como razão para fugir da necessidade de expor a própria opinião. Ressalta-se 
que o argumento de autoridade é uma maneira legítima de argumentar, mas que pode ser falacioso, se for mal empregado.

g) Falácia post hoc, ergo propter hoc: ocorre quando uma conclusão apresenta-se fundamentada apenas em uma relação causal entre dois acontecimentos. O exemplo citado pelo autor elucida melhor essa questão (op. cit., p. 30): "[...] embora possa haver uma correlação genuína entre a população de cegonhas e o índice de nascimentos (humanos) no norte da Europa, é um erro concluir que há uma relação causal entre as duas coisas." Por vezes, uma aproximação apressada pode utilizar uma coincidência como um argumento causal e, neste caso, configuraria uma falácia.

h) Falácia do argumentum ad ignorantiam: ocorre quando se define que algo é verdadeiro apenas porque não se pode provar sua falsidade ou vice-versa. Seria o caso de afirmar que Deus existe apenas porque ninguém conseguiu provar que ele não existe. Entretanto, apesar de ser um argumento fraco, o ad ignorantiam nem sempre é falacioso; isso depende do contexto de sua ocorrência. Essa relação com a razoabilidade decorre do ônus da prova.

i) Falácia do argumento circular ou petitio principii (petição de princípio): ocorre quando a conclusão derivada das duas premissas pode ser aceita pelo interlocutor apenas se ele acreditar nelas, ou seja, ela já está pressuposta nas premissas. Tem-se o exemplo do caso de uma discussão a respeito da existência de Deus em que um dos participantes apresenta um argumento baseado em duas premissas acerca das virtudes de Deus; entretanto, o outro participante já expôs sua 
incredulidade a esse respeito. Nessa situação, não há avanço na argumentação e ocorre a falácia que peca pelo princípio da argumentação, já que um dos interlocutores não crê no que está exposto na premissa inicial.

Esse estudo sobre as falácias, desenvolvido pela Lógica Informal, apresenta inovações teóricas e empíricas por possibilitar aos teóricos da argumentação uma nova maneira de analisar esse fenômeno, não mais amparado em estudos ad hoc e isolados das situações reais da linguagem, mas com uma base ligada à situação de uso da linguagem e que apresenta um caráter altamente funcional à classificação das falácias.

Mesmo que nossa pesquisa não esteja amparada nos preceitos dessa teoria, consideramos tal contributo à classificação das falácias uma grande ferramenta que pode possibilitar uma melhor compreensão desse fenômeno argumentativo e que nos será auxiliar no momento da análise do corpus que selecionamos.

\subsection{As falácias como uma violação a regras na visão Pragmadialética}

A Pragmadialética apresenta um conceito de falácia que apresenta especificidade única: ela consiste em "um ato de fala que constitui uma violação de uma ou mais das regras da discussão crítica", conforme van Eemeren (1983). Convém destacar o caráter inovador dessa concepção, totalmente diferenciada daquela trazida pelas outras vertentes que se ampararam nos trabalhos de Aristóteles e compreendiam a falácia, em uma 
perspectiva dialética ou não, como um raciocínio incorreto, um erro que acontece em um debate ou discussão.

A falácia consiste em uma violação às regras da discussão crítica, resumidas no Código de conduta $^{53}$ para os participantes de uma discussão crítica $^{54}$. As possíveis violações a essas regras definem-se como falácias, as quais se constituem em atos de fala que prejudicam ou acabam por extinguir os esforços para resolver uma diferença de opinião.

Ressalta-se que essa metodologia é aplicável apenas e na medida em que o discurso argumentativo seja de fato utilizado para resolver a discordância; entretanto, esse objetivo discursivo nem sempre é totalmente perceptível. Tal fato, segundo van Eemeren e Grootendorst, (1992) nos leva a uma análise metodológica que tenha o propósito de reconstruir a argumentação e observar as falácias no discurso.

Se as regras da discussão crítica fundamentam a definição de falácias, convém observar se sua aplicação torna-se necessária ou imprescindível, para que uma discordância seja resolvida com base no conceito de razoabilidade propagado pela Pragmadialética. Se observarmos a regra $1^{55}$, a regra da liberdade, é obvio que seu status configura-se como necessário, já que, se um dos participantes não permitir que o outro exponha sua opinião, a discussão não se configurará como crítica, no sentido idealizado, proposto pela teoria.

\footnotetext{
${ }^{53}$ Conforme exposto à página 105 do nosso trabalho.

54 Tradução nossa desse conceito abordado nas principais obras da Pragmadialética (van Eemeren e Grootendorst (1983, 2004) e Van Eemeren (2010).

${ }^{55}$ Conforme à página 105 do nosso trabalho.
} 
Conforme van Eemeren, Garssen e Meuffels (2009), há algumas maneiras de essa regra ser violada: um participante pode impor determinadas condições à exposição da opinião do outro ou negar-lhe o direito de criticá-la ou questioná-la, restringindo o seu conteúdo ou infringindo a liberdade pessoal. No segundo caso, isso pode ocorrer por meio de uma ameaça velada (ou não) ao interlocutor e, assim, caracterizar uma falácia do tipo ad baculum, ou ainda através do jogo com as suas emoções, levando-o a crer que, se questionar ou criticar a opinião, estará magoando ou constrangendo aquele que expressou a opinião inicial; neste caso, por restringir o direito de expressar a opinião ou criticá-la através da emoção ou da compaixão, a falácia ocasionada é considerada do tipo argumentum ad misericordiam.

Se a violação à regra número 1 ocorrer por meio de uma estratégia que descredencie a imparcialidade, integridade, credibilidade ou capacidade de um dos participantes, caracteriza-se a falácia do argumentum ad hominem.

Vemos, assim, que a perspectiva da Pragmadialética diferencia-se das teorias anteriores, que caracterizavam a falácia como tipos específicos listados em termos de estruturas e nomenclaturas, como erros ligados a apenas um único e mesmo critério de validade. Podemos dizer que a Pragmadialética oferece uma opção de análise sistemática das falácias tradicionais e torna possível observar de um modo novo os obstáculos ao processo de solução da discordância: as falácias individualizadas são explicadas por meio de violações a regras e não mais em um sentido ad hoc.

Conforme buscamos expor, o estudo das falácias que derivou das pesquisas de Aristóteles e deu origem à Lógica Formal, caracterizava-as, 
conforme já observamos, como argumentos inválidos ou instáveis, mas, para a Pragmadialética, constituem movimentos discursivos sem razoabilidade ocorridos em uma discussão crítica que devem ser vistos como violações a regras que ocorrem em determinados estágios da discussão.

Essas violações podem ocorrer em qualquer estágio, não só na argumentação; o que leva à necessidade do estabelecimento de uma metodologia que torne os estudos empíricos factíveis. A possibilidade de diferentes falácias terem lugar em qualquer estágio da discussão crítica torna necessária a explanação acerca de sua possível ocorrência em cada uma das partes dessa discussão crítica, conforme observamos a seguir.

\subsubsection{Violações das regras no estágio de confrontação}

De acordo com van Eemeren (2010), é no estágio da confrontação ${ }^{56}$ que as diferenças de opinião são apresentadas. A primeira regra do código de conduta proposto pela Pragmadialética determina que as opiniões podem referir-se a qualquer assunto, todas podem ser contestadas, todos podem apresentar suas opiniões e todos podem questioná-las. Como consequência dessa regra, nenhum participante da discussão pode impedir a outra parte, de qualquer maneira (verbal ou não-verbal), de exercer esse direito incondicional.

No estágio de confrontação, é possível que haja uma violação à regra que exige amplificações ou clarificações do protagonista sobre a opinião (ou a

\footnotetext{
${ }^{56}$ Conforme à página 104 de nosso trabalho.
} 
força de um ato de fala) ou vice-versa. Isso se deve ao fato de que, nesse estágio, é imprescindível a instauração real de uma diferença de opinião.

Ainda, é de suma importância que os participantes da discussão deixem clara a força comunicativa tanto de um ato de fala quanto da proposição (caso ambíguas), mas mesmo assim, pode ser difícil prevenir a ocorrência de falácias de ambiguidade.

\subsubsection{Violações das regras no estágio de abertura}

Conforme van Eemeren (2010), as regras 2 a 5 devem assegurar que as partes tentem resolver a diferença de opinião, uma vez que ela tenha sido devidamente instaurada. As violações das regras pertinentes a esse estágio têm como consequência a não-ocorrência do estágio de argumentação, seja porque o protagonista não foi desafiado pelo antagonista (regra 2), seja porque ele não aceitou o desafio (regra 3). É ainda necessário que a boa vontade para debater seja clara (regra 4) e que certas regras da discussão sejam acordadas (regra 5). A regulamentação do ônus da prova é importantíssima nos três primeiros casos. Caso o protagonista se furte à aplicação dessa regra, ele cometerá uma falácia do tipo argumentum ad ignorantiam.

Deve-se destacar que o acordo quanto às regras da discussão é uma condição indispensável para a caracterização da discussão crítica. 


\subsubsection{Violações das regras no estágio de argumentação}

As regras que têm relação com o estágio de argumentação $\left(6\right.$ a $\left.13^{57}\right)$ regulam o modo pelo qual a opinião inicial deve ser atacada e defendida, bem como em que casos esse ataque ou defesa foram conclusivos, conforme já observaram van Eemeren e Grootendorst (2004).

Em relação à força (de refutação ou justificação) de um ato de fala complexo, tanto o protagonista quanto o antagonista podem cometer violações à regra número 8 , que são comparáveis às violações com referência ao conteúdo proposicional. Destaca-se que esse fato difere da literatura sobre as falácias, que sempre dedicou maior atenção aos possíveis equívocos concernentes à força de se refutar ou justificar uma argumentação.

Esses raciocínios incorretos teriam tanto destaque que a "velha" definição de falácias baseava-se, exclusivamente, nessas situações. Além disso, geralmente, foca-se a atenção apenas no resultado do procedimento de inferência intersubjetivo, principalmente nos resultados negativos, o que acaba por tornar o protagonista o único responsável pelas falácias. A importância de se realizar o procedimento de explicitação intersubjetivo é, também, completamente ignorada.

O procedimento de explicitação intersubjetivo deve ser executado se o protagonista não apresentou o argumento total, mas apenas uma ou algumas partes da argumentação. A intenção do procedimento é levar à reconstrução das partes que não foram apresentadas.

\footnotetext{
${ }^{57}$ As regras de 11, 1213 e 14 referem-se àquelas que originaram o Código de conduta para os participantes da discussão crítica.
} 
Deve-se ressaltar que essa reconstrução precisa ser aceita pelas duas partes envolvidas na discussão, o que acaba por gerar uma espécie de acordo mútuo. Nesse caso, a ocorrência de dois tipos de violação- uma pelo protagonista e outra pelo antagonista torna-se propícia. A anterior acontece se a intervenção do antagonista avançar para algo além do argumento nãoexpresso pelo protagonista, pelo qual ele pode ser responsabilizado por conta de sua declaração ou outro ato de fala. Nesse caso, o antagonista cometeu a falácia de deturpar uma premissa não-expressa. Se a intervenção do protagonista significar que a reconstrução não alcança o argumento nãoexpresso, de sua responsabilidade, a violação refere-se à falácia de negar uma premissa não-expressa.

Ainda nesse estágio, o protagonista pode cometer violações à regra número 8 , que estejam relacionadas à escolha do esquema argumentativo dos seguintes modos: ele pode apresentar uma argumentação que esteja baseada em um esquema inaceitável pelo antagonista ou que não permita a reconstrução de um esquema argumentativo que estabeleça uma conexão entre o conteúdo proposicional da argumentação e a proposição apresentada na opinião inicial. Neste caso, ocorre uma não-argumentação, pois não há argumentação, e sim uma tentativa do protagonista de mostrar suas próprias qualidades ou tentar jogar com as emoções do antagonista. Ainda, pode ocorrer a argumentação irrelevante, em que há argumentação, mas não relacionada ao ponto questionado; neste caso, há a ocorrência da falácia ignoratio elenchi. 
Para van Eemeren e Grootendorst (2004), tanto o protagonista quanto o antagonista podem cometer violações à regra 8 , relacionadas à aplicação do esquema de argumentação escolhido. Por exemplo, o protagonista pode apresentar uma proposição que menciona certo evento e, então, derivar uma relação causal na proposição seguinte, em que um evento posterior é mencionado, mas não é, necessariamente, causado pelo evento mencionado no conteúdo proposicional da argumentação. Isso viola a regra 8, por apresentar uma sequência temporal como suficiente em vez de necessária para uma conexão causal. Nesse caso, há a ocorrência da falácia conhecida como post hoc ergo propter hoc.

Violações semelhantes ocorrem no caso das falácias do tipo secundum quid (uma generalização apressada na qual uma proposição universal é baseada sobre proposições singulares ou particulares que não sejam representativas ou suficientes) e do tipo ad consequentiam (um fato que consiste em uma suposição é usado para ser o caso em que se baseiam as consequências desejáveis ou indesejáveis mencionadas na proposição, ilustrando as consequências daquele fato).

Ainda o protagonista pode realizar uma falácia do tipo falácia da derrapagem ou bola de neve ${ }^{58}$, se apresentar uma proposição em que uma predicação é realizada sem motivação anterior e relacionada ao desejável ou indesejável na tomada ou não de determinada atitude e dali derivar uma proposição avaliativa, na qual afirma, como necessária, a adoção ou não dessa

\footnotetext{
${ }^{58}$ Em tradução nossa de: slippery slope.
} 
atitude. Por apresentar tal predicação como incontestável, o protagonista torna difícil ao antagonista expor questões críticas e às quais ele teria direito.

O antagonista poderá dificultar a correta aplicação de um esquema argumentativo aceito pelas partes, se utilizar incorretamente as questões críticas correspondentes ou que não tenham relação alguma com o esquema argumentativo. Por exemplo, se o protagonista utilizar um esquema argumentativo sintomático, o antagonista poderá solicitar a demonstração da relação causal entre o tópico representado no conteúdo proposicional da argumentação e na opinião, enquanto, na realidade, o protagonista apenas procura argumentar que o conteúdo proposicional da argumentação indica fortemente que o conteúdo proposicional da opinião está correto. Essas violações são exemplos da falácia nomeada de desvio da crítica ${ }^{59}$.

\subsubsection{Violações da regra no estágio de conclusão}

A única regra aplicável ao estágio de conclusão (regra 14) ${ }^{60}$ apresenta ao protagonista as consequências de um ataque conclusivo à opinião inicial pelo antagonista, e para este, as consequências de uma defesa conclusiva pelo protagonista. No primeiro caso, a consequência ao protagonista refere-se ao fato de ele ser obrigado a retratar a opinião inicial, e, no segundo caso, o antagonista deve retratar seu questionamento da opinião inicial.

\footnotetext{
${ }^{59}$ Em tradução nossa de: misplaced criticism.

${ }^{60}$ Essa regra não foi transcrita em nosso trabalho, ela origina a regra de fechamento (número 10) do Código de conduta para os participantes de uma discussão crítica.
} 
Essas são as únicas consequências deriváveis da regra que versa sobre a conclusão da discussão crítica. Se o protagonista perdeu a discussão, ele deverá retratar-se; entretanto, ele não estará obrigado a admitir que a opinião oposta foi provada, ou seja, defendida conclusivamente. $O$ antagonista que impuser essa consequência ao protagonista assume, incorretamente, que na discussão havia apenas duas únicas opiniões possíveis e, como a do protagonista foi atacada conclusivamente, que a opinião contrária teria sido defendida conclusivamente. Nesse caso, ele comete a falácia argumentum ad ignorantiam.

De modo a sumarizar alguns dos principais conceitos propostos pela Pragmadialética e a oferecer uma maior visibilidade das falácias possíveis em cada estágio da discussão crítica, passamos ao quadro ilustrativo proposto por van Eemeren e Grootendorst (1992, p. 209-211) que apresenta um panorama das violações prováveis das regras da discussão crítica e as consequentes falácias decorrentes de tal violação:

\subsection{As possíveis violações das regras da discussão crítica}

\begin{tabular}{|l|}
\hline $\begin{array}{l}\text { Violações da REGRA } 1 \text { pelo protagonista ou antagonista no estágio de } \\
\text { confrontação }\end{array}$ \\
\hline Referindo-se às opiniões: \\
\hline - declarar uma opinião como sacrossanta; \\
\hline • proibir opiniões. \\
\hline Referindo-se ao oponente: \\
\hline $\begin{array}{l}\text { - pressionar a outra parte por meio de suas emoções, pela compaixão ou } \\
\text { ameaçá-la com sanções. }\end{array}$ \\
\hline - atacando pessoalmente a outra parte: \\
A) caracterizando-a como estúpida, má, não confiável e etc.; \\
demonstrando suspeitar de suas motivações; \\
apontando uma inconsistência entre suas ideias e feitos no passado e/ou \\
presente. \\
\hline Violações da REGRA 2 pelo protagonista no estágio de abertura \\
\hline Fugir do ônus da prova por: \\
\hline
\end{tabular}


- apresentar a opinião como evidente por si só;

- dar uma garantia pessoal da exatidão da opinião;

- imunizar a opinião contra críticas.

Mudar o ônus da prova:

- em uma disputa não-mista, o antagonista deve mostrar que a opinião é incorreta;

- em uma disputa mista, apenas a outra parte deve defender sua opinião como um resultado do princípio presumido do critério de justiça.

Violações da REGRA 3 pelo protagonista ou antagonista, em todos os estágios da discussão em discussões mistas

Atribuir uma opinião não-real à outra parte:

- apresentar, com muita ênfase, o oposto da própria opinião;

- referir-se a visões do grupo ao qual alguém pertence;

- criar um oponente imaginário.

Distorcer a opinião da outra parte:

- descontextualizando as sentenças;

- simplificando ao extremo (ignorando nuances e qualificativos);

- exagerando (generalização e determinismo).

Violações da REGRA 4 pelo protagonista, no estágio de argumentação

A argumentação não se refere à opinião em discussão:

- argumentação irrelevante.

A opinião é defendida sem o uso da argumentação, mas por meio da persuasão não-argumentativa:

- jogando com as emoções da audiência;

- exaltando as qualidades próprias.

Violações da REGRA 5 pelo protagonista ou o antagonista, no estágio de argumentação

Negando uma premissa implícita (pelo protagonista);

Ampliando uma premissa implícita (pelo antagonista).

Violações da REGRA 6 pelo protagonista ou o antagonista no estágio de argumentação

Apresentar falsamente um ponto de partida como comum aos participantes (pelo protagonista):

- apresentar falsamente uma premissa como auto-evidente;

- implicar uma proposição em uma pressuposição;

- esconder uma premissa em uma premissa implícita;

- apresentar argumentação equivalente ao mesmo que fora expresso na opinião.

Negar uma premissa que represente um ponto de partida comum (pelo antagonista):

- duvidar de um ponto de partida aceito.

Violações da REGRA 7 pelo protagonista, no estágio de argumentação

Apoiar-se em um esquema argumentativo inapropriado:

- escolha inapropriada de argumentação sintomática;

- escolha inapropriada de argumentação por similaridade;

- escolha inapropriada de argumentação instrumental.

Utilizar um esquema argumentativo apropriado de modo incorreto:

- uso incorreto de argumentação sintomática;

- uso incorreto de argumentação por similaridade; 
- uso incorreto de argumentação instrumental.

Violações da REGRA 8 pelo protagonista no estágio de argumentação

Confundir condição necessária e condição suficiente

- uma condição necessária é tratada como suficiente;

- uma condição suficiente é tratada como necessária.

Confundir as propriedades do todo e das partes:

- uma propriedade relativa ou estrutura-dependente de um todo é atribuída a uma parte do todo;

- uma propriedade relativa ou estrutura-dependente de uma parte do todo é atribuída ao todo.

Violações da REGRA 9 pelo protagonista ou antagonista, no estágio de conclusão

Transformar em absoluto o sucesso da defesa (pelo protagonista):

- concluir que uma opinião é verdadeira porque ela foi defendida com sucesso.

Transformar em absoluto o fracasso da defesa (pelo antagonista):

- concluir que uma opinião é verdadeira porque a opinião contrária não foi defendida com sucesso.

Violações da REGRA 10 pelo protagonista ou antagonista em todos os estágios da discussão

Abusar da falta de clareza:

- falta de clareza estrutural;

- implícitos;

- indefinição;

- vagueza;

- estranhamento.

Abusar da ambiguidade:

- ambiguidade referencial;

- ambiguidade sintática;

- ambiguidade semântica.

Quadro 4- As violações às regras do Código de conduta para os participantes da discussão crítica.

Conforme o quadro precedente, as possíveis violações às regras da discussão crítica, sintetizadas no código de conduta, foram observadas pelas pesquisas realizadas com base nos conceitos da Pragmadialética. Ressalta-se que esse não é um procedimento prescritivo e sim um modelo baseado em estudos empíricos que visam a fornecer ferramentas para a análise do discurso argumentativo.

No próximo quadro, apresentado por van Eemeren e Grootendorst (1992, p. 212), observa-se como essas violações podem ser compreendidas 
em termos da nomenclatura tradicional das falácias, caracterizando um meio auxiliar ao processo de classificação e ilustração desse conceito:

\subsubsection{Falácias tradicionais como violações às regras da discussão crítica}

\begin{tabular}{|c|c|c|c|}
\hline FALÁCIA & $\begin{array}{l}\text { Regra } \\
\text { violada }\end{array}$ & $\begin{array}{l}\text { Estágio da } \\
\text { discussão } \\
\text { crítica da } \\
\text { possível } \\
\text { ocorrência }\end{array}$ & $\begin{array}{l}\text { Quem } \\
\text { comete } \\
\text { a } \\
\text { violaçã } \\
\text { o }\end{array}$ \\
\hline $\begin{array}{l}\text { 1-Afirmar a consequência: confusão entre } \\
\text { as condições suficiente e necessária. }\end{array}$ & 8 & 3 & $P^{61}$ \\
\hline $\begin{array}{l}\text { 2-Falácia da ambiguidade: uso indevido } \\
\text { da ambiguidade referencial, sintática ou } \\
\text { semântica. }\end{array}$ & 10 & $1-4$ & P./A. ${ }^{62}$ \\
\hline $\begin{array}{l}\text { 3-Argumentum ad baculum: pressionar a } \\
\text { outra parte por ameaçá-la com sanções. }\end{array}$ & 1 & 1 & P./A. \\
\hline $\begin{array}{l}\text { 4- Argumentum ad consequentiam: utilizar } \\
\text { um esquema argumentativo inapropriado } \\
\text { (causal) por rejeitar uma opinião descritiva } \\
\text { em razão de suas consequências } \\
\text { indesejadas. }\end{array}$ & 7 & 3 & $\mathrm{P}$. \\
\hline $\begin{array}{l}\text { 5-Argumentum ad hominem (ataque } \\
\text { pessoal direto e abusivo): duvidar da } \\
\text { inteligência, boa-fé e conhecimento da } \\
\text { outra parte. }\end{array}$ & 1 & 1 & P./A. \\
\hline $\begin{array}{l}\text { 6- Argumentum ad hominem (ataque } \\
\text { pessoal indireto e circunstancial): levantar } \\
\text { suspeitas sobre as motivações da outra } \\
\text { parte. }\end{array}$ & 1 & 1 & P./A. \\
\hline $\begin{array}{l}\text { 7-Argumentum ad hominem (tu quoque): } \\
\text { apontar inconsistências entre as ideias e } \\
\text { as ações da outra parte no passado e/ou } \\
\text { presente. }\end{array}$ & 1 & 1 & P./A. \\
\hline $\begin{array}{l}\text { 8-Argumentum ad ignorantiam: mudar o } \\
\text { ônus da prova em uma disputa não-mista } \\
\text { exigindo que o antagonista prove que a } \\
\text { opinião do protagonista está errada. }\end{array}$ & 2 & 2 & $\mathrm{P}$. \\
\hline $\begin{array}{l}\text { 9- Argumentum ad ignorantiam: tomar } \\
\text { como absoluta a falha da defesa por } \\
\text { concluir que a opinião é verdadeira }\end{array}$ & 9 & 4 & A. \\
\hline
\end{tabular}

\footnotetext{
${ }^{61}$ Protagonista.

${ }^{62}$ Antagonista.
} 


\begin{tabular}{|c|c|c|c|}
\hline $\begin{array}{l}\text { apenas porque o contrário não foi } \\
\text { defendido com sucesso. }\end{array}$ & & & \\
\hline $\begin{array}{l}\text { 10- Argumentum ad misericordiam: } \\
\text { pressionar a outra parte jogando com seus } \\
\text { sentimentos de compaixão. }\end{array}$ & 1 & 1 & P. \\
\hline $\begin{array}{l}\text { 11- Argumentum ad populum (variante de } \\
\text { ad vericundiam): usar um esquema } \\
\text { argumentativo inapropriado apresentando } \\
\text { a opinião como correta apenas porque } \\
\text { seria de senso comum. }\end{array}$ & 7 & 3 & $P$. \\
\hline $\begin{array}{l}\text { 12- Argumentum ad populum: defender a } \\
\text { opinião utilizando meios não } \\
\text { argumentativos de persuasão e jogar com } \\
\text { as emoções da audiência. }\end{array}$ & 4 & 3 & $P$. \\
\hline $\begin{array}{l}\text { 13- Argumentum ad verecundiam: utilizar } \\
\text { um esquema argumentativo inapropriado } \\
\text { (sintomático) apresentando a opinião } \\
\text { como correta porque uma autoridade a } \\
\text { ampara. }\end{array}$ & 7 & 3 & P. \\
\hline $\begin{array}{l}\text { 14- Falácia da composição: confundir as } \\
\text { propriedades das partes e do todo } \\
\text { atribuindo propriedade relativa ou } \\
\text { estrutura-dependente de uma parte do } \\
\text { todo ao todo. }\end{array}$ & 8 & 3 & $P$. \\
\hline $\begin{array}{l}\text { 15-Negação do antecedente: confundir as } \\
\text { condições necessária e suficiente, } \\
\text { tratando uma condição suficiente como } \\
\text { necessária. }\end{array}$ & 8 & 3 & P. \\
\hline $\begin{array}{l}\text { 16- Falácia da divisão: confundir as } \\
\text { propriedades da parte e do todo atribuindo } \\
\text { propriedade relativa ou estrutura- } \\
\text { dependente do todo a uma parte do todo. }\end{array}$ & 8 & 3 & P. \\
\hline $\begin{array}{l}\text { 17- Falsa analogia: utilizar o esquema } \\
\text { argumentativo da analogia de modo } \\
\text { incorreto por não preencher as condições } \\
\text { para uma comparação correta. }\end{array}$ & 7 & 3 & P. \\
\hline $\begin{array}{l}\text { 18- Ignoratio elenchi (argumentação } \\
\text { irrelevante): apresentar argumentação que } \\
\text { não se refere ao tópico em discussão. }\end{array}$ & 4 & 3 & $P$. \\
\hline $\begin{array}{l}\text { 19- Falácia das perguntas múltiplas: } \\
\text { apresentar falsamente um ponto de } \\
\text { partida em comum que contem uma } \\
\text { opinião implícita na perqunta. }\end{array}$ & 6 & 3 & P. \\
\hline $\begin{array}{l}\text { 20- Petitio principii (argumento circular): } \\
\text { apresentar falsamente algo como um } \\
\text { ponto de partida em comum que leva ao } \\
\text { mesmo que fora exposto no tópico em } \\
\text { discussão. }\end{array}$ & 6 & 3 & P. \\
\hline $\begin{array}{l}\text { 21-Post hoc ergo propter hoc: usar um } \\
\text { esquema } \quad \text { argumentativo } \quad \text { apropriado }\end{array}$ & 7 & 3 & P. \\
\hline
\end{tabular}




\begin{tabular}{|c|c|c|c|}
\hline $\begin{array}{l}\text { incorretamente por inferir uma relação de } \\
\text { causa e efeito da mera observação de } \\
\text { dois eventos subsequentes. }\end{array}$ & & & \\
\hline \begin{tabular}{lccr} 
22- & Secundum quid & \multicolumn{2}{c}{ (generalização } \\
apressada): & utilizar & o esquema \\
argumentativo & da & concomitância \\
incorretamente & por generalizar & sobre \\
observações & que & não & sejam \\
representativas ou suficientes. &
\end{tabular} & 7 & 3 & P. \\
\hline $\begin{array}{l}\text { 23- Repassar o ônus da prova } \\
\text { (argumentum ad ignorantiam): exigir que o } \\
\text { antagonista, em uma disputa não mista, } \\
\text { mostre que a opinião do protagonista está } \\
\text { errada. }\end{array}$ & 2 & 2 & $\mathrm{P}$. \\
\hline $\begin{array}{l}24 \text { - Repassar o ônus da prova: exigir que } \\
\text { apenas a outra parte defenda, em uma } \\
\text { disputa mista, sua opinião de acordo com } \\
\text { o Principio de presunção ou o Critério de } \\
\text { Justiça. }\end{array}$ & 2 & 2 & $\mathrm{P}$. \\
\hline $\begin{array}{l}\text { 25- Bola de neve: utilizar o esquema } \\
\text { argumentativo da causalidade (argumento } \\
\text { da consequência) incorretamente por } \\
\text { sugerir, equivocadamente, que em } \\
\text { decorrência de uma ação algo poderá ir } \\
\text { de mal a pior. }\end{array}$ & 7 & 3 & $\mathrm{P}$. \\
\hline $\begin{array}{l}\text { 26- Falácia do homem de palha: atribuir } \\
\text { uma opinião irreal ou distorcer a opinião } \\
\text { da outra parte. }\end{array}$ & 3 & $1-4$ & P./A. \\
\hline \multicolumn{4}{|c|}{$\begin{array}{l}\text { Itens que constituem outros obstáculos à resolução da discordância que } \\
\text { devem ser classificados como falácia por violarem a regras da } \\
\text { discussão: }\end{array}$} \\
\hline $\begin{array}{l}\text { 27- Declarar uma opinião como } \\
\text { sacrossanta. }\end{array}$ & 1 & 1 & P. \\
\hline $\begin{array}{l}\text { 28- Fugir do ônus da prova: imunizar a } \\
\text { opinião contra possíveis críticas. }\end{array}$ & 2 & 2 & $\mathrm{P}$. \\
\hline 29- Negar uma premissa implícita. & 5 & 3 & P. \\
\hline 30- Negar um ponto de partida aceito. & 6 & 3 & A. \\
\hline $\begin{array}{l}\text { 31- Apresentar falsamente um ponto de } \\
\text { partida comum. }\end{array}$ & 6 & 3 & P. \\
\hline $\begin{array}{l}\text { 32- Fugir do ônus da prova: apresentar } \\
\text { falsamente uma premissa como auto- } \\
\text { evidente. }\end{array}$ & 6 & 3 & P. \\
\hline $\begin{array}{l}\text { 33- Transformar em absoluto o sucesso } \\
\text { da defesa. }\end{array}$ & 9 & 4 & P. \\
\hline $\begin{array}{l}\text { 34- Falta de clareza estrutural, implícitos, } \\
\text { indefinição, vagueza, excesso de } \\
\text { cerimônia. }\end{array}$ & 10 & $1-4$ & P./A. \\
\hline
\end{tabular}

Quadro 5 - Falácias tradicionais e sua definição na Pragmadilética. 
Destacamos que o quadro comparativo, anteriormente exposto, proposto por van Eemeren (1992) resultou de observações empíricas que tiveram por objetivo a verificação da ocorrência de falácias como violações às regras da discussão crítica. Ao constatarmos tal procedimento, destaca-se a noção de teoria não prescritiva, baseada na empiria e preocupada com a apresentação de ferramentas que possibilitem um maior escrutínio da argumentação enquanto evento discursivo destinado a agir sobre os outros.

Ressalta-se que utilizaremos tal definição para proceder às nossas análises, como modo de instrumentalizar a aplicação teórica e metodológica em nosso corpus .

O avanço principal da Pragmadialética, no que se refere à teoria das falácias, consiste na sua classificação enquanto argumentos na forma de atos de fala e que, por violarem as regras, permitem sua caracterização como falácias, em situações particulares sempre ligadas ao contexto da ocorrência verbal.

A observação do contexto situacional constitui-se como essencial em termos da análise da argumentação. Em nosso caso, sua importância é ainda maior devido ao fato de o debate político eleitoral caracterizar-se como um gênero repleto de polêmica e constituir um campo profícuo à manifestação de estratégias e técnicas que buscam a manipulação da audiência, principalmente em relação aos sentimentos e emoções da plateia, em um jogo de afetos.

De modo a executar uma observação detalhada do debate político eleitoral, procederemos às análises, amparados pelos conceitos de discussão 
crítica e das falácias como atos de fala que constituem violações ao Código de conduta para os participantes dessa discussão. 


\section{Capítulo IV -}

\section{Análise do corpus}


Nossa análise relaciona-se ao conceito de falácias, conforme proposto pela Pragmadialética, e a sua ocorrência no debate político eleitoral. Nessa direção, entendemos que a aplicação do modelo de discussão crítica faz-se necessária, para que possamos observar a possível adequação da ocorrência específica das falácias em cada um dos estágios, de acordo com os preceitos dessa teoria.

\subsection{A análise}

Como ponto inicial, optamos por analisar o evento discursivo que ocorreu em 11 de setembro de 2008 e foi transmitido pela Rede Bandeirantes de Rádio e Televisão, por ocasião das eleições à Prefeitura da cidade São Paulo-SP.

O corpus foi transcrito segundo a norma do NURC-SP ${ }^{63}$ e os participantes foram indicador por L, em referência a locutor. Assim, L1: Boris Casoy (apresentador/ mediador e jornalista), além dos seguintes candidatos que concorreram à eleição para prefeito da cidade de São Paulo: L2: Ivan Valente (PSOL-PSTU), L3: Gilberto Kassab (DEM-PMDB-PR-PV-PSC-PRP), L4: Soninha Francine (PPS), L5: Renato Reichmann (PMN), L6: Marta Suplicy Suplicy (PT-PC do B-PSB-PDT-PRB-PTN), L7: Ciro Moura (PTC), L8: Geraldo Alckmin Alckmin (PSDB-PTB-PSL-PSDC-PHS), L9: Paulo Maluf (PP) e os jornalistas: L10: José Paulo de Andrade, L11: Fernando Vieira de Mello, L12: Sônia Blota, L13: Patrícia Zorzan, L14: Eudes Júnior e L15: Fernando Mitre.

63 Projeto: Estudo da norma urbana culta do estado de São Paulo, grupo sediado na Universidade de São Paulo. 
Conforme a Pragmadialética propõe, para a análise do discurso argumentativo, deve-se observar a adequação do evento discursivo - no caso, o debate político eleitoral - à idealização metodológica e empírica que se configura no modelo de discussão crítica, composto por quatro estágios específicos, de acordo com o exposto à página 104, do segundo capítulo.

Ao aplicarmos o modelo proposto ao debate selecionado, detectamos a ocorrência dos quatro estágios (confrontação, abertura, argumentação e conclusão); entretanto, conforme já havíamos destacado ser possível, essa estruturação não se dá de modo linear, de acordo com o desenvolvimento do evento discursivo, assim os segmentos apresentam a seguinte configuração:

- primeiro estágio - confrontação: ocorre após o estágio de abertura, no momento em que L1: Boris Casoy formula uma questão para ser respondida ou debatida por L2: Ivan Valente e, posteriormente, por L3: Glberto Kassab, L4: Soninha Francine, L5: Renato Reichmann, L6: Marta Suplicy, L7: Ciro Moura, L8: Geraldo Alckmin e L9: Paulo Maluf, conforme o segmento localizado às linhas 39 a 41, à p. 191 dos Anexos.

L1: (...) é a seguinte: ... QUAis as medidas conCREtas que serão TOmadas na sua administração para melhoRAR o TRÂNsito e o transporte coleTIvo na cidade?

- segundo estágio - abertura: ocorre antes do primeiro estágio. Entendemos que isso se deve ao fato de o evento discursivo sofrer a influência da esfera de atividade humana, conforme destacamos no segundo capítulo, que se constitui no discurso político, e por isso apresenta a estrutura 
composicional já estabilizada de acordo com a prática social referente à nossa cultura.

No gênero em questão, as partes participantes da discussão crítica deveriam ser informadas acerca de seus papéis, das regras e das condições do debate político eleitoral; de acordo com o que se observa no segmento seguinte, localizado às linhas 29 a 39 (p. 191 dos referidos Anexos), em que se explicitam as regras do debate " as regras do deBAte foram aprovadas pelos assessores de TOdos os candidatos...), os papéis dos participantes da discussão crítica (... uma perGUNta do mediador que será resPONdida por TOdos os candidatos em ordem já defiNIda por sorteio... tempo de UM minuto e me::io:: para a resposta.." e, até mesmo, as eventuais infrações (violações) que podem consistir em penalidades para os interlocutores "lembramos que durante o deBAte POde ser conCEdido direito de resposta em caso de ofensa moral ou pessoal... o pedido deve ser feito LOgo após a suPOsta ofensa... e a decisão de atender OU NÃO... será de uma comissÃO especialmente escolhida pela Band que se encontra em lugar reserVAdo nos bastidores....", conforme se observa a seguir:

L1: (...) ... as regras do deBAte foram aprovadas pelos assessores de TOdos os candidatos... vamos ver agora COmo será este pri-mei::ro bloco... uma perGUNta do mediador que será resPONdida por TOdos os candidatos em ordem já defiNIda por sorteio... tempo de UM minuto e me::io:: para a resposta... lembramos que durante o deBAte POde ser conCEdido direito de resposta em caso de ofensa moral ou pessoal... o pedido deve ser feito LOgo após a suPOsta ofensa... e a decisão de atender OU NÃO... será de uma comissÃO especialmente escolhida pela Band que se encontra em lugar reserVAdo nos bastidores... pela ordem do sorTElo já realizado na presença dos assessores... o candidato Ivan Valente será o primeiro a responder... eu lembro que o TEMpo para a resPOsta é de UM minuto e MElo... a pergunta foi escolhida a partir dos temas SUgeridos pelos leitores do jornal MEtro e é a seguinte: .. (....)

- terceiro estágio - argumentação: configura o estágio mais profícuo da discussão e ocorre no momento em que os participantes/candidatos 
começam a direcionar perguntas a seus oponentes, conforme o segmento localizado às linhas de 05 à 10 (página 195):

L6: é... minha pergunta é para Geraldo Alckmin... no seu governo... Alckmin... São Paulo viveu a pior CRlse de segurança... foram centenas de rebeliões na FeBEM... CHAcinas... e nós vivemos uma situação trágica com o Pcc... nessa época o seu PARtido não ajudou... pois extinguiu a secretaria de segurança da cidade de São Paulo... e suCAteou a GUARda municipal... a minha pergunta é... QUAL a sua posição sobre a atitude do seu partido na prefeiTUra?... o que você pretende fazer com a GUARda na cidade de São Paulo?...

A partir dessa pergunta de L6, observa-se que os participantes começam a debater diretamente e propiciam a ocorrência das falácias, o que configura o próximo item de nossa análise. Inclui-se, ainda, o quarto estágio da discussão crítica, conclusão, que também é observado no corpus .

- quarto estágio - conclusão: nesse estágio, avalia-se a tentativa de resolver a diferença de opinião; entretanto, de acordo com definição da Pragmadialética, a qual apregoa que uma discussão só é concluída adequadamente quando todas as dúvidas do antagonista forem esclarecidas ou quando o protagonista modificar sua opinião inicial, não foi observada no corpus sob análise. A conclusão se dá devido a fatores externos, decorrentes do contexto situacional, que constituíram uma limitação no tempo do debate político eleitoral, observável por conta da performação de um ato de fala diretivo indireto por parte do mediador L1, localizado à linha 27 da página 221, o qual, investido de autoridade, explicita que os participantes têm apenas dois minutos para suas considerações finais e, assim, depreende-se que eles devem encerrar o debate. Destaca-se que esse estágio, no debate político eleitoral, sofrerá as coerções relacionadas ao propósito comunicacional desse evento discursivo. 
L1: neste bloco cada candidato terá DOIS minutos para fazer as considerações finais (...) - (linha 27 - página 221 - Anexo1)

Procedemos à análise dos estágios da discussão crítica de modo a aplicar os conceitos da Pragmadialética e a observar se as falácias que localizamos a seguir ocorrem, efetivamente, no estágio da discussão crítica que a Pragmadialética propõe:

\begin{tabular}{|l|l|l|l|}
\hline FALÁCIA & $\begin{array}{l}\text { Regra } \\
\text { violada }\end{array}$ & $\begin{array}{l}\text { Estágio da } \\
\text { discussão } \\
\text { crítica da } \\
\text { possível } \\
\text { ocorrência }\end{array}$ & $\begin{array}{l}\text { Quem } \\
\text { comete } \\
\text { a } \\
\text { violaçã } \\
\text { o }\end{array}$ \\
\hline $\begin{array}{l}\text { 1-Afirmar a consequência: confusão entre } \\
\text { as condições suficiente e necessária. }\end{array}$ & 8 & 3 & P. \\
\hline $\begin{array}{l}\text { 2-Falácia da ambiguidade: uso indevido da } \\
\text { ambigüidade referencial, sintática ou } \\
\text { semântica. }\end{array}$ & 10 & $1-4$ & P./A. \\
\hline $\begin{array}{l}\text { 3-Argumentum ad baculum: pressionar a } \\
\text { outra parte por ameaçá-la com sanções. }\end{array}$ & 1 & 1 & P./A. \\
\hline $\begin{array}{l}\text { 4- Argumentum ad consequentiam: utilizar } \\
\text { um esquema argumentativo inapropriado } \\
\text { (causal) por rejeitar uma opinião descritiva } \\
\text { em razão de suas consequências } \\
\text { indesejadas. }\end{array}$ & 7 & 3 & P. \\
\hline $\begin{array}{l}\text { 5-Argumentum ad hominem (ataque pessoal } \\
\text { direto e abusivo): duvidar da inteligência, } \\
\text { boa-fé e conhecimento da outra parte. }\end{array}$ & 1 & 1 & \\
\hline $\begin{array}{l}\text { 6- Argumentum ad hominem (ataque } \\
\text { pessoal indireto e circunstancial): levantar } \\
\text { suspeitas sobre as motivações da outra } \\
\text { parte. }\end{array}$ & 1 & 1 & P./A. \\
\hline $\begin{array}{l}\text { 7-Argumentum ad hominem (tu quoque): } \\
\text { apontar inconsistências entre as ideias e as } \\
\text { ações da outra parte no passado e/ou } \\
\text { presente. }\end{array}$ & 1 & 1 & P./A. \\
\hline $\begin{array}{l}\text { 8-Argumentum ad ignorantiam: mudar o } \\
\text { ônus da prova em uma disputa não-mista } \\
\text { exigindo que o antagonista prove que a }\end{array}$ & 2 & 2 & \\
\hline
\end{tabular}

\footnotetext{
${ }^{64}$ Protagonista.

${ }^{65}$ Antagonista.
} 


\begin{tabular}{|c|c|c|c|}
\hline opinião do protagonista está errada. & & & \\
\hline $\begin{array}{l}\text { 9- Argumentum ad ignorantiam: tomar como } \\
\text { absoluta a falha da defesa por concluir que } \\
\text { a opinião é verdadeira apenas porque o } \\
\text { contrário não foi defendido com sucesso. }\end{array}$ & 9 & 4 & A. \\
\hline $\begin{array}{l}\text { 10- Argumentum ad misericordiam: } \\
\text { pressionar a outra parte jogando com seus } \\
\text { sentimentos de compaixão. }\end{array}$ & 1 & 1 & $\mathrm{P}$. \\
\hline $\begin{array}{l}\text { 11- Argumentum ad populum (variante de } \\
\text { ad vericundiam): usar um esquema } \\
\text { argumentativo inapropriado apresentando a } \\
\text { opinião como correta apenas porque seria } \\
\text { de senso comum. }\end{array}$ & 7 & 3 & P. \\
\hline $\begin{array}{l}\text { 12- Argumentum ad populum: defender a } \\
\text { opinião utilizando meios não argumentativos } \\
\text { de persuasão e jogar com as emoções da } \\
\text { audiência. }\end{array}$ & 4 & 3 & P. \\
\hline $\begin{array}{l}\text { 13- Argumentum ad verecundiam: utilizar } \\
\text { um esquema argumentativo inapropriado } \\
\text { (sintomático) apresentando a opinãa como } \\
\text { correta porque uma autoridade a ampara. }\end{array}$ & 7 & 3 & P. \\
\hline $\begin{array}{l}\text { 14- Falácia da composição: confundir as } \\
\text { propriedades das partes e do todo } \\
\text { atribuindo propriedade relativa ou estrutura- } \\
\text { dependente de uma parte do todo ao todo. }\end{array}$ & 8 & 3 & P. \\
\hline $\begin{array}{l}\text { 15-Negação do antecedente: confundir as } \\
\text { condições necessária e suficiente, tratando } \\
\text { uma condição suficiente como necessária. }\end{array}$ & 8 & 3 & P. \\
\hline $\begin{array}{l}\text { 16- Falácia da divisão: confundir as } \\
\text { propriedades da parte e do todo atribuindo } \\
\text { propriedade relativa ou estrutura- } \\
\text { dependente do todo a uma parte do todo. }\end{array}$ & 8 & 3 & P. \\
\hline $\begin{array}{l}\text { 17- Falsa analogia: utilizar o esquema } \\
\text { argumentativo da analogia de modo } \\
\text { incorreto por não preencher as condições } \\
\text { para uma comparação correta. }\end{array}$ & 7 & 3 & P. \\
\hline $\begin{array}{l}\text { 18- lgnoratio elenchi (argumentação } \\
\text { irrelevante): apresentar argumentação que } \\
\text { não se refere ao tópico em discussão. }\end{array}$ & 4 & 3 & $\mathrm{P}$. \\
\hline $\begin{array}{l}\text { 19- Falácia das perguntas múltiplas: } \\
\text { apresentar falsamente um ponto de partida } \\
\text { em comum que contem uma opinião } \\
\text { implícita na pergunta. }\end{array}$ & 6 & 3 & P. \\
\hline $\begin{array}{l}\text { 20- Petitio principii (argumento circular): } \\
\text { apresentar falsamente algo como um ponto } \\
\text { de partida em comum que leva ao mesmo } \\
\text { que fora exposto no tópico em discussão. }\end{array}$ & 6 & 3 & P. \\
\hline $\begin{array}{l}\text { 21- Post hoc ergo propter hoc: usar um } \\
\text { esquema argumentativo apropriado } \\
\text { incorretamente por inferir uma relação de } \\
\text { causa e efeito da mera observação de dois } \\
\text { eventos subsequentes. }\end{array}$ & 7 & 3 & P. \\
\hline
\end{tabular}




\begin{tabular}{|c|c|c|c|}
\hline \begin{tabular}{lcr}
$22-$ & Secundum quid & \multicolumn{2}{c}{ (generalização } \\
apressada): & utilizar & or esquema \\
argumentativo & da & concomitância \\
incorretamente & por generalizar sobre \\
observações que não sejam representativas \\
ou suficientes.
\end{tabular} & 7 & 3 & P. \\
\hline $\begin{array}{l}\text { 23- Repassar o ônus da prova (argumentum } \\
\text { ad ignorantiam): exigir que o antagonista, } \\
\text { em uma disputa não mista, mostre que a } \\
\text { opinião do protagonista está errada. }\end{array}$ & 2 & 2 & P. \\
\hline $\begin{array}{l}24 \text { - Repassar o ônus da prova: exigir que } \\
\text { apenas a outra parte defenda, em uma } \\
\text { disputa mista, sua opinião de acordo com o } \\
\text { Principio de presunção ou o Critério de } \\
\text { Justiça. }\end{array}$ & 2 & 2 & P. \\
\hline $\begin{array}{l}\text { 25- Bola de neve: utilizar o esquema } \\
\text { argumentativo da causalidade (argumento } \\
\text { da consequência) incorretamente por } \\
\text { sugerir, equivocadamente, que em } \\
\text { decorrência de uma ação algo poderá ir de } \\
\text { mal a pior. }\end{array}$ & 7 & 3 & $\mathrm{P}$. \\
\hline $\begin{array}{l}\text { 26- Homem de palha: atribuir uma opinião } \\
\text { irreal ou distorcer a opinião da outra parte. }\end{array}$ & 3 & $1-4$ & P./A. \\
\hline \multicolumn{4}{|c|}{$\begin{array}{l}\text { Itens que constituem outros obstáculos à resolução da discordância que } \\
\text { devem ser classificados como falácia por violarem a regras da discussão: }\end{array}$} \\
\hline $\begin{array}{l}\text { 27- Declarar uma opinião como } \\
\text { sacrossanta. }\end{array}$ & 1 & 1 & P. \\
\hline $\begin{array}{l}\text { 28- Fugir do ônus da prova: imunizar a } \\
\text { opinião contra possíveis críticas. }\end{array}$ & 2 & 2 & $\mathrm{P}$. \\
\hline 29- Negar uma premissa implícita. & 5 & 3 & P. \\
\hline 30- Negar um ponto de partida aceito. & 6 & 3 & A. \\
\hline $\begin{array}{l}\text { 31- Apresentar falsamente um ponto de } \\
\text { partida comum. }\end{array}$ & 6 & 3 & $\mathrm{P}$. \\
\hline $\begin{array}{l}\text { 32- Fugir do ônus da prova: apresentar } \\
\text { falsamente uma premissa como auto- } \\
\text { evidente. }\end{array}$ & 6 & 3 & $\mathrm{P}$. \\
\hline $\begin{array}{l}\text { 33- Transformar em absoluto o sucesso da } \\
\text { defesa. }\end{array}$ & 9 & 4 & P. \\
\hline $\begin{array}{l}\text { 34- Falta de clareza estrutural, implícitos, } \\
\text { indefinição, vagueza, excesso de cerimônia. }\end{array}$ & 10 & $1-4$ & P./A. \\
\hline
\end{tabular}

Quadro 6 - Falácias tradicionais e sua definição na Pragmadialética.

De acordo com a classificação de falácias proposta pela Pragmadialética, indicada no terceiro capítulo, por meio de um ato de fala, o 
participante da discussão crítica que desempenha o papel de protagonista pode realizar, no estágio da argumentação, uma violação à regra número quatro: "Regra da relevância" e originar uma falácia do tipo ad populum - a qual apela a sentimentos populares ou entusiasmo da coletividade com o intuito de levar a uma conclusão que não se sustenta em provas.

Observamos sua realização no seguinte segmento do corpus, no qual L8, Geraldo Alckmin, apresenta um argumento amparado na exemplificação de uma situação isolada, em que se apoia na palavra de um jovem estudante carente para apelar à emoção da coletividade que poderia se solidarizar com ele e partilhar de suas opiniões, embora não apresente provas: "fico feliz quando jovem me encontra e diz olha... estudei na ETEC... estudei na FATEC... entrei na USP Leste... vou de trem pra USP Leste... éh... dos hospitais... dizer olha... eu pude estudar porque entrei na Escola da Família então fiz a faculdade de graça.", conforme localizado às linhas 5 a 14 da página 222 :

L8: (...) cuidei dos SEIS-CEN-TOS E QUA-REN-TA e CINCO municípios do estado de São Paulo... parcerias... convênios... um conjunto de trabalhos... inclusive aqui em São Paulo... obras importantíssimas... a USP Leste... fico feliz quando jovem me encontra e diz olha... estudei na ETEC... estudei na FATEC... entrei na USP Leste... vou de trem pra USP Leste... éh... dos hospitais... dizer olha... eu pude estudar porque entrei na Escola da Família então fiz a faculdade de graça... resolvemos o problema do Tietê... que desafiava décadas o problema das enchentes na Marginal do Tietê... o CarandiRU... que parecia uma coisa insolúvel... hoje só no filme do Hector Babenco... trabalhamos em todas as áreas... e eu peço o seu voto... pra poder me dedicar a essa nossa cidade... a essa cidade que (...)

Ainda, também no terceiro estágio, encontra-se a realização de outra violação à regra número quatro, relacionada à relevância do argumento em relação ao tópico em discussão, conforme item 18 do quadro precedente (página 142), proposto pela Pragmadialética. Essa violação ocorre por meio de 
um ato de fala do tipo expressivo (leva à pressuposição de verdade na proposição ou serve para informar a respeito dos sentimentos de alguém em relação a certo aspecto da discussão) que gera a falácia ignoratio elenchi.

Observamos essa falácia no ato de fala performativo de L6: Marta Suplicy, conforme segmento localizado às linhas de 31 a 33 (página 195), em que expressa seus sentimentos de incredulidade, com o uso do termo "me espanta", em relação ao tópico colocado em discussão por seu oponente, Geraldo Alckmin, no qual este salientava que, na administração de seu partido, o PSDB, os índices de criminalidade registravam uma queda na cidade de São Paulo:

L6: me espanta a resposta porque parece que nós vivemos em cidades diferentes... em realidades diferentes... na sua época Alckmin... as crianças a maior índice de mortalidade de DEZ a quarenta e nove anos foi homiCÍDIO (...)

(linhas 31 a 33- página 195 )

$\mathrm{Na}$ ocorrência de uma falácia ad hominem, encontramos, em nosso corpus, uma variação do que propõe a Pragmadialética. De acordo com o quadro proposto pela Pragmadialética, no item 5- que caracteriza um ataque pessoal abusivo, duvidando da boa-fé da outra parte, essa violação à regra número 1, "regra da liberdade", teria lugar no primeiro estágio da discussão crítica e não no terceiro, conforme foi verificado em nosso corpus .

Em nossa análise, entendemos que L6, Marta Suplicy, comete tal falácia ao caracterizar o adversário, Geraldo Alckmin, como uma fonte não-confiável: “os números/ que você falou não são os números verdadeiros...", exercendo uma censura que o cala, ao mesmo tempo em que apresenta um argumento válido e de 
grande força argumentativa, o argumentum ad verecundiam, pois seus dados seriam, na realidade, confiáveis por apresentarem uma fonte de credibilidade ( o Supremo Tribunal Federal): "os meus foram inclusive reconfirMADOS pelo Supremo Tribunal Federal", conforme o segmento localizado à página 196, linhas 50 a 54:

L6: Alckmin eu não vou ficar discutindo os números com você porque os números/_que você falou não são os números verdadeiros... então vai ficar os meus contra os SEUS... né?... os meus foram inclusive reconfirMADOS pelo Supremo Tribunal Federal e foi feito um clima de terror eXATAmente para colocar a nossa administração com uma MÁ face (....)

O segundo evento discursivo que analisamos refere-se ao debate político ocorrido em 12 de outubro de 2008, com duração de cento e dezenove minutos e quarenta segundos, e transmitido pela Rede Bandeirantes de Rádio e Televisão, em decorrência das eleições à Prefeitura da cidade São Paulo-SP.

Os interlocutores são: L1: Boris Casoy (mediador), L2: Marta Suplicy, L3: Glberto Kassab (políticos convidados) e L4: Fernando Vieira de Mello, L5: José Paulo de Andrade, L6: Sérgio Gabriel, L7: Patrícia Zorzan e L8: Fernando Mitre (jornalistas convidados).

Ao observarmos a estruturação da discussão crítica em quatro estágios, detecta-se que o - primeiro estágio - confrontação: observável no turno seguinte de L1: "em CAso de viTÓria nesta eleição... o senhor ou a senhora se compromete a cumprir INTEGRALmente o seu mandato?... por ordem de sorteio... a candidata MARta Suplicy é a primeira a responder...", ocorre quase simultaneamente ao segundo estágio- a abertura, no turno de L1: “... vamos ver aGOra como será este PRI-mei-ro bloco... (... ) mediador será respondida pelos dois candidatos em ordem já definida por sorteio... o tempo para a resposta é de DOis minutos... na seQUÊncia... CANdidato pergunta para candiDAto... um minuto para a pergunta... DOis minutos para a resposta... réplica e 
tréplica de UM minuto cada... vamos aGOra... à pergunta...", conforme o segmento localizado às linhas 19 a 37 da página 226:

L1: boa noite... começa aGOra o PRImeiro debate entre os candiDAtos à prefeiTUra de SÃO PAUlo neste seGUNdo turno... com este encontro a Band reforça MAis uma vez sua tradição de esTImular a discussão de propostas e ideias dos fuTUros governantes... hoje frente a frente nos nossos estúdios estão a candidata Marta Suplicy dos Pt... e o candidato GilBERto Kassab do Dem... na plateia... convidados dos partidos.... autoridades e jornalistas... estão conosco nesta transmissão ao Vlvo... a Band News TV... as rádios BANdeirantes $\mathrm{Am}$ e $\mathrm{Fm}$ e a Band News $\mathrm{Fm} \ldots$ o debate também será TRANSmitido pela internet no band.com.br... vamos ver aGOra como será este PRI-mei-ro bloco... ( ) mediador será respondida pelos dois candidatos em ordem já definida por sorteio... o tempo para a resposta é de DOis minutos... na seQUÊncia... CANdidato pergunta para candiDAto... um minuto para a pergunta... DOis minutos para a resposta... réplica e tréplica de UM minuto cada... vamos aGOra... à pergunta... antes eu vou lembrar que em caso de oFENsa moral ou pessoal pode ser concedido DIRElto de resposta a critério de uma comissão formada espeCIALmente para esse fim... a pergunta a que me referi... escolhida a partir de sugestões dos leitores do jornal Metro é a seguinte... em CAso de viTÓria nesta eleição... o senhor ou a senhora se compromete a cumprir INTEGRALmente o seu mandato?... por ordem de sorteio... a candidata MARta Suplicy é a primeira a responder...

Vemos que o debate político eleitoral, em nosso corpus, parece estar constituído de modo similar à classificação dos estágios da discussão crítica (confrontação, abertura, argumentação e conclusão); entretanto, não linearmente e nem de maneira explícita, o que pode encaminhar para o fato de o debate político eleitoral sofrer as consequências da caracterização do gênero em seu contexto social e cultural.

Já o terceiro estágio - argumentação - ocorre no momento em que os participantes/candidatos começam a direcionar perguntas a seus oponentes: o candidato Gilberto Kassab formula uma pergunta à candidata Marta Suplicy: “ ... a pergunta que the faço é... POR que na sua gestão as áreas pavimentadas foram TÃO insignificantes... por que foram TÃO pouco pavimentadas na sua gestão?", conforme o segmento localizado à página 227, linhas 40 a 47: 
L3: candidata Marta... na nossa gestão... demos sequência a um projeto... a um programa de REcapeamento e pavimentação que nunca tinha acontecido na cidade antes... TRIplicamos o volume pavimentado na cidade de São Paulo... eh... QUAdruplicamos o que foi recapeado... cuidamos melhor da cidade e... Evidentemente isso trouxe uma SÉrie de benefícios... principalmente para a população mais humilde da cidade de São Paulo... a pergunta que the faço é... POR que na sua gestão as áreas pavimentadas foram TÃO insignificantes... por que foram TÃO pouco pavimentadas na sua gestão?

Observa-se que, novamente, o quarto estágio - conclusão- é realizado sem que os participantes cheguem a uma opinião reformulada ou a um acordo e sim em decorrência do ato de fala realizado pelo mediador do debate: " e termina aqui o primeiro encontro desse segundo turno... entre os candidatos à prefeitura de São Paulo..”, de acordo com o segmento localizado às linhas 44 a 50 da página 227:

L1: e termina aqui o primeiro encontro desse segundo turno... entre os candidatos à prefeitura de São Paulo... eu gostaria de agradecer... às presenças dos candidatos Gilberto Kassab e Marta Suplicy... e a BAnd escreve assim... MAis um capítulo de sua LONga história na realização de debates políticos... e logo após o terceiro tempo... o Canal Livre especial vai discutir a campanha eleitoral e avaliar os deBAtes de hoje... em SÃO Paulo Belo Horizonte e Rio de Janeiro... eleiçÕES dois mil e oito... debate... você na Band... boa noite... ((aplausos))

((vinheta de encerramento do debate))

No que se refere às falácias apresentadas nessa amostra do corpus, busca-se verificar sua adequação aos estágios de ocorrência, conforme proposto pela Pragmadialética. Nesse sentido, observamos que a pergunta de Kassab à candidata Marta Suplicy apresenta um dado que se destaca: o candidato só formula, efetivamente, sua pergunta após falar de si próprio, 
destacando seus feitos positivos: "na nossa gestão... demos sequência a um projeto (...) que nunca tinha acontecido na cidade antes... TRIplicamos o volume pavimentado na cidade de São Paulo... eh... QUAdruplicamos o que foi recapeado... cuidamos melhor da cidade e... Evidentemente isso trouxe uma SÉrie de benefícios (...)" . Tal pergunta, apresentada pelo interlocutor, vem para salientar os atos negativos da candidata, procurando sugerir, por meio de uma afirmação implícita, que a gestão de Marta Suplicy foi ineficiente "POR que na sua gestão as áreas pavimentadas foram TÃO insignificantes... por que foram TÃO pouco pavimentadas na sua gestão?" (linhas 40 a 47 - página 227)

A falácia que ocorre pode ser classificada como "falácia das perguntas múltiplas" e consiste em uma violação à regra número 6: regra do ponto de partida, a qual apregoa que os participantes não podem apresentar falsamente ou negar que uma premissa represente um ponto de partida aceito.

Observa-se, ainda, no segmento seguinte, que o candidato Kassab (L3), em seu turno e ao formular seu enunciado, comete uma falácia da falsa analogia no momento em que realiza uma comparação com base em semelhanças não passíveis de comprovação e baseadas em traços similares: "L3: para que o telespectador possa compreender o que a candidata fala... em uma maneira mais simples... ela diz o seguinte... você que paga aluguel... você que tem despesas na escola de seu filho... não precisa ter conta... ter dinheiro em conta não porque... use o cheque especial... é isso o que ela quer dizer..”, conforme segmento localizado à página 239, linhas 38 a 41 . Tal procedimento parece ser detectado por sua interlocutora e antagonista Marta Suplicy (L2) que, ao realizar seu turno, deixa claro que aquele não era o tópico em discussão: “... nós não estamos falando disso... nós estamos falando de uma família que... muitas vezes não vai comprar uma comida ou não vai 
comprar um tênis para deixar o dinheiro economizado... isso não existe... né?... a gente cuida primeiro das necessidades... e foi o que você não fez... né?...”, conforme as linhas 9 a 13, da página 240:

L3: para que o telespectador possa compreender o que a candidata fala... em uma maneira mais simples... ela diz o seguinte... você que paga aluguel... você que tem despesas na escola de seu filho... não precisa ter conta... ter dinheiro em conta não porque... use o cheque especial... é isso o que ela quer dizer... a cidade de São Paulo... uma cidade com ONze milhões de habitantes... uma prefeitura que tem responsabilidades... que tem compromissos... precisa ter recursos em caixa para não quebrar... como aliás estava quebrada no final da gestão Marta...[.....]

L2: olha... desculpa Fernando... mas ele falou uma coisa que eu quero/... que eu quero comentar antes... ele disse que o:.... a família paga suas contas e tal... e deixa o dinheiro guardado... nós não estamos falando disso... nós estamos falando de uma família que... muitas vezes não vai comprar uma comida ou não vai comprar um tênis para deixar o dinheiro economizado... isso não existe... né?... a gente cuida primeiro das necessidades... e foi o que você não fez... né?... você deixou dinheiro no banco... faltando creche... faltando corredor de ônibus... faltando TANta coisa na cidade.

(linha 38 - página 239 à linha 14 - página 240)

Tal falácia tem sua ocorrência no terceiro estágio da discussão crítica, a argumentação, conforme a exposição teórica da Pragmadialética e, como tal, consiste em uma violação à regra número 7: a Regra da validade, na qual é apregoado que a razoabilidade que se apresenta como formalmente conclusiva na argumentação não deve ser invalidada em um sentido lógico, o que pode ser depreendido na análise em questão.

Convém ressaltar que, nessa amostra, encontramos a ocorrência de uma falácia ad hominem cometida por Marta Suplicy, ao declarar que Gilberto Kassab havia mentido (ato de fala assertivo), por meio do seguinte segmento : "L2: mentira de novo... você falou uma mentira do Vai e Volta... são... eu deixei... CENto e quatorze MIL... e você hoje fornece para cento/... pra setenta e um MIL... não adianta mentir... isso está publicado... pode oLHAR... ao mesmo tempo... e não é... agora ainda vem com essa 
história porque construiu muita escola perto... olha... é... é... eu fico PASma com isso". Tal ocorrência propicia o direito de resposta ao participante nela citado, e a organização do debate classificou tal fala como uma violação a regras préacordadas $^{66}$, conforme o segmento seguinte localizado à pagina 241 , linhas 7 a $44:$

L2: mentira de novo... você falou uma mentira do Vai e Volta... são... eu deixei... CENto e quatorze MIL... e você hoje fornece para cento/... pra setenta e um MIL... não adianta mentir... isso está publicado... pode oLHAR... ao mesmo tempo... e não é... agora ainda vem com essa história porque construiu muita escola perto... olha... é... é... eu fico PASma com isso... ao mesmo tempo você não ofereCEu magisTÉrio pra... pro pessoal de CREche... você não ofereCEu curso universitÁrio para o pessoal da... da... que dá aula... que eu fiz na nossa gestão... formamos na universidade mais de três mil e quinhentos professores... então nós vamos investir PRA VAler... SIM... na educação... porque... quando você cria um Ceu já é com esse conceito... e agora você acabou de dar uma escorregada... quando você disse que eu tinha... não tinha que ter feito o Ceu... ué?... eu NÃO SÓ fiz os vinte e um Ceus... COmo... comecei a tirar as escolas de LAta que VOcê CRIou... e que eu comecei a tirar e deixei TOdas contratadas para você... e essa é a verdade...

L1: senhor Kassab... o senhor está pedindo réplica?...

L3: não... ela pela terceira vez... ela disse que eu menti...

L1: não... não...

L2:

não... não... não...

[

L1:

um instantinho por gentileza... se o senhor quer direito de resposta... tem que consULtar...

[

L3:

eu sei disso...

$\overline{66}$ Tal preocupação com regras anteriormente aceitas pelos participantes, e posteriormente violadas, parece-nos apresentar certa semelhança com o conceito de discussão crítica, 
L1:

a nossa equipe de juristas... então ah... em seguida... no final do bloco... ou no... no começo do PRóximo bloco... nós teremos a resposta... da nossa equipe de juristas... se o senhor tem ou não direito...

L3: $\quad$ perfeito...

Também classificada como falácia ad hominem, da variante tu quoque, a qual, de acordo como o quadro ilustrativo, procura apresentar inconsistências nos atos de seu oponente, o turno (ato de fala diretivo) de Marta Suplicy procura indicar que o candidato Gilberto Kassab tem atitudes duvidosas, enquanto prefeito da cidade de São Paulo, que são omitidas ou dissimuladas pela propaganda eleitoral veiculada por ele, conforme atestam os segmentos localizados à página 229, linhas 8 a 33, em que Marta estabelece uma dicotomia entre o Kassab real e aquele criado pela propaganda e pelo marketing: “ a pergunta que eu faço é... em que KASSAB a população deve acreditar?... No Kassab reAL que veTOU... em dois mil e seis aquele proJEto ou o Kassab da propaganda que agora diz que vai fazer Ceu profissionalizante... nos Ceus... haja visto que são dois Kassabs... um preFElto que está ali com a caNEta e o outro é o Kassab que você vê na propaganda... NÃO corresPONde... um veta e o outro na campanha diz que vai fazer...". No momento em que se expressa, a candidata, explicita que o Kassab da propaganda não corresponderia à realidade. Há um Kassab real versus Kassab da propaganda; Kassab prefeito versus Kassab da propaganda; um que veta versus aquele que diz que vai fazer. Observa-se, inclusive, a insistência, a repetição da ocorrência que é também estratégica. 
L2: a pergunta que eu faço é... em que KASSAB a população deve acreditar?... No Kassab reAL que veTOU... em dois mil e seis aquele proJEto ou o Kassab da propaganda que agora diz que vai fazer Ceu profissionalizante... nos Ceus... haja visto que são dois Kassabs... um preFElto que está ali com a caNEta e o outro é o Kassab que você vê na propaganda... NÃO corresPONde... um veta e o outro na campanha diz que vai fazer...

[......] L3: [...]e também estamos apresentando... através da parceRIA com o Governo do Estado... uma alternaTIva viÁvel... uma alternativa eficiente... de trazer os cursos técnicos para a cidade de São Paulo...

L2: in Kassab... acho que agora você confirmou o que eu estava faLANdo... porque você diz que está fazendo em parceria com o Estado... mas na tua propaganda você falou outra coisa... na tua propaganda você falou que vai fazer curso profissionalizante no Ceu... mas eu gostaria de ler aqui... é o veto que você deu ao projeto... né?... diz assim... "seja por ferir a autonomia das escolas...

Ainda, encontramos mais uma falácia do tipo ad hominem (por meio de um ato de fala assertivo) em que Marta Suplicy acusa Kassab de misturar determinadas as informações e omitir outras: “... mas aí você inverte TANto... embaralha TANto... que a gente não sabe nem por ONde começa a desmentir (...) VOcê não esTÁ contaNdo...(...) esse detalhe você esqueceu... né?..." Por meio do termo "desmentir" pode-se dizer que a candidata pretende levar à conclusão de que Kassab mentiu, conforme o seguinte segmento localizado às linhas 38 a 49 da página 228:

L2: CREdo... mas aí você inverte TANto... embaralha TANto... que a gente não sabe nem por ONde começa a desmentir... KAssab... eu estou PASma com o que você está falando... essa questão do asfalto comunitário... era um JElto de uma prefeiTUra FALIda... que VOcê deiXOU... conti/... consegui asfaltar essa cidade... a prefeitura pagava uma porCENTAgem... e a pessoa que morava naquela RUA... também pagava uma porcentagem... o que foi FEio... VOcê não esTÁ conTANdo... é que vocês uSARAM esse contrato que eu TInha... e... e... esse contrato pagava para as construTOras... MUlto mais... porque tinha muita inadimPLÊNcia... e aí vocês usaram o mesmo contrato... e continuaram pagando para as em/... para as construTOras... 0 mesmo preço do asfalto... esse detalhe você esqueceu... né?...

Destacamos que, conforme dissemos anteriormente, tais falácias, de acordo com a teoria que ampara nosso trabalho, teriam sua ocorrência no 
estágio primeiro da discussão crítica; entretanto, em nosso corpus encontramos também no terceiro estágio, destacando a especificidade do gênero debate político eleitoral e as características referentes ao contexto de sua ocorrência.

Outro tipo de falácia também encontrado na amostra que analisamos refere-se àquele que consiste em apresentar argumentação irrelevante para o tópico em discussão pelo interlocutor, nomeada Ignoratio elenchi e, como tal, torna-se uma violação à regra número 4: Regra da relevância. Tal ocorrência se dá no momento em que a candidata Marta Suplicy, ao responder a uma pergunta de Kassab sobre suas propostas em relação ao meio ambiente, utiliza a maior parte de seu tempo para tratar de outro assunto: a situação de São Paulo no momento em que assumiu a prefeitura. Isso se marca a partir da utilização do marcador "Olha" e, em seguida, ao indicar "primeiro eu quero .....": "L2: olha... primeiro eu quero comeÇAR... falando dessa história de cidade quebrada... eu peguei a cidade quebrada de FAto::... foi REALMENte a SUA gesTÃO com O PITTA....", e apenas cita, rapidamente, o tópico inquirido pelo seu oponente ao final de sua interlocução: "em RelaÇÃo à poLUIÇÃo... a coisa mais importante... o que MAIS POLUI... são os... os caRRoS na ciDAde... então nós temos que melhorar o transporte PÚBLIco... que foi o que eu FIZ... fazendo os corredores que você não fez nenhum... e ISSO que vai... que vai dar o grande passo... que as pessoas podem deixar o carro em casa e ir... eh:.... de ônibus...".

Tal fato parece ser detectado pelo seu interlocutor no momento em que ele destaca ao mediador a falta da resposta à pergunta feita por ele: "L1: olha Boris... é impressioNANTE... mas eu não vou te questionar não... mas ela não resPoNdeu sobre o verde e o meio ambiente... faLOU sobre a... necessidade da:: tirar os veículos da rua 
mas é transporte.." , conforme o segmento localizado às linhas 17 a 54 da página

234:

[....] eu queria... aqui perguntar pra... candidata Marta... QUAis são as suas propostas para o VERde e o meio ambiente?

L2: olha... primeiro eu quero comeÇAR... falando dessa história de cidade quebrada... eu peguei a cidade quebrada de FAto::... foi REALMENte a SUA gesTÃO com O PITTA... me deixou a cidade com uma dívida giganTESCA... ou você não TÁ lemBRADO... dos precaTÓRlos... dessa cidade... que foram vendidos Títulos para paGAR os precaTóRlos... que/... e que depois esses Títulos eram TOdos FRIos... e que deixou tudo... pra/... PRA MIM.... quando fui eleita... PRA paGAR... voCE não esTÁ lembrado do Pas que voCÊ ajudou a CRlar... você não está lembrado... do CAos também... que tinha no transPORte?... o qu/... no final da gestão PITTA... NÓS tiNHAmos oito MIL vans clandesTINAS... enTÃO eu quero dizer que o que eu entreguei para vocês... é in-fi-ni-ta-men-te melhor do que eu recebi... eu entreguei uma cidade organiZADA... deu um salto giganTESCO criANDO a... o plano diretor para a ciDAde... um zoNEAMENto... trinta e uma subprefeituras que na MInha gesTÃO... quando eu cheGUEI... NÃO tiNHA UM comPUTADOR... entende?... vocês receBEram a cidade organiZAda... o Pas já tinha ido há QUAtro anos... já tinha o recurso do Sus... enTÃO... OLHA... tinha vinte e um Ceus criados... voCÊS... quando DIZ... que ah... é o orçamento... porque fiscalizamos... isso realmente pode melhorar um pouco porque eu deixei esse processo em andamento... mas a... a prefeitura melhorou... não foi por causa disso... foi por CAUSA do goVERno LU-LA... da maco/... da macro-economia desse PAIS... que fez TODAS AS PREFEITURAS DESSE PAÍS... crescerem... enTÂO é BOM saber disso... se você tem dez Bllhões a MAIS por ano... NÃO é da GRANde CAPACldade de adminisTRAção... é da grande capacidade do Lula de fazer esse país crescer... ((vaias e aplausos))... em relação ao meio... [...] em RelaÇÃO à poLUIÇÃO... a coisa mais importante... o que MAIS POLUI... são os... os caRROS na ciDAde... então nós temos que melhorar o transporte PÚBLIco... que foi o que eu FIZ... fazendo os corredores que você não fez nenhum... e ISSO que vai... que vai dar o grande passo... que as pessoas podem deixar o carro em casa e ir... eh::... de ônibus...

L1: olha Boris... é impressioNANTE... mas eu não vou te questionar não... mas ela não resPONdeu sobre o verde e o meio ambiente... faLOU sobre a... necessidade da:: tirar os veículos da rua mas é transporte...

No que se refere à amostra que consta do debate político eleitoral

realizado em 19 de outubro de 2008, com duração de cento e nove minutos e quarenta e nove segundos, veiculado pela Rede Record de Rádio e Televisão e com a participação dos seguintes interlocutores: L1: Celso Freitas, L2: Gilberto Kassab, L3: Marta Suplicy, L4: Adriana Araújo e L5: Cristina Lemos, observa-se que os estágios da discussão crítica estão assim configurados: 
O primeiro estágio - confrontação- tem sua realização a partir do momento que o mediador Celso Freitas apresenta as questões que serão discutidas pelos participantes: "o debate deciSlvo entre os candidatos escolhidos para disputar o segundo turno da eleição... o debate pode ser acompanhado pelo site da Record... no endereço www.rederecord.com.br... estão aqui... para discutir iDEias e planos de governo..", conforme o segmento a seguir, localizado à página 255, linhas 16 a 39:

L1: boa noite... o eleitor da cidade de São Paulo acompanha ao Vlvo... a partir de agora... pela REde Record... com cobertura da Record News... o debate deciSlvo entre os candidatos escolhidos para disputar o segundo turno da eleição... o debate pode ser acompanhado pelo site da Record... no endereço www.rederecord.com.br... estão aqui... para discutir iDEias e planos de governo... o candidato Gilberto Kassab... do Dem... representante da coligação São Paulo no Rumo Certo... boa noite candidato... Gilberto Kassab...[....]

L1: obrigado candidato... a candidata do Pt... representando a coligação Uma NOva Atitude Para São Paulo... Marta Suplicy... também terá UM miNUto para se apresentar... boa noite candidata...

Já o segundo estágio - a abertura- ocorre no turno de L1, no momento em que ele apresenta tanto o acordo das partes para a realização do debate quanto às determinadas regras que devem ser obedecidas, de acordo com o segmento localizado à página 256, linhas 6 a 16:

L1: antes de dar início ao debate... eu quero lembrar que o candidato que se sentir vítima de caLÚnia... injúria ou difamação... poderá pedir direito de resposta... advogados da Rede Record... vão analisar se HÁ fundamento no pedido... em caso positivo... o candidato ofendido terá TRINta segundos... para se defender... a resposta será dada até o final do bloco... no qual foi feito o pedido de defesa... vamos agora às regras deste primeiro bloco... cada uma das jornalistas alternadamente escolherá um candidato... a quem fará a sua pergunta e pedirá que seu concorrente comente a resposta... o candidato que responder terá direito à réplica... os tempos são os seguintes... pergunta da jornalista... trinta segundos... resposta... dois minutos... comentário... um minuto e quinze segundos... réplica... um minuto... as jornalistas farão duas perguntas cada uma...[...] 
O terceiro estágio - a argumentação- inicia quando os participantes, efetivamente, dirigem suas interlocuções um a outro, fazendo uso de argumentos e contra-argumentos para fundamentar a opinião, o que tem início no segmento seguinte, localizado à página 257, linhas 19 a 23:

L2: gostaria que a... ex-prefeita disesse/... dissesse isso... para os professores... para os médicos... para os servidores municipais... que SAbem como foram tratados na sua gestão... sabem como as suas reivindicações eram atendidas... sabem o PAdrão salarial que tinha/... que tinham no início do governo...

E por fim, o quarto estágio - a conclusão se dá à página 280, linha 50, conforme o segmento a seguir, em que o mediador apoiado em sua autoridade performa o ato de fala do tipo declarativo de uso " chegamos assim ao fim desse debate decisivo.." e termina o evento discursivo, possivelmente em decorrência de uma limitação do tempo.

L1: obrigado candidato... chegamos assim ao fim desse debate decisivo... a Rede Record espera ter contribuído para que você eleitor... tenha tido a oportunidade de conhecer melhor... os dois candidatos... que pretendem governar a cidade de São Paulo... a transmissão continua ao vivo na Record News... canal quarenta e dois Uhf... com entrevistas... e a repercussão do debate... e a reportagem comPLEta em nossos telejornais... eleições dois mil oito... o VO-to na Record...

(linha 55-página 280 a linha 8-página 281)

Em relação às falácias que tiveram lugar nessa amostra do corpus, podemos observar que a candidata Marta Suplicy procura utilizar-se do argumento ad hominem (por meio de um ato de fala assertivo) para atingir o seu oponente e acaba por cometer uma falácia, uma vez que a expressão de suas impressões pessoais sobre Gilberto Kassab colocam em dúvida seu caráter e integridade: “... você tirou foi benefícios das pessoas... e eu vou por de novo... 
direito de recarregar na caTRACA... porque isso que você fez... é uma maIDADE com as pessoas mais pobres... que é o que você gosta de fazer... você maquia as coisas...", conforme segmento localizado às linhas 18 a 26, página 269:

L3: que interessante Kassab... TUdo o que você ciTOU... são as coisas que eu fiz para essa ciDAde... o uniforme... quem criou fui eu... você entrega tamanhos diferentes... no verão... os do inverno... quando você fala da caTRAca... eu fico pasma... porque quem fez o bilhete úNIco... que pôs a catraca... e permitiu à essa população ter um transporte decente... fui eu... você tirou foi beneFícios das pessoas... e eu vou por de novo... direito de recarregar na caTRACA... porque isso que você fez... é uma maIDADE com as pessoas mais pobres... que é o que você gosta de fazer... você maquia as coisas... quando a gente vai ver por exemplo essa situação da catraca... você vê que você fala da fraUde [...]

Ainda, nessa amostra, acreditamos ser importante destacar que os participantes comentam, por meio da pergunta acerca de uma propaganda, veiculada na campanha eleitoral e criada pelo partido da candidata Marta Suplicy, que se utilizou de uma falácia ad hominem contra Gilberto Kassab: "a pergunta vai para MARta Suplicy... candidata... a sua campanha começou o horário político do segundo turno... perguntando se o candidato Gilberto Kassab é caSAdo... se tem Fllhos... a propaganda foi considerada precon-CEltuosa... e saiu do ar depois de dois dias de exibição... a senhora se arrepende de ter usado essa propaganda?..". Tal propaganda foi entendida pelos telespectadores/auditório como um questionamento sobre a orientação sexual de Kassab (fato que se encontra no campo do implícito e do indireto). Essa a afirmação em forma de pergunta foi compreendida como um ataque pessoal pelos órgãos competentes e pela opinião pública, conforme é possível $\begin{array}{llll}\text { depreender } & \text { da } & \text { fala } & \text { Marta }\end{array}$ Suplicy (L3) e Gilberto Kassab (L2), nos seguintes segmentos: "L3: o QUE fizeRAM depois com as perguntas... Aí foi outra coisa... falou-se... criou-se o grande ceLEUma dessa campanha... em relação... àquelas perguntas." [...] L2: quanto ao MAquiavelismo... e as insiNUAções mentiROsas e MALdosas da campanha da minha adversária... a jusTlça se pronunciou... e CONdenou... com MUlto riGOR... a campanha da 
Marta... ela perdeu mais de quatroCENtos minutos de tempo na televisão... portanto não tenho nada a falar sobre isso... a minha vida... sou solteiro... sou feliz... sou engenheiro... sou economista.." localizados da página 257, linha 35 à página 259, linha 23:

L5: a pergunta vai para MARta Suplicy... candidata... a sua campanha começou o horário político do segundo turno... perguntando se o candidato Gilberto Kassab é caSAdo... se tem Fllhos... a propaganda foi considerada precon-CEltuosa... e saiu do ar depois de dois dias de exibição... a senhora se arrepende de ter usado essa propaganda?...

L3: olha... eu fiquei muito espantada com o que aconteceu com essa propaganda... o... a ressonância dessa propaganda... porque... ela foi feita... junta com diversas perguntas... e eram perguntas que foram TEStadas pelo marqueteiro... em GRUpos que se testam para por no ar... e não causaram NAda... ninguém viu aquelas perguntas como malicia... agora... o QUE fizeRAM depois com as perguntas... Aí foi outra coisa... falou-se... criou-se - grande ceLEUma dessa campanha... em relação... àquelas perguntas... as perguntas são perguntas... que dizem respeito... à trajeTÓria DO CANdidato... eu acho que as pessoas tem direito a saber... TOdas aquelas perguntas aLI... e você pode dizer... mas o que é que influencia saber que ele é casado... o que influencia saber se ele era rico... ou ficou rico na política... o que é que influencia saber isso ou saber aquilo... eu acho que são perguntas que de/... que dizem respeito a uma candidatura... então eu acredito... que criou-se TOda essa ceLEUma... não pela perGUNta eXAta... mas porque a perGUNta... e as outras perGUNtas... falavam que a população não conhece Gilberto Kassab... isso que foi... porque... aTÉ enTÃo... ninguém sabia... que ele era... braço direito do Pitta... as pessoas não sabiam que ele é do PfL... um partido em extinção no BRAsil... né?... perdeu todas as eleições municipais... então era... foi absolutamente imporTANte... para as pessoas conheceREM... quem é o candidato... em relação ao RESto... gente... eu digo... eu sou... talvez a pessoa nesse Brasil... que mais defendeu direitos humanos... minorias... e tudo o que estão colocando em cima de mim... olha... principalmente... os grupos gays... homossexuais... todos... eu agradeço o apoio... porque sabem que eu NUNca seria parCElra... em alguma coisa que pudesse geRAR... uma confusão e tudo isso... isso aconteCEU... eu rePITO... porque invés de se discutir... poLítica... e $O$ parTIdo DO candidato... ficaram num detalhe... né?... que perverteRAM... para poder discutir OUtra colSA... e não a ficha dele...

\section{L1: comentário do candidato Gilberto Kassab...}

L2: quanto ao MAquiavelismo... e as insiNUAções mentiROsas e MALdosas da campanha da minha adversária... a jusTlça se pronunciou... e CONdenou... com MUlto rigOR... a campanha da Marta... ela perdeu mais de quatroCENtos minutos de tempo na televisão... portanto não tenho nada a falar sobre isso... a minha vida... sou solteiro... sou feliz... sou engenheiro... sou economista... e posso dizer à prefeita... e sua campanha... que o cidadão... ele está interessado em discutir o caRÁter das pessoas... ele está interessado em discutir a capacidade administrativa... e o meu governo é MUlto bem avaliado... sessenta e um por cento dos paulistanos entendem que ele é ótimo ou bom... [...] 
Apesar de não ser possível observar o evento discursivo em que a falácia ocorre, de fato, em nosso corpus, e, em consequência, sua análise não pode ser realizada de modo detalhado; cabe aqui ressaltarmos tal fato como mais um exemplo da recorrência de um padrão de comportamento linguístico e discursivo dos participantes do evento que se constitui no gênero sob análise: 0 ataque pessoal em detrimento da discussão dos projetos e planos de administração pública.

Ainda, na amostra do corpus observada, temos a ocorrência de uma falácia das perguntas múltiplas realizada pelo candidato Gillberto Kassab. Isso se dá pelo fato de apresentar uma afirmação implícita na pergunta (ato de fala diretivo) direcionada a Marta Suplicy: " eu pergunto:: a senhora... a você... Marta... porQUE... a cidade estava falida?... o que faLHOU no seu governo?...". Uma vez que Kassab formula tal pergunta sobre o que havia falhado na administração de Marta Suplicy, a conclusão que se infere é que, de fato, houve falhas, conforme segmento localizado à página 278, linhas 31 a 35 :

L2: candidata Marta... o seu governo terminou com oiTENta e nove obras paradas... GREves dos educadores dos Ceus... TRINta mil buracos nas ruas da cidade de São Paulo... diversos outros programas que ficaram no papel... eu... e a cidade quebrada... a cidade falida... eu pergunto:. a senhora... a você... Marta... porQUE... a cidade estava falida?... o que faLHOU no seu governo?...

Essa falácia ocorre no estágio da argumentação, conforme previsto no quadro proposto pela Pragmadialética, e viola a regra número seis: Regra do ponto de partida: os participantes não podem apresentar falsamente ou negar que uma premissa represente um ponto de partida aceito. 
Para dar prosseguimento às nossas análises, passamos à amostra seguinte do corpus, a qual se refere ao evento discursivo ocorrido em 24 de outubro de 2008, com duração de cem minutos e quarenta e seis segundos, veiculado pela Rede Globo e que contou com a participação dos seguintes interlocutores: L1: Chico Pinheiro, L2: Gilberto Kassab, L3: Marta Suplicy, L4: Rodrigo, L5: César Menezes, L6: Alda Marcoantonio, L7: Verusca Donato e L8: Aldo Rebelo.

Em relação aos estágios da discussão crítica, observa-se que o primeiro estágio - confrontação - ocorre após o estágio da abertura; nesse caso, apesar de os participantes do debate assumirem seus papéis de oponentes, a questão em discussão ou o tema a ser discutido é explicitado após a exposição do mediador sobre as regras e a organização do debate (a abertura).

Desse modo, a confrontação tem lugar a partir do segundo segmento localizado da página 282, linha 55 à página 283, linha 12, em que os candidatos discutem acerca da situação financeira da prefeitura de São Paulo à época da administração de Marta Suplicy:

L2: Marta... o seu vice... Hélio Bicudo... disse em seu livro que:: você deixou a cidade falida... quebrada... disse que:: o SErra herdou de você uma cidade quebrada... bueiros sem limpeza... dívidas na saúde... na educação... a cidade... um verdadeiro caOS... eu queria que você... falasse um pouco... em relação à situação deixada na cidade... analisada pelo seu próprio vice... Hélio Bicudo...

L3: Kassab... é muito importante... quando você analisa essa situação... ver... como é que ela veio para mim... e o que eu fiz... como eu terminei... e eu falo com MUlto orgulho como eu terminei... como entreguei esta cidade... pra José Serra e para você... primeiro eu tive as contas aprovadas... pelo tribunal de can/... de contas... tive pela câmara...[...] 
A abertura ocorreu anteriormente ao segmento acima, pois o mediador do debate (Chico Pinheiro) apresenta as regras do debate, indicando que serão cinco blocos, como deverá ser cada bloco, o tempo de cada um, a questão das réplicas e tréplicas, o turno de perguntas dos participantes, o impedimento em relação a ofensas pessoais e calúnias, ao uso de panfletos e à manifestação da plateia, ou seja, a estruturação do evento e os papéis que cada um dos participantes desempenhará, conforme o turno localizado à página 282, linhas 28 a 54:

L1: [....] o posicionamento dos candidatos aqui no estúdio... FOI... decidido... por sorTElo... o debate terá CINco blocos... e agora nós vamos conhecer as REgras... o primeiro e o terceiro blocos são de temas livres... os candidatos trocam perguntas sobre os assuntos que quiSErem... no segundo e no quarto blocos... os temas são determinados por sorteio... os candidatos terão trinta segundos para a pergunta... dois minutos para a resposta... um minuto para a RÉplica... e um minuto para a TRÉplica... eles perguntam e respondem o mesmo número de vezes... o candidato sorteado para a abrir o primeiro bloco... abrirá necessariamente o terceiro... o outro candidato abrirá o segundo e o quarto blocos... no quinto bloco... haverá novo sorteio para indicar o candidato que iniciará as considerações finais... as regras assinadas por representantes dos candidatos não permitem ofensas pessoais e acusações que atinjam a honra e a dignidade dos adversários... se um candidato se sentir ofendido ou caluniAdo pelo oponente... poderá pedir o direito de resposta... que será analisado por mim... com ajuda da nossa equipe de produção... mas eu tenho certeza que o debate será em alto Nível... e nós não vamos precisar usar esse reCURso... os candidatos não poderão exibir para as câmeras... nenhum tipo de documento... panFLEto... ou texto... ainda que manuscrito... as regras também não permitem... que um candidato fale FOra de hora... eu peço a todos os candidatos que estão aqui... em nosso estúdio... que se mantenham em siLÊNcio durante todo o debate para não prejudicar os candidatos e nem aqueles que nos acompanham pela tv... esse silêncio só poderá ser quebrado aGOra... na entrada dos dois candidatos... eu convido... Gilberto Kassab e Marta Suplicy... ((aplausos))... muito bem... vamos então... começar o debate... eu vou sorTEAR... o nome do candidato que irá fazer a PRIMEIra pergunta... sobre o assunto que quiser... o tema é liVRE... o candidato... ou a candidata... vamos ver... o candidato é Gilberto KaSSAb... o senhor tem trinta segundos para fazer a pergunta...[....]

O terceiro estágio e mais profícuo da discussão crítica, a argumentação, tem seu início quando os oponentes (candidatos) apresentam suas opiniões e argumentos. Isso se dá quando há uma contra-argumentação por parte daquele que, naquele momento, assume o papel do protagonista. No segmento 
sob análise, observa-se que Marta Suplicy, ao afirmar que havia deixado a cidade em ordem, recebe uma contra-argumentação por parte de seu interlocutor, Gilberto Kassab, discordando da opinião e apresentando o argumento de que havia noventa e seis obras paradas e outras malfeitas. Kassab destaca, ainda, o fato de o vice-prefeito de Marta Suplicy, ao assumir a gestão em uma das viagens da prefeita, afirmar que havia compromissos financeiros não cumpridos, os quais causaram inúmeros problemas à prefeitura à época do ocorrido. Isso é observado no segmento localizado à página 283, linhas 29 a 39:

L3: [...] coMÉRcio... era essa cidade... com a MÁfia dos fisCAis... as pessoas não podem esquecer o que foi... eu me esforCEl... eu FIZ... eu entreGUEI a cidade em orDEM... CONtas em orDEM... tanto é que vocês tinham dinheiro...

L2: você entregou a cidade com noVENta e seis obras paradas... TÚneis... mal-feitos... que nas chuvas... eram vítimas de enCHENtes... Dívidas... que chegaram a dois Bllhões de reais... e... o seu vice... que... assumiu a prefeitura... enquanto... durante dez dias... você estava em Paris... e durante DEZ dias ele pôde observar a cidade... na página duZENtos e quinze do seu livro dizia... "ao assumir o cargo... logo deparei com problemas surgidos em consequência de compromissos financeiros que não estavam sendo cumpridos... REfiro-me...[...]

Quanto ao estágio da conclusão - o quarto estágio- observa-se sua realização quando o mediador, investido da autoridade para tal, declara encerrado o evento discursivo por meio de um ato de fala declarativo de uso: "L1: e aSSIm... enceRRAmos o ÚLtimo deBAte entre os candiDAtos para a prefeitura de São PAUlo... nas eleições de dois mil e oito... nós agradeCEmos a participaÇÃO..", em razão da limitação do tempo do programa televisivo, de acordo com o segmento localizado à pagina 305 , linhas 40 a 50:

L1: e aSSIm... enceRRAmos o ÚLtimo deBAte entre os candiDAtos para a prefeitura de São PAUlo... nas eleições de dois mil e oito... nós agradeCEmos a participaÇÃO... a presença da candidata Marta SuplicY... 
do candidato Giberto KaSSAb... aos candidatos aqui presentes... e principalmente a voCÊ... eleitor... que nos honrou com a sua audiência... nós vamos acompanhar os momentos de camPAnha... desses candidatos... e domingo... depois de amaNHÃ... vinte e seis de ouTUbro... você terá cobertura completa aqui na Tv Globo... de TOdo o proceSSO de votação e apuração... nessas eleições municipais de dois mil e oito... NÃO esqueçam... de exercer BEM... o seu direito de ser cidadão... e VOtem... tenham TOdos... uma BOA noite... e que tenham um bom voto... obrigado... ((aplausos))...

De acordo com nossa análise, a classificação dos quatro estágios da discussão crítica na amostra em questão é efetuada de modo claro, podendo configurar uma afirmação da aplicabilidade de tal aparato teórico. A seguir, passamos a observar a ocorrência de falácias enquanto violações a regras sintetizadas no Código de Conduta para os participantes da discussão crítica, no evento discursivo sob análise.

No segmento a seguir, localizado à página 293, linhas 16 a 23, observamos que a candidata Marta Suplicy comete uma falácia do tipo ad hominem ao acusar o seu oponente de utilizar dados e números falsos, por meio de um ato de fala assertivo: "L3: esses dados que o Kassab coloca... não são verdadeiros... não existe essa ampliação de fato....". Destaca-se que tal argumento teria validade e, portanto, valor argumentativo se a interlocutora apresentasse fatos ou dados que comprovassem tal acusação. Tal embasamento não é feito por Marta Suplicy e, desse modo, caracteriza-se uma falácia, cometida pela candidata, que viola a regra número 1: a Regra da liberdade: as partes não devem impedir-se de avançar no ponto de vista ou de questionar a opinião.

L3: esses dados que o Kassab coloca... não são verdadeiros... não existe essa ampliação de fato... agora que estão chamando concurso da guarda... e a ROnda Escolar NÃO existe... o programa Reluz... vocês ficaram discutindo... a venda da conta da... luz do Itaú... acabaram não podendo... não podendo ter aCEsso ao Reluz por Isso perderam cento e oitenta e cinco milhões... ninguém está mal informado aqui... e as câmeras de segurança... acho importante coloCAr... mas nós vamos fazer observaTÓrios de segurança... 
nas subprefeituras... por que?... com a secretaria de segurança... São Paulo... que é $[\ldots]$

(linhas 16- 23, página 293)

O participante do debate Gilberto Kassab comete uma falácia do tipo Ignoratio elenchi, por não direcionar sua argumentação ao foco em questão e apresentar inúmeros argumentos relacionados ao tópico da saúde, mas não ao aspecto citado pela sua oponente, o que caracteriza uma espécie de argumentação irrelevante: "L2: é fácil Marta... até porque o MESmo lbope... fez uma entrevista depois... com os usuÁrios dos NOvos serviços... e os usuÁrios dos NOvos serviços... mostraram que estão MUlto contentes com os novos serviços..." (linhas 15-19, página 299 ).

Tal fuga do questionamento parece ter sido detectada pela candidata Marta Suplicy, conforme pode-se depreender do seguinte segmento, às linhas 44 e 42, página 299: "L3: Kassab... você não respondeu... eu coloquei... que sessenta e nove por cento... através da pesquisa lbope... consideraram a saúde ruim e péssima...".

Esse tipo de violação é previsto pela Pragmadialética nesse estágio da discussão crítica e se classifica como uma violação a regra número 4: a Regra da relevância- a opinião não pode ser defendida por meio de nãoargumentação ou argumentação irrelevante.

O segmento seguinte, localizado à página 299, linhas 10 a 56, apresenta a contextualização de falácia Ignoratio elenchi que explicitamos:

L3: Kassab... o lbope... contratado pelo instituto Nossa... São Paulo... fez uma pesquisa que mostrou... que seSSENta e nove por cento das pessoas... consideram a saúde como RUim e PÉssima na cidade de São Paulo... e seTENta por cento estão MUlto insatisfeitas com a saúde... os seus dados são sempre sobre as Amas e dessa satisfação... eu gostaria de fal/... que você 
respondesse... sobre esta pesquisa MAis ampla... que é com TOdos os usuários as saúde... como é que você explica essa realidade?...

L2: é fácil Marta... até porque o MESmo lbope... fez uma entrevista depois... com os usuÁrios dos NOvos serviços... e os usuÁrios dos NOvos serviços... mostraram que estão MUlto contentes com os novos serviços... [........ e... a minha gestão é muito bem avaliada... seSSENta por cento dos paulistanos entendem que ela é ótima ou boa... e o serviço de saúde e de educação... melhoraram sim... melhoraram MUlto... TANto é... que esse mesmo lbope que você cita aqui... um instituto de muita credibilidade... assim como o Datafolha... mas voltando ao Ibope... nós TEmos que... TOdos os usuários do sistema... público de saúde... em especial... aquele voltado as Amas... um Mllhão de pessoas por mês... deram nota acima de NOve... do Mãe Paulistana... nota acima de NOve... dos DOis novos hospitais... nota acima de Olto... e hoje... eu quero dizer a você... telespectador... que a exprefeita fez um desafio querendo saber... quem conhece o programa Remédio em Casa... quem conhece uma pessoa que recebe o Remédio em Casa... São Paulo tem ONze milhões de habitantes... desses ONze milhões de habitantes... nós temos CENto e vinte mil pessoas... que recebem o remédio em casa... são os usuÁrios desse programa... são faMílias atendidas... e nós vamos continuar ampliANdo esse sistema... porque nós não TEmos preocupação de colocar o nome em placa... ou atender de uma maneira (macro) tudo... nós temos preocupação de fazer com qualidade... e melhorou MUlto o sistema público de saúde conosco...

L3: Kassab... você não respondeu... eu coloquei... que sessenta e nove por cento... através da pesquisa lbope... consideraram a saúde ruim e péssima... você está desrespeitando as pessoas que votaram... e seTENta por cento... colocaram como MUlto ruim... a... a avaliação... na demora dos exames... você está desrespeitando esse cidadão... você PINça algumas pesquisas referentes... à alGUNS programas... que se estão bons... nós VAmos continuar... mas nós VAmos fazer funcionar a saÚde... como sistema inteGRAdo... que é o jeito como a saúde tem que funcionar... que a pessoa que entre pela Ama... que é a porta de enTRAda... ela consiga fazer um exame numa poliCLínica... na região DEla... a pessoa que entre por uma Ubs... consiga fazer um exame na policlínica na região DEla... aquele exame de tomografia... que hoje demora... quanto tempo?... dez meses... que eu esCUto... e que faz setenta per/... por cento dos usuários... estarem insatisfeitos... então há uma MANIpulação de dados...

Destaca-se que, nesse mesmo segmento, Marta Suplicy acusa seu oponente de manipular dados de pesquisas, um fato que passa quase despercebido pelos interlocutores como falácia, mas pode ser assim classificado por consistir em uma acusação indireta à honestidade e veracidade dos números apresentados por Gilberto Kassab, caracterizando, por meio de um ato de fala assertivo, uma falácia do tipo ad hominem, conforme a seguinte fala da candidata: “.. então há uma MANIpulação de dados..”, de acordo com o 
segmento à página 299, linhas 55 e 56. Destaca-se que essa falácia ocorre no terceiro estágio da discussão crítica, diferentemente do previsto pela Pragmadialética.

L3: (....) ?... dez meses... que eu esCUto... e que faz setenta per/... por cento dos usuários... estarem insatisfeitos... então há uma MANIpulação de dados...[...]

Ainda na amostra sob análise, encontramos a ocorrência de duas modalidades de falácias: a primeira, cometida por Marta Suplicy, refere-se à falácia das múltiplas perguntas, uma violação à regra número 6: Regra do ponto de partida - os participantes não podem apresentar falsamente uma premissa como ponto de partida aceito ou negar que uma premissa represente um ponto de partida aceito - uma vez que ela expõe como fato consumado a sua opinião de que os títulos precatórios foram um problema da gestão de Kassab e insinua, de maneira implícita, que há uma espécie de desvio do dinheiro público: "Kassab... eu recebi a ciDAde de São PAUlo... com uma dívida giganTESca... feita por você... que era o secretário de planejamento... e na época... planejamento lidava com o orçamento... bom... a dívida pública de São Paulo... foi... na gestão de vocês... de CINco BI para VINte e UM BI... a situação ficou tão difícil... que vocês tiveram que negociar com o Governo Federal... Fernando Henrique... deixaram uma situação

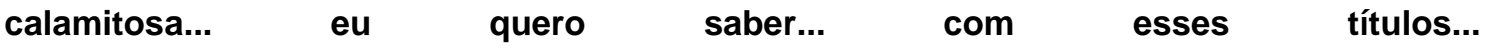
[ (...) que foram feitos... aonde foram os recursos?...”. (página 301- linhas 32 a 44)

Já a segunda ocorrência, referente a Gilberto Kassab, pode ser classificada como uma falácia do tipo ignoratio elenchi - violação à regra da relevância (número 4): a opinião não pode ser defendida por meio de nãoargumentação ou argumentação irrelevante: “L2: uma das coisas MAis importantes que tem na administração pública... é deixar o nome limpo na praça... você deixou a prefeitura 
de São Paulo QUEbrada... DOis bilhões de reais de dívidas... isso é de conhecimento público... TREze mil credores... eu posso afirmar que...”. (página 301 - linhas 46 a 49)

Pode-se dizer que tal situação decorre da apresentação de argumentos irrelevantes ao foco da discussão, os quais se constituem do ataque pessoal à antagonista (do tipo ad hominem, tu quoque): “[...] e eu tenho certeza absoluta... que o telespectador... que se recorda da época da ex-prefeita... quando era um governo voltado para a criação de TAxas e mais taxas... e eu pergunto aqui... a nossa ex-prefeita... candidata Marta... PRA que tanta TAxa?... bastava não jogar dinheiro fora com TÚnel... com obras que... estavam mal encaminhadas... com contratação de assessores de confiança... não precisava... era TAxa demais... até você pediu desculpas... mas... as pessoas tem dificuldade de entender o pedido de desculpas...", e de uma espécie de fuga da questão proposta por Marta Suplicy: "L2: o taxista... o alfaiate... a manicure... o cabeleireiro... a cabeleireira que está nos ouvindo sabe que nós... estamos isenTANdo o Iss dos profissionais autônomos... e também sabe... que eu nunca fui o responsável pelo orçamento... a não ser nesse momento... como prefeito da cidade de São Paulo... eu quero dizer... a todos vocês... que:.......]", conforme o segmento a seguir, localizado da página 301, linha 30, à página 302, linha 43:

L1: candidata... a senhora agora faz a sua pergunta... e o TEma do sorteio é... Dívida pública...

L3: dívida pública... eh:.... Kassab... eu recebi a ciDAde de São PAUlo... com uma dívida giganTESca... feita por você... que era o secretário de planejamento... e na época... planejamento lidava com o orçamento... bom... a dívida pública de São Paulo... foi... na gestão de vocês... de CINco BI para VINte e UM BI... a situação ficou tão difícil... que vocês tiveram que negociar com o Governo Federal... Fernando Henrique... deixaram uma situação calamitosa... eu quero saber... com esses títulos...

\section{[}

L1:

candidata...

L3:

aonde foram os recursos?...

que foram feitos... 
L1: $\quad$ candidata... acabou o seu tempo... por gentileza...

L2: uma das coisas MAis importantes que tem na administração pública... é deixar o nome limpo na praça... você deixou a prefeitura de São Paulo QUEbrada... DOis bilhões de reais de dívidas... isso é de conhecimento público... TREze mil credores... eu posso afirmar que... em relação à dívida pública... hoje... nós viRAmos a página na cidade de São Paulo... você diz que encontrou a cidade quebrada... nós encontramos... DUas vezes quebrada... nós colocamos a casa em ordem... nós investimos... passamos a investir em saúde... em educação... hoje... as contas estão rigorosamente em dia... nós inclusive... em relação a esse tema... nós... posso afirmar ao telespectador... que não criamos TAxas... não criamos impostos... ao contrário... estamos devolvendo treZENtos milhões de reais de Iptu... para as pessoas que usaram a nota fiscal eletrônica... portanto dívida pública é algo que não está na nossa gestão... é um tema que não existe... tivemos... MUltas dificuldades no começo... e hoje temos a felicidade de investir no metrô... de investi em corredores de ônibus... de investir na construção de parques... de fazer uma cidade melhor... uma cidade com atendimento público de saúde de mais qualidade... com ensino público de mais qualidade... e eu tenho certeza absoluta... que o telespectador... que se recorda da época da ex-prefeita... quando era um governo voltado para a criação de TAxas e mais taxas... e eu pergunto aqui... a nossa ex-prefeita... candidata Marta... PRA que tanta TAxa?... bastava não jogar dinheiro fora com TÚnel... com obras que... estavam mal encaminhadas... com contratação de assessores de confiança... não precisava... era TAxa demais... até você pediu desculpas... mas... as pessoas tem dificuldade de entender o pedido de desculpas...

L3: Kassab... não adianta você se furtar a responsabilidade da dívida que vocês deixaram para a cidade... e como vocês queBRAram a cidade... as próximas gerações vão ter que pagar TREze por cento do orçamento dessa cidade para dar conta da dívida que vocês deixaram... eu sei porque eu recebi a cidade acaBAda... não era só saúde... era a educação e o transporte... então por MAis que você fale... quem tem memória... lembra dos escândalos dos precaTórios... que foram emitidos Títulos... para pagar precatórios... esses títulos foram emitidos... e o dinheiro de-as-pa-re-ceu... os precaTÓrios é que geraram... toda essa dívida da cidade... isso está lá... Cpi dos Precatórios... a responsabilidade correndo na justiça... e quanto ao dinheiro que vocês vão isentar do Iptu... é bom que isente mesmo... vocês aumentaram em duzentos mil o número de pessoas que estão pagando Iptu nessa ciDAde... e virou Iptu mais CAro... além do... do Iss... que você aumentou... aliás... você fez novas... posso chamar de uma taxinha... de dois por cento... para TAxista... músico e alfaiate...

L2: o taxista... o alfaiate... a manicure... o cabeleireiro... a cabeleireira que está nos ouvindo sabe que nós... estamos isenTANdo o Iss dos profissionais autônomos... e também sabe... que eu nunca fui o responsável pelo orçamento... a não ser nesse momento... como prefeito da cidade de São Paulo... eu quero dizer... a todos vocês... que:.... os treze por cento da dívida que pagamos... todos os meses... ele tem sido pago rigorosamente em dia... nós hoje... temos a cidade de São Paulo com a saúde financeira... temos condição de investir... temos... enfim... uma cidade muito bem organizada... uma administração muito bem organizada... e eu lamento aqui... dizer para a ex-prefeita que sempre é recorrente... ela investiu mal... ela não acabou com as salas de lata... com as escolas de lata... vem sempre com a história de Pitta... mas não explica porque ela não se afastou do pessoal do MENsalão... porque eu me afastei do Pitta... 
L3: olha... você sabe muito bem...

As análises que efetuamos visando a aplicabilidade do aparato teórico proposto pela Pragmadialética em um gênero discursivo polêmico e de constituição particular como é o debate político eleitoral, em especial, na ocorrência de falácias, de acordo com os preceitos da teoria que embasa nossa pesquisa, permitem as reflexões que apresentamos a seguir. 
CONCLUSÃO 
Conforme tínhamos por hipótese, a caracterização do debate político eleitoral como um evento polêmico em que as opiniões não se apresentam como o alicerce, fundamento ou a tese principal do discurso dos interlocutores foi confirmada no corpus que se apresentou, pois os interlocutores, em muitas ocasiões, relegaram as opiniões a um segundo plano e cometeram violações que não seguiam os preceitos de determinadas regras do código de conduta proposto pela Pragmadialética, bem como, eles parecem se utilizar das falácias enquanto estratégias que procuram modificar o tópico em discussão, possibilitando diversos resultados e efeitos. Ainda, verificamos um grande número de ataques pessoais que não se apoiava em dados comprobatórios das afirmações apresentadas, prática de argumentação que pode trazer consequências ou efeitos diferentes dos previstos pelo interlocutor, conforme a análise parece delinear.

As análises efetuadas possibilitam afirmar que os participantes do debate político eleitoral procuram caracterizar-se como indivíduos aguerridos e combatentes, utilizando um grande número de argumentos para embasar suas opiniões. Tal utilização de opiniões e estratégias que podem se apoiar na polêmica leva-os, por vezes, a cometer falácias que podem depor contra suas imagens.

A aplicação da metodologia idealizada pela Pragmadialética, em um corpus dotado de grande carga polêmica, como se configura o debate político eleitoral, permite observar as características desse gênero discursivo, as quais pressupõem a não solução da discordância por meio da argumentação. $\quad 0$ desacordo pôde ser observado, em nosso corpus, pelas performações de atos 
de fala, que se constituem em argumentos, dos participantes do evento discursivo.

Convém destacarmos que a Pragmadialética tem raiz em uma cultura que parece estar mais preocupada com a resolução de uma discussão polêmica por meio de um procedimento amparado pela razoabilidade de seus participantes; em nosso contexto, com as características culturais que se ligam ao domínio pertencente ao embate acalorado, é necessária uma observação cuidadosa dos dados referentes a tal particularidade ao conduzirmos determinada pesquisa. Destaca-se que a adequação ao sistema cultural é referendado pelas orientações teóricas expostas pela Pragmadialética.

No que se refere ao objetivo proposto em nosso trabalho acerca da identificação do gênero analisado, podemos concluir que ele possui determinada estabilidade que possibilita caracterizar sua constituição. Esse fato torna-se possível em nossa análise, devido à sua estrutura composicional relacionar-se ao conceito de discussão crítica, composto pelos quatro estágios (confrontação, abertura, argumentação e conclusão), ordem que se mantém e torna o gênero estável e reconhecível pelos sujeitos.

Ainda, quanto ao gênero sob análise, concluímos, acrescentando o que Dascal $(1999,2005)$ entende por disputa, por inserir-se com adequação ao conceito que buscamos para o debate político eleitoral: consiste na exposição da verdade individual, não procura resolver adequadamente uma questão, ou levar a uma decisão sobre ela, os argumentos e estratégias são amparados pela Retórica, o processo de argumentar prescinde da razoabilidade, caracterizando-se por ser irracional, os temas debatidos versam sobre atitudes 
e não sobre temas, além de não ter o propósito de produzir mudanças na opinião daqueles que participam do evento discursivo.

Nossa ressalva refere-se ao último item listado como característica da tipologia proposta por Dascal (op. cit.), uma vez que os participantes da manifestação polêmica não procuram modificar a opinião um do outro, mas pretendem influenciar, por meio de estratégias persuasivas, o ponto de vista do auditório, composto por aqueles que possuem o poder do voto.

Podemos dizer que a especificidade de nosso corpus - o gênero debate político eleitoral, conforme tratamos no segundo capítulo - pode ser propícia à ocorrência de um maior número de falácias. Esse fator pode estar relacionado ao contexto de sua realização, como as influências decorrentes da cultura, das esferas discursivas e das relações entre os interlocutores.

Destacamos que nossas análises permitiram observar que o debate político eleitoral constitui-se em um campo fértil para que se observe a argumentação e a ocorrência do uso estratégico das falácias que podem não ser detectadas pelos interlocutores e, principalmente, pelo auditório.

Ainda em relação aos objetivos de nosso trabalho, podemos dizer que, ao analisarmos as regularidades linguístico-discursivas presentes no debate político eleitoral, por meio da aplicação dos conceitos da Pragmadialética de modelo idealizado de discussão crítica e de falácias como violações ao código de conduta para os participantes de uma discussão crítica, foi possível observar que esses correspondem a instrumentos adequados para a realização de estudos empíricos que examinem a Argumentação em diferentes culturas. 
No corpus analisado (debates políticos eleitorais, realizados por ocasião da eleição à Prefeitura de São Paulo, em 2008), pudemos detectar a ocorrência da estruturação do debate político eleitoral em comparação ao modelo idealizado de discussão crítica e a consequente conceituação de falácia como uma violação às regras da Pragmadialética, especificamente, no terceiro estágio desse modelo: a argumentação.

Ressaltamos que a aplicação do conceito de modelo idealizado de discussão crítica, em quatro estágios, mostrou-se bastante adequada às análises, nas quais foi possível observar a realização das quatro partes, mesmo que de maneira não linear e de modo implícito. A aplicação desse conceito abstrato e idealizado possibilitou a observação detalhada dos componentes linguísticos e discursivos que configuram o gênero selecionado.

Consideramos necessário, entretanto, destacar que o quarto estágio da discussão crítica - a conclusão - não ocorre do modo estabelecido pela teoria, mas sim, invariavelmente no corpus analisado, devido a uma limitação do tempo do debate político eleitoral. Tal circunstância externa, decorrente da esfera de atuação humana em que se situa o gênero discursivo, parece contrariar a definição das condições de fechamento ou resolução propostas pela Pragmadialética: uma discussão crítica só estaria de fato resolvida se houvesse uma modificação na opinião de um dos participantes do evento discursivo, o que não foi verificado em nossa análise.

Ainda em relação à metodologia proposta pela teoria que ampara nosso trabalho - a ocorrência de falácias enquanto uma violação a determinadas regras sintetizadas no Código de conduta para os participantes de uma 
discussão crítica, em estágios específicos desse modelo idealizado - ao analisarmos o corpus selecionado, pudemos apreender que há grande similaridade na ocorrência de falácias em determinados estágios da discussão crítica no debate político eleitoral e no que foi exposto pelas pesquisas empíricas realizadas pelos estudiosos da Pragmadialética, conforme o quadro à página 138 do nosso trabalho. Entretanto, pudemos observar certa divergência no que se refere à localização da ocorrência de um tipo determinado de falácia, a ad hominem, em um estágio diferente daquele proposto pela literatura.

Entendemos que a elaboração de um quadro ilustrativo possa explicitar melhor o que afirmamos. Nele, citamos as falácias localizadas e o estágio correspondente em nosso corpus em comparação ao exposto pela Pragmadialética, conforme apresentamos a seguir:

\begin{tabular}{|l|l|l|}
\hline FALÁCIA & $\begin{array}{l}\text { Estágio de ocorrência no } \\
\text { modelo da } \\
\text { Pragmadialética }\end{array}$ & $\begin{array}{l}\text { Estágio de ocorrência } \\
\text { em nosso corpus }\end{array}$ \\
\hline Ad populum & Terceiro estágio & Terceiro estágio \\
\hline Ignoratio elenchi. & Terceiro estágio & Terceiro estágio \\
\hline Ad hominem & Primeiro estágio & Terceiro estágio \\
\hline Falsa analogia & Terceiro estágio & Terceiro estágio \\
\hline Ad hominem - tu quoque & Primeiro estágio & Terceiro estágio \\
\hline $\begin{array}{l}\text { Falácia das perguntas } \\
\text { múltiplas }\end{array}$ & Terceiro estágio & Terceiro estágio \\
\hline
\end{tabular}

Quadro 7 - Resultados da análise das falácias. 
Ressaltamos, desse modo, a ocorrência da falácia do tipo ad hominem em um estágio diferente daquele citado pelas obras por nós referenciadas. Ainda, nossa constatação do grande número de ocorrências desse tipo de falácia pode ser entendida como decorrente da constituição do gênero discursivo que analisamos, o qual pressupõe a necessidade da imagem de um candidato forte e combatente, que procura atacar seu oponente e vencê-lo.

De modo a ilustrar a ocorrência das falácias ad hominem, contabilizamos, comparativamente, esse tipo de estratégia utilizado pelos dois candidatos que concorreram ao segundo turno das eleições para a prefeitura de São Paulo, no ano de 2008:

\begin{tabular}{|l|l|}
\hline MARTA SUPLICY & GILBERTO KASSAB \\
\hline $\begin{array}{l}\text { Oito ocorrências de falácias ad } \\
\text { hominem. }\end{array}$ & $\begin{array}{l}\text { Uma ocorrência de falácias ad } \\
\text { hominem. }\end{array}$ \\
\hline
\end{tabular}

Quadro 8 - As falácias ad hominem.

Por meio da observação do quadro comparativo precedente, é possível observar um dado que pode sugerir um fato relevante e suscitar estudos posteriores acerca do gênero analisado: a candidata que cometeu o maior número de falácias ad hominem não obteve um resultado favorável no pleito eleitoral em os debates políticos eleitorais analisados ocorreram.

Faz-se uma ressalva, porém, no que se refere à contabilização das falácias. De modo a orientar nossas análises, observamos as falácias que julgamos mais significativas no que se refere à sua caracterização explícita, ou seja, aquelas que prescindiram de reformulações que deixassem claro o seu 
caráter falacioso, e que ocorreram no estágio da argumentação (terceiro estágio), descartando outras que necessitariam de uma reconstrução maior e que tiveram lugar nas outras três partes da discussão crítica.

Desse modo, a discussão teórica e as análises permitem-nos afirmar, a respeito do que objetivamos observar sobre a ocorrência das falácias e já delineamos anteriormente, que a ocorrência de determinado tipo de falácia em razão de determinada violação ao código de conduta pode ser oriunda da crença que os interlocutores têm a respeito de seu pretenso efeito na audiência. Sabemos que, empiricamente, pode ser difícil traçarmos, de modo científico, o alcance de um efeito na audiência, mas, em decorrência do contexto e do propósito da interação, entendemos ser possível interpretar que o uso recorrente de uma falácia pode dar-se devido à concepção de que ela atingiria um determinado fim objetivado pelo interlocutor.

Tal fato parece sinalizar na direção de que essa prática discursiva pode ser recorrente devido à crença, relativa aos dados culturais e sociais, de que o auditório seria constituído de interlocutores com pouco conhecimento teórico e/ou escassa capacidade de análise, ocasionando uma espécie de menosprezo à capacidade crítica ou ao ideal de razoabilidade daqueles a quem o debate político eleitoral se dirige.

Pudemos, ainda, depreender de nossas análises que o gênero discursivo observado é altamente propício ao uso de argumentos falaciosos e de ataques pessoais que violam o código de conduta para os participantes de uma discussão crítica, composto das dez regras, conforme proposto pela Pragmadialética, localizado à página 105 de nosso trabalho. 
Finalmente, acreditamos ser importante salientar que, de acordo com o nosso propósito de caracterizar o gênero que compõe o corpus, optamos por uma seleção teórica bastante heterogênea: composta pelos conceitos e definições da Pragmadialética, da teoria bakhtiniana e da tipologia da polêmica proposta por Dascal (1999/2005), conforme exposto no capítulo II.

Essa prática de confluência teórica, constituída por correntes não excludentes, consiste em um dos direcionamentos de pesquisa propagados pelos teóricos da Pragmadialética, os quais defendem que as investigações sobre a argumentação podem buscar modos de observar esse fenômeno linguístico/discursivo que se complementem, propiciando o aprofundamento dos estudos sobre os campos de atividade humana ligados ao ato, intrínseco à linguagem humana, de argumentar. Foi assim que entendemos ter ocorrido com o tratamento dado ao debate político eleitoral, enquanto uma manifestação discursiva polêmica, de constituição específica e essencialmente argumentativa. 


\section{REFERÊNCIAS}

\section{BIBLIOGRÁFICAS}


AQUINO, Z. G. O. (1997). Conversação e conflito - um estudo das estratégias discursivas em interações polêmicas. Tese de doutorado. São Paulo: USP.

(2004). Elementos de Organização do Discurso Político Televisivo: Um estudo do Gênero Debate. In VI CONGRESSO DE LINGÜísTICA GENERAL, Actas. Santiago de Compostela, 3-7 mai. Arco Libros, S.L.

(2005). Diálogos da mídia - o debate televisivo. In: Dino Preti. (Org.). Diálogos na fala e na escrita. 1 ed. São paulo: Associação Editorial Humanitas, v. 7 , p. 171-194.

(2009). As relações de poder no debate radiofônico: discurso, gênero e mídia. Estudos do discurso - diferentes perspectivas. João Pessoa: Idea Editora Ltda, v. 01, p. 1-15.

ARISTOTLE. (1984) The Complete Works of Aristotle: The Revised Oxford Translation, Bollingen Series ; 71:2. Princeton, N.J.: Princeton University Press.

(2005) Arte retórica e arte poética. 17 ed. Trad. Antônio Pinto de Carvalho. Rio de Janeiro: Ediouro.

Tópicos. Disponível em: www.ciberfil.org. Acesso: novembro de 2000.

BAKHTIN, M. (1993) Questões de literatura e estética. A teoria do romance. Trad. A.F. Bernardini et al. 3 ed. São Paulo: Unesp.

(2003) Estética da criação verbal. São Paulo: Martins Fontes.

; VOLOCHINOV, V. (2003) Marxismo e filosofia da linguagem. 11. ed. (Trad. Michel Lahud e Yara Frateschi Vieira). São Paulo: Hucitec.

BARTH, E.M.; KRABBE, E.C.W. (1982). From Axiom to Dialogue. A Philosophical Study of Logics and Argumentation, Berlin/New York: Walter de Gruyter.

BLAIR, J. A.; JOHNSON, R. H. (1987) Informal logic: the first international symposium. University of California: Edgepress.

(1993) Logical Self-defense. Toronto: McGraw-Hill Ryerson.

BRANHAM, R. J. (1991). Debate and Critical Analysis: The Harmony of Conflict Lawrence Erlbaum Associates.

BROWN, P. \& LEVINSON, S.C. (1978). Universals in language use: politeness phenomena. In: GOODY, E. (Org.). Questions and Politeness: strategies in social interaction. Cambridge: C.U.P. (Cambridge University Press), p. 56-289.

CICOUREL, A. (1992) The interpenetration of communicative contexts: example from medical encounters. In: GOODWIN, C.; DURANTI, A. Rethinking context. Cambridge: Cambridge University Press. 
COPI, I. M. ([1953] - 1982). Introduction to Logic. New York: Macmillan. Sixth Edition.

CHARAUDEAU. P. (2006). Discurso das mídias. São Paulo: Contexto. . (2007). Discurso político. São Paulo: Contexto.

DASCAL, M. (1999). A polêmica na ciência. In: GIL, F. (org). A ciência tal qual se faz. Lisboa: Sá da Costa. In: http://retorica-t.blogspot.com/2003/08/tipologiageral-das-polmicas.html, consulta em 11/09/2006.

(2005). Dialogue, Argument, Controversy. Introduction to the SComS: Argumentation in Dialogic Interaction 1-20.

. (2008) A autonomia é uma ilusão. Revista do Instituto Humanitas

Unisinos. $274 . \quad$ Disponível em http://www.ihuonline.unisinos.br/index.php?option=com content\&view=article\&i $\underline{\mathrm{d}=2164 \& \text { secao }=274}$. Acesso em maio de 2013.

DOURY, M. (1995) Duel sur la Cinq : Dilogue ou Trilogue ? IN: PLANTIN, C. et KERBRAT-ORECCHIONI (eds) (1995): Le Trilogue (Lyon: Presses Universitaires de Lyon).

DUCROT. O; ANSCOMBRE, J.-C. (1983). L'argumentation dans la langue. Brussels: Pierre Mardaga.

FINOCCHIARO, M. A.(1996). Two empirical approaches to the study of reasoning. Informal Logic, 16 (1), 1-21.

EEMEREN, F. H. V.; GROOTENDORST, R. (1983). Speech Acts in Argumentative Discussions. Dordrecht: Foris Publications.

(1992). Argumentation, communication, and fallacies. A pragmadialectical perspective. Hillsdale NJ: Erlbaum.

(2001) Crucial Concepts in Argumentation Theory. Amsterdam: Amsterdam University Press.

(2004). A systematic theory of argumentation. The pragma-dialectical approach. Cambridge: Cambridge Univ. Press.

; HENKEMANS, F. S. (1996). Fundamentals of Argumentation Theory. A Handbook of Historical Backgrounds and Contemporary Developments. Lawrence Erlbaum Assoc. Inc Mahwah, NJ: Erlbaum.

; KRUIGER T. (1987) Handbook of argumentation theory; a critical survey of classical backgrounds and modern studies. Dordrecht, Holland; Providence, U.S.A: Foris Publications. 
HOUTLOSSER P. (2002). Dialectic and rhetoric : the warp and woof of argumentation analysis. Boston: Kluwer Academic Publishers.

; GARSSEN, B.; MEUFFELS B. (2009) Fallacies and judgments of reasonableness. Empirical Research concerning the Pragma-dialectical discussion rules. Dordrecht Heildelberg. London New York: Springer.

FÁVERO, L.L. (2001) Coesão e Coerência textuais. 9 ed. São Paulo: Ática.

; AQUINO, Z. G. de O.. (2002) A dinâmica das interações verbais: o trílogo.In: PRETI, Dino (org.) A interação na fala e na escrita. São Paulo: Humanitas/ FFLCH/USP, pp.159-178.

GOFFMAN, E. (1974) Frame analysis. New York: Harper and Row. (1981). Forms of talk. Philadelphia: University of Pennsylvania.

GRILLO, S.V.C (2006). Esfera e campo. In: Bakhtin: outros conceitos-chave. São Paulo: Contexto. P. 133-160.

GROOTENDORST, R. A; HENKEMANS, F. S.; van EEMEREN, F. H. (2002). Argumentation: Analysis, Evaluation, Presentation. Lawrence Erlbaum Associates.

GUIMARÃES, E. (1987) Texto e Argumentação: um estudo das conjunções do português. Campinas: Pontes.

HAMBLIN, C. L. ([1970] - 1993). Fallacies. Vale Press.

KOCH, I. G.V. (1984). Argumentação e linguagem. 3. ed. São Paulo: Cortez. (2003). A inter-ação pela linguagem. 8. ed. São Paulo: Contexto.

LOPES, L. C. (2006) A espiral da opinião comum: a televisão aberta do Brasil, argumentos e culturas. Espéculo (Madrid), Madrid. Disponível em http://pendientedemigracion.ucm.es/info/especulo/numero32/opiniao.html. Acesso em maio de 2012.

MANOSSO, R. (2003) Elementos de Retórica. www.radames.manosso.nom.br/retorica/index.htm, consulta em 20/04/2006.

MARCUSCHI, L. A. (1986). Análise da conversação. São Paulo: Ática.

OSAKABE, H. ([1979] - 2002). Argumentação e discurso político. São Paulo: Martins Fontes.

PERELMAN, C.; OLBRECHTS-TYTECA, L. ([1958] - 2002) Tratado da argumentação. A nova Retórica. São Paulo: Martins Fontes. 
PLANTIN, C. (2008) A argumentação. História, Teorias, Perspectivas. Trad. Marcos Marcionilo. São Paulo: Parábola.

POSSENTI, S.; PASSETI, M.C. (2010) Estudos do texto e do discurso: política e mídia. Maringá, Paraná: Eduem.

RUBIM, A. A. C. (2000) Comunicação e Política. São Paulo: Hacker Editores. (2004) Espetacularização e Midiatização da Política. In: RUBIM, A.A. C. (org). Comunicação e Política: Conceitos e Abordagens. Salvador: Edufba. p. $181-221$.

SANTOS, E. M; ROMUALDO, E. C. (2010) Midiatização e espetacularização: os entornos da mídia na campanha eleitoral de Lula em 2002. In: POSSENTI, S.; PASSETI, M.C. (org.) Estudos do texto e do discurso: mídia e política. Maringá: Eduem. p.123-148.

TINDALE, C. Fallacies and Argument Appraisal, Cambridge: Cambridge University Press, 2007.

TOULMIN, S. ([1958] 2001) Os usos do argumento. São Paulo: Martins Fontes. Macmillan.

(1976) Knowing and Acting. An invitation to Philosophy. New York:

WALTON, D. N. (1992). The place of emotion in argument. S.L: Pennsylvania State University.

(2006) Lógica Informal. Trad. Tradução de Ana Lúcia R. Franco e Carlos A. L. Salum. São Paulo: Martins Fontes.

University Press.

(2006) Fundamentals of critical argumentation, Cambridge: Cambridge

WITTGENSTEIN, L. (1979) Investigações Filosóficas. 2 ed. Trad. José Carlos Bruni. São Paulo: Abril Cultural. (Os Pensadores).

YAÑEZ, C. S.; MARAFIOTI, R. (org.) (2008) De las falácias. Argumentación e comunicación. Buenos Aires: Biblos. 
ANEXOS 


\author{
ANEXO 1 \\ Programa exibido no dia 11 de setembro de 2008, com duração de cento e \\ quarenta minutos e vinte e cinco segundos. \\ L1: Boris Casoy. \\ L2: Ivan Valente. \\ L3: Glberto Kassab. \\ L4: Soninha Francine. \\ L5: Renato Reichmann. \\ L6: Marta Suplicy. \\ L7: Ciro Moura. \\ L8: Geraldo Alckmin. \\ L9: Paulo Maluf. \\ L10: José Paulo de Andrade. \\ L11: Fernando Vieira de Mello. \\ L12: Sônia Blota. \\ L13: Patrícia Zorzan. \\ L14: Eudes Júnior. \\ L15: Fernando Mitre.
}

((música de abertura junto com a apresentação dos nomes dos candidatos))

L1: Soninha Francine... do Pps... ReNAto Reichmann... do Pmn... MArta SupliCY... do Pt... Ciro MoURA... do P-T-C... Geraldo ALckmin... do Psdb... e Paulo Maluf... do Pp... as regras do deBAte foram aprovadas pelos assessores de TOdos os candidatos... vamos ver agora COmo será este pri-mei::ro bloco... uma perGUNta do mediador que será resPONdida por TOdos os candidatos em ordem já defiNIda por sorteio... tempo de UM minuto e me::io:: para a resposta... lembramos que durante o deBAte POde ser conCEdido direito de resposta em caso de ofensa moral ou pessoal... o pedido deve ser feito LOgo após a suPOsta ofensa... e a decisão de atender OU NÃO... será de uma comissÃO especialmente escolhida pela Band que se encontra em lugar reserVAdo nos bastidores... pela ordem do sorTElo já realizado na presença dos assessores... o candidato Ivan Valente será o primeiro a responder... eu lembro que o TEMpo para a resPOsta é de UM minuto e MElo... a pergunta foi escolhida a partir dos temas SUgeridos pelos leitores do jornal MEtro e é a seguinte: ... QUAis as medidas conCREtas que serão TOmadas na sua administração para melhoRAR o TRÂNsito e o transporte coleTIvo na cidade?

L2: boa noite a todas e a todos:.... queria em primeiro lugar agradecer a tv Bandeirantes por essa oportunidade e porque... esse é o único momento efetivo da campanha do confronto diREto de ideias... a grande oportunidade da esCOIha do eleitor através do deBAte prograMÁtico... em relação à pergunta feita... eu queria iniciar dizendo que... quem disser que vai resolver o problema do TRÂNsito e do transporte à curtíssimo PRAzo não está falando a verdade para a população... e nós:.... vamos colocar claramente que nós vamos SUBSIdiar o transporte... nós NÃO vamos subsidiar a indústria automobilística... que recebe TRÊS virgula dois Bllhões de subsídio federal para colocar e lacrar setecentos carros por ano aqui em São Paulo... nós vamos colocar a necessidade do diRElto à mobilidade PAra O trabalhador... tarifa ZEro em São Paulo... vamos investir peSAdo no transporte PÚblico de massas... o meTRÔ e TREM... vamos criar uma empresa MUNIcipal dos transportes para administrar os COrredores de ônibus... aumenTANdo à velocidade... ISSO para nós é inverter PRIOridades... isso é mostrar que São 
Paulo não precisa de OUtro GErente para a cidade... precisa de OUtro projeto político...

L1: o segundo a responder por ordem de sorteio é o candidato GilBERto KaSSAB...

L3: boa noite telespectadores... boa noite Boris... boa noite candiDAtos... candiDAtas... é um dos temas MAis importantes DEssa eleição... e um dos assuntos MAis preocupantes da cidade de São Paulo... um dos assuntos que mais afligem o paulistano... a solução é: transporte público de qualidade... metrô... corredor de ônibus... há trinta anos a cidade de São Paulo não investia através da prefeitura no metrô... diVERsos prefeitos que me antecederam prometiam que iam investir no metrô... na MInha gestão serão UM bilhão de reais no metrô... corredores de ônibus... temos que fazer corredores de ônibus como DEvem ser feitos... sem interferências isto é... sem cruzamentos... nos pontos de parada... com área para ultrapassagem... para que o cidadão possa fazer o seu percurso com o tempo mínimo de viagem... sendo portanto incentivado a deixar o seu carro em casa e usar o ônibus... e investimentos também de:: curto prazo... como a recente restrição de circulação de caminhões no centro da cidade... enFIM... transporte público de qualidade... nós TEmos que acreditar que a cidade de São Paulo POde melhorar... como tem melhoRAdo na nossa gestão... na saÚde... na educaÇÃO... no campo sociAL... na habitaÇÃO... na saúde com as Amas... com dois novos hospiTAis... com a contratação de três mil MÉdicos... enfim... São Paulo tem jeito... o TRÂNsito também tem jeito... o que precisamos é saber ENfrentar as adverSIdades... enfrentar as corporações... e apresentar para a cidade de São Paulo um transporte público de qualidade...

L1: responde agora a candidata Soninha Francine...

L4: obrigada boa (noite) a gente precisa atuar em pelo menos três eixos... no transporte coletivo... na engenharia de tráfego... e na reorganização do território... transporte coletivo naturalmente com mais metrô:.... mais corredores de ônibus... melhorar o serviço à noite e nos fins de semana porque é muito preCÁrio... a loGíStica... a organização das linhas de ônibus... às vezes as pessoas são obrigadas a fazer viagens DESnecessárias em direção ao centro da cidade... por falta de uma linha entre os bairros ou entre as regiões da cidade... então tud/ tudo isso precisa ser melhorado... o conforto... a acessibilidade... universal... dos veículos... dos pontos... dos terminais... a inFORmação sobre o sistema de ônibus... porque hoje para você descobrir que ônibus pega e onde desce e quanto em quanto tempo ele passa... é um desaFIO... as informações não são BEM ofereCldas... tem que ter informação no ponto de ônibus... por telefone... na internet... até em mapa de bolso... então tem uma SÉrie de coisas nessa linha do transporte coletivo... na engenharia de TRÁfego a Cet precisa de mais recursos financeiros humanos tecnológicos... a gente precisa de mais seMÁforos eletrônicos... uma sinalização melhor na cidade toda... precisa melhor as condições de circulação de motos bicicletas e pedestres porque muitas viagens diárias são feitas essa maneira e precisa estudar muito bem... ah... o estu/ o impacto de vizinhança antes de conceder licença prum novo empreendimento ver o quanto ele vai interferir $n$ trafego da região... e por fim... diminuir as distâncias da ciDAde... a gente tem bairros muito pobres onde quase não tem atividade econômica neNHUma... e outros que concentram toda a estrutura urbana... tem que diminuir as distâncias senão o transporte não dá conta...

L1: a seguir o candidato Renato Reichmann...

L5: DUas medidas de curTIssimo prazo que DEZ minutos DEpois de enTRAR na prefeiTUra podem ser implantadas... a priMEIra... que se usa no mundo inteiro... taRlfa reduzida fora do horário de pico... tipo de oito à cinco da TARde invés de 
custar dois e trinta custa um e seTEN::ta... é só dar um comando no computador... falar a partir deste horário a passa/ só desconta um e senTENta um e sesse/ um e oitenta do bilhete... a outra medida insTANTÂnea... -- que eu não entendo porque não é feita até hoje -- TOdas as estações de rádio e tevê utilizam... para monitorar o trânsito... helicópteros... o Cet só precisa fazer um conVÊNIO com as empresas... com certeza terão o PRAzer de levar o pessoal... de prestar mais um serviço para a cidade -- que já presta há muito tempo -- de colocar um TÉCnico lá em cima... com BINÓculos e um RÁdio... orienTANDO seus colegas embaixo como desviar e orientar o trânsito isso alivia demais... tem mais TRÊS medidas... algumas de médio prazo... uma É realmente colocar alGUMAS linhas exPRESSAS no corredor de ônibus pra aumenTAR a capacidade do sistema e evitar que a pessoa que vai de PONta a PONta tenha que parar de PONto em PONto desnecessariamente... cons-tru-ção:: de garagens em pontos próximos das estações principais permitindo fazer o re/ percurso loCAL com o próprio carro e a distância maior de transporte coletivo... e a aberTURA de alças de acesso no RodoANEI... permiTIN::DO a/ o desenvolvimento econômico de regiões mais perifÉricas com melhor aCEsso... vai gerar atividade econômica... as pessoas vão poder trabalhar MUlto mais perto de casa... que é um dos problemas... e COM isso aliviam também o transporte e melhora a qualidade de vida.

L1: obrigado candidato... os candidatos estão respondendo à seguin::te pergunta... QUAis as medidas conCREtas que serão toMAdas na SUa administraÇÃO para MElhorar o TRÂNsito e o transporte coletivo NA cidade... a próxima a responder é a candidata MARta Suplicy...

L6: Boa noite... quero agradecer a Band a essa oportuniDADE... aos:: colegas adversários... outros candidatos que aqui estão... e você em casa que está nos assistindo... são três as medidas que tem que ser tomadas no DIA seguinte da eleiÇÃO... com resultado à CURto... MÉdio e longo prazo... a cur::to prazo é investir na Cet e na Sptrans para recuperar a capacidade de gesTÃO delas... que são as enti/ as entidades que fazem o trânsito FLUIr na cidade... contratar marronzinho... porque se hoje você tem o CArro que estraga na MargiNAL... que PAra... não tem ninguém para tirar e ficam quilo::metros... né?... à curto/ à médio prazo nos temos que investir nos correDORES... nós investimos em CEM quilômetros de corredor... a atual gestão investiu em DEZ... isso teria ajudado MUlto... ahn:: conseguir ter investido em corredores... e a longo prazo é o meTRÔ... quando fui preFEITA a cidade não tinha condição de investimento agora TEM... eu conversei com o presidente Lula... ministra Dilma... quando eu ERA ainda ministra... e foi levada a eles em PLAno para investimento em metrô em São Paulo... porque sem isso nós não temos condição de abrigar a Copa de dois mil e quatorze... o plano foi aproVAdo e eu espero que após as eleições o plano/ o Pac da mobilidade urBANA vai poder ser apresentado... e nós vamos então ter/ ter PAULAtinamente uma situação meLHOR aqui no trânsito da cidade de São Paulo e quem cuiDOU dessa cidade e arruMOU o que era o trânsito e o transporte nessa cidade tem condição de fazer tudo isso...

L1: obrigado candidata... seGUINdo a ordem estabelecida no sorteio:.... é a vez do candidato Clro Moura...

L7: boa noite Boris... boa noite candidatas e candidatos... senhoras e senhores telespectadores da rede Bandeirantes... é excelente oportunidade para nós começarmos/ a auferir propostas... transporte... evidentemente nós não conseguiremos nada sem ter um transporte público eficiENTE... isto envolve o meTRÔ... que por algum motivo que eu não consigo entender... ele anda mui::to devagar... a cidade do México começa seu metrô no mesmo ano em que nós começamos... hoje ela tem duzen::tos e vinte quilômetros de metrô e São Paulo 
amarga sessenta quilômetros... vejam os seNHOres que nós temos que... entender as propostas e promessas como algo facTíVEL... tem sido prometido... não resta duvida nenhuma que é importanTíssimo... que não só a prefeitura vai conseguir resolver... a participação da União e do Estado... têm sido dito que o Estado vai entrar com TANto... a prefeitura com TANto... e a União com tanto... e de repente nos deparamos com o orçamento da União que não prevê UM tosTÃo para o metrô de São Paulo... como É que se vai cumprir uma coisa dessas se a União já se afastou do problema?... não tem um tostão no orçamento... então vejam os senhores... meTRÔ... Rodoanel fato imporTANTE para evitar o trânsito em São Paulo PARAdo... não anda... é o metrô... o Rodoanel TARtaruga... ora... nós precisamos assumir posições claRísSImas...

L1: agora é a vez de responder do candidato Geraldo Alckmin...

L8: boa noite BOris... boa noite candiDAtas e candiDAtos... boa noite a você que está em CAsa nos assistindo... nos ouVINdo... em relação à questão do transporte e do TRÂNsito... é o investimento no transporte coleTlvo... a responsabilidade da prefeiTUra é Ônibus... há nove Mllhões de viagens de passageiros por DIA... um sistema ineficiente... passagem cara... ônibus superlotado... as pessoas levando QUAse QUAtro horas entre vir e voltar para o trabalho... talvez o maior sacrifício... isso tudo mostra a ineficiência do sistema... nós vamos construir os corredores com ultrapassagem... dar PRloridade aos ônibus... seMÁforos inteligentes... obras FÍsicas de integração... apoiar o metrô... que precisa ser expandido com dinheiro da prefeiTUra e de operações urBAnas... dinheiro priVAdo... por Ppp... construir as garagens subteRRÂneas para TIrar os carros da rua para dar maior fluiDEZ... a ligação da Jacupessego com a asa SUL do Rodoanel está PLEnamente em obras... está indo MUlto bem... e deve ficar pronto agora em dois mil e dez... e aí já se FEcha o anel entre a Ayrton Senna e a Jacupessego até... ah... o porto de SANtos... e o Rodoanel sul... eh... as Clclovias que são importantes... a integração dos modais... o TREM que nós levamos ao Grajaú... ir agora até VarGInha no extremo sul... são... a integração de TOdos esses modais... e PRIN:ci:pal:mente o ônibus...

L1: o próximo a responDER é o candidato PAulo Maluf...

L9: boa noite Boris... boa noite telespectadores... aqueles que chegaram aqui hoje em TEMpo... neste deBAte sabem que TRÂNsito e transporte coletivo foi o forte sempre do prefeito e do governador Paulo Maluf... ou vocês vieram pelos TÚneis que a gente construiu com muita coragem... ou pelas avenidas... ou vieram pelo metrô... que Paulo Maluf e Faria Lima começou... a linha norte-SUL... ou se vieram pela linha leste-oeste... todas as estações que eu inauguREI... os TERminais de ônibus... e também todos os corredores... ora... o processo é político... não se anda nesta cidade um quiLÔmetro sem andar numa obra do Paulo Maluf... agora... muita gente promete... todos os candidatos prometem tudo... mas QUEM pode realizar?... se o processo é político e nós estamos numa eleição... nós temos que saber que as pesquisas dão trinta e nove pontos pra quem?... para a ex-prefeita Marta Suplicy... que foi derrotada quatro anos atrás exatamente porque o povo não apr/ não aprovou a gestão dela... ora... sessenta e um por cento se dispõe a não votar nela... é neste confronto do segundo turno... onde se ela for ela tem dez minutos... e EU tenho dez minutos... que eu vou mostrar ponto por ponto que eu tenho as meLHORES condiÇÕES de resolver os proBLEMAS do transporte coletivo porque... com vinte e QUAtro bilhões em fiz MAIS em QUAtro anos do que todos os prefeitos que sucederam com cento e cinqüenta bilhões... é PAUlo MaLUF para venCER MARta no seGUNdo TURno e resolVER o problema do transporte coletivo e do trânsito...

((vinheta musical junto com a fala do apresentador)) 
L1: no próximo bloco CANdidato pergunta para CANdidato... eleições dois mil e Olto... debate... voCÊ deClde na Band...

(( intervalo comercial))

(( vinheta musical anunciando o reinicio do programa))

L1: e voltamos com o deBAte entre os candidatos à prefeitura de São Paulo... participam desta transmissão ao VIvo a BAND News tv... e as rádios BandeiRANtes Am e Fm... e Band News Fm... o deBAte também pode ser acompaNHAdo pela internet... veja agora as REgras deste seGUNdo bloco... candiDAto pergunta para candiDAto em ordem já definida por sorteio... pergunta de TRINta segundos... resposta de UM minuto e meio... RÉplica e TRÉplica... um minuto cada... a primeira a perguntar neste bloco é a candidata MARta Suplicy... a senhora pode escolher o candiDAto e fazer a pergunta...

L6: é... minha pergunta é para Geraldo Alckmin... no seu governo... Alckmin... São Paulo viveu a pior CRIse de segurança... foram centenas de rebeliões na FeBEM... CHAcinas... e nós vivemos uma situação trágica com o Pcc... nessa época o seu PARtido não ajudou... pois extinguiu a secretaria de segurança da cidade de São Paulo... e suCAteou a GUARda municipal... a minha pergunta é... QUAL a sua posição sobre a atitude do seu partido na prefeiTUra?... o que você pretende fazer com a GUARda na cidade de São Paulo?...

L8: olha... se há uma área que nós podemos nos orgulhar MUlto é seguRAN::ça PÚblica... porque no ano de dois mil nós tínhamos DOze mil oitoCENtos e oitenta homicídios... talvez a candidata Marta não SAlba... ela não acomPAnha a questão da criminalidade... mas nós reduzimos de doze mil para onze mil... dez mil... nove mil... oito mil... sete mil... seis mil... cinco mil... o ano passado foram quatro mil:: oitocentos e oitenta... isso nós nos orgulhamos... quantas VIdas não foram salvas... São Paulo deu o EXEMplo para o Brasil de traBALHO... o Carandiru hoje não EXISte mais... hoje é o PARque da Juventude com escolas técnicas... com Fatecs... invesTImos no sistema prisioNAL... por isso sim caíram os índices de criminalidade... quando o governo federal... do partido dela não tinha onde colocar o senhor Fernandinho Beira-Mar... SÃO Paulo abrigou... em penitenCIÁria de segurança MÁxima... era pra ficar TRINta dias... ficou DO::is anos aqui... eu aSSUmo responsabilidade... a candidata Marta... NÃO... ela era prefeita... ela TInha que receber os JOvens em situação de RISco da Febem... NÂO recebeu... foi depois o governo SErra na prefeitura... que AI SIM... os jovens que não precisavam ficar em situação de privação da liberdade... a prefeitura abrigou... não cumPRIU com a sua obrigação... vem jogar pedra... e quero dizer a vocês que vou me empeNHAR... na prefeitura de São Paulo... com deZOlto mil câmeras de vídeo... DEZ mil guardas civis...

L1: RÉplica da candidata Marta...

L6: me espanta a resposta porque parece que nós vivemos em cidades diferentes... em realidades diferentes... na sua época Alckmin... as crianças a maior índice de mortalidade de DEZ a quarenta e nove anos foi homiCÍDIO... e São Paulo viveu uma situação com o Pcc que parece que você esqueceu... foi páginas até internacionais e a gente ficou sitiado em CAsa... eu na prefeitura CRlei a secretaria de segurança -- o que você não respondeu se vai criar ou NÃO -porque seu partido extinGUIU... E reequiPEl toda a guarda municiPAL... e ela agora $\mathrm{t} /$ tudo isso foi extinto na gestão Serra-Kassab... a secretaRIA... as bases comuniTÁrias... nós criamos quaRENta e três guardas comunitárias que estão praticamente abandonadas... e eu acho muito importante quando se fala em preven/... de crime... homicídio e tudo o MAis... tem que fazer proJEtos sociais e colocar a guarda municipal como prevenção... e isso nós fizemos na prefeitura e o resultado foi fantástico... com diminuição de homicídio na periferia... 
L1: TRÉplica do candidato Geraldo Alckmin...

L8: a própria candidata está dizendo que os homicídios CAÍram... eh... alias o índice de homicídio no BraSIL CAlu em razão de São PAUlo... porque a redução em São Paulo foi de seTENta e DOis por cento no número de homicídios... nós nos orgulhamos deste trabalho... invesTImos no sistema prisional... presos inclusive trabaLHANdo... hoje quá/ mais de quaRENta por cento dos presos trabalham... QUAse vinte por cento dos presos condenados eles estudam... não há um preso em caDEla aqui em São Paulo... acabamos com preso em distrito policial... e como prefeito vou ajudar o Governo do Estado... a guarda civil metropolitana vai ser inteGRAda com a Polícia Civil e Militar... trabalhar junto... trabalhar nos bairros... vou colocar guarda nas escolas... nas unidades de saúde... nos terminais rodoviários... fui a Bogotá... tive com o general Oscar Marenco... éh... da força nacional... vamos instalar dezoito MIL câmeras de vídeo... com software para poder monitorar as áreas... você que está em casa vai ter MUlto mais proteção...

L1: o próximo a PERguntar é o candidato Geraldo Alckmin...

L8: eu pergunto pra candidata Marta... o governador Mário Covas foi um dos precurSOres da responsabilidade com o SEU dinheiro... o dinheiro da população... eh... de São Paulo... e depois veio a Lei de Responsabilidade Fiscal... nós já reduZImos até os impostos... PÃO em São Paulo reduzi para ZEro... trigo zero... farinha de trigo zero... macarrão zero... álcool combustível reduzi para doze... a candidata do Pt aumentou os impostos e as taxas e deixou um rombo de um virgula oito biLHÃO de reais nas contas publicas do município

[

L6:

al/...

L8: como é possível?...

L6: Alckmin... primeiro a redução de que você está falando... hoje está sendo toda questionada pelo atual governador Serra... bom... mas eu vou falar da nossa prefeitura que nós pegamos FAlida... acaBAda pela gestão Maluf-PItta... e que tivemos que paGAR as dívidas... e depois disso começar a organiZAR a ciDAde... nós conseguimos terminar o nosso mandato criando bilhete único... fazendo o Ceu... fazendo o maior programa social DO Brasil... e assim mesmo deixando um SUperávit de noventa e um milhões... e:: também em caixa... trezentos e cinquenta e oito milhões... vocês fizeram do Psdb... processos... foi para o Supremo Tribunal Federal onde foi arquiVAdo... dizendo que cumprimos sim a lei da responsabilidade fiscal... e o que aconteceu... para comprovar isso... no final da gestão de janeiro vocês já tinham UM bilhão no CAlxa da prefeitura... termiNARAM o ano com supeRÁVIT... superávit já tendo pago todas as contas... supeRÁvit... né?... de DOis bilhões e pouco... depois três bilhões no outro ano... e agora tem... no no banco... QUAtro bilhões... essa gestão é uma gestão... éh:: do Psdb e Demo mas uma gestão que deixa dinheiro para os banQUEIros... invés de pôr dinheiro em CREche... em reMÉdio... fazer correDOR... tudo o que está sendo preciso... nós fizemos uma gestão que foi realmente muito boa para quem tinha POUcos recursos... comparada com quem hoje tem DEZ bilhões a mais do que nós tivemos na época...

L8: a verdade

L1: [replica... pois não... pois não...

L8: a verdade é BEM diferente... final da gestão... déficit de DOis vírgula um bilhões... exatamente... tira os trezentos milhões em caixa... o déficit Líquido um 
vírgula oito bilhão... todas as obras paRAdas... viaduto lá da Jacupessego... parado... hospital que não saiu do chão... éh... não pagou conta de enerGIA da SaBESP... aliás é impressionante... criou a taxa do/ da LUZ... cobrou de quem não tinha iluminação pública... e não pagou a conta de energia... é a má gestão completa... cria a TAxa... cobra de quem não tem... e não paga a conta de energia... quer dizer é um caos verdadeiro... éh... um absurdo eh... essas pessoas/ DOis mil e VINte e selS credores não receberam... aliás alguns não receberam até HOje... porque as dividas foram parceLAdas em SEte anos... o meu compromisso com você... que paga impostos com sacrifíclO... é boa gestão... eficiência no gasto PÚblico... fazer MAis... fazer meLHOR... e não deixar para o sucessor uma situação de dificuldade...

L1: tréplica da candidata Marta Suplicy...

L6: Alckmin eu não vou ficar discutindo os números com você porque os números/ que você falou não são os números verdadeiros... então vai ficar os meus contra os seus... né?... os meus foram inclusive reconfirMAdos pelo Supremo Tribunal Federal e foi feito um clima de terror eXATAmente para colocar a nossa administração com uma MÁ face... quando a nossa administração PAgou... deixou dinheiro/ para pagar o que deVIA e vocês terminaram o ano/... o... jaNEIro com cem milhões... agora... eu fico muito contente de com pouco recurso... ter podido fazer o que eu fiz... porque eu peguei essa cidade... um CAos... parecia que tinha passado um bando de gafanhoto... desde o sistema de saúde que nós tivemos que municipalizar inteiRInho... e conseguimos um Êxito conseguindo diminuir mortalidade maTERna... infantil acabando a DENgue... fazendo programas para as mulheres muito bons... até o transporte que fizemos o bilhete único... que hoje é copiado em vários países... além dos Ceu... que foi realmente um grande plano de incluSÃO social... e de mudança na nossa periferia...

L1: quem pergunta aGOra é a candidata Soninha Francine...

L4: pro candidato Paulo Maluf::... corrupção é um problema seríssimo... porque desvia recursos públicos... prejudica a qualidade dos serviços... dos atendimentos... das obras... porque é muito injusto com quem é honesto... porque cria facilidades para quem não não faz questão de sê-lo e porque CRla todo um clima de descrença na política e nos políticos que faz muito mal... eu queria saber quais as propostas do candidato para combater a corrupção na máquina pública...

L9: para não deixar transitar em julgado... em tenho antes de responder à sua pergunta... um gráfico aqui... que vou deixar depois com a imprensa... que mostra que em primeiro lugar... dona Marta não substituiu a mim... ela não teve... gestão Maluf antes dela... segundo lugar eu vou mostrar que as gestões que MAis endividaram a prefeitura... que deixaram a prefeitura quebrada... foram as duas gestões do Pt... dona Luiza Erundina em oitenta e oito e Marta Suplicy em dois mil e quatro... ou seja... ela deixou o maior índice de endi/... viva/ de endividamento e a maior iliquidez... segundo... sobre corrupção Soninha... eu acho que você está na ordem do dia... porque... os jornais estão dando que você que é vereadora... portanto você que perTENce à Câmara de Vereadores... você diz que os vereadores se vendem por dinheiro... ora não tem corrupção sem ter corruptor... então eu gostaria que você tivesse coragem... agora... para dizer quais são os seus colegas que se vendem por dinheiro e quais foram os prefeitos que pagaram... EU não fui... porque você não foi vereadora comigo... os prefeitos que me sucederam... se houve corrupção pagando à Câmara Municipal como você MUlto bem DI::sse claramente... mas não teve coragem de dar nomes aos bois... eu te desafio... dá nome aos bois... os teus colegas corruptos e quais foram os prefeitos que PAgaram... eu não porque você não foi prefeita... não foi vereadora comigo... 
L4: minha vez?...

L1: sim senhora...

L4: ninguém precisa ter sido vereador pra saber que se negoCIAM votos NOS parlamentos... e foi isso que eu disse na sabatina do Estadão... na Câmara MuniciPAL... em assembléias legislatiVAS... no Congresso NacioNAL... infelizmente nós temos casos sendo julgados inclusive no Supremo Tribunal Federal de trocas de votos por favores financeiros... pra combater a corrupção eu acho que... é claro que é importante puNIR os autores de desVIOS... de má conDUTA... mas eviTAR ocasiões para a prática de corrupção também... a burocraCIA na máquina pública POR exemplo CRIA a/ condiÇŌES pra/ pra vários intermediÁRIOS é tudo tão comPLIcado... é tão difícil aPROvar uma planta... obter um alvaRÁ... conseguir plena condição de funcionamento de um estabeleciMENto... que é... E muito tentador... aparece muita gente no meio do caminho para encurTAR... pra tornar tudo mais rápido... pra se oferecer para facilitar indevidamente... então a gente precisa desburocratizar... informatizar... tornar os processos... os procedimentos todos mais SIMples e mais lógicos... para evitar a ocasião propícia para a ocorrência de corrupção...

L9: veja... você não teve coraGEM... de dizer quais são os seus colegas de Câmara Municipal... que convivem com você quatro anos... e recebe dinheiro como você aCUsou... e não tem coragem de dizer quais foram os prefeitos que fizeram isso... agora o que eu posso dizer para você... que eu fui prefeito... QUAtro anos... QUAtro anos com seis bilhões de orçamento... EU fiz... e com vinte e quatro bilhões... MAis do que TOdos aqueles que me sucederam com centro e cinQUENta... e pode somar o governador Alckmin junto... que eu fiz mais do que todos juntos... ora... se eu fiz mais do que todos juntos... com menos dinheiro... eu te pergunto... você que é vereadora agora... onde é que está o dinheiro das administrações atuá/?... porque eu fiz MAis com menos... você não chega aqui sem um túnel do MaLUF... sem uma avenida do MaLUF... sem o metrô do MaLUF... sem uma obra do Paulo Maluf... e fiz isso com MUlto pouco dinheiro... e tem uma coisa para voCÊ... eu entrei na política rico... muito rico... graças a deus... e hoje posso dizer que estou menos rico que estava...

L1: a próxima a pergunTAR... o próximo a perguntar neste bloco é o candidato Renato Reichmann...

L5: eu gostaria de perguntar pro prefeito Gilberto Kassab... prefeito... éhn:.... nós temos um problema que se perpeTUA há trinta anos ou mais::... de acordo com quem conta... são de cinco a quinze MIL crianças na rua... isso é um fracasso para a gente como sociedade... como pessoas... como políticos... como profissionais... acho absolutamente inadmissível... qual seria o projeto pra... num prazo de seis meses ou um ano... depois do começo da gestão não haver mais uma única criança na rua... se é que há um projeto desse tipo...

L3: obrigado Renato... uma pergunta muito importante... a cidade de São Paulo é uma das cidades mais avançadas do país... ela precisa investir muito... mais muito... no social... e no social significa TAMbém educaÇÃO... saÚde... além de assistência social... tivemos oportunidade nessa gestão de melhorar... de recuperar nossos equipamentos públicos voltados para essas crianças...e estabelecer uma política de INtegração das ações da secretaria da saúde... da secretaria da educação... com a secretaria da assistência social... com diVERas ações no campo da saúde... no campo da saúde psiquiátrica... pra que pudéssemos reduzir o número de menores nas ruas... e foram reduzidos de maneira SIgnificativa... e esperamos ao longo da próxima gestão melhorar MAis ainda esses índices... como aliás melhoraram em outras ações da prefeitura... em outras áreas vinculadas à saúde e educação... construindo essas ações de uma 
maneira inteGRAda... nós vamos Efetivamente construir o caminho da solução deste problema... eu quero dizer a você que... quando você constrói cento e quinze Amas na cidade de São Paulo... dois hospitais... quando você contrata três mil médicos... quando você caPAcita os nossos assistentes sociais... e os nossos programas de capacitação foram MUlto intensos e muito... eh... integrados com estas duas áreas... nós estamos próximos de resolver esse problema que é próprio dos grandes centros urbanos... isto é... das grandes cidades do mundo... e SÃO Paulo é a terceira cidade do mundo...

L1: senhor Reichmann... sua réplica...

L5: prefeito... ahn... um dos problemas... TANto quanto tirar a criança da rua é tirar a rua da criança... o senhor apoiaria um projeto onde se coloCAsse... porque a rua é muito interessante para a criança é a liberdade total... mas ter família também... o senhor aprova/ aprovaria um programa... que coloCAsse essas crianças em famílias tipo creches ou orfanatos dentro da comunidade... mas unidades muito menores do que isso... não estamos falando de um volume grande... porque são de cinco a quinze mil crianças só... e que ao mesmo tempo em que tiramos essa criança da rua... e não de/ e monitoramos para que não ha/ haja refluxo também gera renda na comunidade... gera uma responsabilidade/ social... a... MÃE-crecheira... a babá-governanta... cozinheira... todo mundo que tem lá... vai receber o dinheiro da prefeitura... gera recurso DENtro da comunidade... resolvemos dois problemas de uma vez só...

L3: você... você abordou uma questão MUlto importante na cidade de São Paulo que é a questão das creches... São Paulo no início de nossa gestão tinha seSSENta e uma MIL vagas em creches... HOje... nós temos cento e cinco mil vagas... e o nosso compromisso é eliminar o déficit de creches da cidade de São Paulo ao longo da próxima gestão... É evidente que todas as soluções por você lembradas aqui... elas são positivas... poRÉM... o que precisa haVER... é o compromisso... é a integração com a sociedade civil... para que ela possa atender essa demanda... se ela não puder atender a demanda em função das ideias por você apresentada... a responsabilidade é do poder público... e nós... ao longo de nossa gestão... cumprimos a nossa responsabilidade... retiRAmos os menores das ruas... diminuímOS esses índices... e vamos continuar avanÇANdo... nesse programa que é uma prioridade da nossa gestão... não deixa de ser também um programa voltado à melhoria da educação porque educação de qualidade significa... antes de mais nada... você dar melhores condições às crianças... sejam aquelas que não têm uma creche hoje e precisam ter... sejam aquelas que estão na rua e precisam ter uma oPORrtunidade de sair da rua...

L1: quem pergunta agora é o candidato Paulo Maluf...

L9: Boris... ((limpa a garganta)) gostaria de perguntar a dona Marta... ao exgovernador Alckmin... ao prefeito Kassab mas o regulamento não permite porque quem já foi perguntado não pode ser perguntado novamente... então eu vou perguntar ao candidato Reichmann o seguinte... quando eu fui governador... São Paulo tinha duas creches... nós construímos com o prefeito Reinaldo de Barros... duzentas e quarenta creches... quando fui prefeito... construí mais duzentas e oitenta creches... ou seja... hoje a mãe trabalha e precisa deixar a criança em algum lugar... qual é o seu programa para creches?...

L5: São Paulo... como TUdo que é de São Paulo... TUdo é de uma ordem de grandeza enorme... hoje nós temos... provável/ os números variam muito mas provavelmente duZENtas mil a duzentas e cinquenta MIL crianças sem vagas de creche... isso significa construir alGUma coisa... se considerarmos uma média de vinte e cinco crianças... de vinte e cinco a cinqüenta crianças nós estamos falando de construir CINco a DEZ mil uniDAdes para as crianças TErem onde fiCAR 
durante o dia ESpecialmente na faixa de zero a quatro... que é a base FUNdamental para o desenvolvimento da criança... e isso não é possível sem o en/ envolvimento da sociedade civil... tem que descentraliZAR a prefeitura... ahn... a prefeitura central tem que ser um FORmulador de políticas... o executor da política tem que ser a administração regional... a prefei/ a sub-prefeitura... aí sim começamos a maClçamente a construir... num volume como não se viu antes... de maneira MAis econômica possível... aproveitando o que já existe de equipamento e investindo EM peSSOas... que é um investimento muito mais eficiente até socialmente do que só construir porque só construir não colocar ninguém dentro também não resolve o problema... então é melhor ter uma instalação NÃO tem perfeita... mas pessoas qualifiCAdas e motivadas e isso vem atravé/ e a prefeitura fazendo a parte dela que é GErir o processo e não a atividade fim...

L1: RÉplica do candidato Paulo Maluf...

L9: nesses últimos QUArenta anos... o número de mulheres que veio... graças a deus... para o mercado de trabalho foi muito grande... aumenta a renda familiAR... aumenta o Produto Interno Bruto do paíS... reSOLve problemas sociais... mas é evidente... que a mãe precisa deixar a criança em algum lugar... então meu projeto que FIZ... além da construção das CREches... com atividade diREta da prefeiTUra... terceriZAR... QUANtas entidades de volunTÁrios eXIStem... que com uma peQUEna contribuiÇÃO... um peQUEno conVÊnio da prefeitura... vão cuidar quem sabe com carinho igual ou até meLHOR as crianças que ficam lá... do que as creches municipais... então eu pretendo sim... eu acho que existe cerca de cinquenta mil crianças que não têm vagas nas creches... temo que construir ou terceiriZAR MIL creches... e se for prefeito... a MÃE de São Paulo pode saber... vai ser minha prioridade...

L1: tréplica do candidato Renato Reichmann...

L5: bom... o número acho que é bastante maior que cinquenta mil... está bem acima de cinquenta mil... a questão é que nós temos que tomar uma decisão como sociedade... de algum lugar este dinheiro vai ter que salR... o dinheiro não vai surGIR... temos que realocar o dinheiro... essa é uma decisão como sociedade que nós temos que tomar... se vamos fazer Obras... ou se vamos deixar alguma obra para fazer depois... e vamos cuidar da BAse da sociedade... como toda a sociedades bem sucedidas fizeram... que é... CUlda da criança primeiro... CRIAse... forma-se um adulto inquisiTIVO... auTÔnomo... e Aí SIM conseguimos ter o progresso... ou então fazemos como hoje e continuamos rastejando atrás dos problemas... reagindo ao invés de agir... então essa é uma resposta que a gente tem que dar no dia CINco de outubro nas urnas... qual o nosso projeto... e eu acredito... honestamente... que o melhor projeto é cuidar das crianças na área onde... de competência exclusiva da prefeitura... que é a faixa de zero a dez...

L1: quem pergunta aGOra é o candidato Gilberto Kassab...

L3: a minha pergunta é para a candidata Soninha... Soninha... todos puderam observar que ao longo de minha gestão tive uma preocupação muito grande com a questão do meio ambiente... encontrei na cidade de São Paulo TRINta e três parques... vou encerrar essa gestão com MAis trinta e três novos parques... portanto FIZ... ao longo da minha gestão... o que foi feito ao longo de quatrocentos e cinqüenta anos da história da cidade de São Paulo... a pergunta que eu lhe faço é... quais são as suas propostas e a sua visão em relação à REcuperação da qualidade do meio ambiente da cidade de São Paulo...

L4: hum... eu imaginei que a pergunta ia ser para mim sobre esse tema ((risos))... porque você sabe que eu avalio a gestão do meio ambiente nessa administração sob o cuidado do Eduardo Jorge... uma pessoa que eu admiro muito como uma das BOas marcas dessa gesTÃO... algumas coisas tem de continuar... tem por 
exemplo um programa de aGENtes ambientais que trabalham junto com 0 programa Saúde da Família que é MUlto interessante... aliás... o programa Saúde da Família faz esse traBAlho também de... dos agentes comunitários traTArem de questões ambientais então eu acho que isso tem que ser mantido e ampliado... o programa dos córregos limpos... dos parques lineARES... os criTÉrios de... a qualificação exigida para os diretores de parques... que isso também foi um avanço agora... então muitas coisas boas vêm sendo feitas... tem uma lei minha também que foi aprovada na Câmara que obriga a prefeitura a substituir paulatinamente 0 materiAL usado internamente pela prefeitura por material reciCLAdo... então as compras de material escolar já foram feitas segundo ESSE... esse critério DEssa lei... mas ainda falta muito o que fazer prefeito... a gente anda muito pela cidade ainda e vê córregos mal-cheirosos e poluídos e com muito lixo e mato e as pessoas se queixando de RAtos e de várias outras condições ruINS... ahn:: gente precisa investir MAis nessa... nesse criTÉrio de... de... de SUStentabilidade ambiental para as compras da prefeitura... como a prefeitura adquire produtos e serviços em grandes quantidades e quanto MAis ela for exigente em relação a isso mais tem condições de enfrentar o merCAdo... e a coleta seleTIva... a gestão de re/... de resíduos em São Paulo é algo que precisa melhorar MUlto... avançou muito pouco nos últimos anos...

L3: pois é... isso é muito importante... o reconhecimento de TOdos na cidade de São Paulo... isso é... quase uma unanimidade... de que na nossa gestão avançamos muito na questão do meio ambiente... a começar do programa Cidade Limpa... que recuperou o visual da cidade... São Paulo hoje é uma cidade mais boNlta... a como/... depois a recuperação do ar da cidade... a inspeção veicular... há VINte anos nós não implantávamos... tentavam/ todos os prefeitos tentaram implantar a inspeção veicular... uma medida necessária... a criação desses trinta e três parques... já desapropriamos mais quaRENta áreas ao longo da próxima gestão faremos mais quaRENta parques na cidade de São Paulo... e teremos também... a oportunidade de... com a restrição da circulação DE:: caminhões... lá no centro da cidade... no período de durante o dia... a gente restringir e diminuir a poluição na cidade de São Paulo... QUEro dizer que... na questão dos aterros também foi fundamental a captação dos gases... que hoje são convertidos em energia... e a partir daí contribui para diminuir os efeitos do aquecimento global e a poluição na cidade de São Paulo... enfim... avançamos

L1:

[

sua tréplica...

tempo candidato...

[

L3:

muito na questão do meio ambiente...

L4: é verDAde prefeito... mas também o secretario Eduardo Jorge... por exemplo... defende o pedágio urBAno... a restrição da circulação de veículos particulares no centro da cidade... no projeto de lei que trata das políticas relativas às mudanças climáticas... pelo que foi Dlto... o senhor recuou em relação a essa quesTÃO... porque é uma questão que causa muita resistência ainda na sociedade embora ao que parece todos os candidatos estão estudando a sua implantação... a restrição de caminhões... criou problemas para a própria coleta seleTIva... porque algumas centrais de triagem não puDEram mais fazer a coleta no horário comercial... e com isso a produtividade... reduZIU éh/ diminuiu muito... e aliÁS... éh... essa 
prefeitura de várias maneiras... ou por ação ou por omissão... provocou situações muito difíceis em relação aos catadores... que às vezes são duramente reprimidos por ah... faZER a coleta... né?... de maneira manual que não é a mais indicada PRA eles MESmos... na verdade... o certo é que eles tivessem trabalhando em centrais de triAGEM muito bem organizadas e seguras então a repressão muitas vezes funcioNOU muito rapidamente mas a oferta de melhores condições de trabalho para os catadores não...

L1: o próximo a perguntar é o candidato Ivan Valente... o senhor SÓ pode perguntar... pelo sorteio... pro candidato Ciro Moura...

L2: eu esperava que o Maluf voltasse a discutir engenharia comigo hoje mas ele não topou essa parada... eu vou perguntar para o Ciro Moura então... meu colega... queria dizer o seguinte... Ciro... a Dívida pública de São Paulo consome hoje TREze por cento do orçamento... só no ano passado fora DOIS vírgula três Bllhões de reais que sangraram dos cofres públicos para pagar juros e amortizações... como é que você pretende lidar com Essa questão crucial?...

L7: Ivan... tem dívida?... pelo que eu ouvi aqui está tudo resolvido... todo mundo aqui governou e resolveu tudo... não teve rombo... ninguém ficou devendo... eu não sei porque você está preocupado com isso... ((risos na plateia)) você não tem mais problema de segurança... de saúde... tá tudo FElto... fica tranquilo... está tudo resolvido... nós temos que pa/ partir para novas ideias como eu estou propondo... é a junção do serviço público com a iniciativa privada para atender de imeDIAto a população na parte de saúde... de educação... etc.... agora essa sua preocupação da dívida... salvo que eu esteja num outro mundo... talvez no... país das maravilhas... não tem mais problema de dívida... de saúde... de segurança... todo mundo fez TUdo... aGOra... nós sabemos que não é verdade... é preciso que você que está em casa não acreDITE em Papai Noel... CHEga dessa história que todo mundo resolveu tudo... e para saber se eu estou falando a verdade ou a menTIra... olha para São Paulo... está resolvida a segurança?... está resolvida a saúde?... e a dívida que você está colocando... como é que vai pagar?... e quando se fala que a prefeitura vai pagar... você que está em casa... que pa::ga com a FALta de tudo... com a proME:.ssa que eu vou fazer... e você fica espeRANdo fazer... fica espeRANdo fazer... e quando fica pronto... a população aumentou e continua a fila aumentando... esse é o fato Ivan...

L1: candidato Ivan Valente... a sua réplica...

L2: bem... primeira coisa que eu queria dizer Ciro... é o seguinte... TOdos que estão aqui... prefeitos... atuais... ex-prefeitos... pagaram REligiosamente a dívida PÚblica... inclusive a Marta... que diz que encontrou a prefeitura arromBAda aí pelo Pitta e o Maluf... o Alckmin pagou... o Kassab paga... todos pagam... isso quer dizer o seguinte: ninguém teve COragem de enfrentar esse problema... nós vamos suspender o pagamento dos juro das dívidas... vamos au-di-tá-la e vamos diZER... entende... e vamos renegociar a dívida... e aí eu vou dizer o que é que dá pra fazer com dois vírgula três bilhões de reais... DEZ quilômetros de metrô... CEM quilômetros de corredores de ônibus... seSSENta mil CAsas populares... que TAL se nós fiz/ zerássemos as creches e aí consultássemos o povo... no QUE fazer com a dívida... PAgar os banqueiros... ou viabiLIZAR TUdo isso que TOdo mundo está reclaMANdo que não há recursos para fazer...

L7: Ivan evidentemente que eu concordo com a tua proposta de TRANSparência eh... mas quero ressaltar também o seguinte... o governo da União... que é do Pt... vai nos ajudar MUlto... e já nos ajuda cobrando esse abSURdo que você está colocando que é a pura realidade... esse recurso de juros alTíssimos... até por falta de pagamento quando do governo do Pt de dona Marta em São Paulo... nós tivemos aumentado os juros em cinquenta por cento... de seis para nove... e ela 
também não cumpriu o pagamento... que eu acho até que ela estava correta... de três bilhões... -- que na época a dívida parte de catorze para vinte dois bilhões... -então concordo com você plenamente... antes de nós resolvermos os problemas de dívida MAL... ehn... combinada... MAL gerida... as coisas escondidas... tem que ser transparentes... eu concordo com a sua transparência... mas concordo que seja dado TAMbém nome aos bois... quem é que nos ajuda... e quem só nos promete... e não nos ajuda em nada... e até nos prejudica muito...

L1: a próxima pergunta É do candidato Ciro Moura que também Só pode fazê-la ahn... ao candidato anterior... que é o senhor Ivan Valente... que é a única pessoa que está dispoNível para responder... TOdos os outros já responderam...

L7: Ivan... nós temos realmente um certo... diferenças de idéias... você se mostra... e eu já disse a você que eu respeito as sua idéias... você é estatizante... e eu sou mais privatizante no que se refere a operação das coisas... nós estamos vivendo aqui um debate meia... meio Rolando Lero... não é isso?... e... todo mundo acreditando em Papai Noel... foi assim no primeiro... a prefeita disse que não deixou rombo nenhum... o pessoal que teve o empenho cancelado não pagou conta... você vai fazer isso?...

L2: olha $0 \ldots$ o... Ciro... a primeira coisa... queria dizer o seguinte... o assunto dívida pública que nós tratamo aí... ele é um assunto muito sério... e:... têm mais assuntos sérios que ninguém trata aqui... todo mundo só promete... o que existe é o seguinte... eu faço... faço... e aconteço... depois... NÃO vai fazer... eu estou dizendo... da onde vai sair o dinheiro... então... uma dívida que é ilegal... ilegítima e imoRAL... precisa ser submetida a... à população... ela precisa ser renegociada... segundo... é preciso cobrar a Dívida ativa do município... são VINte e Olto Bllhões de reais... nós temos vinte e oito bilhões... então eu quero dizer para você o seguinte... os cinQUENta maiores devedores... possivelmente devem muito dinheiro... por que é que ninguém cobra?... possivelmente porque tem financiadores de campanha... aí atrás... os candiDAtos FOgem de questões chaves que são o seguinte... por exemplo... fazer o Iptu progressivo... quem tem mais... paga mais... jus-ti-ça so-cial... justiça fiscal para fazer justiça social... aí sim nós vamos universalizar direitos... aí sim nós vamos inverter prioridades... vamos Dlstribuir renda... e poder falar Olho no olho com a população... entende?... que nós não vamos só fazer marketagem política na televisão... nós vamos viabiliZAR aquilo que interessa a grande maioria... distribuir renda...

L1: candidato Ciro Moura...

L7: Ivan... veja só... é a grande discussão que nós temos que mosTRAR para a população... o que é FAto e o que é boato... apesar de tendo sido dito aqui que está tudo resolvido... nós tivemos no governo anterior... a saúde comPLEtamente abandonada... um ato desumano de manter durante quatro anos... seTENta mil crianças naquelas famiGEradas escolas de LAta... não preciso explicar o que aquilo significava no inverno... no verão... etc.... por uma motivação Po-lí-ti-ca... eu estou preocupado Ivan... com a realidade de São Paulo... com a diFlculdade da população de São Paulo... como você demonstra estar preocupado... que a transparência... e eu sou uma pessoa que quando prometo... cumpro... vocês nã-o vã-o ou-vir ba-le-la da minha parte... esse é o meu compromisso com São Paulo... e se eleito vou cumprir o meu mandato até o ÚLtimo dia... já SUgeri que os candidatos fizessem o mesmo... e ninguém assumiu nada até agora...

L2: candidato Ciro... primeiro eu quero dizer o seguinte... veja... educação... saúde... mo-bilidade... são di-rei-tos do cidadão e deve ser di/ dever do estado... então universalizar a educação pública... gratuita e de qualidade é obrigação... o que nós assistimos em gestões anteriores... foi a REdução dos gastos com manutenção e desenvolvimento do ensino... aqui em São Paulo... a saúde vem 
sendo privatizada... o transporte... tá entregue a SAnha de concessionárias... quando a gente fala em criar uma emPREsa municiPAL de transporte coletivo... nós tamos falando em REgular o transporte... nós tamo que fala/... falando para a população que ela TÊM diRElto ao subSídio... ela TEM diRElto à tarifa zero para cheGAR ao traBAlho e mais... ela tem direito a que o transporte tenha REgularidade conforto e etc.... é por isso que nós devemos dizer que o estado deve avançar SIM...

(( vinheta musical junto com a fala de L1))

L1: no próximo bloco... no próximo bloco... os jornalistas da Band fazem perguntas para os candiDAtos... eleições Do::is mil e oito... debate... você decide na Band... (( intervalo comercial))

(( vinheta musical junto com a fala de L1))

L1: e volTAmos ao seGUNdo encontro entre os CANdidatos à prefeitura de São Paulo... participam desse bloco os jornalistas da BANd José Paulo de Andrade e Fernando Vieira de Mello... lembrando que este debate também é transmitido ao VIvo pela BANd News Tv... pelas rádios BanDEIrantes Am e Fm... BANd News Fm e pela in-ter-net... vamos agora às regras do QUARto bloco... JORnalistas da Band perguntam aos candidatos em ordem já sorTEAda... o jornalista escolhe OUtro candidato para comenTAR... resposta de UM minuto e meio... comentário e RÉplica de um minuto CAda... o jornalista José Paulo de Andrade pergunta para o CANdidato Paulo Maluf e escolhe quem vai comentar...

L10: boa noite a todos os participantes $0:$ : debate transcorre muito bem... com os problemas sendo abordados... e um dos problemas mais sérios da cidade candidato Paulo Maluf... é a saúde pública... que envolve as três esferas do governo... o senhor inSISte que vai trazer de volta o Pas... e nós nos lembramos que quando o Pas foi implantado o senhor teve um problema seRísSImo de não receber verbas do Sus... além DI::sso... houve um boicote NÃO-declarado ao PAS aqui em São Paulo por parte de hospitais públicos o senhor deve ter tomado conhecimento disso... o senhor vai de NOvo arriscar nessa roleta?...

\section{[ \\ L9: \\ vê \\ [ \\ L1: \\ quem comenta... José Paulo?...}

L10: comentário de Geraldo Alckmin...

L9: veja... José Paulo de Andrade... o PAS foi avaliado quando eu saí da prefeitura... pelo jornal $O$ Estado de São Paulo... com noVENta por cento de aprovação...

pela

Folha de São Paulo... oiTENta por cento de aprovação... e pelo lbope... noVENta e dois por cento de aprovação... agora... por que que na minha gestão ela foi aprovada... e a... saúde pública HOje tem problemas em todos os se/ os setores... veja o doENte não é NEM federal... NEM estadual... NEM municipal... o doente é brasileiro... e quando existe um problema jurídico do Sus com qualquer estado brasileiro... ESSE problema jurídico não pode fazer com que se penalize a população... ou seja a população TEM direito... e olha... no meu tempo tinha carteiRINHA... com a carteirinha ele podia ser mediCAdo num hospital público... num hospital particular... e as coisas funcionavam... e $\mathbf{O}$ que é HOje a descentralização da saúde pública... quando POR exemplo o governo do estado e a prefeitura dá e dá muito bem... dá por exemplo administração para o hospital 
Alberto Einstein... que é um GRANde hospital... para a Santa Marcelina... que é um grande hospital... NAda mais é do que o Pas... É a administração descentralizada... com auditoria... para que os remédios possam ser comprados por preço barato... veja... ainda a pouco teve lá um desvio... no interior... de dinheiro... em Marília... não se pode culpar o Governo do Estado... as pessoas é que tem que pagar as pessoas físicas... no meu tempo funcionou porque EU tenho gestão... e VAl funcionar comigo...

L1: $\quad$ candidato Alckmin... o seu comentário...

L8: eu entendo que o caminho é diferente... éh... o Sistema Único de Saúde... ele tem o deVER de atender BEM a população... hoje é um dos MAIOres sofrimentos... eu tenho impressão que hoje o maior PROblema de São Paulo para a população que não tem convênio... é a saúde... qual é a nossa proposta?... reforçar o programa de Saúde da Família... contratar MIL e quinHENtos médicos porque não adiante fazer PRÉdio se não tem médico... ahn... melhorar o atendimento primário... que são as Ubss... construir dez centros de ESpecialidade com ALta resolução para acabar com estas filas eNORmes para imagem... para tomografia... para ultrassonografia... de outro lado... DEZ centros de referência dos idosos... porque a população está ficando mais VElha... e precisa ter políticas públicas pros idosos... e hospitais onde a população precisa... não tem cama... nós vamos fazer um hospital em Parelheiros na zona sul... Brasilândia na zona norte... e na zona leste na região de São Mateus e Iguatemi... como governador fiz NO::ve hospitais NOvos... funcionando...

L1: RÉplica do senhor Paulo Maluf...

L9: Alckmin... você precisa não confundir a sua administração com a do Mário Covas... quem fez os hospitais a maioria deles foi Mário Covas quando você era vice-governador... agora eu peço à você que não acredite no que eu estou falando... eu aGOra... nesta campanha eleitoral... fui no lesp... lá no Hospital do Servidor Público... na rua Pedro de Toledo... que é um hospital do Governo do Estado... e uma senhora lá me pegou e disse... Seu Maluf eu preciso duma consulta... era no mês de junho... TÁ marcada PRA dezembro... em dezembro ou eu sarei e não preciso da consulta... ou eu moRRI e não preciso da consulta... quero diZER que os hospitais do EsTAdo... quando você foi governador... deixaram muito a desejar... porque hospital é gesTÃO... não é só construlR... construir é o corpo... precisa da alma... precisa do MÉdico... precisa do reMÉdio... precisa da tecnologia... precisa dos aparelhos... e ISto... a população de São Paulo SAbe... quando fui governador e quando fui prefeito... a SAÚde funcionou e funcionou BEM...

L1: agora o jornalista Fernando Vieira de Mello PERgunta para o CANdidato Renato Reichmann...

L11: boa noite a todos os candidatos... o comentário é do candidato Ciro Moura... candidato Reichmann verificando o site do Tribunal Regional Eleitoral no item prestação de contas... a gente verifica que o senhor tem uma reCElta declarada de selS mil oitocentos e setenta e cinco reais para esta campanha majoritária... o senhor está fazendo campanha de rádio e de televisão... como é que o senhor vai fazer para pagar as contas da campanha...

L5: bom... éh:: quem tá pagando o programa... éh... gratuito como é permitido por lei... é o partido... com o fundo partidário... quer dizer as gravações de estúdio... esses seis mil e oitocentos se referem a basicamente de novo pela legislação eleitoral... a gente tem que decla/ declarar o veículo que utiliza... e inclusive o 
comitê que utiliza... que no caso é também parte da minha casa... então na verdade são es/ essas despesas que tav/... de resto são pequenas despesas... tipo vale transporte e um pouco de gasolina aqui... um sanduíche ali... e campanha municipal é muito interessante nesse sentido... é uma campanha muito territorial muito presencial... é uma campanha que não exige uma grande logística... como uma campanha estadual ou federal... ela não exige deslocar uma grande equipe... eu FElizmente... apesar de nós termos uma equipe peQUEna... no núcleo do partido... eu conto muito com apoio DOS candidatos a vereança... que coNHEcem a sua comunidade e têm sido ex-ter-ma-men-te úteis e luTANdo junto... visitando as comunidades... discuTINdo os problemas... então... BAsicamente... NO município dá pra fazer campanha com muito pouco dinheiro... às vezes eu vejo volumes muito altos e me pergunto porque que se gasta tanto dinheiro se dá para fazer com muito menos...

L1: seu comentário... candidato Ciro Gomes... oh... perdão... Ciro Moura...

L7: esse moço depois que copiou o meu nome... ((risos)) ele nasceu depois de mim... gostou do nome e copiou... mas realmente as pessoas confundem muito Boris... eu não tenho nenhum problema em relação a isso...

L1: candidato... eu lhe peço desculpas...

L7: não precisa não... ô:: Renato... vou falar uma coisa pra você... nós temos... eu entendi a sua situação... ahn:.... nós temos um partido pequeno... com um fundo partidário muito pequeno e não temos alternativas... e afora isso... com esses recursos que você está declarando... com muitos detalhes etc. e tal... são recursos que você consegue realmente dizer de onde vieram... tá certo?... eu quero... e discordo de você... pra ser eleito prefeito de São Paulo tem que gastar MUlto dinheiro... é que você está fazendo programa SIMples... e... olhe os outros programas... então nós temos que falar para o povo de São Paulo a realidade... não se elege prefeito de São Paulo com pouco dinheiro...

L1: candidato Reichmann...

L5: eu acho que... já que estamos cuidando dessa parte de financiamento de campanha... eu acho que/ financiamento DEve continuar na iniciativa privada porque eu não quero que o EsTAdo de novo me diga que ele sabe cuidar melhor do meu dinheiro para fazer campanha do que eu... mas eu acho que tem que haver limite... alguém que dá duzentos... quinhentos ou mil... ou um milhão para uma campanha quer alguma coisa em troca... OU no MÍnimo um ESpaço para em algum momento pedir alguma coisa e ser recusado com dificuldade... eu acho que deve ser modelo americano... outros modelos funcionam... no sentido de que... É financiamento privado mas existe um limite... pode falar um número... dez mil reais para empresa... dois mil reais para pessoa física e uma campanha institucional... como

nos

Estados Unidos nós estamos vendo agora do Barack Obama... doações de dez... vinte... cinquenta... e nesse sentido aí sim... aí nos temos candidatos inTEIramente descomprometidos e dá pra fazer campanhas aTÉ basTANte eh... volumosas... porque campanha municipal dá para fazer barato... estadual... federal não dá porque o deslocamento... a logística... é muito complexa...

L1: agora o jornalista José Paulo de Andrade pergunta para o candidato Ivan Valente...

L10: foi dito aqui... candidato Ivan Valente... que o senhor é estatizante... então a minha pergunta... com o comentário de Soninha Francine... o senhor traria de volta a Cmtc ao transporte coletivo de São Paulo?...

L2: bom em primeiro lugar eu quero dizer o seguinte... ahn... o fato de você ter uma empresa como a Cmtc que foi... corroída por dentro por governos corruptos e depois foi desmontada não quer dizer que uma empresa PÚblica não possa ser 
FIScalizada... controlada e ser eficiente... então eu entendo que é necessário criar uma empresa Pública de transportes... e isso significa éh:.... ter controle do sistema... significa que nós NÃO vamos ficar SUbordinados ao lucro fácil das empresas... ao capitalismo sem RISco das concessioNÁrias... e é possível sim REgular e com um contro::le social... com participação popular... com TRANparência... ter empresas públicas que sirvam ao interesse público... essa lógica que tudo o que é privado é eficiente e o que é estatal é ineficiente... é corrupto... ela é INcorreta... ela foi produzida por uma uma lógica libeRAL entende?... que rigorosamente não atende aos anseios de universalização de direitos e distribuição de renda... e MAis do que isto... não querem que a população participe... porque na iniciativa privada não tem lanterna... não tem LUZ... para se verificar o que está acontecendo... então no setor público... é possível ter sim essa empresa e ela ser Útil e eficiente para a população...

L1: seu comentário... candidata Soninha Francine...

L4: bom eu lamentei muito depois da gestão da da Luiza Erundina... quando foi feita/ a DÊS-municipalização do sistema de transporte... a privatização... numa processo aliás bastante discutido... bastante contestado na época... o fato é que como usuária do transporte coletivo na época... eu me lembro do quanto melhoROU o serviço... o TEMpo que eu levava pra ir pra faculdade quando a Erundina era prefeita e depois veio a desmunicipalização... e e um processo alNda... ah:.... candidato... que inda DElxa... tem um lastro ainda de processos trabalhistas... uma SÉrie de problemas DESde a época da Cmtc... que ainda prejudicam de alguma maneira as operações da Sptrans... agora não seria viável estatiZAR novamente o sistema de transporte... e tem algumas vantagens na gestão privada na agilidade por exemplo para a resolução de problemas mecânicos dos veículos... não tem como a máquina estatal ser tão ágil nessas questões... mas eu estou de acordo que tem que ter o controle do EsTAdo... a prefeiTUra exercer o seu poder de controle... de monitoramento... de exigências e controle social também inclusive com o conselho municipal de transporte...

L2: éh:.... a pergunta que foi feita Soninha... não foi se nós vamos estatiZAR o transporte... mas se eu criaria uma empresa muniClpal de transporte... uma empresa PÚblica... e eu digo pra você... que isso é essencial... sem a qual você não fiscaliza... NÃO controla... NÃO COMpara... e não tem condições de verificar qual é o lucro das empresas... qual é a eficiência das empresas inclusive... esse é um dos grandes erros... e é um CRIme o que foi feito no Brasil em matéria de privatização... isso vem do plano fedeRAL inclusive... por exemplo... privatizar o sistema Telebrás... e acaBAR com a Embratel... foi crimiNOso... hoje você precisa... pra botar o presidente da republica no ar... falar com a Tel MEX lá no México... aqui é a mesma coisa... não há receio de se criar uma empresa pública municiPAL e mesmo que ela venha a ser uma estaTAL depois... se tiver controle popuLAR... isso será eficiENTE e melhor para a população...

L1: agora o jornalista Fernando Viera de Mello pergunta ao candidato Gilberto Kassab...

L11: comentário da candidata Marta Suplicy... candidato Gilberto Kassab... a justiça federal proibiu que a prefeitura de São... São Paulo contrate entidades PRIvadas para a administração de hospitais públicos e outras unidades de saúde na cidade de São Paulo... o senhor acha que São Paulo pode prescinDIR dessas entidades privadas e pode aplicar melhor esses recursos?...

L3: primeiramente eu queria deixar claro que não é qualquer entidade privada que faz a parceria com São Paulo... são entidades iDÔneas... nós estamos falando de Usp... UniFESP... Santa CAsa... Irmãs MarceLINAS... Albert Enstein... SírioLibanês... IrMÃS de Santa Catarina... que prestam exceLENte serviços na cidade 
de São Paulo... em segundo lugar... essa questão está amparada juridicamente por uma liminar no Supremo Tribunal Federal... e diferentemente de outros momentos da vida pública de São Paulo... HOje existe um entrosamento perfeito entre os nossos servidores e essas entidades... o serviço é de excelência... GRAças a essas parcerias implantamos na cidade de São Paulo cento e quinze Amas... DOis novos hospitais... contratamos TRÊS mil MÉdicos... e fizemos um avanço muito grande na qualidade do serviço de saúde prestado a SEte milhões e meio de usuários... hoje... segundo pesquisas... TRINta por cento da população entendem que o nosso serviço é Ótimo ou bom... setenta por cento ainda não... mas o importante é lembrarmos que no iNício de nossa gestão... ZEro... ninguém achava que o serviço prestava... hoje avançamos e vamos continuar avançando... de-fen-do este modelo... o Governo do Estado já com o nosso querido e saudoso governador Mário Covas implantou isso em São Paulo e o próprio governo federal já muDOU o conceito... sua visão com relação a esse modelo... e também pensa em implantá-lo... portanto... confio em nossa justiça... estamos amparados por uma liminar... e para a cidade de São Paulo E MÜlto importante esse modelo de parcerias porque melhorou... melhorou muito a qualidade do atendimento da saúde pública na cidade de São Paulo...

L1: comenta a candidata Marta Suplicy...

L6: em relação às $A O /$ às OASs nós vamos manter com maior fiscalização... controle... porque hoje essa é a grande queixa e reclamação... agora a descrição do prefeito... éh... Kassab é é... nós temos a sensação de que nós estamos vivendo num mar de fantasia porque quem é POvo... quem vai/ usa serviço PÚblico... quem quer marcar um exame de especialista na cidade... como uma senhora que me falou ontem... que tava marcado para jaNEIro de dois mil e dez o exame dela... ou outro que demorou dez meses prum exame de orto/ de especialista em ortopeDIA... sabe que isso é uma ilha de fantasia... nós vamos realmente dá um salto na na questão da saúde... fazendo nas subprefeituras as poliCLÍnicas... que vão... FINALmente nessa cidade... o indivíduo poder marcar o seu exame de especialidade... o sua consulta lab/ a sua consulta... tudo hoje que ele não tem acesso... também nós sabemos que as Amas elas ajudam... mas elas NÃO resolvem... elas não tem resolutiviDADE e nós vamos melhorá-las...

L3: a Marta precisa saber que as policlínicas já existem... hoje já são CINco Amas para especialistas na cidade de São Paulo... serão trinta... Amas voltadas para as consultas... e também evidentemente que são todos informados de que OUtros programas importantes acontecem na cidade de São Paulo que melhoraram o sistema público... no atendimento da saúde... MÃE Paulistana... ReMÉdio em Casa... a INformatização da distribuição de remédios... a central de medicamentos... o que eu posso dizer é que eu conheço hoje a cidade... a cidade real... e infelizmente na gestão anterior Marta... na sua gestão... não foi aprovada por isso você não foi reeleita... principalmente porque você foi muito mal na saúde... e hoje... é o carro-chefe da nossa administração... saúde e educação... enquanto nós não tivermos uma saÚde e uma educação de excelÊNcia... igual à particular na cidade de São Paulo... eu como prefeito não sossegarei... porque não é justo socialmente... as pessoas pagam impostos e a prioridade do poder público... antes de mais nada... é dar uma saúde de qualidade e dar um enSIno público de qualidade...

L1: agora o jornalista Fernando Vieira de Mello pergunta para o candidato Ciro Mou-ra...

L11: com o comentário do candidato Renato Reichmann... eu queria que o candidato Ciro Moura comentasse a TÃO sonhada reforma política no Brasil... que pretende... entre outros objetivos... é concenTRAR o número de partidos... DAR 
uma identiDAde... dar uma ideologia mais identificada para os eleitores a essas siglas... e acaBAR com esta SOpa de letrinhas que SÓ confunde todo ano a cabeça do eleitor...

L7: Fernando essa é a sua opinião... respeito e não concordo... se você estiver fazendo alguma referência ao meu partido eu quero dizer a você que nós somos um dos três partidos que já tivemos o maior... que elegemos o presidente da república... elegemos DOis... então eu não tenho nada que ver com essa história que você está falando... o que acontece é que nós temos um sistema eleitoral SEM isonomia... eu estou indo ao meu programa com um minuto de televisão... outros candidatos com dois... três... cinco... seis... nove... e você quer uma disputa equilibrada e vem puxar o assunto que... atrás da sua pergunta é querer saber se eu acho que os partidos devem ser extintos... eu acho SIM que os partidos tem que luTAR para mostrar a sua identiDAde... nós temos ideias... nós temos uma história... nós temos VINte e CINco anos... em mil novecentos e noventa... nós elegemos QUArenta e TRÊS deputados federais... quase dez por cento da Câmara... e eu n/ não aceito essa conversa... deixa o POvo decidir... nós temos a MAnia de fazer o papel de pai...a imprensa dando PALpite... invés de ficar na sua Área... deixa... a parte eleitoral... que seja demoCRÁtica... não esta brincadeira... aí me perguntam... como é que você consegue explicar a sua idéia?... eu tento... talvez eu tenha alguma capacidade... eu acho que nós temos que dar liberdade SIM... de deciSÃO... porque não há ninGUÉM que hoje é GRANde e que não foi peQUEno... nós fomos peQUEnos... fomos GRANdes... volTAmos a ser peQUEnos... e não tenha DÚvida... continuaremos e seremos grande...

L1: seu comentário... candidato Renato Reichmann...

L5: eu acho como em toda a natureza... a... o crescimento está na diver/ diversidade... quando mais diversidade tiver... é o sal da terra... agora quanto à sopa de letrinhas... pode ser... mas a/ a receita da nossa sopa é a mesma desde MIL noveCENtos e oiTENta e QUAtro... por vinte e quatro anos... agora... é P-MN... Partido da Mobilização Nacional... tem muito pouco partido que não mudou $A$ receita da sopa de letrinhas... e eu não sei se CENtralizar em um... dois... três... ou cinco partidos vai fazer diferença porque tem muito partido aí grande... inclusive... que é rachado em cinco ou seis facções... e a gente lê TOdo o dia no jornal... então não era melhor que essas cinco ou seis facções invés de ficarem brigando... porque isso não é ideologia... se tem uma ou duas sim... cinco ou seis facções não é ideologia... éh... porque TÁ... tem muita gente no mesmo lugar sem caBER... tendo que ir para outro lugar... então não é melhor mesmo ter OUtras siglas e uma maior variedade ideoLógica?... num mundo de cada vez de mais diversidade?...

L1: candidato Ciro Moura...

L7: ô Renato... você falou em sopra/ de letrinha... quem é aqui que não tem letrinha na sua coligação?... será que é letrinha?... muitas vezes a vida depende de uma letrinha... e na medida em que ela continua... então é... olha... eu acho que cada um tem que tratar da sua coisa... nós tínhamos que na verdade discuTIR como É essa democracia brasileira que faz do deputado federal... e veja que nós elegemos três... uma legislação malDOsa que permitia que o deputado abandonasse o partido... depois de USÁ-lo... então vamos dicutir SIM... uma democraCIA que nos dê CHANce... àqueles que ainda nem cresCERam... qu/ cresçam... e que nós... que já fomos GRANdes... o maior poder deste país que não escola que não ensina o que é isso... nós já FOmos e não tenho DÚvida... nós voltaREmos a cresCER... O nosso caminho é ASCENder... é a minha opiniÃO e eu não aceito restriÇÃO à democraCIA e à liberdade de expressão... 
L1: agora o jornalista José Paulo de Andrade pergunta para a candidata MArta Suplicy...

L10: me chamou a atenÇÃO... quan::do... a candidata Marta Suplicy se referiu ao dinheiro em CAlxa que a prefeitura de São Paulo teria hoje... QUAtro BIlhões de reais... a minha pergunta é:: sobre isso... a que a senhora atribui:: e esses números saíram de onde?... com o comentário claro... do prefeito Gilberto Kassab...

L6: esses números saíram da Câmara... estão à disposição e os vereadores podem se informar quem quiser saber... agora eu atriBUO... essa incapacidade de gastar o dinheiro da cidade... em coisas que a cidade está realmente precisando... a uma incapacidade de PLAnejamento... porque quem deixa no primeiro ano... dois milhõ/ bilhões e MEio de gestão... né?... em superávit no BANco... para os banqueiros estarem ganhando dinheiro invés de fazer CREche... que a cidade neceSSIta... reMÉdio em CAsa... que a porção de pessoa que re/ recebem remédio em casa ao contrário do que aparece na televisão é deSSE tamanho... no outro ano deixa mais três bilhões e pouco... e agora está deixando mais quatro quatro bilhões no banco... realmente não tem uma capacidade de planejar... demoRAram MUlto pra começar as obras dos Ceus podia ter sidos iniciados todos no dia seguinte da gestão... não iniciARAM... ficaram lá discutindo se começava ou não... porque eram CONtra fazer os Ceus... depois a população fez preSSÃO... e aí tiveram que construir os Ceus... então agora tem que entregar vinte e quatro Ceus... mas até agora só fizeram tre/ é treze Ceus... gastaram... ao contrário do que a propaganda enganosa diz... são Ceus MAis caros e com muito menos infra-estrutura... o teatro tem metade dos luGAres... a piscina é meNOR... a área construída também é meNOR... então é uma capac/ incapacidade DE gastar o recurso... corredores na cidade... que nós fizemos cem QUILÔmetros... o PSDB-Demo fez... éh:: sete quilômetros... não sabem gastar... não sabem planejar...

L1: comentário do candidato Gilberto Kassab...

L3: olha... José Paulo... tomara que a Marta não ganhe a eleição... senão ela vai quebrar de novo a prefeitura... porque aonde ela vai... se falta uma creche... ela diz... olha o Kassab tem recursos na prefeitura para fazer a creche... olha... mas o Kassab tem recurso para fazer o hospital... na verdade... todos sabem... um orçamento de vinte e dois bilhões... um orçamento que teve as receitas aumentadas porque nós fomos trazer de volta as empresas que soneGAvam tributos... estavam fora de São Paulo não pagando tributos e com isso aumentou a receita da cidade de São Paulo... hoje nós temos que ter dinheiro em caixa para pagar conta... Marta... nós temos contas para pagar... empenhos que quando liquidados temos que pagar... a cidade de São Paulo está construindo duzentas e dezoito escolas... fez dois hospitais... pavimentamos como nunca foi pavimentamo/ como nunca foi pavimentado em São Paulo... recapeAMOS mais de MIL quiLÔmetros lineares... esse recurso em caixa é para paGAR... porque senão... quando o futuro prefeito -- eu espero que seja eu... se contar com a confiança do eleitor -- tiver assumindo... vai ter fila de credor de novo... precisa ter dinheiro em caixa... Marta... para pagar CONta...

L6: olha... vam/ por as coisas claras aí porque... eh... a mentira falada repetidas vezes... vai acabando soando como verdade... então nós sabemos aqui que fica repetindo... repetindo... repetindo... e eu vou dizer uma das inverdades que 0 candidato tem falado... que as escolas de lata foram na minha gestão... não foram... as escolas de LAta foram construídas TOdas na gestão do Pitta na qual GilBERTO KaSSAB era o secreTÁrio do planejamento... na minha gestão eu tive a capacidade que eles deviam ter Tldo... de CONversar com $0 . . .0$ o... os o 
Ministério Público... para que a/ as escolas fossem substituídas nos lugares de mei/ de meio ambiente por alvenaria... três anos de conversa para convencê-los... convenCEmos... começamos a substituiÇÃO... deixamos todas contratadas e já no meio do caminho... tanto É que dep/ ele pôde inaugurar a primeira depois de dois meses... se eu tiv/ não tivesse feito... não teria inaugurado... aliás como a maior parte das coisas dessa gesTÃO foram iniciadas no nosso governo... e isso (é porque) quer ser apropriar de tudo...

L1: senhor Kassab...

L3: la/... a candidata

L1:<smiles>[TlH]</smiles>

Kassab... o senhor Kassab me pergunta alguma coisa... e eu pergunto a ele o que ele me pergunta...

L3: éh::... ela disse que as afirmações são mentirosas

L1: não... não... não... então

L3:<smiles>[TlH]</smiles>

L1:

isso é um direito de resPOSta... que

vai ser avaLIAdo... e... no... no intervalo do bloco... no próximo bloco... a nossa comissão de juristas... que está julgando... até o jinal/ até o final deste bloco nós responderemos se o senhor tem di-REI-to ou NÃO à esse diRElto de resPOSta... pergunta agora do jornalista José Paulo de Andrade para a candidata Soninha Francine...

L10: me parece que:....... é unânime a opinião... que para melhorar o transporte público de São Paulo é necessário implantar corredores então eu gostaria de saber:.:..... qual é a idéia de Soninha Francine em relação aos corredores... com o comentário de Ivan Valente... que tamBÉM vai poder dizer qual é a sua ideia para o corredor de ônibus... pra/ pro trânsito fluir e para a população ser mais bem atendida...

L4: muito bem já existem em planejamento vários novos corredores... a partir de estudos TÉCnicos... de deMAN::da... de viabiliDAde... o plano diretor estratégico já prevê PRAzos para a remodelação dos corredores... e na verdade a a gestão da Marta que investiu muito nisso não FEZ:: cem quilômetros de corredores... corredores começaram a ser feitos desde a gestão do Covas... do Jânio... da Erundina... ela de fato criou alguns novos e REmodelou alguns que passaram a funcionar muito melhor... mas não adianta só fazer mais corredores... o o que É interessante... porque o transporte coletivo tem de ter prioridade sobre o transporte individual... mas não adiante se eles forem mal administrados... se houver veículos em exCEsso no corredor de ônibus... o corredor vira um congestionamento... como JÁ já aconteceu... já se presenciou várias vezes por exemplo no corredor da M'Boi Mirim... então o sistema tem que ser bem-administrado... às vezes é muito mais interessante haver MEnos veículos e veículos maiores e mais espaçosos que percorram efetivamente o trajeto DO correDOR... funçando/ funcionando como a gente chama como uma linha TRONco... ou como um meTRÔ sobre ROdas... né?... então um veículo MAis espaçoso... éh... tem intervalos mais regulares... circula melhor... e o corredor aí sim ele é alimenTAdo por OUtros veículos menores... por outros ônibus e microônibus... ah:.... para que as pessoas possam fazer a baldeaÇÃO usando o bilhete único sem pagar nada pelo segundo embarque... MEŞmo que não seja no corredor de ônibus... mesmo numa avenida que não tenha essa pista exclusiva... a GEStão de todas as linhas do sistema de transporte tem que ser melhor do que é hoje... não adianta só colocar mais 
veículos na rua ou separar a circulação de uns e de outros se não for bem administrado...

L2: ((limpa a garganta)) bem primeiro eu queria colocar que:.... um terço da população de São Paulo anda a pé... então... quando nós subsidiarmos pra valer o transporte nós vamos precisar de mais transporte coletivo... então... hoje tem... éh::... oito/ oito milhões de pessoas que andam... vão ter MAis gente andando... e é preciso que o ônibus FLUa... precisa de corredor exclusivo... inclusive para isso... mas ele não precisa de corredor exclusivo sozinho... porque hoje... as empresas... elas lutam para enTRAR no corredor... e só é possível... se criar uma empresa MUnicipal... que seja res-pon-SÁVEL pela pelo doMínio dos corredores TRONco alimentadores... só é possível com isso... quer dizer o estado inter/ intervêem... e diz o seguinte... além do transporte subsiDIAdo Soninha... sem nenhum bom-moCISMO... eu acho que nós temos que atacar o problema do transporte... de FUNdo... enfrentando os GRANdes interesses da cidade... eu acho que E ISSO QUE preClsa ser FElto... senão vai ser

L1:

tempo... tempo candidato

[

L2: $\quad$ senão vai ser um festival de propostinhas...

L1: réplica da candidata Soninha Francine...

L4: tem direito à réplica?... eu não lembrava...((risos)) achei que era só resposta e comentário

L1:

não... tem

[

L4: ah... que ótimo... muito obrigada... éh:.... é como disse o candidato... tem de haver um esforço de gestão da própria prefeitura... a prefeitura é quem detém as linhas de ônibus... as empresas... prefeitura é DOna das linhas de ônibus... as empresas são concessionárias e devem explorar as linhas... então a prefeitura tem de exercer mesmo o seu poder regulamentador... para fazer com que a operação dos corredores... a circulação pelas avenidas seja melhor do que é... e como eu já disse várias vezes... é é preciso criAR algumas novas linhas... não adianta... é... investir só no sistema ah... RaDlal das linhas que se cruzam no centro... que são dirigidas ao centro... as ligações entre as regiÕES... entre os bairros ah:.... da cidade tem de ser melhoradas... hoje se você vai de um bairro no noroeste da cidade pro norte... tem que dirigir para a Marginal Tietê... sobrecarregar ali 0 sistema viário... o sistema de transporte... pra depois fazer uma outra viagem de volta... então a prefeitura tem de fato de exercer essa sua capacidade de gerenciamento pra ver onde tem ônibus em excesso e onde tem lacunas... e onde o serviço precisa ser mais bem administrado...

L1: eu queria informar aGOra ao senhor Kassab que a comissão julgou improceDENte o seu pedido de resposta... muito obrigado pela compreensão... o jornalista Fernando Vieira de Mello pergunta para o candidato Geraldo Alckmin e o único a comentar é o senhor Paulo Maluf Fernando...

L11: candidato Geraldo Alckmin... o senhor tem dito que VEREador NÃO vai mandar na sub-prefeitura... o senhor acha que é possível governar São Paulo com apoio da Câmara Municipal SEM esse tipo de acordo?... 
L8: éh... eu entendo que houve um desvirtuamento... éh:.... Fernando... da descentralização... a descentralização ela é coRRETA... São Paulo é uma cidade pluRAL... então a criação de sub-prefeituras ela me parece ehn... extremamente importante para colocar o governo mais perto da população... e eu pretendo cumprir a lei orgânica municipal... colocando... ahn:.... NAS sub-prefeituras 0 conselho de representantes... agora não é para haver um loteaMENto de natureza poLÍtica... e os poderes devem ser INdependentes... não deve haver uma mistura entre atividades de vereador e as questões do executivo... eu pretendo nomear os sub-prefeitos... pessoas vinculadas à região... com caráter profissional... com caráter técnico... todo RESpeito ao poder legislativo mas sem neNHUma interferência... aliás fui a à Berlim... fui à Hamburgo na Alemanha pela fundação Konrad Adenauer... estudar a descentralização... e nós vamos fortalecer MUlto esse trabalho... um dos GRANdes problemas hoje de São Paulo... e está se discutindo muito aqui trânsito e transporte... é o problema do Plano Diretor EstraTÉgico e da lei do uso do solo... porque a região mais central está ficando vaZIA... o PARI foi o distrito que MAis PERdeu população... crescimento negativo... nós vamos inverter... trazer as pessoas de volta para o centro... para morar no centro e criar novos pólos auto-sustentáveis nas regiões mais distantes... L1: comentário do candidato Paulo Maluf...

L9: concorDAmos... em TERmos com a proposta do candidato Alckmin... não se pode politiZAR as administrações regionais... não se pode entregar pura e simplesmente para os vereadores... o comando de todas as administrações regionais NÃO... as administrações regio/ regionais... as sub-prefeituras... que hoje infelizmente viraram cabide de emPREgo... a lei de dona Marta Suplicy ela criou as sub-prefeituras com milhares e milhares de empregos... eu gostaria de dizer que isso tem que ser enxuGAdo... e tem que ser pessoas da própria coletividade IoCAL... quem é da Lapa fica com a LApa... quem é de Itaquera fica com a Ita/ com a Itaquera... quem é de Santo AMAro com a de Santo AMAro... Capela do Socorro Capela do Socorro... pessoas da coletividade... ligada à região... ao Lyons... ao Rotary... às associações de classe ou seja... TEM que haVER nas subprefeiTUras de São Paulo um verdadeiro REmanejamento DE gesTÃO...

L8: olha... eu quero... eu quero eh:.... colocar... primeiro fazer um um reparo aqui ao ao candidato Maluf... quando eu falei que eu fiz NOve hospitais... entreguei nove hospitais foi no meu governo... se incluir o governo Mário Covas do qual eu me honro de ter sido vice... foram deZOlto hospitais no estado e NÃO estou incluindo o Instituto do Câncer... que eu deixei praticamente PRONto e que já está funcionando inaugurado pelo governador éh... José Serra... em relação ao tema... da questão Câmara vereadores e a prefeitura... nós vamos... éh... melhorar a gesTÃO... vamos ter um trabalho éh... de boa parceria com a Câmara Municipal mas NÃO permitindo que sub-prefeitura vire co/vire comitê de vereadores... isso é inadmissível... éh... não permitindo caBldes de empregos também... privilegiando funcionário... vou valorizar o funcionário... caRREIra... pagar os precatórios... profissionalismo... GEStão... e DEScentralizar... levar PÓlos para regiões mais distantes... e as pessoas voltarem a morar no centro de São Paulo...

(( vinheta musical junto com a fala de L1))

L1: no próximo bloco uma nova rodada de perguntas ENtre os candidatos... fique com a gente... eleições dois mil e oito... debate... você decide na Band...

(( intervalo comercial))

(( vinheta musical junto com a fala de L1))

L1: e voltamos com o deBAte entre os CANdidatos à prefeiTUra de SÃO Paulo que também é transmitido ao vivo pela inTERnet... pela BANd News Tv e pelas rádios BANdeirantes $\mathrm{Am}$ e $\mathrm{Fm}$ e BANd News Fm... vamos as regras deste 
QUARto bloco... CANdidato pergunta para CANdidato... a ordem aqui se inVERte em relação ao segundo bloco... pergunta de TRINta segundos... resposta de UM minuto e MEIO... RÉplica e TRÉplica de um minuto CAda... quem pergunta é o candidato Clro Moura...

L7: eu quero perguntar à candidata... à ex-prefeita Marta Suplicy... em dois mil eu fui candidato como a senhora foi... a senhora fez uma série de promessas e não cumpriu... principalmente naquilo que se referiu à saúde... na eleição de dois mil e quatro a senhora volta a prometer e a população não acreditou nas suas promessas... a senhora per/ perdeu a eleição... a senhora continua prometendo e veja que no caso do metrô não tem UM tostão no orçamento... a senhora acha que essa técnica vai valer nesta eleição?... da promessa que não será cumprida?...

L6: ao contrário candidato... eu diria que eu cumpri $\mathrm{m} /$ todas as promessas e mais algumas que eu não tinha prometido... porque em relação ao transporte que era a área MAis difícil... eu promeTI chegar no bilhete Único... e se NÃO tivesse TIdo a coragem de enfrentar aquela MÁfia.... de enfrentar os clandesTInos... e de persisTIR na busca do que eu sabia que a população queria... eu não teria chegado no bilhete único... não tinha prometido o Ceu... mas eu FIZ os Ceus... inoVEl... criEl... ouSEl... tive o Psdb... o Dem... contra a criação dos Ceus... contra a instalação dos CEUs e em relação ao orçamento para o meTRÔ... hoje a prefeitura de SÃO Paulo governa com DEZ BIlhões a malS e não é pelo motivo que Kassab DIsse... porque foram grandes fiscalizadores e tudo o mais... NÃO... é porque o governo Lula melhorou o orçamento de TOdas as prefeituras... quando São Paulo vive uma recessão... aqui é o pior lugar... onde tem o maior desemprego e diminui a receita... quando o Brasil vai BEM... e que hoje o Brasil vai bem como há MUltas e muitas décadas não IA BEM... São Paulo aumenta o seu orçamento... então DEZ bilhões a mais... eu pergunto para você que está me escutando em casa... o que foi feito com dez bilhões a MAis?... nós com DEZ bilhões a menos fizemos tan/ TÃO mais do que eles com dez bilhões... nós vamos ter dinheiro para por no meTRÔ:.... e nós vamos ter a parceria com o Governo FedeRAL que está junto conosco... aprovou o PLAno para a expansão do meTRÔ... e nós vamos fazer tudo porque sabemos e temos capacidade de planejar e cumprir...

L1: eu pediria a gentileza que a distinta plaTEla não se manifestasse... por gentileza... candidato CIro Moura...

L7: bom eu insisto que na... eleição de dois mil a senhora disse que ia fazer uma revolução na saúde... e fez mesmo... ela ficou muito pior... depois veio a senhora na eleição de dois mil e quatro... no vácuo favorável do Ceu que é uma palavra bonita... o que é preciso resultado... a senhora nos prometeu o Ceu saúde... que era uma maquete de uma policlínica e que o povo não acreditou... e até reagiu quando eu perguntei se ele acreditava em Papai Noel... agora a senhora volta e info/ a prometer que vai investir no meTRÔ... que o presidente LUla vai ajuDAR quando não tem UM TOSTÃO no orçaMENTO... você que está em casa... VOCÊ acredita em Papai Noel?... vai começar TUdo de novo?... é preciso um pouco de seriedade... vamos fazer como eu faço... eu só proMETO o que eu posso cumPRIR... inclusive... campanha eu vou gastar o que vou pagar... não vou fazer como outras candidaturas que devem dinheiro de campanha anteriores... que é o caso do Pt e do Psdb...

L6: em relação ao orçamento a ministra Dilma foi muito clara... pode ter suplementação e outras modalidades... mas o importante é falar da saúde... porque eu cumpri SIM... o que eu prometi... eu prometi durante a campanha que eu ia municipaliZAR a saúde... eu peguei a saúde de São Paulo... o Pas nas PÁginas da poLÍcia... eu recebi DOZE hospitais com-ple-tamente sucateados... 
tive que contratar VINTE e TRÊS MIL funcioNÁRIOS... e deixamos a saúde muito bem organizada... com QUEda de mortalidade infantil... queda de mortalidade materna... controlamos da DENgue que estava uma epidemia... construí sessenta por cento do hospital Tiradentes... colocam/ desapropriei o hospital M'BOI... fiz terraplaNAGEM para o hospiTAL... e a saúde começamos a informatização pequena na Lapa e deixamos PRONta para o grande salto que NÃO foi DADA... e as policlínicas não foram criadas... a população hoje não tem como fazer os seus exames laboratoriAIS e nem marcar a sua consulta de especialidades...

L1: quem pergunta agora é o candidato Ivan Valente...

L2: pergunta é para o candidato Kassab... Kassab já:: colocou aqui que ele vai continuar privatizando a saÚde... inclusive ele está recorrendo da DEcisão da justiça federal que mandou a prefeitura ASSUMIR a a Ubss e Amas e etc.... eu quero saber do Kassab se ele vai continuar DESRESPEITANDO a lei oitenta oitenta... do Sus... que pede que a saúde privada seja apenas complemenTAR... e parar de desmontar os SU/ os Sus em São Paulo...

L3: olha Ivan... muito obrigado pela pergunta... ela nos dá oportunidade em primeiro lugar de dizer que o Sus é de fundamenTAL importância para o nosso país e para a nossa cidade... e vamos continuar fortalecendo o Sus... fortalecendo o programa Saúde da Família... ALIÁS... criamos mais trezentas equipes... trezentas equipes... VAmos continuar reformando as Ubs... ampliando as Ubs... ALIÁS... criamos... construímos mais TRINta e duas Ubs... são os postos de saúde... vamos continuar com os nossos parceiros... nós estamos respeitando a lei porque existe uma LIminar que nos ampara... nunca se investiu tanto em saúde Ivan... a lei nos obriga a investir QUINze por cento... nós estamos investindo VINte por cento... e digo para vocês... se precisar colocar mais dinheiro eu coloco... aprendi isso com o governador José Serra que foi o melhor ministro da saúde que o país já teve... não se brinca com saúde... não é justo para aquelas pessoas que não tem convênio... nós não darmos a ela o direito de ter uma saúde... um atendimento de qualidade... e eu quero dizer a você... que VAmos... com esses recursos... -- VINnte por cento do orçamento... -- continuar com o Mãe Paulistana... continuar com as Amas agora com as Amas para especialistas... continuar com o Remédio em Casa... continuAR e ampliAR... a lista dos medicamentos que são fornecidos gratuitamente... porque se há algo que nos enche de orgulho na nossa administração... é o quanto melhorou o atendimento público dos sete milhões e meio de usuários que dependem da saúde pública para tratar dos seus problemas...

L2: olha Kassab para mim... enten/ esse termo aí parceria... -- que você gosta de usar -- é um nome muito bonito pra indicar TRANSferência de recurso PÚblico para o setor priVAdo... pra indicar TERceirização e PRIvatização... o que ESTÁ sendo feito em São Paulo é uma SAbotagem à implementação do Sistema Único de Saúde... a nossa proposta é implementar um Sus CEM por cento PÚBLICO... gratulto e para TODOS... inclusive na sua gesTÃO... pessoa que já tem plano de saúde são atendidas priMEIRO... no pronto atendimento... não é a TOA que a população está reclamando... SEtenta por cento da população diz que é PÉssimo o serviço de saúde... que não HÁ ambulatórios de especialiDAdes... que se demora um ANO para fazer uma internação... por que é que a gente não implementa aquilo que está na constituiÇÃO... na LEI... e fica tranferen/ transferindo recurso público para o setor priVAdo?...

L3: olha Ivan... você precisa ficar menos em Brasília e mais em São Paulo... respeitosamente eu lhe digo isso... porque conversando com os usuários você vai perceber o QUANto eles estão felizes com o tratamento público de saúde hoje... você tem razão... trinta por cento... o número é perfeito... o lbope já disse isso... 
outros institutos de pesquisa... TRINta por cento dos usuários estão MUlto felizes com as TRANSformações na saúde pública... faltam setenta... antes era ninguém... e isso foi feito graças aos nossos valorosos servidores públicos pessoas que durante DÉcadas foram relegadas ao ÚLtimo plano... aprovamos na Câmara Municipal o novo plano de cargos e carreiras para eles... trouxemos os parceiros... a diferença entre EU e você... é que você considera esses parceiros como qualquer um... como essas organizações sociais que existem em alguns municípios... em alguns esTAdos e que são criminosas... as nossas não... nós temos orgulho de apresentá-las... a Usp... a Unifesp... a Santa Casa... o Albert Einstein... o Sírio Libanês... as Irmãs de Santa Marcelina... as Irmãs de Santa Catarina... vamos continuar sim com essas parcerias... sem esquecer de valorizar... de reconhecer

L1: tempo candidato...

L3:<smiles>[3H]</smiles>

L1: o trabalho de nossos servidores... quem pergunta agora é o candidato Gilberto Kassab... L3: eu pergunto pra candidata Soninha... Soninha... se tem algo que... nos enche de alegria e orgulho... são os avanços do ensino público na cidade de São Paulo... desde o início da gestão Dlversas ações... desde o início da gestão... uma melhoria MUlto grande da qualidade do ensino... e se tem um programa que nos toca muito fundo... -- e você que é mãe deve conhecê-lo -- é o programa Ler e Escrever... o qual coloca DOis professores na sala de aula no período de alfabetização

L1: [ tempo candidato...

L3:

visão em relação a ele... se eleita prefeita de São Paulo...

L4: o Ler e Escrever é um programa:: interessante de fato... houve alguns avanços na educação... os professores há muito tempo reivindicavam a incorporação de uma parte de suas gratificações ao vencimento BA::se... sobre o qual são calculados vários benefícios... e e que servem... né?... especialmente pro cálculo da aposentadoria... então isso de fato foi uma conquista e o grande mérito da gestão foi ter aBERto negociações foi... foi ter feito MUltas... extENSAS... PAcientes negociações com a categoria... que naturalmente não fica totalmente satisfeita... mas reconhece os avanços e e o aumento já... ahn... estabelecido em lei... o reajuste pros próximos... para as datas bases dos próximos dois anos... mas a gente tem muito chão ainda pela frente... ainda tem muito o que melhorar na educação... nós temos uma situação de defasagem inaceiTÁvel... de adolescentes na sétima... na oitava SÉrie... que tem dificuldade de interpretar um texto... em se comunicar por escrito... dificuldades com operações aritméticas simples... e dificuldade para lidar com o conhecimento com relação ao mundo geral/ ao mundo em geral... então éh... é preciso fazer um esforço MUlto grande de toda a sociedade... pra que se Corrija essa defasagem imediatamente... solicitar apoio... compartilhar as boas prática que existem dentro da própria administração pública... algumas escolas pública têm resultados muito melhores do que outras... QUANdo... têm de fato uma participação com comprometimento dos servidores públicos... da diretoria... da coordenação pedagógica... dos 
professores... e principalmente dos pais... onde o Conselho de Escola é forte... a escola funciona melhor... mas... tem muito o que fazer ainda...

L1: RÉplica do candidato Gilberto Kassab...

L3: o programa reduziu o índice de analfabetismo... era TRINta e CINco por cento no final do segundo ano... hoje oitenta e cinco por cento das crianças são alfabetizadas até o final do segundo ano... eu queria aproveitar aqui e dizer pra exprefeita Marta... que ela Llcitou as obras... quando ela fala licitar... aliás o governo dela gostava de licitar... eram diversas licitações... ela entende isso como uma obra sua... eu não sou daqueles prefeitos que gostam de colocar o nome em placa... eu gosto de fazer o que é melhor para a cidade... e eu tenho da/ dado tudo junto com a excelente equipe para que a gente melhora/ melhore a qualidade de vida da cidade... o que eu quero dizer a você Soninha... é que além do Ler e Escrever... nós acabamos com as salas de lata... acabamos com as escolas de lata... vamos acabar com o terceiro turno... aprovamos um projeto na Câmara Municipal de reestruturação de CARgos e salários para os professores... eles estão valorizados... reconhecidos... e VAmos continuar valorizando os professores na próxima gestão... e digo para você... nós temos certeza absoluta... que com alguns anos... com o nível de investimento e de austeridade na gestão... nós vamos voltar a ter um ensino público igual ao ensino particular... porque isso

L1: tempo... tempo

candidato...

[

L3:

fazer justiça social...

L1: TRÉplica da candidata Soninha...

L4: sim tivemos avanços... mas como eu disse... ainda ainda restam muitas deficiências... ahn... no ensino para jovens e adultos por exemplo... na grande demanda que existe por qualificação profissional prá jovens e pra adultos também... é uma pena que a gente tenha que antecipar a entrada dos jovens no mercado de trabalho por falta de/ por necessiDAde de ajuDAR no susTENto da da faMília... mas o fato é que isso acontece e tem uma uma carência muito grande... a inclusão de crianças com deficiência ainda é algo que precisa avançar muito também... ahn:.... quanto aos Ceus... de FAto essa prefeitura não tinha interesse em continuar com o projeto e foi a custa de muita insistência que retomou... mas não é verdade que era só querer para começar a fazer no dia seguinte... porque havia terrenos $\mathrm{m} /$ em condições irregulares do ponto de vista da situação ambiental e algumas outras... mas felizMENte... o bom projeto dos Ceus... dos quais/ do qual eu sou muito fã... foi retoMAdo... mas ainda há algo a resolver por exemplo em relação à qualidade de ensino no próprio Ceu... o rendimento das crianças que estudam nos Ceus não é melhor que o rendimento das crianças da... do resto da rede pública...

L1: o PRÓximo a pergunTAR aGOra é o senhor PAUlo Maluf...

L9: eu pergunto ao candidato... Geraldo Alckmin... quando prefeito da primeira vez... é de minha autoria o projeto de lei... para a criação da secretaria municipal da CULtura... quando governador... também foi meu o projeto de lei para criar a secretaria de Es::TAdo da cultura... inclusive muitos festivais... quando candidato à presidência da república... estava no meu projeto de lei... criar o Ministério da Cultura.... que Tancredo criou depois... eu pergunto... qual é o seu projeto para a culTUra... aqui na cidade de São Paulo?... 
L8: eu quero éh... responder ao candidato Maluf... dizendo que esse/ essa é uma prioriDADE do meu programa de governo... porque SÃO Paulo que foi a capital da inDÚSTRIA... hoje ela vai se consolidando como uma capital mundial de SERviços e inclusive com... deve crescer a importância do turismo de negócios... hod/ hoje as pessoas ficam no máximo DOis dias em São Paulo e nós precisamos manTER mais as pessoas aqui para comprarem mais... movimentarem mais a economia... gerarem mais emprego e mais RENda... então São Paulo precisa ser a capiTAL da CULtura... o Governo do Estado... o governador Mário Covas e o meu governo... nós investimos muito na cultura aqui em São Paulo... éh... o museu da Língua Portuguesa que inaugurei antes de deixar o governo... e fico feliz que na estação da LUZ... onde hoje é o museu da Língua Portuguesa nós temos o seGUNdo museu mais visitado do país... ah... o novo prédio da Pinacoteca do Estado... ah:.... a estação Júlio Prestes que foi convertida na melhor sala de orquestras eh... do país que é a SAla São PAUlo... éh... a Orquestra Sinfônica do Estado de São Paulo a Osesp hoje é uma das melhores orquestras do mundo... o projeto Guri... por onde já passaram cento e cinquenta MIL crianças e jovens... um grande projeto de inclusão social... e eu vou como prefeito de São Paulo... se deus quiser... fazer a Broadway paulistana... ou seja... REvitalizar O CENtro de São Paulo... com GRANdes investimentos na área cultural... e levar os bons projetos para as regiões mais distantes...

L9: quero dizer ao candidato Geraldo Alckmin... que quando prefeito... eu tive um dos meLHOres secretários da culTUra da prefeitura... que foi o Rodolfo Konder... foi até espantoso que ele sendo comunista... foi convidado por mim e aceitou e foi o melhor secretário de cultura dessa cidade... nós fazíamos MIL eVENtos... não eram eventos elitistas não... MIL eVENtos por mês... de fotografia... de escultura... de música... em todos os bairros... na último ano da minha gestão fizemos DOze MIL eventos... doze mil eventos... portanto eu vou transformar São Paulo na capital da cultura brasileira... cultura clássica... cultura de escultura... cultura da fotografia... cultura da música popular... a cultura da música sertaneja... ou seja... a cultura tem que fazer parte do dna do paulistano...

L8: a cultura é uma prioridade... éh... do meu programa de governo... nós vamos DEScentralizar a Virada Cultural... ela será a Virada das EStações... nós faremos em cada ENtrada das estações do ano uma virada... e levando a TODAS as regiões de São Paulo... sul... leste... norte... oeste... enfim... DEScentralizando... investir nas bibliotecas... éh... nos TELEcentros... vou colocar a lei Marcos Mendonça... a Lei Mendonça... FORtemente... para poder ter FOmento através da iniciativa privada... hoje ela tem um investimento muito pequeno... e nós vamos CREScer o fomento para cinema... teatro... eh... artes cênicas... pintura... literatura... circo aqui mencionado... vou colocar recursos no PRóprio ORÇAmento e fazer um GRANde proJEto de INclusão sociAL... éh... pela cultura... e SÃO Paulo... que vai sediar a Copa do Mundo de $2014 .$. nós vamos criar um novo CENtro com a iniciativa privada de eventos... porque o Anhembi já está lotado... consolidando São Paulo... essa grande capital mundial...

L1: a PRÓxima perGUNta é do candiDAto ReNAto Reichmann...

L5: vou perguntar para o deputado Paulo Maluf... deputado... São Paulo tem um grande déficit de SAlas de aula... de atendimento MÉdico... como é que nós vamos faZER para resolver esse problema... paGANdo oitocentos... novecentos reais para um professor... ou pagando vinte e cinco reais por hora para um médico trabalhar a três... quatro horas de distância às vezes da casa dele... da onde que vem os reCURsos pra pagar apropriadamente o profissional?... já que equipamento sozinho não faz nada?... 
L9: eu gostaria de informar ao candidato Reichmann... e a cidade de São Paulo... que o PRImeiro e Único plano de descentralização da saúde... foi feito pelo governador Paulo Maluf quando TEve como seu secretário do estado da saúde o professor Adib Jatene... reconhecido mundialmente... como dos meLHOres cirurgiões e melhores administradores... ou seja... leVAmos o projeto ao Banco Mundial... o Banco Mundial aprovou... porque até então... a maioria dos hospitais estavam todos eles no espigão da avenida Paulista... quem tivesse por exemplo... uma acidente em São Miguel Paulista... ou em Capão Redondo... e precisasse de uma neurocirurgia... ele morria à caminho do hospital porque demorava uma hora para chegar até lá... pois bem... então TOdos esses hospitais... que TOdos os governos depois construíram na periferia... foi o PLAno de saúde pública feita pelo governador Paulo Maluf... e pelo secretário Adib Jatene... e que foi submetido e aprovado ao Banco Mundial... ora... o que eu quero dizer pra população de São Paulo... que saÚde não é só verba... verba é importante... veja... no plano do orçamento eu com vinte e quatro bilhões... quando prefeito... fiz MAis do que os outros com cento e cinquenta... ou seja... é GEStão... ou você administra a prefeitura como uma empresa... como um condoMínio... ou então você vai ter... infelizmente... deficiências em todos os setores...

L5: bom... lamentavelmente não foi respondida a pergunta que era... da ONde que vai vir os recursos para pagar Apropriadamente os profissionais... não dá para pagar médico a vinte e cinco reais a hora... não dá para pagar profeSSOR a novecentos reais ao mês a não ser que a gente que/ queira que ele trabalhe em duas ou três escolas e dê sessenta horas de aula... eu acho que existe aqui uma injustiça tributária... São Paulo é dezesseis por cento da economia do país... a arrecadação tributária do pais é UM trilhão... o nosso orçamento é dois e meio por cento... não dezesseis por cento... tem parte que a união precisa... mas o preFElto de São Paulo... pelo menos na MInha administração... vai usar o PEso de dezeSSEIS por cento do Pib do país... de trinta e cinco por cento da receita do estado de São Paulo pra... fazer o governo federal e o governo estadual colaborarem MUlto mais com a prefeitura aqui... pagarem muito mais conta... há muito tempo em que eu não vejo uma placa aqui... FElto pelo Governo Federal... feito pelo governo estadual... é TUdo a prefeitura que banca...

L9: olha... eu fico muito agradecido ao candidato Reichmann... de me dar esta oportunidade de relembrar a população que QUEM melhor pagou os médicos na prefeitura de São Paulo foi o prefeito Paulo Maluf... quando eu assumi os médicos ganhavam em média MIL reais por mês... e quando os médicos diziam que tinham que ter cinco empregos... eu perguntava... como é que vocês vão trabalhar em cinco empregos?... então eles diziam/ mas doutor Maluf... ganhamos tão pouco que ou a gente está em cinco empregos... e eu disse então para eles... então vocês fingem que trabalham e a população finge que é atendida... então EU aumenTEI... e para... eh... para quarenta horas semanais... CINco dias a oito horas... eu aumentei o salário de mil para SEis MIL reais... e para vinte horas semanais... para TRÊS mil reais por mês... ou seja... eu posso dizer provadamente e comprovadamente que o prefeito Paulo Maluf foi o quem melhor os médicos... as enfermeiras... e os assistentes sociais na prefeitura...

L1: a PRÓxima a pergunTAR é a candiDAta Soninha Francine...

L4: candidato Ciro Moura já respondeu?... pois é candidato... ((a candidata ri)) como o senhor tem dito... parece que a gente vive num mundo em que tudo está resolvido em que não há nenhuma acusação de corrupção... em que ninguém nunca foi preso por acusações de corrupção... nunca respondeu a nenhum processo... ou nunca deixou de responder a processos... que simplesmente prescreVEram... cujo prazo se esgotou... parece que eu inventei a existência de 
troca de favores entre o executivo e o legislativo... condicionando a aprovação de projetos de lei... mas digamos que não seja assim... ahn:.... que o mundo realmente não não tenha nada disso... éh:.... como o senhor lidaria com 0 parlamento na numa gestão sua?...

L7: bom... primeiro eu quero dizer a você que:.... eu já até citei que em determinados momentos aqui... eu me imaginei naquele programa assistindo Rolando Lero... ou então naquele filme Alice no País das Maravilhas... então veja... eu sei que você foi desafiada aí pra falar sobre o seu comportamento e eu tenho um compromisso com a população de São Paulo... que é tolerância zero com a corrupção... então veja e é assim que tem que ser... agora cada um... que responda... como quiser... em relação às suas coisas... eu quero responder... para São Paulo... um mundo novo... uma nova idéia... que é o Plus Saúde um plano municipal de saúde onde a população vai ser atendida pelo serviço público... ou pelo serviço particular e a prefeitura vai pagar a conta... sabe por que?... não/ não o serviço público já está pago... e não te atende bem... então você vai para a iniciativa particular... credenciada... fiscalizada pela população... e vai ter dignidade... e nós cumpriremos aquilo que está previsto... agora corrupção é coisa seríssima... É CRIme... é caso de poLícia... e comigo É caDEla... e eu sou... por isso que eu digo Soninha que eu sou diferente... EU quando falo... eu CUMpro...

L1: sua réplica... candidata Soninha...

L4: é num mundo ideal a aprovação de projetos no parlamento dependeria simplesmente do conteúdo dos projetos... dos parlamentares se posicionarem contra ou a favor a eles... no mundo real não é assim... é feito... éh/ tudo depende de acordos políticos... do estabelecimento de de contrapartidas vamos dizer assim... que podem ser MAis republicanas ou menos... MAis no interesse público ou menos... não adianta simplesmente partir para o confronto... ou o chefe do executivo não consegue aprovar nada no parlamento... então se É preciso negoClar... que a negociação se dê em bases republicanas... porque parlamenTAres condicionam SIM o apoio ao governo... À possibiliDAde de indiCAR... UM secreTÁrio... um dirigente de uma empresa estaduAL... ou de uma empresa estatal de nível federal... ou de indicar um sub-prefeito... então que a indicação seja feita com base em mérito... em qualificação... que o sub-prefeito indicado por uma bancada de vereadores possa ser sabatinado pela imprensa... pela população... que a população... a sociedade civil organizada... possa referendar a escolha do sub-prefeito e compartilhar a responsabilidade com a Câmara e com o prefeito por isso...

L7: Soninha... eu prefiro realmente essa sua maneira transparente e pura de colocar a situação... se não vira aqui as promessas que ninguém vai fazer isso... mas a troca na política... ela é natural... é sempre aquela discussão do es-paço... ela não pode ser esPÚria... ela não precisa ser esconDlda... e que a pessoa que seja indiCADO pelo vereador... pelo depuTAdo... tem capaciDAde... tenha curriculum para tanto e acima de tudo... conduta ética e competência... então você não fez ne/ você não... não reinventou a roda... você chamou a atenção para um assunto... e que eu tenho certeza absoluta que... e eu concordo com você... você está pedindo TRANSpaRÊNcia... pára de enganar a população de São Paulo... eu não fiz... eu não vou fazer... não é bem assim... é assim mesmo... mas o que não pode ser é espúrio... eu entenDI a sua colocação... e você não pode também aqui... dar nome de ninGUÉM... sob pena de não ter prova CLAra... você sabe o que acontece não materializa a prova... e vai você entrar numa linha de crime... o povo sabe Dlsso Soninha...

L1: o próximo a perguntar... é o candidato Geraldo Alckmin... 
L8: eu pergunto ao candidato... Ricardo... Reichmann... Renato Reichmann perdão... hoje percorrendo o Rio Pequeno... Reichmann... eu encontrei uma senhora numa farmácia com uma criança no colo... e ela dizendo... olha Geraldo a minha situação... eu preciso trabalhar... eu sou mantenedora da casa... e não tenho como deixar a minha filha... TRÊS anos de idade... uma menina até pesadinha... ela falou olha como é que eu trabalho... eu tenho que atender os clientes da farmácia... segurando a minha fila/ no colo por falta de vaga em creche... tem CENto e dez MIL crianças sem vaga em creche... e QUArenta e oito MIL crianças de quatro e cinco anos sem escola

L1:

[

L8: sua pergunta... candidato...

[

L5: bom... desde o começo do programa... d/ aliás... desde o começo da/ propaganda política e desde o começo de minha carreira que eu venho insistindo nisso.... a questão da educação de zero a dez é a base da sociedade... essa é uma decisão que Nós temos que tomar como sociedade... onde nós vamos priorizar o investimento?... partindo do princípio que de momento o valor que nós temos é fiNlto... são vinte e cinco Bllhões de reais de orçamento... aonde nós vamos aplicar?... minha opinião... aplica-se mais na educação e educação a/ aí é CREche... enSIno fundamental... então TEmos que investir o dinheiro aí... da onde vamos tirar é questão de senTAR e discuTIR... inclusive com o parlamento e eu acho que tem que ter uma abordagem com o parlamento que obviamente 0 parlamentar tem a sua BAse... o vereador tem a sua BAse eleitora tamBÉM... então... é NEsse momento... que o cidadão também... na hora de voTAR... não é um exercício de fuTUro... ele tem que olhar o que aQUEle vereador que devia defender ele... fez pro passado... se ele fez BEM fica... se ele fez mal vai embora... é uma auditoria... então é RE-aloCAR recurso... NÃO POde haVER... não vou nem falar da questão legal... questão legal... uma criança fora da escola... uma criança fora de creche... segundo o Estatuto da Criança e do Adolescente... já dá processo contra o executivo... porTANto... esTOU falando da questão moRAL... deiXAR uma criança fora da creche ou com ensino de baixa qualidade é InadmiSsível... tem que tirar o recurso de algum outro lugar... que POde esperar eventualmente... o futuro da criança não...

L8: olha... eu quero... éh... cumprimentá-lo Reichmann... pelo seu compromisso e dizer a vocês que está em casa que está nos assistindo até esta hora... de que governar é EScolher... não é possível uma cidade... a cidade mais rica do Brasil... nós termos CENTO e CINquenta e oito MIL crianças fora da escola... pré-escola... criança de QUAtro e CINco anos de idade... quaRENta e oito MIL na fila... eu terei isso como obsessão... DESde o primeiro dia... até porque a criança que... com quatro ou cinco anos que fizer a Emei... ela vai enTRAR no primeiro ano praticamente já sabendo ler e escrever... e aumentar ao MÁximo as vagas... cresceram o número de crianças sem creche... nós vamos atender ao MÁximo... para que a MÃE possa ter TRANquilidade... segurança de que seu filho vai ser bem cuidado... a outra prioridade nossa além da Emef será o ensino TÉcnico e tecnológico... JUNto com o Governo do Estado... já conversei com o governador José Serra... para nós ampliarmos FORtemente as escolas técnicas...

L5: a/ até porque investir em creche acima de tudo é uma atitude de inteligência política e administrativa... quando eu faço uma obra de dez milhões... provavelmente oito milhões vão para fora da cidade... vão para pagar alguma coisa fora da cidade... quando eu gasto dez milhões... eu invisto dez milhões em creche... são DEZ milhões de dinheiro que continua circulando aqui... dentro da 
comunidade da maneira MAIS saudável pro município que ainda acaba gerando emprego PERto de casa... essa creche que está sendo feita vai gerar emprego provavelmente para a própria MÃE... que eventualmente vai estar cuidando do PRÓprio filho na creche... porque ela trabalha lá... então GEra-se emprego no local e mantém o dinheiro circulando DENtro de São Paulo... que potencializa o uso do dinheiro porque o dinheiro vai render duas ou três vezes POR ano... vai pagar salário... e vai gerar riqueza... e vai gerar melhoria da qualidade de vida... portanto não entendo porque que não se prioriza... eu acho que temos que priorizar e mandar essa mensagem claraMENte no dia cinco de outubro nas urnas... para quem quer que seja... mas o compromisso tem que ser... educação... criança... e deixar o dinheiro PULverizado aqui dentro...

L1: quem pergunta agora é a candidata Marta Suplicy e a senhora só pode perguntar... pela ordem do debate... só restou o candidato Ivan Valente...

L6: com muito prazer... Ivan... segundo os dados da própria secretaria de saúde houve um aUmento de mortalidade materna na cidade de São Paulo... e segundo a ong Nossa São Paulo... houve um auMENto de gravidez precoce... éh:.... em dezeSSEte das trinta e umas subprefeituras... também com decréscimo de atendimento à pop/ à mulher negra... eu quero saber qual é a tua proposta PAra a saúde da mulher...

L2: bem Marta... primeiro eu queria dizer o seguinte... todos os dados que você mostra são... éh... dados que mostram a Plora do sistema de saúde de São Paulo... inclusive é algo que vem de várias gestões... inclusive da SUA... e no Kassab ela piorou ainda... tanto que o Kassab acabou de falar aqui que ele está satisfeito que tenha trinta por cento... mas o que eu q/ o que mais me chocou é o seguinte... veja... você sabe que... nós devíamos já ter implantado o Sistema Único de Saúde há muito tempo... é uma proposta dos movimentos sociais e agora eu acabei de ver você falar e eu fiquei pasmo... inclusive eu queria que você me respondesse... você defende as organizações sociais... você está defendendo terceirização... transferência de recurso público e privatização da saúde... eu até queria te perguntar o seguinte... o $\mathrm{Pt}$ mudou de posição?... porque se Nós implantarmos o Sistema Único de Saúde nós vamos ter dinheiro para TUdo... inclui/ inclusive para a saúde da mulher... ter o acomPANHAmento necessário... no PRÉ-natal... de SEte avaliações durante a gestação... do acompanhamento posteriOR... o que há hoje... é sofriMENto na saÚde... então nós deveRíAmos dizer claramente para a população que nós vamos implantar o Sus... o Pt mudou de posição?...

L6: você está enganado Ivan... em referência a que nós tivemos uma PIOra na saúde... piora nenhuma em relação ao que eu recebi que foi o Pas... nós conseguimos municipaliZAR e além disso tivemos uma DIminuição da mortalidade maTERna... da mortalidade infantil... do controle da DENgue na cidade que quando eu entrei era uma epidemia... e também diminuição de câncer de mam/ éh... de câncer de Útero... de tubercuLOse... e também de transmissão de materna de Aids... então foi uma melhora em TOdas/ as áreas... inclusive nós temos aqui também para repaRAR que essa piOra na saúde da mulher que realmente ocorreu... deve ter muito a ver com o programa de Saúde da FaMília... que nós recebemos duzentos que foram municipalizados... criamos seisCENtos equipes Saúde da FaMília... e ao contrário do que diz o... o o Kassab... éh... os dados que eu tenho não são da criação de trezentas equipes... são de duzentas... sendo que centro e cinquenta não tem MÉdicos... então são equipes que malfuncionam...

\section{L2: ôh Marta você não respondeu minha pergunta}


L6:

porque sou eu que pergunto...

L2:

e eu

perguntei para você se vocês mudaram de posição... você não me respondeu pelo seguinte... vocês muDAram de posição... tanto é assim que hoje se gasta mais de trinta por cento com o setor privado... você mesmo acabou de defender as Amas aí... e as Amas estão terceiriZAdas... toTALMENte terceirizadas... e Ama é apenas PRONto-atendimento... o Kassab falou um negócio aqui que tem atendimento complexo em ama... impressionante... vamos parar de enganar a população... VAmos paRAR de diZER... que a população vai ser atendida agora por entidades como o EINStein aqui do Morumbi... aqui do LAdo... isso é uma BRINcaDEIra... isso é explorar a boa fé da populaÇÃO... o que nós temos que fazer é dizer o seguinte... tem recursos para a saúde vamos contratar os médicos... equipes multidisciplinares... vamos fazer/ ambulatórios de especialidades... e garanTIR saúde PÚblica para TOdos...

L1: vamos agora a um rápido intervalo e voltamos a seguir com o último BLOco... eleições DOis mil e Olto... debate... você decide na BANd...

(( vinheta musical junto com a fala de L1))

(( intervalo comercial))

L1: neste bloco cada candidato terá DOIS minutos para fazer as considerações finais... aqui a ordem do primeiro bloco se inVERte... começando então com o candidato PAUlo Maluf...

L9: Boris... eu quero agradecer... à população de São Paulo... que ficou acordada até este momento... numa atitude Cĺvica de cidadão pra escolher o melhor... mas me permita telespectador falar um pouco com o meu coração... na plaTEia tenho dois $\mathrm{n} /$ netos meus... Fabinho e o Tavinho... eu quero que vocês saibam que administrar uma cidade deste tamanho... é em ponto menor... como administrar uma loja... um condomínio... uma fábrica... precisa de administrador... e quero dizer ao Fabinho e ao Tavinho... que tenham orgulho do avô que vocês tem... porque em QUAtro ano... com vinte e QUAtro bilhões de orçamento... fiz MAis... -e ninguém me desMENte... -- que todos aqueles que vieram depois de mim com cento e cinquenta... ou seja... eu sei COmo administrei ESta cidade... e digo com orgulho... que o doutor Paulo entrou na política há qua-ren-ta e DOis anos... e mora na mês-ma ca-sa desde quando ele entrou... e perguntem também... quantos políticos deste país... MOram na mesma casa depois que entraram na política... quantos políticos não mudaram de casa para meLHOR?... estou... há quaRENta e DOis anos também no mesmo partido... ou seja... perguntem QUANtos estão há QUArenta e DOis anos no mesmo partido... e eu não preciso de LEI para não mudar de partido... agora FAlo para voCÊ eleitor... o/ o tribunal eleitoral diz cuidado... não vote mal senão você vai ter quatro anos de sofrimento... cê precisa toMAR uma atiTUde... pode ser boa ou pode ser ruim... cuiDOdo... NÃO tenha MEdo de ser feLIZ... TOme uma BOa atiTUde e VOte em MaLUF... na urna... Número onze...

((aplausos))

L1: por favor senhores... por favor... com a palavra agora o candidato Geraldo Alckmin...

L8: eu quero agradecer à você... à senhora... ao senhor... ao amigo que ficou assistindo este nosso debate... ouvindo as nossas propostas... e dizer que eu tive a honra de ser governador de nosso estado... saí com a MAlor aprovação... seSSEN-ta e no-ve por cen-to de Ótimo e bom... e noventa por cento praticamente incluindo regular... quero agrad/ dizer muito obrigado a você por essa confiança... e como governador... cuidei dos seis-cen-tos e qua-ren-ta e cinco municípios do 
Estado de São Paulo... parcerias... convênios... um conjunto de trabalhos... inclusive aqui em São Paulo... obras importantíssimas... a Usp Leste... fico feliz quando jovem me encontra e diz olha... estudei na Etec... estudei na Fatec... entrei na Usp Leste... vou de trem pra Usp Leste... éh... dos hospitais... dizer olha... eu pude estudar porque entrei na Escola da Família então fiz a faculdade de graça... resolvemos o problema do Tietê... que desafiava décadas o problema das enchentes na Marginal do Tietê... o CarandiRU... que parecia uma coisa insolúvel... hoje só no filme do Hector Babenco... trabalhamos em todas as áreas... e eu peço o seu voto... pra poder me dedicar a essa nossa cidade... a essa cidade que $(\ldots)$

(( interrupção da gravação))

(( sequência de entrevistas após o debate))

L2: propostas muito semelhantes... as nossas... vão atacar problemas de FUNdo... com participação popular... e atacar os interesses dos poderosos... para universaliZAR direitos... para distribuir renda é preciso ter uma proPOSta que não se baseie em financiamento privado de campanha... por isso nós conseguimos mostrar que nós temos uma proposta alternativa para São Paulo...

L12: obrigada candidato... Patrícia Zorzan...

L13: nós vamos conversar agora com o candidato do Dem Gilberto Kassab... prefeito... o senhor subiu o tom agora no deba::te... inclusive aproveitou as considerações fiNAis para ataques à Marta e Alckmin... esse deve ser o tom daqui para a frente?...

L3: não... de maneira alguma... o tom da campanha continuará sendo apresentando as propostas... mostrando as realizações e comparando as propostas que temos em relação às propos-tas dos outros candidatos... e as realizações que temos em relação às realizações daqueles que já ocuparam o cargo público... para o eleitor identificar com clareza qual é o melhor candidato... qual é o candidato que melhor atende as suas expectativas em relação ao futuro da cidade de São Paulo...

L13: como é que o senhor avalia a participação do senhor?...

L3: olha... eu fico bastante satisfeito de ter tido a oportunidade de participar deste debate... MAis uma oportunidade para mostrar a MInha gestão... e as MInhas propostas para o eleitor... e que possamos ao longo desta campanha ter outros debates... para continuar discutindo a cidade e para dar a oportunidade para 0 paulistano escolher o seu candidato...

L13: tá ótimo... obrigado... vamos agora com o repórter Eudes Júnior...

L14: obrigado... Patrícia... eu estou aqui com a candidata do Pps... Soninha Francine... que avaliação fazer do debate?... o que pode mudar na campanha a partir deste debate?...

L4: ah:.... talvez alguns dos temas levantados aqui na discussão apareçam mais fortemente nos próximos dias... e na verdade eu espero... como já aconteceu da outra vez que a imprensa... faça o levantamento de algumas coisas que foram ditas aqui para ver se elas realmente conferem com a verdade...né?... se se os dados são são reais... se os resultados são aqueles que foram apresentados aqui... ah... o Pas teve noventa e dois por cento de aprovação... eu fiz isso... a segurança... no meu governo foi um espetáculo... ((risos)) eu resolvi o problema do transporte coletivo... isso tem que ser questionado...

L14: quais foram os temas mais importantes na sua avaliação?...

L4: olha a gente começou pelo trânsito... que é muito importante... porque envolve uma porção de coisas... envolve qualidade de vida:.... produtividade no trabalho... relações familiares... mas que bom que a gente não ficou só nisso... porque essa te/ é uma campanha que tem falando muito nessa questão do trânsito... o tema da 
corrupção apareceu bastante... né?... como lidar... executivo... legislativo... o que que é lícito e o que não é lícito estabelecer nos acordos...

L14: muito obrigado... vamos agora ao vivo com a repórter Sônia Blota...

L12: agora a avaliação do candidato Renato Reichmann... candidato... a avaliação do senhor?... temperatura subiu hoje...

L5: é... eu acho que tem que haver um debate mais FORte... ahn:....... também estranhei um pouco uma pergunta/ que recebi duas perguntas que recebi... um... eu recebi uma pergunta onde eu fui criticado por gastar pouco na campanha e outra... uma pergunta que não é da alçada sequer municipal mas eu quero comentar... a questão partidária... e aí re/ puxando da minha memória... quantidade menor de partidos... eu não sei se é melhor uma quantidade menor de partidos porque que eu lembre... na história do Brasil nós tivemos uma quantidade menor... no Estado Novo... de trinta e cinco a quarenta e cinco só tinha um... e durante a ditadura militar... de sessenta e quatro a oitenta e quatro... nós tínhamos dois... queremos um modelo com menos partidos?... ou ESSE debate é interessante?... eu acho esse debate foi interessante... curiosamente... muitas das propostas mais sólidas... vieram dos candidatos menores...

L12: esse foi o tema principal na avaliação do senhor?...

L5: o tema... éh... que que a senh/ desculpe... que que a senhora chama de... TEma principal?...

L12: esse debate que o senhor se referiu?...

L5: não... foi uma pergunta isolada mas que eu estranhei... eu acho que o tema principal foi bem focado que é educação e saúde... que são os fundamentos BÁsicos da vida... e educação... sem isso esquece porque todo o resto que a gente está faZENdo... nós vamos estar fazendo para nada... porque vai dar em lugar nenhum...

L5: muito obrigada candidato... Patrícia Zorzan...

L13: nós vamos conversar agora com a candidata do Pt... Marta Suplicy... candidata a senhora foi bastante atacada tanto pelo candidato do Psdb... quanto pelo candidato do Dem... isso preocupa a senhora?... a senhora acha que esse deve ser o tom daqui pra frente?...

L6: NÃO... eu não acho isso... eu acho... o que eu tenho... éh:... fico triste de não ter podido aprofundar foi a questão do metrô... porque nós falamos que VAmos colocar dinheiro do Governo do EsTAdo para fazer a extensão do metrô e que são poucos quilômetros... dois e meio três quilômetros... para as regiões mais carentes... como Vila Nova Cachoeirinha... Freguesia do Ó... Lapa... Sapopemba... M'Boi Mirim... Vila Maria... e eles não discutiram isso porque isso leva a uma questão mais profunda que é pra onde vai esse recurso do metrô... e eu estou propondo pra es/ as extensões para estas regiões... agora eu duvido que eles tenham coragem de ir nessas regiões... e Dlgam... com bastante crueza... que vai demorar... ViNte anos pro metrô chegar... na Vila Nova Cachoeirinha... ou Vila Maria... ou M'Boi Mirim...

L13: okay... muito obrigada candidata... nós vamos agora com o repórter... Eudes Júnior...

L14: Patrícia... eu estou aqui com o candidato do Ptc Ciro MOUra... que avaliação o senhor faz do debate?... o que pode mudar na campanha a partir deste debate?...

L7: olha... eu acho que foi um debate melhor que o primeiro... tenho certeza absoluta que a população de São Paulo vai começar a prestar atenção nas promessas que são feitas e não são cumPRIdas... e aquelas que não são feitas e são cumPRIdas custam caro para a população... nós não podemos nos esquecer dos pedágios... das taxas... que ninguém quis falar... eu até fiz uma ironia de um 
assunto muito sérios... quando eu falei do discurso do Rolando Lero... vimos Alice no País das Maravilhas... tá tudo resolvido... pelo que um/ não fez o outro fez... mas o povo de São Paulo... sabe muito bem qual é a realidade... e vai saber realmente... decidir o seu voto... que ele não QUER perder quatro anos...

L14: muito obrigado... vamos agora ao vivo com a repórter Sônia Blota...

L12: Eudes... agora é a vez do candidato do Psdb... Geraldo Alckmin... a avaliação do senhor sobre o debate de hoje...

L8: olha... eu gostei muito do debate porque você está na televisão aqui... duas horas e meia... praticamente... discutindo temas de São Paulo é sempre positivo... né?... esclarece o eleitor... foram saúde... educação... transporte... claro que 0 debate no segundo turno... com DOis candidatos só... ele é mais emocionante... né?... o debate com... éh... praticamente Olto candidatos... ele não tem a mesma... o... a... o mesmo calor que um debate do segundo turno... mas é positivo... acho que colabora pro eleitor... é um ponto importante da democracia... a Band está de parabéns...

L12: o horário eleitoral começou... o senhor acha que a temperatura subiu então?...

L8: o INteresse das pessoas vai aumentando... a medida em que vai chegando mais perto... éh... da data da eleição... nós estamos praticamente há vinte e cinco dias das eleições... então o quanto mais perto nós tivermos do processo eleitoral maior o interesse... acho que o debate foi bom... porque abordamos aqui a questão do ensino infantil... abordamos o GRAve problema dentro da saÚde... conversamos sobre transporte coletivo... foi muito positivo...

L12: muito obrigada candidato... vamos agora com a Patricia Zorzan...

L13: Sônia... nós vamos conversar agora com o candidato do Pp Paulo Maluf... candidato... boa noite... como o senhor avalia a participação do senhor no debate?...

L9: olha eu tenho que em primeiro lugar dizer que quem ganhou o debate foi a Bandeirantes... que a Bandeirantes... desde oitenta e dois... eu assisti o primeiro debate... Jânio Quadro versus Montoro e realmente foi instaLAda a democracia no pais... graça ao falecido... saudosa memória.... que está no céu... João Saade... e aos seus filhos... Ricardo e Jorge... em segundo lugar acho que fui muito bem... eu mostrei que eu sei administrar a cidade de São Paulo... com quatro anos e seis bilhões de orçamento... com vinte e quatro bilhões... eu fiz MAis do que os que me sucederam com cento e cinqüenta mostrei que eu sei administrar que sei fazer... e quem chega na Bandeirantes aqui... ou vêm pelos túneis do Maluf... ou pela Faria Lima do Maluf... pela Águas Espraiadas do Maluf... os pelas Marginais do Maluf... sabe?... eu tenho orgulho que ninguém passa em nenhum lugar dessa cidade sem uma obra que eu construí... muitas vezes com muito suor e muitas lágrimas...

L13: okay... muito obrigada... candidato... boa noite... nós vamos agora conversar com o repórter Eudes Júnior...

L14: Patrícia... eu estou aqui com o diretor de jornalismo da Band... Fernando Mitre... MAis um debate realizado... mais uma vez a Band cumpriu o seu PApel... dá um novo tom a essa fase final de campanha a pouco mais de três semanas para o primeiro turno?...

L15: não há nenhuma dúvida... esse debate foi um marco... eh... se você somar os eFEltos do primeiro debate... com a expectativa desse e mais os efeitos desse você tem o tom da campanha... o que vem por aí já está insinuado nesta fase inicial... através desses dois debates... você tem várias possibilidades de abordagem... por exemplo... possibilidades do segundo turno... nós vimos hoje aqui um ensaio do que poderá ser o debate do segundo turno... por exemplo... nos primeiros DEZ minutos de confronto... nós tivemos... de corpo inteiro... o conflito 
entre Alckmin e Marta durante dez minutos seguidos... no terCElro bloco... nós tivemos os mesmos dez minutos de confronto... dividido em duas partes... entre Kassab e e Marta... então já temos aí um ensaio... se não for o primeiro é o segundo... éh... é difícil que isso mude... pode até mudar em política tudo é possível mas a tenDÊNcia é essa... eu acho também... que os conteúdos ganharam um patamar mais adequado diante dos GRANdes problemas que São Paulo tem... os candidatos estão levando a sério essas muDANça nas pesquisas... essa mudança que mostra um eleitor diferente... mais exigente... mais racional... queRENdo de fato solução... para os problemas da sua cidade que são problemas cada vez maiores... eles de alguma maneira estão tenTANdo atender isso... é claro que... é insatisfatório... você não tem aí todas as soluções de corpo inteiro... mas uma tentativa dos candidatos de de fazer um discurso programático ficou claro... então são eleMENtos... são sinais do que vem por aí... ne/... nessa fase... nessa segunda fase da campanha...

L14: muito obrigado... e você fica agora com o Jornal da Noite... eleições dois mil e oito... debate... você decide... na Band...

(( vinheta musical anunciando o término do debate)) 


\author{
ANEXO 2 \\ Programa exibido no dia 12 de outubro de 2008, com duração de cento e \\ dezenove minutos e quarenta segundos. \\ L1: Boris Casoy. \\ L2: Marta Suplicy. \\ L3: Glberto Kassab. \\ L4: Fernando Vieira de Mello. \\ L5: José Paulo de Andrade. \\ L6: Sérgio Gabriel. \\ L7: Patrícia Zorzan. \\ L8: Fernando Mitre.
}

\title{
((Música de abertura))
}

L1: boa noite... começa aGOra o PRImeiro debate entre os candiDAtos à prefeiTUra de SÃO PAUlo neste seGUNdo turno... com este encontro a Band reforça MAis uma vez sua tradição de esTImular a discussão de propostas e ideias dos fuTUros governantes... hoje frente a frente nos nossos estúdios estão a candidata Marta Suplicy dos Pt... e o candidato GilBERto Kassab do Dem... na plateia... convidados dos partidos.... autoridades e jornalistas... estão conosco nesta transmissão ao VIvo... a Band News Tv... as rádios BANdeirantes Am e Fm e a Band News Fm... o debate também será TRANSmitido pela internet no band.com.br... vamos ver aGOra como será este PRI-mei-ro bloco... ( ) mediador será respondida pelos dois candidatos em ordem já definida por sorteio... o tempo para a resposta é de DOis minutos... na seQUÊncia... CANdidato pergunta para candiDAto... um minuto para a pergunta... DOis minutos para a resposta... réplica e tréplica de UM minuto cada... vamos aGOra... à pergunta... antes eu vou lembrar que em caso de oFENsa moral ou pessoal pode ser concedido DIRElto de resposta a critério de uma comissão formada espeCIALmente para esse fim... a pergunta a que me referi... escolhida a partir de sugestões dos leitores do jornal Metro é a seguinte... em CAso de viTória nesta eleição... o senhor ou a senhora se compromete a cumprir INTEGRALmente o seu mandato?... por ordem de sorteio... a candidata MARta Suplicy é a primeira a responder...

L2: boa noite Boris... boa noite espectador que tá em casa... boa noite ao candidato Kassab e... eu quero dizer para vocês que eu me comprometo... essa é uma pergunta que tem me sido colocada reiteradas vezes... e eu digo... eu esTAva de ministra DO turismo... e não estava pensando voltar a ser candidata... foi uma decisão difícil na medida em que estava fazendo MUlto como ministra do turismo e achando que tinha uma possibilidade de continuar a colaboração para a melhoria de uma área tão importante para o Brasil... que gera tanto emprego... MAS colocada a decisão eu avaliei que... quase que abri a página de novo... e falei BOM... eu VOU... eu VOU... mas eu quero ficar quatro anos... vocês entendam bem... eu vou quero fazer um governo tão bom que eu possa me permitir ficar oito anos... e é isso que eu espero... eu espero ganhar a eleição e espero ter a possibilidade de aRRUMAR o trânsito dessa cidade... que eu peguei caótico e arrumei... fazer mais corredores para fazer fluir esse trânsito... e o transporte... construir metrô... fazer a rede Ceu na cidade toda... construir mais vinte Ceus... ajudar a qualificação do professor para que ele fique também só num lugar dando aula... e NA saúde poder fiNALmente trazer para a cidade... que está esperando há tanto tempo... os exames MÉdicos de especiaLIDAde... e os exames MÉdicos de imagem... também na seguRANÇA... voltar a ter mais guardas municipais nessa cidade... e poder melhorar a qualidade de vida... e pensar 
GRANDE... que a nossa cidade... é uma cidade... que tem que ter proPoStas... inovaDOras... ouSAdas... muito semelhante a que eu já fiz na outra gestão... no sentido de pensar $\mathrm{O}$ fuTUro... planejar o fuTUro... da maior cidade brasileira...

L2: candidato Kassab...

L3: boa noite telespectadores... boa noite Boris... boa noite candidata Marta... uma satisfação participar MAis uma vez de um debate... e agora no segundo turno para que o eleitor possa... definitivamente resolver em QUE candidato vai votar para/... identificar aquele responsável para fazer a gestão da cidade de São Paulo... ficarei os quatro anos... posso tranquilamente assumir esse compromisso... assumi a cidade de São Paulo no lugar do então prefeito José Serra... que fez em um ano e três meses de gestão... uma administração muito firme... muito competente... e deixou as linhas mestras para que eu pudesse dar continuidade ao seu trabalho... tinha um plano de governo do qual eu fui solidário... do qual eu me comprometi com a cidade de São Paulo a dar sequência... dei sequência a esse plano de governo e hoje a cidade de São Paulo apresenta enormes avanços... avanços na qualidade do ensino... avanços na qualidade do da saúde pública... aVANços no combate à poluição... investimentos expressivos graças a boa saúde financeira da prefeitura que foi reconquisTAda... nos possibiliTAram inclusive fazer investimentos que a cidade nunca tinha/ experimentado antes... em primeiro lugar na saúde... a ex-prefeita no seu ÚLtimo ano de governo investiu UM bilhão e meio de reais na saúde... nós estamos investindo... já nesse ano de dois mil e oito... três bilhões e duzentos MIlhões de reais... e no ano que vem... no orçamento já encaminhado para a Câmara... estaremos investindo VINte por cento do orçamento... a lei nos obriga a investir quinze por cento... e em relação à melhoria da qualidade do ensino... todos sabem os aVANços que aconteceram... mas porém posso dizer a vocês... tenho a consciência de que os problemas ainda... não foram todos resolvidos... a cidade tem imensos desa/... desafios para a frente... e é... portanto... essa razão que eu me proponho a contiNUAR na prefeitura... para dar sequência a essas ações... junto com a exCELENte equipe que tenho... para que possamos durante quatro anos... concluir esses projetos que vão... INquestionavelmente melhorar a qualidade de vida de São Paulo...

L1: e agora candidato per-gun-ta para candidato... o primeiro a perGUNtar é o candidato Gilberto Kassab... um minuto para a pergunta... dois minutos para a resposta... de dona Marta SupliCY... réplica em um minuto... tréplica em um minuto...

L3: candidata Marta... na nossa gestão... demos sequência a um projeto... a um programa de REcapeamento e pavimentação que nunca tinha acontecido na cidade antes... TRIplicamos o volume pavimentado na cidade de São Paulo... eh... QUAdruplicamos 0 que foi recapeado... cuidamos melhor da cidade e... Evidentemente isso trouxe uma SÉrie de benefícios... principalmente para a população mais humilde da cidade de São Paulo... a pergunta que lhe faço é... POR que na sua gestão as áreas pavimentadas foram TÃO insignificantes... por que foram TÃO pouco pavimentadas na sua gestão?

L2: bom... primeiro eu quero começar que não foi tão pouco... haja visto a maneira que eu recebi a cidade... e do jeito que você particiPOU da gestão da cidade... porque a gente não pode esquecer... que KaSSAB... era secreTÁrio de planejamento de PItta nos dois primeiros anos... e ajuDOU a planejar a cidade... acaBOU com a cidade... eu recebi a cidade um CAos... como vocês todos lembram... um caos FINANceiro... um caos no TRANSporte... um caos na saúde que tinha o Pas... um caos em todas as direções... então eu comecei a reconsTRUIR a cidade... e quando se falava governo da reconstrução... candidato... eu não estava falando uma palavra... eu estava falando de verDÁde... 
eu tive que começar do NAda... até a subprefeitura você cheGAva... não tinha móvel... as pessoas não tinham motivação... eu informatizei todas as subprefeituras... criei TRINta e uma organiZAdas... as pessoas podem agora lidar com a internet... lá... reorganizei toda a cidade... e asfaltei MUlto... acho o asfalto uma coisa muito importante para a população... porque no asfalto você tem a pessoa não precisando mais andar na lama... andar de madrugada naquela situação... quando CHOve... é muito duro... então eu tive isso como uma prioridade... mas também tive que dar conta de tudo... aliás... eu fiz NA nossa gestão... NOve piscinões... SEte que eu dei o terreno e construí... dois que eu dei o terreno e o estado construiu... e foi tendo que reorganizar a cidade inteira... eu me sinto muito confortável com a sua pergunta... e PRINcipalmente... porque agora eu estou lembrando... sabe o que mais... o que MAis eu FIZ na periferia?... e que por isso me faz ter essa votação tão forte?... é alguma coisa que você está fazendo muito nos Jardins... porque eu vejo em cada côa/... quarteirão dos Jardins têm uma pracinha nova... né?... eu fiz praCINHA na periferia... você que está em CAsa deve lembrar a pracinha que eu fiz na sua região... eram regiões onde não tinham NAda... as pessoas iam para o bar se queriam ter algum contato... os telecentros também ajudaram... assim... para a juven::tude também... mas a gente fez muita coisa... e eu espero poder... com dez bilhões a mais... fazer muito mais...

L3: a população da periferia vai ter dificuldade de identificar as pracinhas da exprefeita... mas eu poderia... dizer... e lembrar aqui a ex-prefeita... que ela sempre recorre a administração de seu antessor/... antecessor... Celso Pitta... para citar a dificuldade de seu governo... a situação difícil que ela encontrou na cidade de São Paulo nós encontramos dificuldades em dobro... pela situação que encontramos... fila de credores... DOis bilhões de dívidas da cidade de São Paulo... e basta... relembrarmos... como era a cidade há quatro anos atrás... MAS para não desviar do assunto... até porque... você... não respondeu à pergunta... eu só queria lembrar que a nossa usina de asfalto produz hoje duas mil toneladas POR dia de asfalto... na sua época produzia só CEM toneladas... eu lhe queria perguntar... você sempre diz que faz um governo voltado para os pobres... e você coBRAva essa pouca pavimentação que fez... com a Ppuc... você vai continuAR com a taxa de asfalto?...

L2: CREdo... mas aí você inverte TANto... embaralha TANto... que a gente não sabe nem por ONde começa a desmentir... KAssab... eu estou PASma com o que você está falando... essa questão do asfalto comunitário... era um JElto de uma prefeiTUra FALIda... que VOcê deiXOU... conti/... consegui asfaltar essa cidade... a prefeitura pagava uma porCENTAgem... e a pessoa que morava naquela RUA... também pagava uma porcentagem... o que foi FEio... VOcê não esTÁ conTANdo... é que vocês uSARAM esse contrato que eu TInha... e... e... esse contrato pagava para as construTOras... MUlto mais... porque tinha muita inadimPLÊNcia... e aí vocês usaram o mesmo contrato... e continuaram pagando para as em/... para as construTOras... o mesmo preço do asfalto... esse detalhe você esqueceu... né?... e eu vou contiNUar diZENdo tamBÉM... de novo... e repetindo quantas vezes for necessário... eu não deixei a prefeitura falida... até o suPREmo TRIBUnal Federal aprovou as nossas contas... no pri... no FIM de janeiro você já tinha UM BIlhão e cem mil reais em CAlxa... e acabou o ano com dois BIlhões E MEio em CAlxa... então vai com calma...

L1: agora a pergunta cabe a candidata MARta Suplicy...

L2: candidato Kassab... eu apresentei... logo no início da campanha... uma proposta de Ceu profissionalizante... isto é... usar os Ceus à noite para dar curso técnico... logo depois você apresentou a mesma coisa... eu fiquei suPER 
SUrPREsa... porque em dois mil e seis já tinha sido apresentado por um... pela Câmara... aprovado por unanimidade... um projeto... exatamente igual... falando de curso/ de profissionalização no Ceu... e você vetou... e aGOra você vai e propõe... a pergunta que eu faço é... em que KASSAB a população deve acreditar?... No Kassab reAL que veTOU... em dois mil e seis aquele proJEto ou o Kassab da propaganda que agora diz que vai fazer Ceu profissionalizante... nos Ceus... haja visto que são dois Kassabs... um preFElto que está ali com a caNEta e o outro é o Kassab que você vê na propaganda... NÃO corresPONde... um veta e o outro na campanha diz que vai fazer...

L3: a população pode votar TRANquilamente no Kassab que vetou este projeto... até porque os cursos técnicos são de responsabilidade do Estado... e graças a essa parceria com o governador José Serra... nos estamos implantando em São Paulo... deZESSEis mil vagas em cursos técnicos... o que é um número extraordinário... e deixamos os recursos... aliás um volume de investimentos... eh... extraordinário... graças a... gestão e eficiência dos recursos públicos que temos em nossa administração... conseguimos acabar com as salas de lata... com as escolas de lata... melhorar a qualidade do nosso leite... aliás na administração da ex-prefeita... o leite era entregue NOve meses por ano... a um custo de nove reais o quilo... em nossa administração... no primeiro mês já de gestão... reduzimos para CINco reais o quilo... e passamos a entregá-lo DOze meses por ano... e hoje portanto... eu posso tranquilamente dizer que estamos cumprindo as nossas responsabilidades no ensino público... e também estamos apresentando... através da parceRIA com o Governo do Estado... uma alternaTIva viÁvel... uma alternativa eficiente... de trazer os cursos técnicos para a cidade de São Paulo...

L2: in Kassab... acho que agora você confirmou o que eu estava faLANdo... porque você diz que está fazendo em parceria com o Estado... mas na tua propaganda você falou outra coisa... na tua propaganda você falou que vai fazer curso profissionalizante no Ceu... mas eu gostaria de ler aqui... é o veto que você deu ao projeto... né?... diz assim... "seja por ferir a autonomia das escolas... seja por imputar ao município uma obrigação... que PEla legislação da educação NÃO incumbe priori/... prioritariamente a esse ente federativo... o projeto aproVADO não encontra razões para prosperar... enquanto de fato... o veto está escrito e assinado por você..." aí... você vai na propaGANda e diz que vai fazer curso profissionalizante nos Ceus... eu acho que tem que fazer mesmo... aliás... não enTENdo porque você não fez em QUAtro anos... porque essa populaÇÃO... o Brasil bombando do jeito que esTÁ... quer qualiFICAção... quer capaCltaÇÃo... quer emprego... e preClsa diSSO... quantos meninos eu não tenho VISto... com dezessete... dezesseis anos... que completaram cursos fundamenTAIS... muitas vezes até o curso MÉdio e precisa de uma qualificação... explique-se...

L3: olha Marta... é até constrangedor... mas eu tenho certeza que o nosso... telespectador entendeu... estamos CRlando deZESSEis mil vagas... dando terreno... o Estado entrando com a escola... numa parceria como deve ser feita... aliÁS... como eu tenho diversas também com o presidente Lula... em relação a quatro anos que eu não fiz... estou fazendo... tanto é que estou apresentando na minha propaganda... na minha... agora você também ficou quatro anos... e ale/... além de não ter criado nenhuma... de deZESSEis que tinham você fechou oito... é constrangedor...

L1: a pergunta agora... cabe ao candidato Gilberto Kassab...

L3: candidata Marta... inclusão digital é muito importante... tanto é que nós estamos praticamente triplicando o número de TELEcentros na cidade de São Paulo para poder levar a interNET... para poder levar oportuniDAde em especial para aqueles mais humildes e ter acesso à internet... as pessoas não tem 
computador... tem dificuldade de fazer esse investimento... e você veio nessa campanha com a proposta da internet gratuita para toda a cidade de São Paulo... sabemos que... a única cidade no mundo... que implantou a internet gratuita foi a cidade de Taipe... em Taiwan... AQUI no Brasil... aliás uma cidade administrada pelo seu partido... o Pt em JacaREÍ... está tentando... a um custo de TREzentos milhões de reais e está tendo MUlta dificuldade... eu queria que realmente você explicasse porque essa prioridade de gastar TANTO num projeto que é de uma dificuldade muito grande de ser implantado... tanto é que não foi implanTAdo em NEnhuma cidade no mundo... só em Taipe... ao invés de gastar... por exemplo... em hospitais...

L2: olha... a primeira coisa... não é verdade... foi implantado em VÁrias cidades do mundo... inclusive aqui no Brasil... e está sendo implantado agora em VÁrias FAvelas de Belo Horizonte... mas eu gostaria de dizer... quando você diz... ah... o custo é extraordinário... não tem custo extraordinário... Kassab... são sessenta e quatro milhões... mas SE tiVEsse CUSto EXTRAordinário... eu FAria... porque como eu fiz os telecentros... eu BANquei aquilo... e era o SEU PARtido que dizia... NÃO FAça... votaram contra... vai... vai poder... VÃO roubar TODOS os telecentros da periFERIA... vão roubar os computadores... se eu não acreDItasse que a periferia tivesse direito a ter TELEcentro... a poder aprender a mexer no computador... a ter CURso... que aGOra eu SOUbe... em VÁrios lugares que eu fui perto de telecentro... que você retirou os cursos graTUltos do telecentro... eu não teria feito... a gente tem... não só QUE soNHAR... mas faZER... e eu VOU faZER... e vou dizer mais... vou explicar... como é que eu vou fazer... o... nós vamos colocar as antenas nos prédios públicos da cidade de São Paulo... a cidade de São Paulo tem TRÊS mil prédios públicos da prefeitura... nós vamos colocar as antenas ali... e as pessoas em QUINHENtos metros... num raio de quinhentos metros... vão captar esse siNAL... depois nós vamos averi... nós vamos começar da periferia pro centro... e aí nós vamos ver aonde não está captando... vamos ter ilhas... e nós vamos ter as torres... que aí são mais caras... mas nós vamos cobrir de imediATO... dá para cobrir... em quatro anos... a cidade TOda... e ao mesmo tempo já ir fazendo umas ilhas... eu... umas torres... eu não sabia... e fui/... e soube recentemente... pelo ministro de comuniCAÇÕES... que tem um conVÊnio já feito com as telecomunicCAÇÕES... que você também não deve conhecer... que oitocentas... que todas as escolas muniCIPAIS vão ter agora links que são pagos pelas teles... e nós temos em São Paulo oitocentas escolas municipais... nós quando fizemos o custo... nós nem coloCAmos esse... isso aí que vai vir... então vai ser... é perfeitamente factível... e eu vejo que vocês MO::RREM de medo...

L3: Marta... nas escolas públicas já estamos implantando internet... inclusive em diversas delas com TElecentros... eu volto a dizer... por ISSO que é importante a campanha... a Marta vai implantar esse projeto... quer implantar... o jornalista Etevaldo Siqueira... um especialista no setor... mostra que o custo é DOIS bilhões e duzentos milhões para a sua implantação... e demonstrou... provou... então a Marta vai fazer esse projeto... eu não... eu vou fazer mais hospitais... eu vou continuar pavimentando ruas SEM cobrar dos mais pobres... vou continuar... construindo mais escolas para que todas as crianças agora na próxima... no próximo mandato... fique cinc/... SEte horas por dia... nas escolas... nessa gestão acabamos com as salas de lata... com as escolas de lata... estaREMOS acabando com o terceiro turno assim que com/... concluirmos... o programa de construção de escolas... enfim... por ISSO que é bom campanha... a candidata Marta vai implantar a internet... parece mais aquele Ceu Saúde que ela apresentou na última campanha... um factóide... e eu vou continuar fazendo essas ações... para 
melhorar a qualidade do ensino público... os cuidados com a cidade... e a qualidade da saúde pública...

L2: olha... eu não FAlo factóide NÃO... eu não fui reeleita... eu não pude FAzer... vocês fizeram um MONte de promessas... as pessoas estão na saÚde esperando as suas promessas... mas em relação à internet gratuita... eu vou fazer SIM... porque isso é o fuTUro da nossa juventude... é o fuTUro das pessoas... outro dia... até uma senhora de IDAde... veio perguntar para mim se ia TER... e nós vamos fazer... porque realmente é um passo muito importante... agora ME es::PANta... você diZER... que eu vou fazer a internet graTUlta... e eu não vou fazer hospital... UÉ?... a saúde tem uma verba própria... a educação tem outra verba... e você tem um orçamento HOje que é dez BILHÕ::ES de reAIS a mais do que EU trabaLHEI... DEZ bilhões a mais gente... eu trabalhei com quinze... ele trabalha com vinte e cinco... e o orçamento que foi agora para a Câmara é vinte e NOVE... o que é VINte e NO/... são VINte e NOve BILHÕES... o que é sessenta e quatro milhões?... quer dizer... você está penSANdo muito pequeno... caBEça muito pequena... tem que pensar GRANde nessa cidade... e as pessoas tem direito e estão DOldas para ter internet gratuita e eu VOU FAZER...

L1: quem pergunta aGOra é a canDIDAta MARta Suplicy...

L2: candidato Kassab... em dezembro de dois mil e sete...a Câmara aprovou uma... uma... um projeto... e enviou para a sua assinaTUra... que era de licença maternidade de SEIS meses... para as funcionárias públicas... o senhor veTOU... agora esse ano... o senhor JÁ se apressou a mandar... um projeto CRlando essa licença maternidade de seis MEses... claro... o senhor tem uma adversária MULHER... que SEMPRE defendeu as mulheres... os direitos das mulheres e crianças... eu pergunto... por que agora pode uma coisa que não podia antes... agora... a minha questão é... a mulh/... a pessoa que está me escutando aí... em quem que ela tem que acrediTAR... no Kassab preFElto que veTOU a licença materNIdade... ou no Kassab da propaGANda... que pertinho das ELEIÇÕES... a... reapresentou o projeto... São DOIS Kassabs... UM que VETA... E VETOU... e o outro da propaganda que vai lá aGOra e diz que vai fazer licença maternidade para as funcionárias públicas...

L3: olha... só para concluir a última questão... eu queria dizer pra... candidata Marta... que na saúde... eu gasto MAIS do que lei exige... a lei diz quinze por cento... e eu gasto VINte... estou investindo vinte por cento... portanto não é que eu gasto... invisto apenas o que a lei prevê... e em relação aos vinte e nove bilhões em nosso orçamento... ela poderia também na sua... no seu goVERno... ter sido rigorosa na fiscalização com as empresas... e ter operado... feito uma fiscalização rigorosa para trazer as empresas de volta para a cidade de São Paulo... empresas que trabalham aqui e sonegavam impostos lá fora... nas cidades vizinhas... fizemos isso e aumentou a receita... EM RElação a esse VEto... o próprio veto explica... é inconstitucional porque só o poder executivo pode originar despesas... e é o que eu fiz... vetei e encaminhei um novo projeto para a Câmara... portanto estou muito tranquilo quanto $a$ isso... inclusive... por falar em mulher... me espantou muito no seu programa... Marta... você apresentar uma pessoa... e concordar pelo seu programa dizendo que o enxoval do Mãe Paulistana... mal dava para limpar uma pia... um programa que a gente com TANto carinho tem atendido miLHAres de mulheres... chegaram a quase treZENtas mil mulheres...

L2: olha o Mãe... o Mãe Paulistana era o meu Nascer Bem... e era tão melhor... que a mortalidade materna decresCEu na minha gestão e tá aumentando na sua... mas vamos deixar isso de lado e vamos falar do seu veto... porque... você disse que era inconstitucional... OLHA o seu veto o que diz... e aí você vai ter que expliCAR... bom... eh:.... "é questionável esse projeto porque... ter... questionamos 
essa necessidade de ampliação do período de licença à MÃE... VEZ que não há comprovação cienTífica do período ideal e necessário para esse fim..." é muito... ((palmas)) muito impressionante... e enTÃO... aí vocês vêm o prefeito Kassab... ele vem AQUI... ao VIvo.. fala essas COlsas... mas ele questionou... NA verDAde... esse direito da mulher... ELE quesTIOnou... NA verDAde... o que NÓS muLHERES sabeMOS... que/... que é muito melhor... para NÓS... para a NOSSA CRIANÇA... pro VíNculo... e ATÉ... Kassab... para economizar nos postos de saÚde... porque a criança que é amamenTAda... é uma criança MAIS saDÁvel... recorre menos a médicos... eu vou perguntar... você deu tanta explicação... mas a verdade é essa que eu falei agora... dois KaSSABS...

L3: agora a minha pergunta...

L1: não... a sua TRÉplica...

L3: é minha última tréplica... eu queria... registrar prÁ:.... candidata Marta... que tem tanta coerência o que eu falei aqui... que o projeto foi encaminhado... e tem tanta coerência a argumentação em relação a investimentos... que a senhora investiu UM BIlhão e meio no último ano de gestão... e nós estamos investindo TRÊS BIlhões e duZENtos MIlhões de reais... inclusive com programas notáveis na área da mulher... e o que eu queria lhe perguntar e deixar aqui no ar... quantas pessoas o seu programa Nascer Bem atendeu?... e também que você omiTIU AQUI que você foi obrigada pelo Ministério Público a implantar... porque era uma lei do vereador do Psdb... Carlos Alberto Bezerra... que a questionou no Ministério Público... porque não implantou esse projeto Nascer Bem... que na verdade não é SEU... é do vereador Carlos Alberto Bezerra... e você foi obrigada a implantá-lo e não atendeu ninguém... porque... eu quero que você apresente... pode ser durante a semana mesmo... para a imprensa... para a opinião pública... quantas pessoas foram atendidas por esse programa...

L1: no próximo bloco mais uma rodada de perGUNtas entre os candiDAtos... ELElções dois mil e oito... debate... voCÊ decide na Band ((aplausos))...

((Vinheta de intervalo))

L1: e voltamos com o deBAte com os candidatos à prefeiTUra de São Paulo... participam dessa transmissão $\mathbf{A O}$ Vlvo... a Band News Tv e as rádios BANdeirantes Am e Fm e Band News Fm... o debate também pode ser aCOMpanhado pela internet... vamos às regras desse segundo bloco... CANdidato pergunta para CANdidato em ordem JÁ definida por sorteio... um minuto para a perGUNta... DOis minutos para a resposta... RÉplica e TRÉplica de UM minuto cada... a primeira a perguntar é a candidata MARta Suplicy...

L2: bom... nós vamos perguntar... eh... para fazer essa comparação... do prefeito real e do prefeito candidato... né?... o CANdidato... ele promete várias coisas... licença maternidade... Ceus etc.... mas o preFElto de verDAde... que TEM a caNEta na MÃO... vejam vocês... ele enviou um projeto de lei à CÂMARA agora no mês de agosto... que CRIA o pedágio urbano... eu vou ler... está escrito assim... projeto de lei cinco... dois... quatro... propõe... "PLANEJamento e implanTAÇÃO de sisTEMAS de tráfego TARIfado..." isso quer dizer... peDÁgio urBAno... está assinado pelo senhor... foi para a CÂmara com a SUA assinatura... você já paga o pedágio mais cara do Brasil... e agora vai pagar peDÁgio para sair da sua CAsa... e a minha pergunta é a seguinte... se o senhor foi eleito... em quanto tempo o senhor vai implantar o pedágio... QUANto vai CUSTAR... e vai começar por que regiões da cidade?...

L3: candidata... candidata... o telespectador precisa saber a VERdade... qual é a Marta... essa... ou a Marta que omite a informação que no dia seguinte... por conta desse equívoco... foi enviado um novo projeto em que não tinha mais esse pedágio urbano... até para explicar ao telespectador... a Secretaria do Verde e do 
Meio Ambiente deFENde o pedágio urbano... o prefeito... quando chegou o projeto para o prefeito... encaminhou sem o pedágio urbano... por um equívoco da nossa secretaria do governo... foi com ESSE item e... evidentemente... o prefeito coMANDA a cidade de São Paulo... e isso cês perceberam ao longo dessa gestão... o Cidade Limpa... o fechamento de Postos de Gasolina... o combate à sonegação de tributos... fazendo que nossas despesas aumenTEM... e esse item foi retirado do projeto... portanto não haverá em... pedágio urbano enquanto eu for prefeito de São Paulo... podem ficar muito tranquilo... diferentemente da exprefeita que tinha... na:: criação de taXAS e impostos... uma de suas principais virtudes de sua administração... tanto é que sua administração era conhecida com um apelido... portanto eu gostaria de dizer para vocês que NÃO CRlaremos o peDÁgio urBAno... e não criaremos novas taXAS em nossa administração... quem vê a ex-prefeita eh... se manifestar... até parece que... ela não foi prefeita... até parece que ela não teve oPORtunidade de fazer na cidade algo na saúde... na saúde... por exemplo... não fez hospitais... prometeu que faria... não fez as Amas... não valorizou os servidores da saúde... hoje a população aprova a nossa administração... todos sabem... VEja a pesQUISA... vejam as urnas... não é?... quando ela se manifesta aqui... parece que a população não está contente com a administração... parece que está o CAos a cidade... a população tem memória... candidata Marta... a população está conTENte sim com a nossa gestão porque nós fizemos muita coisa... e vamos continuar fazendo MAIS ainda na próxima gestão...

L2: bem... do jeito que você fala... foi pra lá... foi pra lá... enrolou e TAL... mas eu acho que nem você acredita no que... na história toda que você contou... e eu quero falar para você... que está em casa me ouvindo... o projeto TÁ LÁ NA CÂmara a segunda versão que ele falou... e a seGUNda VERsão fala em peDÁgio SIM... então você que comprou o seu carro com dificuldade... paga em seSSENta meSES... treZENtos e seSSENta reAIS por MÊS... não é?... você que está AÍ... em Itaquera... São Miguel... Freguesia do Ó... Vlla MaRIA... POde SE PREpaRAR... porque ele na progaGANda... está falando que NÃO vai faZER... aqui está falando que não vai faZER... que garantia ce tem?... se o homem quando tem proJEto... ele... ele... VETA e depois ele diz que vai fazer... agora ele diz que NÃO vai fazer... está fazendo o contrário... mas o projeto ESTÁ LÁ... por que não tirou o projeto?... essa é a minha questão... por que que não tirou o proJEto... aliás... esse peDÁgio urbano... não vai dar certo também... porque foi implantado EM LonDRES... NÃO deu CERto... ele oNEra as pessoas MAIS PObres... não... não é uma solução... agora... eu acho que... eh... você SEMpre propõe essas coisas... depois diz que não vai fazer...

L3: a garantia que a cidade tem... é a garantia... de uma administração séria... que há dois anos e meio está na prefeitura de São Paulo... usando bem o recurso público... não fazendo as despesas mais do que lei permite... não queBRANdo a prefeitura... PRlorizando aço... ações para as pessoas que dependem do ensino público... da saúde pública... com energia... implantando projetos na cidade de São Paulo que não tem custos... fechar postos de gasolina é uma questão de autoridade... a questão de combater o crume... eh... combater o crime... o Cidade Limpa é também um projeto que limpou a cidade e não teve custo... portanto... o que eu posso... dizer a você Marta... é que a população CONfia na minha administração... e ela sabe que não é verdade o que você está afirmando... É MENTIra... que eu vou implantar o pedágio urbano... infelizmente... eh... as mentiras tem que ser aqui desmentidas... então portanto... não é verdade... é mentira da ex-prefeita... esse projeto não existe... foi um eQUívOco... e ela está se valendo desse equívoco... aliás eu não tenho constrangimento nenhum quando 
há equívocos... teve vários na minha administração... eu no DIA seguinte voltei atrás... porque o prefeito...

L1: tempo... tempo candidato... quem pergunta agora é o candidato Gilberto Kassab...

L3: o telespectador... percebeu que o segundo turno é muito importante... porque é a oportunidade que ele tem... de relembrar como FOl a gestão da ex-prefeita... quando... ela aqui... lembra que encontrou uma cidade quebrada... nós encontramos tamBÉM... e nós tivemos capacidade para recuperar a cidade... e para va... para fazer investimentos MUlto expreSSIvos... EM TOdas as ÁREas... sem exceção... hoje a cidade está mais bem cuidada... está mais bonita... hoje os servidores estão confiando na administração... então até para que possamos ficar em TEmas... porque as proPOStas são muito importantes para aquele que está nos aSSIStindo... possa definir o seu voto... eu queria... aqui perguntar pra... candidata Marta... QUAis são as suas propostas para o VERde e o meio ambiente?

L2: olha... primeiro eu quero comeÇAR... falando dessa história de cidade quebrada... eu peguei a cidade quebrada de FAto::... foi REALMENte a SUA gesTÃO com O PITTA... me deixou a cidade com uma dívida giganTESCA... ou você não TÁ lemBRADO... dos precaTÓRIos... dessa cidade... que foram vendidos Títulos para paGAR os precaTóRlos... que/... e que depois esses Títulos eram TOdos FRIos... e que deixou tudo... pra/... PRA MIM.... quando fui eleita... PRA paGAR... voCE não esTÁ lembrado do Pas que voCÊ ajudou a CRlar... você não está lembrado... do CAos também... que tinha no transPORte?... o qu/... no final da gestão PITTA... NÓS tiNHAmos oito MIL vans clandesTINAS... enTÃO eu quero dizer que o que eu entreguei para vocês... é in-fi-ni-ta-men-te melhor do que eu recebi... eu entreguei uma cidade organiZADA... deu um salto giganTESCO criANDO a... o plano diretor para a ciDAde... um zoNEAMENto... trinta e uma subprefeituras que na MInha gesTÃO... quando eu cheGUEI... NÃO tiNHA UM comPUTADOR... entende?... vocês receBEram a cidade organiZAda... o Pas já tinha ido há QUAtro anos... já tinha o recurso do Sus... enTÃO... OLHA... tinha vinte e um Ceus criados... voCÊS... quando DIZ... que ah... é o orçamento... porque fiscalizamos... isso realmente pode melhorar um pouco porque eu deixei esse processo em andamento... mas a... a prefeitura melhorou... não foi por causa disso... foi por CAUSA do goVERno LU-LA... da maco/... da macro-economia desse PAÍS... que fez TODAS AS PREFEITURAS DESSE PAÍS... crescerem... enTÃO é BOM saber disso... se você tem dez Bllhões a MAIS por ano... NÃO é da GRANde CAPACldade de adminisTRAção... é da grande capacidade do Lula de fazer esse país crescer... ((vaias e aplausos))... em relação ao meio...

L1: eu pediria por gentileza à platéia que não se manifestasse... por favor... por favor... vamos manter a ordem e o debate vai muito bem... pediria QUE... MAIS uma VEZ... não se manifestassem...

L2: em RelaÇÃO à poLUIÇÃO... a coisa mais importante... o que MAIS POLUI... são os... os caRRos na ciDAde... então nós temos que melhorar o transporte PúBLIco... que foi o que eu FIZ... fazendo os corredores que você não fez nenhum... e ISSO que vai... que vai dar o grande passo... que as pessoas podem deixar o carro em casa e ir... eh:.... de ônibus...

L1: olha Boris... é impressioNANTE... mas eu não vou te questionar não... mas ela não resPONdeu sobre o verde e o meio ambiente... faLOU sobre a... necessidade da:: tirar os veículos da rua mas é transporte... mas eu quero lhe dizer Marta... em primeiro lugar que... você nessa campanha... mas... DIARIAmente você tem essa mania de trazer para a campanha o Lu::la... o Maluf... o Pitta... nós estamos 
discutindo aqui o futuro da ciDAde de São Paulo... o futuro de quem vai goVERNAR São Paulo... nós estamos aqui compaRANDO as propostas... até porque... se a cidade estivesse nessa situação que você afirma... Plor ainda a sua decisão de fazer TÚneis na região dos Jardins... gastando MAIS de DUZENtos e cinQUENta milhões de REais... para atender bairro de RIcos... que se a cidade estava quebrada... seria um:.... é realmente um descalabro... então eu quero dizer a você que realmente eu lamento muito mas eu VOLto aqui a questão do meio ambiente... SE é prioridade... por que é que você só construiu UM parque em sua gesTÃO?...

L2: bom... essa é uma mentira tão DESLAVADA que eu vou ficar aqui desmentindo o outro... vai ficar até ridículo... mas eu vou fazer isso daqui há pouco mas eu vou antes falar uma coisa que eu não tinha falado... eu acho muito importante saber com quem anda SIM... eu ando com o Lula... tenho muito orgulho... e você anda com Maluf e Pltta... e por que que você está envergonhado disso?... eu acho que as pessoas tem que saBER... ué?... a pessoa está ali ouvindo... hoje mesmo uma pessoa me falou... é verdade?... que ele foi secretário de planejamento do PItta?... eu falei... não só é verdade... mas ele administrava 0 orçamento da cidade... ELE que diz que eu fiz escola de LAta... foi ele que fez... entende?... essa é a verdade... então essa questão de trajeTÓria... é muito importante que seja dita e que você aSSUma a sua... por que não?... a minha não tem NEnhum problema em assumir... e a questão dos parques... nós fizemos MUlto PARques nessa cidade... OLHA... plantamos muita árvore nessa cidade... até o parque do... até o Parque do Povo... que você agora está inaugurando... que eu fico muito FELIZ... foi MUlto difícil passar todos os entraves buroCRÁticos... então tem certas coisas que são mais difíceis e que a gente conquista para a cidade... e nós conquistamos MUltas áreas verdes para a cidade...

L1: quem pergunta agora é a candidata Marta Suplicy...

L2: Kassab... na SUA propaGANda você diz que nenhuma criança ficaRÁ FOra de CREche... isso é NA SUA PROpaGANda... porque na SUA gestão não saBEMO/... nós sabemos o que o Alckmin colocou no último deBAte... que tem cento e dez MIL crianças FOra da esCOla... ah... os associações de defesa das crianças já pediram ao Ministério da JusTIÇA... para você dizer quantas tem de FAto... porque o dado de cento e dez mil que o Alckmin falou É de ABRIL... mas você ENGAna... NÃO MOStra o DAdo... só quer mostrar depois da eleição... na sua propaganda você DIZ que você vai elimiNAR QUALquer DÉfiCIT de VAga... TOdas VÃ̃O PAra a esCOLA... a FOLHA de SÃO PAUlo faLOU... se isso for verdade... com cento e dez MIL criANÇAS... você teria que consTRUIR... eh... uma escola a cada dois dias durante QUAtro A-NOS... então eu perGUNto para você que está em CAsa... em quem que a gente deve acrediTAR?... NO PRE-FEI-TO... REal... que deiXOU cento e dez mil crianças fora de escola... e que agora DIZ que vai fazer uma nova creche a cada dois Dlas OU... porque também não fez nesses quatro anos que esteve lá...

L3: olha Marta... em relação às companhias... você esqueCEU de dizer que quando eu fui secretário do planejamento... a secretaria não cuidava do orçamento e um dos meus colaboradores para fazer o plano diretor... que era a minha atribuiÇÃO... foi seu ex-secretário do planejamento Jorge Wilheim... aliás uma pessoa honrada... eu queria também lembrar... que o Maluf... ele esteve com VOcê há quatro anos atrás... e hoje... é da base... é da base do Lula... base de governo do Lula... ((aplausos))... e em relação ao Pitta... em relação ao Pitta... 
L1:

mais uma vez...

L3: eu... eu...

por gentileza... por gentileza...

L3: eu assim como quatro milhões de

eleitores... me arrependi e me afastei DEle... eu queria dizer portanto que... as minhas companhias eu tenho muito orgulho delas... é o governador JoSÉ seRRA... é o vice-governador Alberto GOLDman... secretário LUna... secretário JanuÁRIO... secretário ManueLITO... secretário Clóvis CarvVALHO... secretário Andrea MataRAZZO... Guilherme Affif Domingos... Jorge BornHAUSEN... são pessoas que eu tenho MUlto orgulho de caminhar... eu queria dizer a você Marta... que... em relação aos parques... você entregou um único parque sim na cidade de São Paulo... está aqui o secretário Eduardo Jorge e... a sua equipe para me confirmar durante a seMAna... portanto eu estou muito tranquilo em relação a isso... e quanto às vagas nas creches... você esqueCEu também de mencionar que eu fiz QUARENta e cinco MIL vaGAS... criei QUARENta mil vagas... você criou dez mil... e QUEM faz quarenta mil vagas e agora está dando prioridade para esse tema para a próxima gestão... É eviDENte... que vai eliminar o problema de vagas em creche na cidade de São Paulo... esse é um compromisso... assim como era um compromisso acabar com as SAlas de lata... com as esCOlas de lata... e nós acabamos... e na próxima gestão... o compromisso ZEro nosso... será... resolver o problema de faltas de vagas em creche...

L2: bom a mentira continua... é deslavada em relação ao número de crê/... de vagas... e DESlaVAda em reLAção às vagas de creches... porque ele não vai poder fazer o que está prometendo... mas eu vou voltar a poLíTlca... porque quando você diz que trabalhou... não era no orçamento... É SIM... porque o secreTÁrio de planejamento da gestão do Pltta... trabaLHAVA com o orçaMENTO... de finanças... que era o Freitas... que emitiu os precatórios na gestão do MaLUF... era o seu colega e vocês dois trabalhavam juntos... então é muito fácil agora dizer... não fui... não fiz... não $F I Z$... não aconteCEU... ACONteceu SIM... e MAIS... quando o Pitta estava send/... quase sendo processado pelo... tinha aquele moviMENTO para processar... e fazer 0 impeachment do PItta... QUEM liderou o movimento REAge Pitta?... foi voCÊ... REAge PItta... ali já se sabia dos precaTórios... tanto é que todo mundo quer TIrar o Pitta do governo... voce foi... quem foi o CARRO-chefe... de Reage PItta... chamando ele de hoNESTO... etc.... etc.... quanto às creches... olha... eu FU/... construí CREches... você conveniou... fizemos a mesma quantidade... quarenta e três... quarenta e cinco mil os dois...

L3: viche Maria!... ((risos))... é impressionante... MAS o eleitor... ele é bem inforMAdo... ele sabe se informar... ele sabe quantas vagas em creche fizemos... ele sabe que a secretaria de finanças é que tinha orçamento... ele sabe que eu me afastei do Pitta... enfim... ele sabe a verdade... portanto... esse debate aqui é para debater propostas... eh:.... é em cima de propostas que eu vou ficar... NAda vai desviar a atenção da nossa candidatura... porque o eleitor... ele hoje está muito maduro... o eleitor quer conhecer e avaliar a gestão e avaliar as propostas... AVAliar as companhias... as equipes... e tem sido muito gratificante o carinho que eu tenho sido... recebido nas ruas... as últimas pesquisas... o Datafolha... por exemplo... eh... um instituto de muita credibilidade... acabou de... nos dar um número MUlto expressivo de seSSENta e um por cento de aprovação... na sua 
fase foi... no seu governo... nessa época... era quarenta e oito... do JElto que a candidata Marta fala parece até que a população não está aprovando o meu governo e APROvou o dela... ela foi REPROvada... tanto é que não se reeleGEU... mas eu vou continuar apresentando propostas e va/... falando sempre... A... VERDAde...

L1: quem pergunta agora é o candidato... GILberto Kassab...

L3: eu tenho dito... em todos os momentos... que o segundo turno é muito importante para que... com MAIS profundidade... os eleitores conNHEçam... as realizações da administraÇÃO... as propostas dos candiDATOS... e eu quero contiNUAR... eh:.... FORTAlecendo os debates para que a gente ganhe qualidade nessa campanha... então... ao LONgo da campanha... eu tive oportunidade de esclarecer a imporTÂNCIA que teve para a cidade de São Paulo... para o nosso ORçamento... o combate as fraudes nas cra/... catracas... eu queRIA... eh:.... pergunTAR... a ex-prefeita... até porQUE... quando NÓS combatemos essa fraude... nós criamos MILHAres de postos de atendimento do bilhete único para que ele fosse recarregado... e hoje a população... ela está saTISfeita... ela tem onde recarregar... eu queria que ela explicAsse um pouco se ela vai efetivamente permitir a volta da fraude nas catracas...

L2: olha Kassad... Kassab... primeiro eu ainda vou voltar à questão da creche... você não falou a verdade e eu quero deixar isso claro... e você que tem Fllho e procura no serviço público uma creche... SAbe quem está falando a verdade em relação a essa questão... eu vou SIM... e vai ser no primeiro... no segundo dia... recarregar o bilhete na catraca... por que que eu vou fazer isso?... porque você faz uma coisa muito perversa... você tirou um beneFÍCIO da população... dizendo que havia fraude... se havia fraude... controle melhor... não tire o benefício da população... a população PObre dessa cidade muitas vezes não TEM 0 diNHEIRO para comprar o bilhe... o... para recarreGAR... numa loTÉRICA... tudo... então ela tem aquele dinheiro COM-TA-dinho... que ela vai e recarrega NAquele DIA... e com o que você FEZ... você fez muitas pessoas pagarem ali... não poder valer o bilhete único... elas tem que descer do ônibus... porque já não VAle... e fazer o segundo... o segundo percurso a PÉ. ALÉM disso tem as pessoas que ATÉ teriam o dinheiro... hoje está no jornal... uma... uma questão sobre essa... uma comparação de gestão e composição de pessoas... mosTRANdo uma moça que disse que tem que fazer Flla... se não me engano ATÉ em HigieNÓPOLIS... que é um bairro rico... de classe média alta... dizendo que tem que fazer fila porque não consegue recarregar o bilhete na catra... na catraca... então são VÁRlas as quesTÕES sobre esse assunto que me TOcaram o coração... porque eu PENso nas pessoas... ao conTRÁrio de você... que parece pensar SÓ na FRAUde... a fraude a gente tem que controlar... mas as pessoas vem SEMpre em primeiro lugar... não vou penalizar o povo pobre da nossa cidade... incluSlve... você fez a extensão do bilhete para três horas... mas você é EXATAmente desse jeito... finge que faz... porque aumentou para três HOras... só que você que está em casa... que não usa o vale-transporte... ou não usa o vale-estuDANTE... você não SAbe que ele não ampliou para essas... para essas categorias... é só para quem usa de vez em quando o biLHEte... vale-transporte não VAle... né?... e ele também TIrou... o direito de fazer mais do que quatro VIAgens... que isso é muito pouco em dinheiro para a prefeitura... e as pessoas pobres necessitam disso...

L3: em primeiro lugar eu não direi... não tirei o direito de fazer mais do que quatro trechos... BASta a pessoa se cadastrar e já tem doze mil pessoas cadastradas... ((murmúrios))... em relação ao comBATE... em relação ao combate à fraude... ela usou o termo controlar a fraude... eu não controlo... comBAto mesmo... combati a fraude da gasolina adulteRADA e combati a FRAUde nas catracas... e GRAças a 
esse combate... nós pudemos... telespectador... aumentar o tempo do bilheteúnico de duas horas para três horas... implanTAR... aos doMINgos... o bilheteamigão... fazendo o/... bilhete-único valer Olto horas... GRAças ao combate à fraude... nós estamos há DOis anos sem aumentar a passagem de ônibus de São Paulo... e já temos o compromisso de ficar mais um ano... o ano que vem... portanto... é beneFÍcio para o trabalhador... é benefício para o trabalhador que respeita a lei e que não FRAUda... portanto eu vou SIM combater as fraudes porque isso é fazer jusTIÇA SOcial... eu queria perguntar...

L2: não... não...

L3: é só que encerrou e eu queria perguntar e... não tinha acabado o tempo lá... eu queria perguntar ainda...

L2: não...

L3: ...a candidata Marta... o por que ela enterrou os duzentos milhões do fura-fila e deix... a obra continuou parada...

L2: olha... eu vou dizer para você que esse aumento... que você diz que foi uma bonDAde... para as três horas... porque economiZOU... não é verdade... você aumentou para três horas agora... pertinho da eleição... o povo que está ai sabe... podia ter feito isso antes... sabe por QUÊ?... porque você deixou ficar o CAos no transporte... na hora que ficou o CAos no transporte... o trânsito ficou prejudiCAdo... e os CORREdores que nós deixamos funcioNANdo MUlto BEM... e que eram RÁpidos para a populaÇÃO... e até gente que andava de automóvel paSSOU a andar por alguns correDORES... não estavam funcionando mais... por quê?... porque você deixou entrar ÔNIbus clandesTInos... deixou entrar ônibus intermuniciPAIS... meTAde... MAIS da meTAde eu soube... dos radares não estão funcioNANdo... então entram carros que não podem enTRAR... enTÃO... essa incapaCldade de GEStão... é que fez com/... que voCÊ ampliASSE as horas do corredor... ALÉM de ser uma coisa eleitoreira também... porque a gente não SAbe o que você vai fazer... prefeito real... quando essa eleição termiNAR... porque é sempre uma indagaÇÃO...

L1: no próximo bloco jornalistas do grupo Band fazem perguntas aos candidatos... ((aplausos))... eleições dois mil e oito... debate... você decide na Band...

((vinheta de intervalo))

L1: e voltamos ao PRImeiro debate do seGUNdo turno entre os CANdidatos à PREfeitura de SÃO Paulo... participam deste BLOco os jornalistas da BANd... Fernando Vieira de MEllo... e José Paulo de Andrade... vamos às regras... jornalistas da BANd perguntam aos candidatos... resposta de DOis minutos... comentários e réplicas de um minuto CAda...

L4: candidato Gilberto Kassab boa noite...

L3: boa noite...

L4: tem uma questão que não pode ficar de fora desse debate que é a crise global... vários países estão sendo atingidos por ela... inclusive o Brasil... e há um consenso aqui no Brasil de que haverá recessão e o Brasil não CRESce... MAis do que cresCEU em dois mil e oito... eu lhe pergunto... quando o senhor fala em orçamento de mais de vinte e nove Bllhões de reais... o senhor não está fugindo da realidade?...

L3: não Fernando... se há algo que marcou a nossa gestão... foi o cuiDAdo na administração dos recursos... e a compatibilização... das despesas... com as receitas... nós manTIVEmos um nível de crescimento nos últimos dois anos que nos permitiu elaborar essa peça orçamentária encaminhada para a Câmara Municipal... por outro lado... se... tem UMA virtude em nosso goVERno... foi justamente termos a certeza absoluta que os inVESTImentos prioritários precisariam ter planejamento... planejamento nos investimentos na saúde... na 
educaÇÃO... no combate à poluiÇÃO... e eu tenho MUlta tranquilidade em dizer a você... que a cidade está preparada para enfrentar uma situação adversa... que a nossa administração... está preparada para continuar PLAnejando de uma maneira muito adequada... mesmo enfrentando uma eventual crise internacional que... infelizmente... a tendência é que se aprofunde... MAS São Paulo... além do mais... é uma cidade voltada à serviços... e a crise num primeiro momento... ela irá afetar a inDÚStria... e eu tenho muita tranquilidade de dizer para você que essa peça... ela foi... com muito bom senso elaboRAda... que estamos preparRAdos... diferentemente da candidata Marta... que nos CRItica por termos recursos em caixa para pagarmos as despesas já realizAdas... nós vamos continuar... adotando... essa política de administração de... dos recursos... para que a gente possa transmitir tranquilidade à cidade de São Paulo... a cidade está nas mãos de uma administração MUlto cuidadosa... e seremos MAis cui/... cuidadosos ainda... na administração dos recursos com a crise... posso lhe tranquilizar e tranquilizar os telespectadores... estamos preparados sim... temos recursos em caixas para enfeitar... enfrentar TOdas as despesas e... para dar sequência à um planejamento MUlto BEM... eh:.... elaboRAdo...

L2: bem... o que eu quero dizer é que eu acredito no presidente LUla... que está tomando as medidas neceSSÁrias... e QUE a crise chegará no Brasil... vai respingar com certeza... mas isso a gente espera que não na dimenSÃO como algumas pessoas acham que poderá ocorrer... mas SE ocoRRER... e a ciDAde de São PAUlo tiver que ser administrada com menos... eu já provei... eu já provei que eu sei administrar com MUlto menos... administrei a cidade quando ela tinha um orçamento de QUINze bilhões... o Brasil ia com MUlta dificuldade... o país estava tomado... ainda... pela... toda a dificuldade do final do governo Fernando Henrique... um começo muito diFícil... porTANto... do Lula e nós soubemos administrar... e conserTAR o transporte da ciDAde... fazer ele funcionar direito... fazer vinte e um Ceus com TÃO pouco... e administrar muito bem... agora essa história de dizer que deixou dinheiro no banco... porque é muito bom para a CRlse... não... não acredite nisso... deixou dinheiro no bando... dois bilhões e meio no primeiro ano e três bilhões e meio no segundo...três bilhões no quarto... e agora QUAtro bilhões e POUco... porque não PLAnejam e deixam o dinheiro no mercado financeiro...

L3: para que o telespectador possa compreender o que a candidata fala... em uma maneira mais simples... ela diz o seguinte... você que paga aluguel... você que tem despesas na escola de seu filho... não precisa ter conta... ter dinheiro em conta não porque... use o cheque especial... é isso o que ela quer dizer... a cidade de São Paulo... uma cidade com ONze milhões de habitantes... uma prefeitura que tem responsabilidades... que tem compromissos... precisa ter recursos em caixa para não quebrar... como aliás estava quebrada no final da gestão Marta... REcuperamos a cidade... e essa recuperação que faz que a gente poder vir a público para afirmar que estamos tranquilo... a administração não sofrerá interferências com a crise internacional... porque estamos nos preparando para isso... com a austeriDAde que tivemos no uso do recurso público...

L1: agora o jornalista Fernando Vieira de Mello pergunta a candidata MARta Suplicy...

L4: boa noite candidata Marta Suplicy...

L2: boa noite...

L4: apesar dos investimentos peSAdos que foram feitos nos últimos anos com a construção de vários Ceus... o ensino municipal de São Paulo foi REproVAdo em dois mil e sete... com nota abaixo de cinco... no Índice de Desenvolvimento da 
Educação BÁsica... o FOco não está errado?... além de construir a prefeitura não deveria investir peSAdo no treinamento de professores?...

L2: olha... desculpa Fernando... mas ele falou uma coisa que eu quero/... que eu quero comentar antes... ele disse que o:.... a família paga suas contas e tal... e deixa o dinheiro guardado... nós não estamos falando disso... nós estamos falando de uma família que... muitas vezes não vai comprar uma comida ou não vai comprar um tênis para deixar o dinheiro economizado... isso não existe... né?... a gente cuida primeiro das necessidades... e foi o que você não fez... né?... você deixou dinheiro no banco... faltando creche... faltando corredor de ônibus... faltando TANta coisa na cidade... agora... Da questão da educaÇÃO... eu quero dizer o seguinte... a... a... a qualidade está muito RUim na cidade... isso é verDAde... nós vamos ter que investir primeiro na condição de trabalho do PROFEssor... para que ele possa dar aula... numa MESma escola com um salário meLHOR... e depois nós vamos ter que fazer cursos de FORMAção CONTINUada... pro/... professor... não adianta exigir do professor que ele dê uma aula melhor... ele se formou no magistério... numa faculdade que muitas vezes não Ihe formou como deveria... e ele também... muitas vezes está há muito tempo na... na... dando aula... então ele PREClsa... realmente... ter uma re... uma recuperação nessa formação... nós vamos logo... no primeiro dia de aula... COMEçar a ver CAda cole... cada esCOLA... qual é a sua necessiDAde... fazer as suas metas... e fazer esse curso de formação continuADA para que os professores possam ser ensinados... de aCORdo com o que ELE que... SER ensinado... que ELE percebe NEle... que é a sua dificuldade de ensino... que pode ser em muitas áreas diferentes... e então eu vou investir MUlto no professor... além de fazer a REde Ceu... que é um conceito... que a administração Kassab NÃO entendeu... que é você dar CULTUra e dar LAZER para a criança que não tem... então a criança que estuda numa escola municiPAL... ela poder... ser leVAda... de Vai e Volta... que você cortou pela metade... né?... ela ser levada de Vai e Volta a um Centro Esportivo das prefeiTUra... que ela possa também ir a uma orquestra... assistir coisas bonitas que a prefeitura possa oferecer... ela tem direito e eu vou fazer...

L3: em relação ao Vai e Volta eu mantive o mesmo número de alunos... com carros novos... e evidente que hoje menos alunos precisariam porque... estamos construindo duzentas e dezessete novas escolas... quero dizer a:.... candidata Marta que o meu competente secretário da educação deve ter ficado... o Alexandre Schneider... que está aqui... ruborizado com a afirmação sua... que precisa investir em professores... em servidores... em capacitação... NÓs fizemos isso... os professores e servidores em educação... sabe disso... nós implantamos o programa Ler e Escrever... que reduziu o índice de analfabetismo que era TRINta E CINco por cento no final do segundo ano... e hoje é Oltenta e CINco por cento das crianças que conseguem sair LENdo e escrevendo no segundo ano... uma mudança radical... programas de capacitação foram implantados... então o Fernando tem toda a razão... precisa investir sim na qualidade do servidor... na qualidade do ensino... é isso que nós estamos fazendo... a ex-prefeita fez vinte e um Ceus e errou... porque ela tinha que ter começado investindo nos servidores... nos professores... e eliminado as salas... as escolas de lata... isso que nós fizemos... ((aplausos))

L2: olha eu...

L1: $\quad$ por favor... senhores...

L2: vou dizer... 
L1: mais uma vez eu peço encarecidamente que a plateia NÃO se manifeste... MAIS uma vez... POR gentileza...

L2: mentira de novo... você falou uma mentira do Vai e Volta... são... eu deixei... CENto e quatorze MIL... e você hoje fornece para cento/... pra setenta e um MIL... não adianta mentir... isso está publicado... pode oLHAR... ao mesmo tempo... e não é... agora ainda vem com essa história porque construiu muita escola perto... olha... é... é... eu fico PASma com isso... ao mesmo tempo você não ofereCEu magisTÉrio pra... pro pessoal de CREche... você não ofereCEu curso universiTÁrio para o pessoal da... da... que dá aula... que eu fiz na nossa gestão... formamos na universidade mais de três mil e quinhentos professores... então nós vamos investir PRA VAler... SIM... na educação... porque... quando você cria um Ceu já é com esse conceito... e agora você acabou de dar uma escorregada... quando você disse que eu tinha... não tinha que ter feito o Ceu... ué?... eu NÃO SÓ fiz os vinte e um Ceus... COmo... comecei a tirar as escolas de LAta que VOcê CRlou... e que eu comecei a tirar e deixei TOdas contratadas para você... e essa é a verdade...

L1: senhor Kassab... o senhor está pedindo réplica?...

L3: não... ela pela terceira vez... ela disse que eu menti...

L1: não... não...

L2:

não... não...

não...

[

L1: $\quad$ um

instantinho por gentileza... se o senhor quer direito de resposta... tem que conSULtar...

L3:

eu sei

disso...

[

L1:

nossa equipe de juristas... então ah... em seguida... no final do bloco... ou no... no começo do PRóximo bloco... nós teremos a resposta... da nossa equipe de juristas... se o senhor tem ou não direito...

L3: $\quad$ perfeito...

L1: $\quad$ de resposta... eu vou passar a palavra agora... ao... jornalista José Paulo de Andrade... que perGUNta ao candidato Kassab...

L5: candidato Kassab... sobre transporte coletivo o senhor diz que faz dois anos que a passagem não sobe... e que vai passar mais um ano sem subir... quer dizer que ela subiu BEM antes disso?... qual é o CUSto do transporte coletivo para o contribuinte de São Paulo?...

L3: o José Paulo... na cidade de São Paulo... como em qualquer cidade do mundo... o CUSto do transporte público ou é do passageiro... ou do poder público... GRAças a uma eficiente política de administração dos recursos da cidade de São Paulo... nós estamos podendo... combatendo as fraudes... administrando corretamente esses recursos... não aumentar a passagem de 
ônibus... novembro... já vai fazer DOis anos que não damos aumento para a passagem... implantamos o amiGÃO... que é o uso do bilhete oito horas nos domingos... implantamos o aumento do tempo do bilhete durante a semana... para três horas... então ISSO nos permitiu afirMAR... e isso será cumprido... que ficaremos MAis um ano sem aumentar a passagem de ônibus... é por conta do uso correto do recurso público... nós estamos PRIORIzando recursos do tesouro... até porque o contrato... aliás feito pela ex-prefeita na sua gestão... eh... o contrato EXISte... nós remuneramos PElo contrato as empresas... e SUBSIdiamos... para não aumentar a passagem... com recursos do teSOUro essa passagem... e VAmos SIM ficar o ano que vem sem aumentar o preço da passagem...

L2: bom... o:.... recurso público que eu vi no novo orçamento... ele vai... aumenta o subsídio bastante fortemente... né?... então não é por economizar aqui ou ali que ou tal... é porque vai ser subsidiADO... eu quero me comprometer aqui a não aumenTAR a passagem em dois mil e nove... porque eu vi que já criaram uma BOA/... boataria... assim como que eu vou aumenTAR a passagem... eu vou fazer taxa... eu quero também recuperar AQUI e dizer... EU NÃO VOU FAzer taxa de NAda mais nessa cidade... NAda ((risos))... então isso eu quero deixar como comproMISSO com você... agora... o MAIS importante no transporte público... além de um passa/... uma paSSAgem barata... que não TÁ... mas além de uma passagem com preço... vamos dizer... poSSÍVEL... é você ter agilidade e ir confortável... e isso eu cheguei... olha... PERTO na nossa administração... nós fizemo/... mudamos para NOve mil ônibus NOvos... nessa cidade... e essa gestão... essa gestão abandonou o transporte... o trânsito que está é decorrência da falta de investiMENto na Cet... é decorrência na falta de investimento no correDORe no metrô... que diz que vai dar um cheque de um bilhão...

[1:

tempo...

[

L2:

mas não deixou...

L3: bom... eu queria dizer que já demos duzentos e setenta milhões para o metrô... essa semana estamos dando mais... teremos uma solenidade com o governador José Serra... até o final do ano será um bilhão de reais... posso lhe dizer que é IMPRESSIonante falar da Cet... encontramos a Cet com uma dívida de CEM milhões de reais... SEM veículos... totalMENte sucateADA... aliÁS... e... está à disposição da imprensa a partir de amanhã... a nossa assessoria pode colocar a disposição da imprensa... ela ia acabar com a Cet... ela mesma deu entrevista dizendo que ia acabar com a Cet... e vem aqui dizendo investIR na Cet... é realmente... nós precisamos falar a verdade aqui... para que as pessoas SAlbam quais FOram as realizações da ex-preFEITA e quais são as propostas da candidata... nós VAmos sim continuar investindo no transporte PÚBLIco... vamos investir no Rodoanel... tem trezentos milhões no orçamento para o investimento no Rodoanel... vamos investir mais UM BIIhão de reais na próxima gestão no metrô... e VAmos fazer corredor de ônibus como deve ser feito... dessa maneira... José Paulo... nós vamos... melhoRAR de uma maneira muito significativa... a qualidade do transporte público...

L2: bom... além de fazer uma propaganda que é enganosa... 
L1:

candidata... ((vozes))... terminou... terminou...

ора... ора... ора...

L2: ah... desculpa... eu não falo mais...

L1: combinou... não... a senhora fala... não agora... o candidato KaSSAB havia pedido direito de RESPOsta... nós consultamos os juristas que estão aqui na BAnd e a resposta é positiva... o senhor tem UM minuto... ((aplausos))...

L2: não... não... não... eu sei... ele está pedindo direito... peraí... ele pediu direito de resposta... L3: ah... Ó Boris... quando eu falei mentirosa... ele me chamou... ele me chamou... ((manifestações da plateia))...

L1:<smiles>[3H]</smiles>

está pedindo direito de resposta... se a senhora... a senhora... a senhora... com licença... com licença... a senhora está pedindo direito de resposta também?... então tamBÉM o seu direito de resposta fica a consideração da nossa bancada de juristas...

L2: eu vou dizer por que Boris...

L1: não... não... não precisa dizer o porque... é o seu direito... é o seu direito... é o seu direito de pedir... e a senhora... esse direito está sendo agora analisado... o senhor tem UM minuto para exercer o seu direito de resposta...

L3: a candidata Marta... ela faz um debate pequeno... até mesquinho ao longo dessa campanha... e também hoje nesse debate... talvez seja o desespero pelas pesquisas... é impressionante... ela aqui vem falar em compaNHlas... e esquece de mencionar... se for para levar para esse campo... que ela está... ao lado do Delúbio... que tem a sua esPOSA... o Delúbio que foi o grande CENtro do escama/... do esquema do MenSAlão... e que a ESPOsa do DeLÚbio... foi a sua principal asseSSORA... e continua sendo... ela esQUEce de falar que companheiro seu... do escan/... do esquema do dólar na cueca... esTÃo na sua camPAnha... portanto... é impressioNANte... quer dizer... isso... e ainda vem aqui agredir... dizendo que a gente MENte... isso não pode... o eleitor quer um nível eleVAdo... o eleitor quer proPoStas... portanto eu aqui... faço esse conVlte à candiDAta... vamos manter o Nível... nesse debate... nessa campanha... para respeiTAR o eleitor... é ISSO que SÃO Paulo QUER... ((murmúrios e aplausos))...

L1: eu queria... eu queria... informar à candidata Marta SupliCY:: que o seu pedido de direito de resposta foi NEgado... ((murmúrios e aplausos))... vamos agora... candidata... candidata... estamos respeitando as regras do debate...

L2:<smiles>[TeH]</smiles>

L1:

candidat/... estamos respeitando as regras do debate... ((murmúrios))... se a senhora fizer OUtro pedido...

L2:

eu estou fazendo outro

pedido... 
L1:

está fazendo um NOvo pedido e eu peço mais uma vez a consideração da nossa bancada de juRIStas e passo a palavra ao jornalista José Paulo de AnDRADE que vai fazer a pergunta à candidata Marta Suplicy...

L5: candidata Marta... a senhora tem se referido ao prefeito Kassab dizendo que ele não tem iMAgem própria... mas quinta-feira onze ministros do governo Lula... com pouca intimidade com a cidade de São Paulo estiveram aqui... para dar apoio à senhora... e na SEXta-feira... o presidente Lula... MAIS uma vez... ele participou do primeiro turno e esteve numa reunião com evanGÉlicos eh:.... não foi lá muito positiva... foi constrangedora ATÉ... em determinado momento... eu pergunto... e a sua iMAgem?... NÃO é suficiente para a senhora pedir VOto... pra/... pro povo de São Paulo?...

L2: são duas coisas bem diferentes... quando eu digo que ele não tem imagem própria... é uma pessoa que as pessoas não coNHEcem... é uma pessoa/... é uma pessoa que as pessoas não sabem que trabalhou com o Pltta... é uma pessoa que as pessoas não sabem que liderou o movimento REAge Pitta... então ESSA trajetória desse candidato... o seu PARtido... O P- F-L... o que simboliza... 0 Dem... que é o Pfl que mudou de NOme... que foi EXTInto agora... na:.... em todas as capitais do nordeste e do norte... a única COlsa que sobrou pro/... pra esse partido... o Pfl-Dem... é essa disputa da prefeitura de São Paulo... então isso tudo as pessoas desconhecem... e eu acho importante que elas conheçam... agora... a VINda dos/ ministros aqui... não é que eles não são familiarizados... alguns são da cidade... outros não são... mas quando você é ministro... e eu fui ministra... José Paulo... você conhece muito BEM os problemas da maioria das cidades... e DA cidade de São Paulo... que é a maior cidade do BraSIL... ali qualquer ministro pode dar aula... o que eles vieram diZER... é que eles são parCEIros... porque nós TEmos os MESmos interesses em ajudar essa cidade a se desenvolver... e tão parceiros... que eu não devolveRIA o recurSO que o presidente Lula mandou para as ambuLÂNcias... e que... o... o... prefeito KaSSAB deixou os trinta milhões usando só um pouquinho... mas deixou lá tanto tempo que a mesma quantia que veio é a que está no banco... e também não devolveria os quinze milhões que ele devolveu... do Pró... do Pró-Jovem... que era para qualificar trinta mil jovens... e ele qualificou dez mil e devolveu 0 dinheiro... então esses ministros... eles sabem que trabalhar comigo... é diferente... José Paulo... é diferente... porque nós temos os mesmos objetivos... nós queremos alavancar a cidade como um todo... queremos esse Brasil crescendo... queremos a união de todos os paulistanos pruma cidade mais JUSta... mais fraTERna... mais igualiTÁria... é para isso que nós lutamos... é por isso que a gente está juntos... ((aplausos))...

L3: José Paulo... a campanha da... candidata Marta... fica parada quando ela diz que a cidade não me conhece... seSSENta e um por cento da cidade entende que a minha administração é ótima-boa... nas eleições do primeiro turno agora... eu fui MUlto bem votado... e agradeço aqui os votos a todos os paulistanos... todos os telespectadores... então... portanto... a cidade me conhece... eu estou MUlto feliz com o carinho que eu tenho recebido... com que eu tenho sido recebido aqui na cidade... nessa campanha... e eu queria dizer que em relação ao Samu... esses recursos que estão rendendo juros... parados na conta bancária... foi fruto... foram frutos de um entendimento com o governo federal... nós temos hoje CENto e VINte ambulâncias em $a m / . .$. em operação... comprados com recursos do tesouro... o dobro da sua gestão... mais quaRENTA de reserva técnica... e esses recursos... conforme publicado ediTAL... nos últimos dias... sua assessoria não the inforMOU... SERvirão... e es... e o edital publicado já... para investimentos em 
tecnologia pra comunicação dos equipamentos... portanto... eu tenho MUlto orgulho do que a cidade pensa a meu respeito... da minha administração... e tenho muito orgulho de minha equipe financeira que usa com MUlto rigor os recursos públicos...

L2: bom... eu quero dizer que o seu:.... marqueteiro... está realmente de parabéns... porque fez uma propaGANda que as pessoas puderam ter uma iDEia do Kassab da propaganda... aquele que promete coisas que o Kassab PREfeito não faz... agora... não VÍ na sua propaganda falar da sua trajetória... e as pessoas não COnhecem... as pessoas... a maioria... não sabem que você é do partido Dem... você aparece travestido de tucano... tenta engaNAR a pop/... a população... se dizendo um tucano... a/ pessoas não sabem... né?... agora... você pertence SIM... e é o líder que sobrou do PfI no BRAsil... ((murmúrios))... é quem vai capiTA-Near... ((murmúrios))... é quem ESTÁ capitaNEANdo uma...

L1: por favor...

senhores...

[

L2:

o partido em extinção... o parTIdo dos coroNÉis do norDESte... o parTldo que foi o aTRAso no nordeste... você... que é do nordeste... ou tem familiar LÁ... você sabe o que era o nordeste antes do governo LUla... que foi quem levou Luz para Todos... o Bolsa Família e fez crescer a economia... ele é do partido que deixou...

L1:

tempo...

L2:

o nordeste daquele jeito...

L1: eu queria inforMAR... no final deste bloco... que... consultada a comissão de juristas... o seu segundo pedido de resposta foi neGAdo... e queria ressaltar que o pedido de resposta deve ser feito apenas quando... e no momento... que 0 candidato se sentir PESSOalmente ofendido... no próximo bloco... a última rodada de perguntas entre candidatos... ((aplausos))... eleições dois mil e oito... debate... você decide na Band...

((vinheta de intervalo comercial))

L1: e voltamos com o deBAte com os candiDAtos à prefeitura de São Paulo... conosco nesse transmissão estão a BAnd News Tv... e as rádios BANdeirantes Am e Fm... e a BAnd News Fm... você também pode acompanhar o debate pela INternet... vamos às regras deste QUARto bloco... CANdidato pergunta para CANdidato... a ordem aqui se inverte em relação ao segundo bloco... pergunta de UM minuto... DOis minutos para a resposta... réplica e tréplica em UM minuto CAda... o primeiro a perGUNtar é o candidato GILberto Kassab...

L2: eu queria perguntar à candidata Marta... quais são as suas propostas em relação à... MAnutenção da secretaria... municipal que cuida dos problemas... das pessoas que tem defiCIÊNCIA... eh:..... e... mobilidade reduzida... nós tivemos uma SÉrie de avanços na nossa cidade... ao longo de nossa gestão... um tema MUlto importante... DEZ por cento das pessoas hoje... são Vítima de uma deficiência de mobilidade reduzida... e portanto eu queria conhecer as suas propostas...

L3: eu acredito que é muito importante essa secretaria... nós... na nossa gestão não fizemos uma secreTAria... mas cuidamos com muito cuidado... porque mesmo (pegando) uma cidade destroçada e precisando investimento em tudo... nós investimos MUlto... no CENtro da cidade principalmente... foi o escoLHIdo para comeÇAR... nas calçadas... que permitiam as pessoas... eh..... cadeirantes... 
poder se locomover melhor... eu aque... depois também nos ônibus... eu acho que nós poderíamos ampliar e MUlto... nos ônibus... para os cadeirantes que ainda é muito deficiTÁrio... eu iria além disso também... porque não é só esse tipo de portador de problema... mas é o Atende... que vocês não aumenTARAM... e eu ando agora... to/... conversando com a população... com MUlta reclamação da população... que geralmente só consegue se... se trans... se transportar com 0 Atende... o Atende não mais está ali dispoNível para as pessoas... e eu tenho uma proposta também... que É a partir de... de uma coisa pessoal de percepÇÃO... e que agora a prefeitura tem MUlto mais recursos... dez bilhões a mais todo ano dá para fazer... coisas que eu sonhei e não pude faZER... de nós fazermos CENtros... para as pessoas que tem algum tipo de comprometimento e que a família também não consegue cuiDAR... e que eles teriam... poderiam ficar durante o DIA... para serem cuidados... e a família... aquela pessoa que TÁ em casa tomando conta... poder ter o seu trabalho... e o seu ente querido estar cuidad o num centro... que eu não chamaria de recuperação... mas seria desse tipo... ao mesmo tempo também... classes especiais... isso... essa semana... uma senhora me parou na rua que tem um filho de vinte anos... que não conseguiu aprender a ler e a escreVER... ele não pode ir para uma escola de criança... o que fazer... faltam também luGAres para ajudar e abrigar essas... essas mães que CUIdam desses... desses aDULtos... mas que tem problemas... aí de... de... Qi... de comprometimento... então MUlta coisa para FAzer... e com mais dinheiro CERtamente poderemos fazer...

L3: bom... eu queria lembrar a candidata Marta que na sua gestão eram CENto e vinte e quatro veículos do Atende e hoje são DUzentos e setenta e três... atendendo o DObro de usuários na cidade de São Paulo... em relação ÀS calçadas... nós... ao longo desses quatro anos... nós reformamos TREzentos e cinquenta quilômetros de calçadas... todas elas com total acessibilidade... também queria... lembrar aqui... a ex-prefeita... a questão dos ônibus... na sua gestão... ela::... foi responsável pela adaptação de treZENtos ônibus para deficientes... na nossa gestão esse número subiu para DOis mil e oitocentos... eu queria aqui indagar da:.... candidata Marta... por que na sua gestão... quando da reforma das calçadas e do rebaixamento das GUlas... ela não fez RAMpas de acesso para os cadeirantes... só fez trinta e duas rampas... no bairro do Itaim Bibi... e essa é uma necessidade FUNdamental para o cadeiRANte... que ela explicasse por que não priorizar o cadeirante com as RAMpas que foram feitas em...

L2: eu acho que...

[

L3:

apenas na região ( )...

L2: as rampas tem que ser feitas... e eu acho que nós podemos fazê-las... e eu acho que tem que ser na cidade inteira... não é uma questão de ser CONtra... é uma questão de com QUANto eu trabalhava... em recursos... eu tinha dez bilhões a menos que você... tinha que consertar o caos do trânsito que você deixou... tinha que lidar com a saÚde... que estava no Pas... que foi você que criou... então tinha uma série de dificulDAdes... que eu tinha que atenDER... mas AO MESmo tempo... você mesmo DIZ... Kassab... eu comecei a fazer... eu não deixei isso abandonado porque eu não tinha dinheiro... eu enFRENtei TOdos os problemas JUNtos... e era MUlto problema nessa cidade... e tem uma coisa que eu quero dizer que eu vou auMENtar... porque eu acho muito importante... tenho ouvido muitos idosos falar... que é o acompanhante... que eu chamava de Anjos Urbanos... vocês mudaram o nome para acompanhante... que é a pessoa que faz 
a VIsita em casa... para a pessoa doENte... acho MUlto importante... eu... eu introduzi na cidade de São Paulo esse proGRAma... quando eu vi funcionar em outros paísES... a pessoa doente... às vezes mora sozinha... tem um visitador que ajuda diariamente...

L1: pergunta aGOra... da senhora MARta SupliCY ao senhor Gilberto Kassab...

L2: todo mundo sabe que o TRÂNsito dessa cidade é um dos piores problemas... um problema que chegou no piOR nível na sua gestão... aTUal... é poluiçÃO... é::... sofrimento de TOdas as classes sociais no trânsito... eu na prefeitura... eu fiz... eh... DEZ corredores de ônibus... né?... e ajudou muito a fluidez do trânsito... você promeTEU fazer CINco corredores... e não fez neNHUM... eu fiz CEM quilômetros de corredores... e você não fez nenhum... ao mesmo tempo você também promeTEU investir trinta e dois quilômetros do Fura Fila para chegar até a Cidade TiraDENTES... fez oito quilômetros e era dinheiro do governo fedeRAL... então a minha pergunta é... COmo é que você explica que em QUAtro anos você não fez neNHUM corredor?...

L3: a resposta é muito simples... candidata Marta... eu não quero ser um prefeito conhecido por colocar PLAca em obra... eu quero fazer o que tem que ser feito... e as obras de infra-estrutura... são de longo prazo... por isso que pela primeira vez um prefeito coloca recursos no metrô... serão UM Bllhão de reais... e o dinheiro já está em caixa... aliás... como você vive dizendo... é que precisamos encontrar 0 projeto certo e o governador José Serra... com sua exCElente equipe... já está definindo os projetos... e em relação aos corredores... corredor... para ser corredor MESmo... para diminuir o tempo de viAgem das pessoas... precisa ser um corredor que tem área de ultrapassagem no ponto de parada... precisa ser corredor que não tem cruzaMENto... para que a pessoa se sinta incentiVAda a deixar o carro em casa... e com isso... melhorar o trânsito... e é isso que nós estamos fazendo... os nossos dois corredores... está aqui o nosso competente secretário Alexandre Morais... tem essas características... o corredor CELso Garcia... que sai do centro de São Paulo e se dirige até o Itaim PaULISta... passando pela Penha... pela Celso Garcia... por São MiGUEL... e ficará pronto... está em fase de licitação... ficará ponto no:: final de dois mil e nove... e o corredor Expresso Tiradentes... saindo também do centro de São Paulo... passando por Sacomã:.... Vila Prudente... chegando até... são mateus... chegando até a cidade tiradentes... trinta e dois quilômetros... é evidente... GRANdes obras... eu não vou colocar NEssa gestão meu nome na placa... mas o importante é que está sendo feito o que precisa ser feito... infelizmente... os prefeitos que me antecederam... não se preocuparam em investimentos de longo prazo... e estamos fazendo ISSO e vamos deixar São Paulo pela primeira vez com investimentos no meTRÔ no RodoANEL... e também em corredores de ônibus... estamos fazendo a lição de casa... porque... não é com falsas promessas que nós vamos resolver o trânsito... eu não quero que daqui há vin/... daqui há vinte anos as pessoas LEMbrem do Kassab... - poxa... se o Kassab tivesse investido no metrô... como elas se lembram de prefeitos de vinte... trinta anos atrás que não investiram no metrô... no RodoANEL... em corredores... como devem ser feitos MESmo...

L2: você está lá... Kassab... há QUAtro anos... né?... dois anos e quatro meses... só você na sua gestão... bom... está lá há quatro anos e não fez nenhum quilômetro de corredor... e propôs... e falou que ia fazer... prometeu fazer cinco quilômetros de corredor... o MAximo que você fez para o trânsito até agora... foi falar que vai dar um bilhão para o meTRÔ... do qual só deu duzentos e setenta e cinco milhões... então... eu que peguei a cidade com DEZ bilhões a menos... eu fiz cem quilômetros de corredor... e... e corredores que ajudaram MUlto... e você fica 
dizendo que o corredor não ajuda... não foi... não valeu e tal... bom... os corredores... eh:.... quando não tem o/... a maioria tem ultrapassagem... você vê o Teotônio VilEla... o do IbirapuERA... o da Nove de julho... todos esses tem ultrapassagem... da Rebouças não tem ultrapassagem... por que?... porque para ter ultrapassagem teria que desapropriar... CAsas de uma região muito Rlca... e o meTRô... iria estar logo ali... não está lá... logo ali... mas foi feito com essa intenção... foi planeJAdo com essa intenção... o governo do estado não entreGOU... o metrô... por isso que não foi feito... agora você não entregou NENHUM quilômetro da...

L1:

[

L2:

tempo...

da promessa...

L1: $\quad$ sua tréplica...

L3: olha eu... até abro mão do direito de resposta... pra... não complicar os nossos... juristas... mas eu quero dizer que eu fiz corredores sim... entregamos esse primeiro trecho do Expresso Tiradentes... entregamos parte do corredor da Vereador José Diniz... e VAmos entregar... na próxima gestão... a conclusão do expresso Tiradentes e do Celso Garcia... esTAmos... investindo no metrô... está aqui o secretário do estado... o secretário PorTELA... que... sabe do que eu estou falando... e... vamos investir já em... já investimos no proJEto da Freguesia do Ó... no projeto e na execução das obras do corredor... do metrô de Santo Amaro... e até o final do ano... completar um bilhão de reais... portanto... eu queria dizer a candidata... que eu estou MUlto tranquilo... quanto aos nossos investimentos no transporte público... e INfelizmente... nós temos que efetivamente investir no transporte público e falar a verdade para as pessoas... nós não vamos resolver as coisas de uma hora para a outra... mas que está melhorando... tá melhorando...

L1: aGOra é o candidato KAssab... é que PERgunta para a candidata Marta Suplicy...

L3: ao longo desse debate... eu tive oportunidade de falar de uma série de realizações... de uma maneira mais organizada... eu queria lembrar aqui... as Amas... que tiveram avaliação do Instituto lbope... de parte dos usuários... que deram nota acima de nove... os DOis novos hospitais... o programa Mãe PaulisTAna... o Aprendendo com SaÚde... o ReMÉdio em casa... o fim das salas de LAta... das escolas de LAta... eh:.... eu queria dizer... e questionar aqui a exprefeita... em relação à:.... a seus investimentos e a maneira como ela deixou a cidade de São Paulo... eu:.... nós encontramos também a cidade numa situação muito difícil... eu diria que a cidade quebrada... está aqui os jornais da época... lembrando a fila de credores... e ela... preferiu investir em túneis... o malOR investimento de sua gestão foram dois túneis na região dos Jardins... o maior investimento meu... foi saÚde e educaÇÃo para os MAis desfavorecidos... eu queria que ela expliCAsse eXAtamente essa questão dos números da dívida que ela deixou... porque a fila...

L1:

[

L3: tempo...

de credores existia...

L1:

tempo... 
investimos...

L3: $\quad$ e a dívida também...

L2:

[

assim como eu investi no túnel que pre... que ajudou muitas pessoas que vem da zona SUL... e que muitos até usuários de CArros passaram a andar no ÔNIbus... e que agora os corredores estão mal porque você não fiscaLIZA... eu também investi em asfalto... eu investi em inúmeras obras... deixei VÁrias obras programadas... fora a Radial Leste que eu FIZ... A Jacupêssego... a Ponte Estaiada que eu deixei já com as... os pilares prontos... então muita obra foi feita... incluSIve os dois hospitais que você FAla... esses dois hospitais a população sabe quem fez... veja a minha votação em Cidade Tiradentes... que foi sessenta e dois por cento... e a sua que não chegou a quinze... ou... na M'Boi Mirim... o pessoal sabe quem fez o hospiTAL... a minha votação foi de sessenta e quatro... sessenta e três por cento... e a sua também não chegou a quinze... então a população... não adianta você falar que foi você quem FEZ... a população sabe quem suou a caMlsa para fazer isso... entende?... e o Remédio em CAsa... que você fala e tal... olha... o Remédio em Casa é desse tamainho... para o número de pessoas que recebem o remédio em casa... então agora... com MAis dinheiro na prefeiTUra... né?... que eu não deixei quebrada... essa fila de credores que você FALA... vocês instiGAram... eu lembro novembro e dezembro... tendo perdido a eleiÇÃO... e vou aproveitar para dizer que isso me magoou muito... falavam que não ia paGAR... que ia deixar quebrada... instiGAram a população... a passar... os que tavam/... tinham o que receber da prefeiTUra... a paSSAR veXAme lá no sol... na chuva... sendo que chegou em janeiro... vocês já tinham UM BIlhão e cem mil nos cofres da prefeiTUra... e no final do ano dois bilhões e meio... então... me desminta isso... me desminta... é verdade ou não é?... então... o que tinha para ser pago tinha o dinheiro ali para pagar... e vocês não tiveram a compeTÊncia de usar esse dinheiro... isso que me deixa aflita... quando eu vejo... faltando TUdo na cidade... vocês com dinheiro no mercado financeiro... durante TOda a gestão... e isso realmente deixa alguém... que se... que CUIda das pessoas... que fica agoniAda com as pessoas... indignada...

L3: como a própria candidata disse aqui... a população sabe quem fez... e a população sabe... eu tenho visitado esses bairros... quem fez os hospiTAis... quem fez as cento e quinze Amas... quem acabou com a taxa de lixo... com a taxa de iluminação pública... se tem algo que... a ex-prefeita fez... foi criar taxas... criar impostos... foi... efetivamente... fazer Túneis... plantar coqueiros... mas a nossa administração... ela privilegiou sim os mais humildes... ela investiu MUlto... por exemplo... na área de urbanização de favelas... temos ações ao longo de um... ao longo desse governo... em noVENta e nove favelas... beneficiando mais de treZENtas mil pessoas... TEmos ações efeTIvas na melhoria da qualidade de VIda das pessoas... seja no combate à poluição visual... seja no combate à poluição do ar... seja na melhoria do ensino público... E... as pesquisas do lbope realizadas recentemente... indicam a satisfação dos usuários com os novos serviços... portanto... eu posso aqui RAtificar o meu entendimento... a ex- 
prefeita... realmente... poderia ter investido melhor os seus recursos... e deixou a situação MUlto difícil financeiramente na prefeitura...

L2: reafirmo que não deixei... MAS... não vou voltar a repetir o que eu acabei de falar... mas eu vou falar uma coisa para esclarecer de uma vez por todas... a/... ao Kassab... para ele não ficar repetindo isso... como temos mais dois debates... e a você eleitor... as TAxas foram feitas numa situação de peNúria na cidade... né?... e na qual ele era parTícipe do Pitta... MAS eu-NÃO-fa-rei-ma-is-ta-xa-nes-as-ciDA-de... a gente aprende com a vida... NÉ?... e eu não vou fazer mais taxas... não tem necessiDAde... a cidade hoje está MUlto mais rica... GRAças a política econômica do PREsidente Lula... e não tem necessiDAde... mas eu quero dizer que voCÊS... você Kassab... prometeu que em dois mil e CINco ia extinguir a taxa... não extinguiu... extinguiu no ano seguinte... e agora... eu soube... que... mais de setecentas mil pessoas receberam... em casa... cobrança da taxa que você disse que ia extinguir... em dois mil e cinco... eu quero deixar aqui um compromisso... eu vou aNIStiAR essas pessoas... que em dois mil e cinco não é mais... ((aplausos))... taxa...

L1: a próxima pergunta cabe à::... candidata Marta Suplicy...

L2: na sua propaganda... Kassab... você começou a dizer que tinha feito vinte e cinco Ceus... aí foi um veXAme porque foi evidente que não tinha feito... aí diz que IA entregar... até o final da gestão... os vinte e cinco Ceus... eu fui visitar agora o Ceu de Vila Formosa... né?... porque você agora entregou só catorze... eu fui ver aquele... como é que estava... não tem Ceu... ali eu vi um terreno e a população de Vila Formosa indigNAda... porque não tem Ceu nenhum... e consta como vai ser entregue até o final do ano... não tem como ser entregue... é o terreno com uma terraplanagem... não tem... não tem ali como fazer... a pergunta é de novo em quem acreditar... porque UM é o Kassab preFElto... REal... que fez catorze Ceus... o outro é o da propaGANDA... que diz que vai entregar vinte e cinco Ceus... em quem que a população deve acrediTAR?... Kassab...

L3: bom... que queria que o:.... nosso telespectador... observasse bem... que ela acabou de dizer... que esTEve visitando o terreno... com certeza é... o mais atrasado da prefeitura... ela não ia aqui lembrar do que está mais adianTADO... e esse terreno... ela lembrou... que tem obras de terraplaNAGEM... então aqui vai responder o prefeito e o engenheiro... eu posso afirmar... e não é dezembro... é fevereiro... Marta... e até fevereiro... pelo menos as aulas... já vão estar/... sendo começadas lá nesse Ceu... porQUE... e você... aí eu tenho uma divergência com você... eu inaugurei há três meses atrás um Ceu... e as instalações não estavam todas prontas... e você veio... "que absurdo... o Ceu começar a funcionar sem o auditório..." olha... eu prefiro muito mais as crianças começar as aulas no Ceu sem o auditório... sem piscina... mas FOra de uma escola de LAta... do que elas ficarem alguns meses a mais ficar esperando ficar o Ceu e continuar numa sala de lata... (numa escola de lata)... É uma divergência que eu tenho com você... e fique tranquila... o engenheiro que está me assistindo sabe que... obra de terraplanagem... é a MAIS LENta... é a mais difícil... porque quando começa a construir... a crescer o prédio... em dois meses faz... portanto... eu agradeço você ter dar o seu... depoimento... o seu testemunho... porque isso mostra que estamos no caminho certo... e iREmos sim concluir sim os vinte e cinco Ceus porque o que está MAIS atrasado é esse... com as obras de terraplanagem... que o difícil mesmo foram as desapropriações... porque era tudo terreno complicado que a exprefeita deixou... mas resolvemos tudo... todos estão em obras... e esse também... e eu convido todos vocês... você também candidata Marta... a estar comigo... se 
Deus quiser... se o eleitor confiar na nossa proposta... como prefeito inaugurando isso em fevereiro... esse Ceu...

L2: olha... eu posso não ser engenheira... mas a... o mínimo eu entendo tendo sido prefeita... é impossível... porque... precisa pelo menos começar a fundação... tem uma... é uma movimentação de terra gente... como é que uma movimentação de terra... novembro dezembro janeiro e fevereiro... em quatro meses tem uma criança numa sala de aula?... nem fazendo milagre... então... eu também não sei se esse é o pior... porque eu não fui... não escolhi esse... porque era o pior... eu fui nuns que me disseram que não estavam prontos... eu não sei como estão os outros... Kassab... mas se a argumentação for igual a que você está me dando... Olha... não é... não dá para acreditar... agora... o mais importante... eu acho... que é para você que está em casa precisa saber... é que ele não acredita no Ceu... ele demorou dois anos para começar o Ceu... e tinha dinheiro SIM... a prefeitura de São Paulo têm dinheiro da educação... trinta e um por cento do orçamento... que é gigantesco agora... podia ter feito... mas não acredita... E sempre chamou de escolão... o Psdb e o Dem votaram sempre contra... diziam que era coisa de rico... que não tinha o que fazer... aí as comunidades se organizaram e exigiram que... constrangidos... estão tentando fazer...

L3: a minha administração... telespectador... ela teve a coRREção... com voCÊ... população paulistana... de dar sequencia a bons projetos que foram implantados na cidade de São Paulo... o Ceu é um bom projeto... eu apenas comecei pelas escolas de lata... pelas salas de lata... Aperfeiçoei... os meus projetos são melhores Ceus... foram corrigidos os projetos... e SÃO mais baratos... o bilhete único foi um bom projeto... eu aperfeiçoei... esTENdi para o metrô... aliás foi o exgovernador... o nosso querido ex-governador... o ex-prefeito... o querido governador José Serra... estendi ao metrô... aos trens... é evidente que... agora pudemos aumentar para três horas... implantamos o Amigão... portanto... eu não era contra os Ceus... eu era contra dar prioridade aos Ceus.... minha prioridade era acabar com as salas de lata... com as escolas de lata... tanto é... que o Ceu nosso que está em obras mais atraSAdas é esse que a ex-prefeita acabou de lembrar... e que vai ficar pronto até fevereiro...

L1: agora... candidato Gilberto Kassab... o senhor tem DOis minutos para as suas considerações fiNAis...

L3: eu queria... cumprimentar a candidata pela sua participação nesse debate... cumprimentar o nosso mediador... o Boris... à Rede Bandeirantes... pela promoção que faz desse importante deBAte... a voCÊ... telespectador... e dizer que... ao longo desse segundo turno... nada mas/... nada vai me afasTAR... do debate das iDElas e das propostas... todos sabem... e todos conhecem a exceLENte equipe que tenho... todos sabem que já faz:: dois anos e quase seis meses... que SOu o prefeito da cidade de São Paulo... uma prefeitura que deu sequência à gestão do então prefeito José Serra... que tem o comproMlsso de melhorar a qualidade de vida das pessoas... que administrou os recursos públicos com MUlta serieDADE... com muita responsabilidade... com muita austeridade... e que apresenta resultados extraordiNÁrios... na cidade de São Paulo... em TOdos os campos... e que tem a humilDAde... de dar seQUÊNcia a bons projetos... que de... nossos antecessores... que tem também a COragem... de enfrentar a MÁfias na cidade de São Paulo... dos POStos de gasolina... dos MAus empresários que agiam criminosamente com a poluição visual... que... enfim... soube fazer e soube implantar... a ORdem na cidade de São Paulo... SOUbe trazer receitas para a cidade de São Paulo... soube fazer imporTANtes parceRlas com o governo do Estado... com o governo fedeRAL... a ex-prefeita vive aqui citando o presidente 
Lula... mas o presidente Lula... ele investiu DEZ vezes MAis na minha gesTÃo do que na gestão da ex-prefeita... por que?... porque nós temos projetos para a cidade... ela não tinha projetos... e na medida em que nós temos proJEtos... viERAM os recursos do governo federal e do governo do Estado... ela Clta aqui o governo do EsTAdo mas ela não soube apresentar proJEtos para o exgovernador Geraldo Alckmin... que chegou a inclusive deixar CEM milhões para a habitação disponível... e não foram utilizados pela gestão da ex-prefeita... portanto a todos vocês que nos assistiram... MUlto obrigado... e que a gente tenha a oportunidade de contiNUar debaTENdo os problemas da cidade de São Paulo... ao longo dessa campanha... muito obrigado mesmo... ((aplausos))...

L1: considerações finais... aGOra... da candiDAta Marta Suplicy...

L2: eu quero agradecer à Band por esse deBAte... ao candidato adverSÁrio... também ao BOris... e a voCÊ... principalmente... que está em CAsa e assistiu esse debate até agora... quero agradecer também os VOtos... quero pedir a confirmação desses Votos... no dia vinte e seis... e ao mesmo tempo pedir a você... que não votou em MIM... que reconsidere... e que pense... e que PEse as propostas... a credibilidade de CAda candidatura... e o que pode ser feito para você de bom... eu aprendi basTANte... né?... como prefeita... agora também aprendi agora... na maturidade... mais experiMENTAda... eu acho que a gente pode fazer muito MAis... e muito meLHOR... e eu tenho propostas... eu tenho propostas para arruMAR esse TRÂNsito... para aumentar o transporte na ciDAde... para fazer os corredores que ele não fez nem um quilômetro... a não ser oito do fura-FILA... mas não fez... não cumpriu a promessa... dos CINco quilômetros de correDOR... nós vamos fazer... agora a cidade tem dinheiro... VAmos por o dinheiro no meTRÔ... leVAR esse dinheiro do metrô para a periferia... para que chegue em Vila Nova Cachoerinha... na LApa... no Jardim Ângela... M'boi MiRIM... SapoPEMba... para a Vila MaRIA... porque a gente vai por $0 . .$. o recurso e vai sentar para conversar sobre esse recurso... né?... e também na saúde... porque hoje você tem três portas de atendimento... né?... você tem... as Amas... as Ubss e o programa de Saúde da FaMília... e aliás... o programa de Saúde da Família... eu deixei oitocentas equipes... e o opositor... duZENtas... né?... e agora... isso tudo... está sem comunicaÇÃO... porque não houve a informatização... a pessoa entra... por essa porta de entrada... NÃO consi/... quando ela consegue a consulta... ela não consegue depois a consulta de especialiDADE... eu sei fazer as prioriDAdes... e trabalhei com MUlto POUco dinheiro NEssa ciDAde... e o meu parceiro... o Lula... agora está com dinheiro... tanto é que mandou para você... ele é um presidente republicano... mas como ele diz... "com você Marta... é OUtra coisa... nós somos time..." ((aplausos e vaias))...

L1: e termina aqui o primeiro encontro desse segundo turno... entre os candidatos à prefeitura de São Paulo... eu gostaria de agradecer... às presenças dos candidatos Gilberto Kassab e Marta Suplicy... e a BAnd escreve assim... MAis um capítulo de sua LONga história na realização de debates políticos... e logo após o terceiro tempo... o Canal Livre especial vai discutir a campanha eleitoral e avaliar os deBAtes de hoje... em SÃO Paulo Belo Horizonte e Rio de Janeiro... eleiçÕES dois mil e oito... debate... você na Band... boa noite... ((aplausos))

((vinheta de encerramento do debate))

L6: fim do debate... vamos conversar com os candidatos à prefeitura... candidato Kassab... qual é a avaliação que o senhor faz do debate?...

L3: uma avaliação muito positiva... o debate do segundo turno nos dá essa oportunidade... porque o debate do segundo turno... faz com que a gente POssa... pelo tempo existente... aproFUNdar as discuSSÕES... fazer com que o eleitor... 
e telespectador... enTENda CAda tema apresenTADO... compreenda as nossas realizações... e compreenda as nossas propostas... conheceram divergências... em relação ao que pensa a candidata Marta... ela... tem alguns aspectos... de seu programa de governo que divergem do nosso... principalmente investimentos na saúde... nós vamos continuar investindo mais do que a lei prevê na saúde... vamos continuar investindo no ensino público... na melhoria da qualidade do ensino público... investindo nos professores... nos servidores...

L6: agora... candidato... o senhor espera que o TOM do... da campanha... seja o tom desse debate?...

L3: olha... eu espero que... prevaleça... ao longo da campanha... o debate de propostas... É ESSA e expectativa do paulistano e é essa a minha expectativa... eu vou continuar tendo esse comportamento porque é mais compatível com essas expectativas...

L6: obrigado... vamos conversar agora com a repórter PaTRÍcia Zorzan que está com a candidata Marta Suplicy...

L7: isso mesmo... Sérgio... nós vamos conversar agora com a candidata do Pt Marta Suplicy... candidata... como é que a senhora avaliou a participação da senhora?... a senhora subiu bastante o TOM nesse debate... esse vai ser o ritmo daqui para a frente?...

L2: não... eu acho que eu subi o tom... se subi... num momento em que foi mais acirrado... o que num debate é permitido... né?... eu acho que se você está dando entrevista na rua não... mas num debate... a outra pessoa está ALI... um responde... o outro fala... aí eu acho que é permitido... nós DOis... eu acho que subimos o tom em diferentes momentos... e eu acho que foi muito... muito proveiTOso... porque nós marCAmos os campos das diferenças... né?... eu acho que nenhum dos dois conseguiu aproFUNdar tanto as propostas... mas os CAMpos estão demarCAdos... os campos estão demarCAdos... o Gilberto Kassab é do PfL... não adiante se travestir de PsdB... ele TEM uma trajeTÓria CLAra na sua vida... e nós já tivemos NEssa cidade... um preFElto que ganhou com propaganda engaNOsa... se chamava PItta esse prefeito... ganhou com propaganda engaNOsa... e um... um chefe... que naquele momento era muito podeROso... e o que aconteceu com a cidade?... a propaganda enganosa se transformou na realidade que nós vivemos com o Pltta... isso eu acho que as pessoas não sabiam... eu acho que muito hoje souberam...

L7: ok... muito obrigada... nós voltamos com o repórter Sérgio Gabriel...

L6: nós vamos conversar agora com o jornalista Boris Casoy... que foi o mediador do debate... que está comentando aqui como é que foi o debate hoje... não é... Boris?...

L1: eu estava dizendo aqui na Band News... QUE:.... o debate hoje foi diFícil para mim... que o debate é engessado... e tem pouca intervenção de improviso... mas dessa vez eu fui obrigado... e... teve uma... uma sen-sa-ÇÃo muito forte... de tenSÃO... quer dizer... AQUI... tinha eletricidade... tinha CINco mil voltz circuLANdo... viu?... que a tensão era muito FORte a tensão entre os asseSSOres... as coisas que eu ouvi... da... da plaTEla... né?... você não pode reagir a TUdo... os peDIdos de resposta e tudo isso... foi um debate tenso... ah... em neNHUma das veZES... em que eu devia dizer... "passa para o senhor..." "passa para a senhora.." eu O fiz... eles foram autoMAtiCAMENte respondendo e DEU uma dinâmica melhor ao debate... FOI sem querer... foi normal... agora... 0 debate foi MUlto tenso... ah.:... ah... as... as... a apaRÊNcia de calma que eles deMONStravam... perante as câmeras... que eles NÃO revelavam nos intervalos... tá certo?... ah... o... foi um debate... e olha... foi DUro de fazer... eu confesso que eu tenho uma GRANde experiência em debate... mas esse debate que eu... eu 
tive reCElo... eu tive receio... ah:.... em determinado momento... que as coisas pudessem degringolar aqui... me assusTOU... aí você se sente... piloTANdo um negócio giGANTESco... e pressio... esse novo formato... de ter a plateia atrás... eu me senti pressionado pela frente e por trás... em determinados momentos... não é que eu fiquei com medo... mas é uma... uma sensação nova... você ter uma caNHÃO por trás... se tiver pela frente... pelo menos você consegue se desviar... eu ouvi coisas... insinuações até graves... de pessoas que estavam nas minhas costas e eu não podia revidar... eu preferi ignorar... tá certo?... e não reagir... fingir que não ouvia e tal...

L6: obrigado Boris... vamos conversar agora com a repórter Patrícia Zorzan...

L7: Sérgio... e nós conversamos agora com o Fernando Mitre... diretor de jornalismo da Tv Bandeirantes... Mitre... um debate muito disputado... os candidatos com um tom bastante agressivo... e manifestações até da plateia...

L8: eh... o debate foi BOM e bonito... não é?... quem queria confronto... teve TOdo o confronto possível... foram DUas horas e tanto... de corpo a corpo entre os candidatos... a expectativa era essa... ela se re/... ela se realizou até um pouco aCIma do que se esperava... acho que HOUve um debate de conteúdo... houve um debate de estilos... houve um debate de humores... foi um debate completo... e estava muito bonito... televisivamente... estava muito bonito... então... eu acho que aGOra o telespectador... coMEça a ter condições REAis de... de FAto... manTER ou mu... manter sua decisão... ou mudar a sua decisão... ou ter a decisão que não tem... de maneira consciente...

L6: ok... muito obrigado... eleições dois mil e oito... debate... você decide na Band...

((vinheta de encerramento do debate)) 


\author{
ANEXO 3 \\ Programa exibido no dia 19 de outubro de 2008, com duração de cento e nove \\ minutos e quarenta e nove segundos. \\ L1: Celso Freitas. \\ L2: Glberto Kassab. \\ L3: Marta Suplicy. \\ L4: Adriana Araújo. \\ L5: Cristina Lemos.
}

\title{
((Música de abertura))
}

L1: boa noite... o eleitor da cidade de São Paulo acompanha ao VIvo... a partir de agora... pela REde Record... com cobertura da Record News... o debate deciSIvo entre os candidatos escolhidos para disputar o segundo turno da eleição... o debate pode ser acompanhado pelo site da Record... no endereço www.rederecord.com.br... estão aqui... para discutir iDEias e planos de governo... o candidato Gilberto Kassab... do Dem... representante da coligação São Paulo no Rumo Certo... boa noite candidato... Gilberto Kassab...

L2: boa noite...

L1: o senhor tem UM miNUto para se apresentar...

L2: queria agradecer a Rede Record pela oportunidade... cumprimentar o senhor e a senhora... a você aí em casa... que participam desse debate... e dizer... da minha satisfação de estar disputando essas eleições... quero contiNUAR prefeito de São Paulo... para continuar as nossas ações que estão melhorando a qualidade de vida do paulistano... São Paulo é uma cidade com iMENsos desafios... mas que ao longo de nossa administração... fomos propondo soluções... e elas foram demonstrando... para os paulistanos... que elas foram adequadas... quero durante a campanha... e aqui nesse deBATE... manter um elevado nível de camPANHA... para continuar falando das Amas... dos novos hospiTAis... do Programa Cidade limpa... para falar da qualidade do ensino público... que TEM melhorado... precisa melhorar mais ainda... enfim... eu quero efetivamente dar A voCÊ... a oportunidade de mais uma vez discutir conosco... as soluções PAra a cidade de São Paulo...

L1: obrigado candidato... a candidata do Pt... representando a coligação Uma NOva Atitude Para São Paulo... Marta Suplicy... também terá UM miNUto para se apresentar... boa noite candidata...

L2: boa noite Celso... boa noite candidato Kassab... quero também dar boa noite também a plateia que está aqui nos assistindo... a jornaLIStas... e a você que está em casa... eu quero conversar com você... eleitor e eleitora... que está nos assistindo... nós começamos agora... com esse debate... é a ÚLtima semana... da campanha... e você vai poder FOcar... e você vai poder escutar as proPOSTAS... vai poder comparar as diferenças dos candiDATOS... o que querem fazer para a cidade... e olha... eu vou dizer para você... eu me considero hoje uma pessoa MUlto experiente... para governar São Paulo... MUlto mais maDUra... aprendi muito... com os aCERtos que fiz nessa cidade... administrando com tão pouco... mas ao mesmo tempo... aprendi MUlto... dos erros que cometi... quero administrar São Paulo para TOdos... e quero também dizer que vou trabalhar MUlto... para combater a desigualdade social... na nossa cidade... e desnoreRAR... de tributos... o cidadão paulistano...

L1: participam... desse debate... nesse bloco e também no terceiro... jornalistas da Rede Record e da Record News... Adriana Araújo... boa noite Adriana...

L4: boa noite Celso... boa noite candidatos... e boa noite à todos em casa...

L1: participa também CRIStina Lemos... boa noite Cristina... 
L5: boa noite a todos...

L1: antes de dar início ao debate... eu quero lembrar que o candidato que se sentir vítima de caLÚnia... injúria ou difamação... poderá pedir direito de resposta... advogados da Rede Record... vão analisar se HÁ fundamento no pedido... em caso positivo... o candidato ofendido terá TRINta segundos... para se defender... a resposta será dada ATÉ o final do bloco... no qual foi feito o pedido de defesa... vamos agora às regras deste primeiro bloco... cada uma das jornalistas alternadamente escolherá um candidato... a quem fará a sua pergunta e pedirá que seu concorrente comente a resposta... o candidato que responder terá direito à réplica... os tempos são os seguintes... pergunta da jornalista... trinta segundos... resposta... dois minutos... comentário... um minuto e quinze segundos... réplica... um minuto... as jornalistas farão duas perguntas cada uma... e a primeira jornalista a participar é... Adriana Araújo... Adriana... quem você faz a sua pergunta?...

L4: Celso... a primeira pergunta vai para o candidato Gilberto Kassab... candidato... o governador José Serra... o seu MAior aliado... disse que a GUErra entre as Polícias Civil e Militar... em FRENte ao Palácio dos Bandeirantes... foi ELEltoREIra... e que o Pt... usou a greve... para tentar enFRAquecer a sua candidatura... já o presidente Lula disse ontem... que o governador José Serra deve desculpas ao Pt por essa declaração... o senhor o que acha?... a greve foi usada para tentar enfraquecer a sua candidatura?... ou concorda com o presidente Lula e acha que José Serra DEve pedir DESculpas ao Pt?...

L2: em primeiro lugar... eu queria aqui registrar... que as reivindicações das policias... têm a sua legitimidade... porém o caminho é o diálogo... polícia... armada... na porta do Palácio dos Bandeirantes... evidente que não é o correto caminho para as reivindicações... o presidente Lula... ontem... fez essa manifestação num ambiente PARtiDÁrio... portanto ele não foi lá como Presidente da República... até porque a lei o impede... então eu entendo a sua manifestação como partiDÁria... evidente... com sua responSAbilidade... ele... vai pensar melhor... ele como Presidente da República... se ele quiser saber pormenores do caso... ele vai ligar para o governador de Sã/... ele vai ligar para o governador de São Paulo... e ANtes de qualquer manifestação como presidente... ele vai pondeRAR... converSAR... e depois se manifesTAR... o governador José Serra tem esPÍrito público... o governador José Serra tem dialoGADO com as poLíCIAS... mas a greve não é o melhor caminho... inclusive... houve SIM... manifestações de parlamentares... o deputado Paulo Pereira da Silva... que está na aliança da minha adversária há uma semana atrás... PUblicamente... já organizava... e fazia manifestações... A favor desse confronto no Palácio dos Bandeirantes... e no dia da manifestação... o deputado Roberto Felício... do Pt... estava ENtre os manifestantes... PUblicamente defendeu a manifestação... e é evidente que... para esses dois parlamentares... faltou espírito público... não HÁ quem na vida pública possa defender... que as poLícias com ARma na mão... vão até o Palácio do... dos Bandeirantes... fazer um enfrentamento... o caminho é o diálogo... o BOM senso de todos... e tenho certeza que... o presidente Lula... não como integrante do Pt... mas como PREsidente da República... porque ele TEM espírito público... ou pelo menos ele precisaria ter... ele vai conSULtar o governador... converSAR e se colocar à disposição para ajudar... com diÁLOGO... para resolver essa questão... um minuto e quinze segundos para a candidata Marta Suplicy comentar...

L3: olha eu fiquei indignada com o que aconteceu... primeiro PASma... não acreditei que ele pudesse estar falando aquilo... asei... achei uma PROvocação... e depois achei que foi uma manifestação eleitoral... porque nós já fomos vítimas no Pt... de várias coisas assim... inclusive na questão do Abílio Diniz quando puseram 
camisetas do Pt... inclu/... agora... eu quero dizer... candidato Kassab... que líderes sindicais... estarem em manifestação... é absolutamente aceitável... depois... essa negociação está desde março... e nos últimos dias no jornal... trinta dias... todo dia... e o presidente falou uma coisa que eu achei muito boa no comício ontem... que ele estava lá como... do Pt... mas também ele é presidente... ele falou... quem não sabe negoCIAR... e não aceita demanda... não pode goverNAR... e essa foi a situação... tavam lá... e esperaram... três horas... não foram recebidos... criou-se uma situação... de CHOque... uma situação hoRROrosa... que vai ter resquício para a Policia Militar e para a Polícia Civil aqui da nossa cidade... por que?... por uma incapacidade de negociar... aliás... isso tem sido relTERAdo... em todas as administrações tucanas... Pfls e Dems... porque não conseguem ter uma MEsa de negociação... onde as coisas possam ser... resolVIdas... civilizadamente... eu fui preFElta dessa cidade QUAtro anos... nunca vivemos isso...

L1: candidato... o senhor tem UM minuto para a réplica...

L2: gostaria que a... ex-prefeita disesse/... dissesse isso... para os professores... para os médicos... para os servidores municipais... que SAbem como foram tratados na sua gestão... sabem como as suas reivindicações eram atendidas... sabem o PAdrão salarial que tinha/... que tinham no início do governo... e que tiveram no final do governo... na administração... aí SErra-Kassab... mostramos o quanto os servidores foram valorizados... e eu não tenho DÚvida nenhuma em afirmar aqui... que o governador José Serra... assim como fizemos na prefeitura... ele no primeiro momento... e eu no segundo momento... VAlorizamos os servidores... ele SAberá valorizar os servidores... e também aqueles da área da segurança... por isso que eu recomendo... diálogo... debate é bom pra Isso... a exprefeita não atendeu NEnhum dos seus servidores... basta comparar... está no Diário Oficial... basta conversar com os servidores... e o governador José Serra... atendeu na prefeitura... e esTÁ atendendo no governo do estado... e com negociação vai saber encontrar o caminho para atender... as forças de segurança...

L1: vamos agora a pergunta da jornalista Cristina Lemos...

L5: a pergunta vai para MARta Suplicy... candidata... a sua campanha começou o horário político do segundo turno... perguntando se o candidato Gilberto Kassab é caSAdo... se tem Fllhos... a propaganda foi considerada precon-CEltuosa... e saiu do ar depois de dois dias de exibição... a senhora se arrepende de ter usado essa propaganda?...

L3: olha... eu fiquei muito espantada com o que aconteceu com essa propaganda... o... a ressonância dessa propaganda... porque... ela foi feita... junta com diversas perguntas... e eram perguntas que foram TEStadas pelo marqueteiro... em GRUpos que se testam para por no ar... e não causaram NAda... ninguém viu aquelas perguntas como malicia... agora... o QUE fizeRAM depois com as perguntas... Aí foi outra coisa... falou-se... criou-se o grande ceLEUma dessa campanha... em relação... àquelas perguntas... as perguntas são perguntas... que dizem respeito... à trajeTÓria DO CANdidato... eu acho que as pessoas tem direito a saber... TOdas aquelas perguntas aLI... e você pode dizer... mas o que é que influencia saber que ele é casado... o que influencia saber se ele era rico... ou ficou rico na política... o que é que influencia saber isso ou saber aquilo... eu acho que são perguntas que de/... que dizem respeito a uma candidatura... então eu acredito... que criou-se TOda essa ceLEUma... não pela perGUNta eXAta... mas porque a perGUNta... e as outras perGUNtas... falavam que a população não conhece Gilberto Kassab... isso que foi... porque... aTÉ enTÃO... ninguém sabia... que ele era... braço direito do PItta... as pessoas não sabiam que ele é do PfL... um partido em extinção no BRAsil... né?... perdeu 
todas as eleições municipais... então era... foi absolutamente imporTANte... para as pessoas conheceREM... quem É o candiDATO... em relação ao RESto... gente... eu digo... eu sou... talvez a pessoa nesse Brasil... que mais defendeu direitos humanos... minorias... e tudo o que estão colocando em cima de mim... olha... principalmente... os grupos gays... homossexuais... todos... eu agradeço 0 apoio... porque sabem que eu NUNca seria parCElra... em alguma coisa que pudesse geRAR... uma confusão e tudo isso... isso aconteCEU... eu rePITO... porque invés de se discutir... poLlítica... e $O$ parTldo DO candidato... ficaram num detalhe... né?... que perverteRAM... para poder discutir OUtra colSA... e não a ficha dele...

L1: comentário do candidato Gilberto Kassab...

L2: quanto ao MAquiavelismo... e as insiNUAções mentiROsas e MALdosas da campanha da minha adversária... a jusTlça se pronunciou... e CONdenou... com MUlto riGOR... a campanha da Marta... ela perdeu mais de quatroCENtos minutos de tempo na televisão... portanto não tenho nada a falar sobre isso... a minha vida... sou solteiro... sou feliz... sou engenheiro... sou economista... e posso dizer à prefeita... e sua campanha... que o cidadão... ele está interessado em discutir o caRÁter das pessoas... ele está interessado em discutir a capacidade administrativa... e o meu governo é MUlto bem avaliado... sessenta e um por cento dos paulistanos entendem que ele é ótimo ou bom... e eu vou continuar me esforçando... para que continue sendo um BOM governo... e em relação ao PItta... eu me afastei dele... agora a ex-prefeita... eu sempre lembro... que ela não se afastou do Delúbio... ela não se afastou do Silvinho... ela não se afastou do José Genoíno... ela não se afastou do José Dirceu... ela NÃO se afastou da turma do MENsalão... ((muitos aplausos))...

L1: a candidata... eu pediria... eu peço encarecidamente à plateia... que evite manifestação durante a... a apresentação dos candidatos... por favor... a candidata tem UM minuto...

L3: eu acho que não se compara uma coisa com a outra... eu pertenço... ((manifestações na plateia)) ... por favor...

L1: por favor... eu volto $a \ldots$ a solicitar novamente à plateia que evite manifestação durante... a apresentação dos candidatos... por favor...

L3: as duas coisas NÃO se comparam... eu perTENço a um parTIdo poLítico... e você pertence a outro... o que está se comparando... é a trajeTÓria de um partido político... e a SUA trajetória nesse partido... e vou aLÉM... a escolha SUa DESte partido... esse é o partido dos coroNÉIS... o partido que levou ao aTRAso... é um partido que não tinha nem LUZ quando o Lula assumiu no norDESte... é o partido que é o retrocesso... e esse parTIdo... é o seu parTIdo... você não saiu DEle... você está lá... faz PARte desse partido... e não adiante dizer que se arrependeu... você saiu depois de dois meses... de dois anos... e o seu partido contiNUou lá... o seu partido foi o partido que derruBOu a cidade... que fez eu pegar essa cidade... completamente arrasada... com a prefeitura faLlda... esse é o partido... e voCÊ... também... liderou todo o reAge Pitta... também não adianta dizer que não sabia... porque foi quem liderou quando queriam fazer um impeachment dele... então é comPLEtamente diferente... eu pertenço a um partido no qual eu tenho muita honra de pertencer... ((aplausos))...

L1: esgotado o tempo... vamos à próxima pergunta... ((aplausos))... eu gostaria de relterar... mais uma vez... à plateia... que NÃO se manifeste durante o debate... por favor... vamos à próxima pergunta de Adriana Araújo...

L4: eu dirijo agora a pergunta ao candidato Gilberto Kassab... candidato... o senhor disse ao LONgo da campanha que o presidente Lula tem sido um ótimo presidente para São Paulo... e o que o seNHOR apóia a MAlor parte dos 
proGRAmas do Governo Federal... já o seu partido... o Dem... faz uma oposição feRREnha ao presidente Lula... afinal... de que lado o senhor está?... do lado do presidente Lula ou do lado do seu partido?...

L2: estou do lado do Brasil... o presidente Lula... quando ele é coRREto com a cidade de São Paulo... e quando ele acertadamente... faz os investimentos que precisariam ser feitos... eu sei reconhecer... e o meu partido... a quem cabe fazer oposição... uma oposição com o espírito público... quando ele criTlca o governo... quando ele apreSENta propostas alternativas... quando por exemplo... ele... com VEEmência... se posiciona CONtra... o auMENTO do número de tributos... coisa que a minha adversária não faz... eu não vi em Brasília... se apresenTANdo em Brasília... pedindo para que o seu partido se posicione CONtra o aumento de tributos... ela aqui em São Paulo diz que não vai aumentar mais taxas... mas... pelo que eu percebo... não será esse comportamento quando ela assumir a prefeitura... porque... por coerência... ela deveria estar em Brasília... peDINdo ao seu partido para votar CONtra os novos tributos... então eu diria que eu sou uma pessoa coerente... e a coerência na vida pública... impõe você sempre falar a verdade... você sempre transmitir ao cidadão... e no meu caso... PRINcipalmente aos paulistanos... quando o presidente aJUda... transmitir que ele está ajudando... mostrar reconhecimento... e eu sempre faço isso publicamente... e o presidente também... em diversas ocasiões... ele registrou a sua satisfação... em ter essa parceria conosco... e volto a dizer... não acredito... que no caso de minha adversária... puder ser eleita... que o presidente Lula vai tratar diferentemente São Paulo... às vezes... ela dá a impressão... que ele vai investir... por exemplo... no metrô... coisa que nunca fez até hoje... apenas se ela ganhar... como o governador José Serra... que tem ajudado muito a cidade de São Paulo... vai continuar ajudando... indePENdente do prefeito... do candidato eleito... porque tem espírito público... portanto eu queria aqui registrar... com muita tranquilidade... que quando for para criticar... criticarei o presidente Lula... e quando for para reconhecer e agradecer... agradecerei...

L3: bom... vamos colocar de novo... com clareza... essa história de taxa... eu fiz um ERRO... e tenho o compromisso aqui com vocês... que não cometerei de novo esse erro... agora vamos falar de impostos... foi o seu governo... junto com o Fhc e o Pfl... quem realmente aumentaram os impostos nesse Brasil... de vinte e seis por cento... do Pib... para TRINta e sete por cento... e foi... o SEu governo... aGOra... aGOra... atual... quem fez o Iss... de dois por cento... para taxista... para florista... para alfaiate... e... se você for ver em... em termos... em salários... valores de hoje... na minha época se pagava cerca de seiscentos e quarenta per capta... por ano de imPOSto... e agora se paga oitocentos e sessenta... então... não tem clareza nenhuma Kassab... vocês gostam de acusar... e eu fico pagando essa coisa... essa questão da taxa equivocada... TOdo debate... agora... assumlr o que vocês fizeram de errado... que o presidente Fernando Henrique fez... e... vocês não reconhecem... inclusive não reconhecem... o presidente LUla... ter feito a desoneração de setenta BIlhões... esse ano... para diferentes setores que estão produzindo... então isso é o nosso presidente... um presidente que traz dinheiro para São Paulo SIM... mas que disse repeTIdas vezes... que se for eu a parceira... o dinheiro verá... virá maior e melhor... porque pensamos os mesmos projetos... ((manifestação na plateia))... L2: lá vem a Marta...

$$
\text { réplica... }
$$


L2:

trazer o Lula para a eleição... aqui... Marta... a gente está querendo avaliar voCÊ como candidata e voCẾ como ex-prefeita... o que é importante o paulistano aqui se recordar... que além das TAxas... que o seu governo implantou... você tentou aprovar VÁrias outras taxas... que graças à Câmara Municipal... não foram aprovadas... são... tem matérias no Estadão lá inclusive... que eu estava relendo hoje... que tinha... se eu não me engano... ONze taxas que você não conseguiu aprovar na câmara municipal... incluSlve você criou uma comissão de advogados notáveis... para estudar a criação de novas taxas... a sua preocupação... a sua obs... obsessão com TAxas... ela era muito grande... tanto é que te incomoda muito... e eu te digo... não é apenas durante os debates... durante essa campanha que você vai ter que se explicar sobre as taxas... vai ser durante todo o resto de sua vida pública... você foi preFElta de São Paulo... e você implantou MUltas taxas... isso incomodou deMAis o paulistano... PE-na-li-zou os paulistanos... e é por isso que nós sempre relembramos... para que o cidadão... o eleitor... pergunte... qual Marta a gente vai acreditar... naquela que fala que não vai criar taxas ou a que criava taxas...

L1: vamos... agora a pergunta da jornalista Cristina Lemos... por favor... Cristina...

L5: pergunta para MARta Suplicy... candidata as pesquisas indicam que a senhora tem uma TAxa de rejeição que chega a TRINta e cinco por cento... o que significa... que a senhora só perde... para o deputado PAUlo Maluf... aqui... aqui em São Paulo... a que a senhora atribui uma taxa de rejeição TÃO alta?...

L3: olha... primeiro eu quero falar... que começou a copiar até no debate... eu só sou uma... Kassab... só sou uma... e transparente... e o que eu falho... o que eu erro... eu assumo... a outra questão... essa história que eu estou trazendo o Lula para o debate... trago com muita honra... agora você tem que VER que 0 debate... o Lula... foi trazido pela pergunta... então você já entortou a coisa... e a questão de taxa... que você disse que viu várias... não sei o que... não sei o que... olha... então diga quais são... porque eu não sei dessa mesa que você falou... não sei desse grupo que você fez... e se foi... eu não sei disso que você está falando... o que eu fiz eu assumo... ao contrário de você... agora... em relação à rejeição que você está coloCANDO... eu... olha... São Paulo é uma cidade... que o Pt realmente tem MUlta dificuldade... eu acredito que nós aqui temos a cidade mais diNÂmica... rica... e de mobilidade social do país... e tem coisas que eu tenho percebido... e tenho percebido agora... também... com a:: questão de tanta gente mais pobre ter entrado na classe MÉdia... classe média ainda sofrida... e que imediatamente diz... eu não quero mais nada com quem é pobre... porque agora eu tenho que defender... e já vou... para o outro lado... que... com quem eu quero me identificar... sabe que isso eu tenho noTAdo... inclusive... as pessoas RApidamente... querem se afastar... eu acredito que nós aqui temos propostas para a cidade inTElra... né?... e eu também acredito que camPAnha... de preconceito que eu já sofri nessa ciDAde... BASta ver a última com essa... com esse comercial que aconteceu... a própria Folha de São Paulo hoje... o ombudsman... fala que o espaço que deram foi um espaço completamente enlouquecido pela questão que a maioria das pessoas nem TInha achado nada... então a camPAnha que fazem também contra mim é... é uma campanha... olha... não sei também se é pelas coisas que eu deFENdo... pelas mulheres... pelos negros... pelas minorias... pelos homosseXUAis... também isso pode ter alguma coisa a ver... mas eu vou continuar a defender... as pessoas que acredito... as coisas que eu acredito... as causas que eu acredito e os pobres dessa cidade... 
L1: candidato... tem um minuto e quinze para comentário...

L2: quanto as taxas Marta... aguardem depois do intervalo... que eu vou pegar com a minha assessoria... que é uma lista TÃo grande... mas eu lembro que tinha até TAxa de coxinha... ((risos))... eram muitas taxas mas... aguardem... em relação as pessoas que se manifestaram... pode interferência?...

L1: eu gostaria de pedir encarecidamente à plaTEIA... que foi convidada para assistir... NÃO perturbar o nosso debate... por favor...

L2: a gente agradece...

L1: tá?... o cronômetro foi parado e volta ao início... dando uma chance ao candidato responder...

L2: então... vamos voltar... em relação às taxas... aguardem o intervalo... logo após o intervalo... é uma relação MUlto grande de taxas... que a ex-prefeita propôs... encaminhou... e não foram aprovadas... e se não encaminhou... quis encaminhar... inclusive matérias do jornal $O$ Estado de São Paulo... na época registraram... em relação à manifestações de formadores de opinião... que criticaram a campanha SÓRdida do Pt... que foi veiculada e condeNAda pela justiça... eu queria dizer para a candidata... que companheiros seus de partido... criticaram publicamente a campanha... Ricardo Berzoini... presidente naClonal do PT... Aloĺsio MERcadante... seu EX-marido Suplicy... Ideli SalvaTI... LuÍsa ErunDIna... ZÉ Dirceu... miNIstro MARco Aurélio Garcia... miNIstro Miguel Jorge... em determinado momento... até o presidente Lula... portanto... os SEus colegas de partido já se manifestaram... muito obrigado...

L1: um minuto para a candidata Marta Suplicy...

L3: olha... o que eu quero dizer... é que preconceito é isso mesmo... quando você... põe a cara para bater... e defende uma/... causa como eu defendi a VIda inTEIra... aí você paga por crimes comeTIdos e não cometidos... eu quero dizer... que eu REltero aqui... esse comercial que foi veiculado... eu não havia visto... fez parte da minha campanha... não tenho como dizer que não fez parte da minha campanha... agora... foi retirado do ar... foi retirado do ar co/... por meu pedido... já estava meio programado para ser retirado segundo o meu marqueteiro... mas eu falei... eu não admito isso por causa... olha a repercussão que aconteceu... e eu... sinto que tenha molesTAdo ao candidato... e também a outras pessoas do meu partido... porque a intenção... NÃO foi essa do marqueteiro... e... foi uma situação bastante constrangedora... e que para mim... que fui sempre defensora dos direitos humanos... foi uma situação absolutamente muito doída...

L1: esse debate está sendo transmitido também pela rádio Record... nós encerramos aqui o primeiro bloco desse encontro decisivo... entre os CANdidatos do segundo turno da eleição para a prefeitura de São Paulo... vamos a um RÁpido intervalo ((aplausos)) e voltamos em três minutos com as perguntas de candidato para candidato... ((aplausos))... eleições dois mil e oito... o voto na Record...

((vinheta de intervalo comercial))

L1: a Rede Record... com a cobertura da Record News... transmite o debate decisivo... entre os candidatos ao segundo turno da eleição para a prefeitura de São Paulo... o debate também pode ser acompanhado pelo site da Record... no endereço www.rederecord.com.br... nós estamos iniciando aqui... o segundo bloque/... o segundo bloco que tem a seguinte regra... CAda candidato fará de forma ALterada duas perguntas a seu concorrente começando por Gilberto Kassab... o candidato que perguntar terá direito à RÉplica... o candidato que responder terá direito à TRÉplica... os tempos desse bloco são os seguintes... pergunta... um minuto... resposta... DOis minutos... réplica... um minuto e quinze 
segundos... tréplica... um minuto... Gilberto Kassab faz então a primeira pergunta... o senhor tem um minuto...

L2: Marta... se há um problema GREve no seu governo... era... eram a falta de remédios... tinha unidades... como por exemplo... a Ubs Vila Califórnia... que não tinha uma SIMples vitamina C... uma Dipirona... isso era muito preocupante... isso era MUlto desgastante para a população que... TANto precisa do atendimento público de saúde... e a pergunta que eu quero lhe fazer aqui... é no sentido de você explicar para o nosso telespectador... o eleitor paulistano... por que... você não resolveu o problema de remédio no seu governo... por QUE falTAvam remédios no seu governo?...

L3: olha... Kassab... você deveria saber melhor do que eu... está faltando o tempo... melhor do que eu... você deixou para mim o PAS... eu recebi da gestão/... Pitta... na qual você foi o auxiliar direto... o PAS... que depois de oito anos na cidade de São Paulo... eu NUNca vou esquecer de um almoxarifado que eu entrei com o Eduardo Jorge... e parecia que tinha entrado um bando de gafanhotos... não tinha UM reMÉdio na cidade... UM reMÉdio... os... os hospitais vieram para nós... inteiramente deseQUIPAdos... tendo todos que ser equipados novamente... e nós conseguimos dar saltos giganTESco... nós recebemos a cidade com oitenta e nove Ubss... deixamos com trezentos e oitenta e oito... fizemos o Programa de Saúde da FaMÍlIA... o/... que chegou a ter oitocentas ne/... (Psfs)... você fez só duzentas... metade não tem médico... então nós fizemos um salto gigantesco... com diminuição de mortalidade maTERna... diminuição de mortalidade infanTIL... ao... aumento de exames de PApa NicoLAU... extinguimos praticamente a dengue na cidade... foi um salto MUlto grande... e como... quanto a saLÁrio... que é o que você estava dizendo... que você que é o grande... eh:.... que fez a grande gestão de salário... nós aumentamos em CINquenta e cinco por cento o salário dos médicos na nossa cidade... e foi difícil... porque nós tivemos que contratar QUAtro mil médicos... tivemos que contratar mais de DEZ mil funcionários... para a saÚDE... e na situação calamiTOSA na cidade... na qual nós não tínhamos recurso nenhum... não tínhamos recurso neNHUM... então essa história que você estava falando aí de taxa de coxinha... eu até SEi o que é... sabe o que É?... é quando você fica numa cidade sem NAda... e eu lembro dessa sugestão que foi do Sayad... de taxar isso... taxar aquilo... isso é um debate inTERno que foi parar no... no... no jorNAL... e que eu absolutamente neguei e não deixei fazer... deixei a outra... mas isso foi um erro... que eu peço desculpas à população... mas isso aí que você está falando... são debates inTERnos de dentro de uma prefeitura... e a questão dos reMÉDIOS... você sabe... você diz que dá tanto remédio... eu só ando na rua ouvindo as pessoas que falta remédio... L1: réplica do candidato Gilberto Kassab... em um minuto e quinze segundos...

L2: ((bate três vezes na mesa))... quem depende de remédio tá torcendo para a prefeita não voltar para a prefeitura... a nossa ex-prefeita sabe que... na minha gestão... nós informatizamos a distribuição de remédios na cidade de São Paulo... nos criamos a CENtral de Medicamentos... medidas administrativamente SIMples nos dias de hoje... usando tecnologia... eu faço uma pergunta em relação ao seu governo... e ela responde em relação ao fiNAL do outro governo... ela teve quatro anos para governar... nós também tivemos... e nesses quatro anos... informatiZAMOS a distribuição de remédios... o lbope mostrou... o lbope mostrou... pesquisa feita junto aos usuários... que noVENta por cento deles está saTISfeita com a distribuição dos remédios... pesQUlsa feita pelo Ibope... na PORta das Ubss... na PORta das Amas... porque não faltam mais remédios... os usuários que estão nos assistindo sabem disso... há MAis de três anos que não temos mais problema de falta de remédios na cidade de São Paulo... a nossa 
CENtral de ma/... de Medicamentos... está totalmente informatizado... portanto... eu quero dizer a vocês... que na próxima gestão vamos AMpliAR o atendimento de remédios na prefeitura...

L1: tréplica da candidata em um minuto...

L3: olha... levou quatro anos para recuperar sim o desastre que você deixou... QUAtro anos para recuperar DOze hospiTAIS... quatro anos para poder fazer oitocentas equipes de Saúde da FaMília... QUAtro anos para transformar oitenta Ubss em trezentos e poucas... QUAtro anos para comeÇAR... o projeto de Remédio em casa... que começou na nossa gestão... na LApa... foi o plano piloto que depois você pode aumenTAR... mas não pensem que é um monte de gente que recebe o remédio em casa... porque não É... essa aprovação do lbope eu NUNca ouvi... porque o que eu ouço quando eu saio na rua... é que NÃO tem remédios... FALta reMÉDIO... FALta MÉdico... falta exame MÉdico... é a coisa que eu MAis escuto... por isso que eu vou fazer as poliCLÍnicas... que vão ser exatamente para atender... quem for nas Amas... quem for nas Ubss... quem for na... na... no programa Saúde da Família hoje... e não tiver o médico especiaLISTA... para TER o médico especialista... vão ser VINte e três especialiDAdes... e também a possibilidade de fazer o exame de iMAgem... porque hoje... Kassab... para fazer UM exame de ressonância na cidade... ou mamografia... são seis... oito meses...

L1: candidata... a senhora tem UM minuto agora para a dirigir a sua pergunta ao... a pergunta ao seu... ao candidato Gilberto Kassab...

L3: Kassab... com DEZ bilhões a menos que eu tive para administrar essa cidade... tive que ter uma criatividade para fazer GRANdes obras... eu criei... a:.... operação urbana... pon/... Água Espraiada... e ela era através de vendas de títulos Cepac para o... para o priVAdo... você tinha um dinheiro que não era do orçamento da prefeitura... a idéia era fazer a PONte Estaiada... o prolongamento da Roberto Marinho até chegar na Imigrantes... e ti/... e transformar o Jardim Edith... que é uma FAvela... numa moradia digna... vocês foram CONtra o projeto... depois fizeram a Ponte Estaiada por um custo muito maior... e o Jardim Edith vocês lá... com aquele cheque despejo... e as pessoas se indignaram... e muitos ficaram lá... e estão lá hoje até morando na favela... eu pergunto... por que é que você não CONseguiu acabar o projeto... que é uma operação urbana fanTÁStica... que poderia ter mudado TOda a região... poderia ter FElto em quatro anos... o prolongamento até a Imigrantes... e deixou o projeto só com a ponte?...

L2: em primeiro lugar eu queria dizer... pra:.... Marta... e seu marqueteiro talvez... por não morar em São Paulo... tem esse desconhecimento... que quem criou o che/... o cheque despejo... foi a Marta... através do seu secretário Paulo Teixeira... amanhã está a disposição da imprensa... para que ela possa efetivamente tomar conhecimento... em relação às VERbas do Cepac... aos reCURsos... à receita do Cepac... no meu governo tem pla-ne-já-mento... tem prioridade... e nós demos prio-ridade pra a conclusão... da ponte Otávio Frias... uma ponte que não teve projeto executivo... no nosso governo... portanto... foi agregado o valor do projeto executivo... portanto... está aí a explicação do valor da obra... e nós... demos uma prioridade para o meTRÔ... tanto é... e a todo momento você questiona... eh... mas e o dinheiro do metrô?... essa semana foram CENto e noventa milhões... para o metrô... da região da Água Espraiada... e portanto... depois desse investimento no metrô... agora vem o pro-lon-ga-mento da avenida Roberto Marinho... faremos lá um TÚnel... um túnel ligando diretamente a avenida Roberto Marinho até a rodovia dos Imigrantes... a rodovia AnchiETA... e SOb o túnel... uma avenida... e ao lado da avenida... um PARque... para se integrar com a comunidade... até que esse é o 
nosso compromisso... DElxar com o prolongamento a avenida Roberto Marinho... uma região URbanizada... de acordo com as expectativas da população... e em relação às pessoas que moram no Jardim Edith... o projeto já está aprovado... os entendimentos com as famílias já foram realizado... TOdas elas vão continuar morando... no lugar que moram há mais de vinte anos... construiremos uniDADES habitacioNAIS... em caTORze meses estarão prontas... e o sonho se reali/... irá ser realizado... até parece que em seu governo as favelas não existiam lá e as pessoas deixaram de morar... no nosso governo... a solução já está pronta... os recursos alocados... em caTORze meses... as moradias prontas... com as famílias morando...

L3: provavelmente como... os Ceus que você entrega... porque na verdade... Kassab... você tem QUInhentos milhões da venda do Cepac no banco... e você não utiliZOU... e eu deixei a Ponte Estaiada... já com os pilares... com o projeto todo pronto... você inutilizou... ficaram dois anos contra o projeto... isso já poderia estar TUdo pronto... e cheque para o meTRÔ... você está dando e eu não entendi só porque agora... primeiro porque teve superÁVIT de três bi... no segundo ano quatro bi... tem superávit agora... está no banco... investindo... quatro bilhões e meio no mercado financeiro... podia ter dado esse cheque para o metô... muito antes... mas o mais importante... é falar do Jard/... do Jardim Edith... e dessa favela... o CHEque despejo... na minha gestão... que tratava/ as pessoas muito bem... e não com gás lacrimogênio... nós tínhamos VÁrios tipos de possibilidade para as pessoas... e esse era uma das possibilidades... se a pessoa escolhesse... você... foi obrigado... pelo Ministério Pú-BLI-co... a manter as pessoas lá... porque tentou TIrar as pessoas... tentou tirar as pessoas com uma negociação que atirou gás lacrimogênio... nós não usamos isso... a sua poLítica habitacional... Kassab... é a política do CHEque despejo... a minha... é a política... que usa a urbaNIzação de favelas... que cuida das pessoas... que faz o Bairro Legal... que trabalha... de outra forma com as pessoas...

L1:

um minuto para a tréplica do candidato Gilberto

Kassab...

[

L2:

nós atendemos... DEZ vezes mais... a população carente em termos de moradia... que no governo da Marta Suplicy... eu queria também... dizer... a todos vocês... que:.... efetivamente... o nosso governo... em relação à obras... sabe o que faz... a ex-prefeita... no debate anterior... ela mencionou uma visita que fez ao Ceu VIla Formosa... eu queria convidar a todos... na terça-feira estarei visitando... na terça de manhã... as onze da manhã... o Ceu Vila Formosa... para que vocês entendam o QUANto a ex-prefeita é mal-assessorada com relação à obras... é um Ceu que fiCARÁ ponto até janeiro... é que ela... devia estar acompanhada por profissionais que não conheciam engenharia... e... com os engenheiros dando explicações... mostrando o estágio das obras... vocês vão ver que... FALtou efetivamente BOA assessoria na área de engenharia... no governo... ou pelo menos na campanha... para que ela possa fazer as afirmações que ela tem feito... Volto a dizer... cheque despejo... começou com a Marta...

L1: o candidato Gilberto Kassab faz agora a segunda pergunta para Marta Suplicy...

L2: olha... eu... queria voltar à questão das TAxas... em relação às TAxas que foram criadas pela Marta... eu vou relembrar aqui que foi a taxa do Llxo... a taxa da LUZ... a taxa do asFALTO... a taxa da fiscalização dos estabelecimentos... e 
um aumento de até quinhentos por cento do ISS... além do Iptu progressivo... gostaria de LEMbrar aqui as taxas que... ela discuTIU... tentou criar... e não conseguiu... conforme publicado em jornais... a taxa do elevador... do Iss para anúncios na internet... tá vendo?... vem aí a taxa da internet... do CAminhão... já disse... a taxa da coxinha... taxa do subsolo dos postes... taxa para liberar VEĺculos de rodízio... Marta... como você criou TANtas taxas e mesmo assim... conseguiu quebrar a cidade?...

L3: você imagina... Kassab... o desespero que nós esTÁVAmos... com a situação da cidade... para ter pensado em TANtas alternativas... nós fomos desde a alternativa de criar... o CePAC... que permitiu fazer a Ponte EstaiADA... permitiu fazer os dois TÚneis... o Max Feifer... e o Fernando Vieira de Mello... até... a alternativa de fazer TAxas... agora... eu acho que a ciDAde como eu a enconTREI... você não tem... parece não tem a mais leve idéia do que foi... com o Pas que eu já expliquei o que era... os profesSORES abandonados... criANças fora da esCOLA... um número giGANtesco... e também... pior de tudo... foi o transPORTE... que eu encontrei um CAOS... um caos que as pessoas fiCAVAM aluciNAdas... que não tinham condição de se meXER na cidade... tinham medo daqueles mafiosos... naquelas kombis... e eu arrumei tudo isso... eu arrumei tudo isso... TENdo uma política... di/... direita... criaTIVA asuTERA... pondo dinheiro onde tinha que por... e sem reCURSO fedeRAL... que você está tendo MUlto agora... você fala tanto do dinheiro da saúde que você gasta e tal... TRINta por cento vem do Governo FedeRAL... porque hoje o Governo FedeRAL TEM reCURso... e na minha época não Tlnha... então eu tive que me virar... fiz alguns erros?... FIZ... fiz sim... a taxa da luz é um erro eh... grande... mas você fez um Iss... de dois por cento para taxista... para Músico... para todo mundo... com os cofres da prefeitura abarrotados... me exPLIca... por QU você... que teve já no seGUNdo ano... três BI no mercado financeiro... quatro BI... no ano passado... e tem agora QUAtro bilhões e meio... não desoneROU o povo DEssa cidade... como agora eu estou me compromeTENDO... que a cidade vai ter dinheiro?... eu trabalhei com muita dureza... e fiz o que pude fazer... tive MUltos acertos... e fiz erros também... agora você... que está com TANto recurso... por que não deu dinheiro pro metrô anTES?... por que?... explica... por que que não desonerou mais o transporte?... por que QUE não fez mais creche?... por que que também não construiu esses Ceus lá rapidamente?... se estavam esses Ceus prontinhos para você faZER... por que?... então é essa a pergunta que eu faço... porque eu trabalhei numa circunstância... você trabalha em outra...

L1: acabou sem tempo candidata... um minuto e QUINze segundos para a réplica de Gilberto Kassab...

L2: o que... incomoda a ex-prefeita Marta... é que... nós aumentamos as nossas receitas... e investimos MUlto bem... os recurso provenientes dessas receitas... combatendo FRAUdes... a fraude da catraca... combatendo a soneGAÇÃO... empresas que eu seu governo trabaLHAvam aqui na cidade e... estavam sediAdas em municípios vizinhos... nós obriGAmos elas a vol... a voltarem para o município e voltaram e passaram a contribuir aqui... nós mo-der-ni-zamos a administração municipal... implantamos a NOta-fisCAL eletrônica... que é um eXEMplo para todo o país... referência... e com isso... tivemos a oportunidade de aumenTAR as nossas receitas... e aumentando as nossas receitas... nós fizemos projetos que melhoraram deMAis a qualidade de vida dos paulistanos... a MARta... no último ano de seu governo... ela gastou... ela investiu UM BIlhão e meio de reais na saÚDE... esse é o governo dela... esse é o planejamento dela... eu gastei esse ano... três Bllhões e duzentos milhões de reais... VINte por cento... a lei manda investir quinze... no orÇAmento... que eu encaminhei para a 
Câmara municipal... já consta lá... o ano que vem novamente... VINte por cento do orçamento sendo investido na saúde...

L1: tréplica de um minuto para Marta Suplicy...

L3: olha Kassab... algumas coisas que eu deixei alinhaVAdas... de fiscalização... vocês prosseguiram... mas isso não DAria para a cidade estar com esse orçamento... esse orçamento... beneficiou... esse crescimento do orçamento foi beneficiado pelo governo Lula... TOdas as prefeituras cresceram muito... agora a pergunta que eu FIZ... você não responDEU... qual era a pergunta que eu fiz?... se estava tão bem... estava com tanto dinheiro... por que não de-so-ne-rou o povo paulistano?... EU VOU faZER... estou me comprometendo aqui... não vai ter mais taxas... a prefeitura tem dinheiro... e eu vou desoneRAR o orçam/... vou desoneRAR o cidadão de São Paulo... a primeira coisa que eu vou fazer... vai ser o l-s-s que vai ser exTINto... O Iss para todas as categorias... profissionais liberais... e os dois por cento que você criou para taxista... para músico... para alfaiate... também vou desonerar... e eu vou contiNUar a estuDAR... para ver o que mais eu posso deSONErar... e as pessoas que você cobrou a taxa de luz de Dolis mil e cinco... agora... eu também vou ver um jeito de desonerá-las...

L1: encerrado o seu tempo para a tréplica... candidata... a senhora tem um minuto para a próxima pergunta ao candidato Gilberto Kassab...

L3: candidato Kassab... todo mundo sabe que o trânsito de São Paulo está um horror... um caos... isso tem efeito na... na poluiçÃO... tem efeito nas... nos nervos das pessoas... e eu... quero lembrar... que eu prometi... fiz se... DEZ corredores na cidade de São Paulo... CEM quilÔmetros de corredor... o senhor na sua campanha prometeu CINco corredores... e não fez neNHUM correDOR... também prometeu trinta e dois quilômetros de Fura-Flla... e fez oito quilômetros de Fura-Fila... mas a pergunta que eu quero faZER... é... com TANto dinheiro... com TANto recurso... com TANta capacidade... com tanta coisa... por QUE que não fez o cumprimento da sua promessa?... que eram CINco corredores... que fariam a população de São Paulo... que acorda as CINco da manhã... poder ter mais meia hora de sono... não se importou com essas peSSOas... porque essas pessoas hoje estão pagando um preço MUlto CAro... pela incompeTÊNcia... ou pelo desleixo... não está nem aí... com as pessoas que andam de ônibus e poderiam estar usando o corredor...

L2: TRÂNsito... é uma questão muito séria... aliás... candidatura a prefeito é muito séria também... só para fechar a questão anterior... uma candidata a prefeita... vir a público... e falar que vai extinguir o Iss para todas as categorias... para TOdos os setores... é menosprezar a inteligência do eleitor... nós temos que resPEltar o eleitor... porque sabemos que a cidade precisa de receitas... em relação... ao trânsito... e ao transporte público... eu queria dizer... a todos vocês... que o importante para resolver o trânsito... é investir no transporte público... e transporte público demanda TEMpo... para se construir... são proJEtos grandes... licitações grandes... a começar o investimento no meTRÔ... depois de TRINta anos... na MInha gestão... a prefeitura VOLtou a investir no metrô... iremos até o final do ano... a ex-prefeita sempre questiona... há uma semana atrás eram trezentos milhões... hoje já são quinhentos e três... questiona que iremos investir... serão UM Bllhão de reais::... com metrô e com BOns corredores de ônibus... e BONs corredores... você que está nos assistindo sabe disso... são corredores que tem que ter as faixas isoladas... com áreas de ultrapassagem no ponto de paRAda... sem cruzamentos... isto é... sem interferências... são corredores mais caros... precisam de bons projetos... nessa gestão... iniciamos o Expresso Tiradentes... TRINta e dois quilômetros... centro até a Cidade Tiradentes... está na fase final... a licitação do Celso Garcia... centro... até... Itaim PauLISta na zona norte... zona 
leste... passando por São Miguel e PEnha... e UM na zona sul... provavelmente... a elaboração de um projeto final para o M'Boi Mirim... e um na zona norte... Cet... encontramos a empresa sucaTEAda... cem milhões de dívidas... aliás... tem entrevista da ex-prefeita dizendo que queria acabar com a Cet... recupeRAMOS a Cet... nós não temos preocupação em colocar nome em PLAca... nós temos a preocupação em fazer um trabalho SÉrio... para que a cidade possa... com alGUNns anos... ter resolvido o problema do trânsito... isso não é apenas numa gestão...

L1: vamos à réplica da candidata Marta Suplicy...

L3: primeiro a Cet... que eu já ouvi esse boato... um boato perVERso... que a Cet conosco trabalhava com a SP Trans... trabalhava e trabalhava muito bem... que a Cet é o instrumento PRINcipal... para a gente conseguir fluir o trânsito aqui na cidade de São Paulo... agora... candidato Kassab... você critica os meus corredores... agora eu pergunto para você... que corredor você fez?... você prometeu CIN-co... e não fez nenhum... não fez nem com ultrapassagem e nem sem ultrapassagem... simplesmente... não FEZ corredor... não FEZ... e a população de São Paulo... sofre MUlto com isso... por que não FEZ?... porque não era a sua prioriDAde... você não está nem aí com as peSSOas... não está nem aí com as pessoas que tem que usar um correDOR... para chegar no traBALHO e poder dormir meia hora antes... poder mais um so... um sonho... poder ficar com o seu filho... você não se incomoda... senão você teria feito... feito corredor... agora fica apresentando um cheque de metrô... que poderia ter sido dado ano passado... ou ano retraSADO... não deu... fica aí com esse cheque de metrô toda HOra... e as pessoas perguntando... cadê o corredor que havia prometido?... o Celso GarCIA... há QUAtro A-nos o corredor já estava... já estava pronto para ser começado... você ainda está na licitação do correDOR... QUAtro anos... não fez neNHUM... e nós fizemos MUltos corredores na cidade... DEZ corredores não é pouco... DEZ terminais não é pouco... porque transporte... para mim... é PRI-o-ri-da-de...

L1: um minuto para a tréplica de Gilberto Kassab...

L2: Marta... ratifico aqui meu compromi::sso... de na futura gestão... concluir cinco corredores... esses dois... e mais três... portanto... é importante sempre falar a verDAde... em relação ao metrô... você está muito incomodada com os cheques... é lógico... porque você vivia dizendo que... ficou três meses dizendo que nós NÃO íamos transferir recursos para o estado... quando eles acontecem... você fica estressados... é evidente... porque... você fica mal com o eleitor... você estava afirmando que não tinham recursos... tem recursos... nós NÃO fizemos recursos se não temos recursos em caixa... porque nós temos res-pon-as-bi-li-da-de... PLAnejamento... VAmos continuar investindo no metrô... NA próxima gestão... MAis um Bllhão... inclusive já tem duzentos e cinquenta milhões no orçamento do ano que vem... e continuar fazendo BONS corredores de ônibus... não podemos é ter pressa para inaugurar de qualquer jeito... um corredor que depois não vai funcionar... demora?... paciência... o próximo prefeito... se Deus me permitir... serei eu... vai inaugurar...

L1: ok... você está assistindo pela Rede Record... ao debate decisivo entre os candidatos que vão disputar o segundo turno da eleição... para a prefeitura de São Paulo... nós vamos a mais um intervalo e voltaremos em TRÊS minutos... eleições dois mil e oito... ((aplausos))... o voto na Record...

((vinheta de intervalo comercial))

L1: esse é o debate decisivo para a escolha de quem vai comanDAR a cidade de São Paulo pelos PRóximos QUAtro anos... numa transmissão da Rede Record... com cobertura da Record News e da Rádio Record... o debate também pode ser 
acompanhado pelo site da rá/... da Record... no endereço... www.rederecord.com.br... estamos dando início ao terCEIro bloco... a regra... é a seguinte... cada uma das jornalistas... ALternadamente... escolherá um candidato a quem fará a sua pergunta e pedirá que seu concorrente coMENte a resposta... 0 candidato que responder terá direito à RÉplica... os tempos são os seguintes... pergunta da jornalista... TRINta segundos... resposta... DOis minutos... comentário... um minuto e quinze segundos... RÉplica... um minuto... CAda jornalista fará DUas perguntas... nós começamos com a pergunta de Adriana Araújo...

L4: (a pergunta) agora vai para a candidata Marta Suplicy... candidata... a senhora coMEçou essa campanha lideRANDO as pesquisas... enquanto o seu adversário Kassab aparecia em terCElro lugar... já a última pesquisa lbope indica agora que a senhora tem trinta e nove por cento das intenções de voto contra... cinquenta e um por cento do seu adversário... o que deu eRRAdo... na sua campanha?...

L1: puxa vida... acho que não deu errado... nós estamos ainda sem urna... urnas abertas... eu acredito que no primeiro TURno... da eleiÇÃO... nós tivemos TOdas as candidaturas batendo em mim porque tava na frente... aí nós passamos para 0 seGUNDO TURno... onde tá... estão sendo feitas as acomodações... e esse debate tem a sua importância porque... é o debate da ÚLtima camPAnha... da última seMANA da campanha... é o priMEIRO debate... e aqui nós vamos ter a chance de falar as propostas... eu quero dizer para vocês... que eu me acredito... eu acredito que nós temos muita CHANce de fazer outro tipo de governo do que está acontecendo hoje na gestão Kassab... eu tenho MUlta experiência... como eu disse... fiz MUltos aCERtos... nessa cidade... com MUlto pouco recurso... fiz eRROs... e eRROS que NÃO cometerei novamente... tenho esTUDOS... agora... para desoneRAR de triBUTOS o cidaDÃO de SÃO Paulo... e teNHO PLAnos ouSAdos... quem foi capaz de criAR... essa operação Água EspralAda... para ter dinheiro para fazer a ponte estaiADA... para fazer os túneis do NAda... é capaz de fazer muita coisa... fui capaz de internacioNALMENTE... buscar reCURsos para essa cidade... que fazia parte das GRANdes ciDAdes do MUNdo... particiPAva da rede metrópoles... trouxe a Urbes para cá... trouxe a Unctad... grande evento da Onu... nós temos a capacidade de criAR... de fazer essa cidade ser GRANde... de acompaNHAR o crescimento do Brasil... que hoje o presidente Lula coLOca esse crescimento do Brasil num pataMAR que nós não Tínhamos... há muito tempo... e São Paulo não está acompanNHANdo esse patamar... e eu tenho condição de fazer São Paulo acompanhar... TEnho condição de trazer investimento para a ciDAde... de levar investimentos para regiões mais caRENTES... TEnho condição de fazer qualfiCAÇÃO... como fiz na Cidade TiraDENTES... quando criei a esCOLA de saÚde... e o hospital Tiradentes do lado... eu tenho condição de penSAR a cidade... pensar as peSSOas nessa cidade... pensar a qualificação para quem tem menos... por isso propus a qualificação profissional nos CEus e por isso eu tenho certeza... que essa cidade seria MAis humana... e POde ser mais humana... quando as urnas se abrirem... no dia dezesseis...

L1:

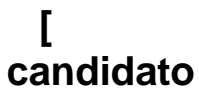

Kassab tem um minuto para comentar...

L2: na medida em que a campanha foi se desenvolvendo... o eleitor pode se recordar do que foi o governo da Marta e conhecer o nosso governo... e evidentemente ele começou a avaliar... de uma maneira MUlto positiva... e temos hoje a felicidade de ser reconhecidos como um bom prefeito... por exemplo... na época da Marta tinha a taxa do lixo... agora não tem... na época da Marta tinha 
injustiça na taxa de iluminação... agora não tem... na época da Marta tinha fraude na catraca... agora não tem... na época da Marta tinha escola de lata... agora não tem... na época da Marta tinha noVENta e SEis obras paradas... agora não tem... na época da Marta tinha atraso na entrega do uniforme escolar... agora não tem... na época da Marta tinha fila de credores para receber na porta da prefeitura... agora não tem... na época da Marta tinha coBRANça pa/... pra pavimentação de ruas de terra... agora não tem... é evidente... que tudo isso... proporcionou ao eleitor... avaliAR a gestão... e ao avaliar a gestão... ele começou a entender a imporTÂNcia da continuidade deste governo... é um governo que faz MUlto pelo social... que melhorou a qualidade da saúde pública... e do ensino público... portanto eu queria dizer que:.... POR coerência... no próximo governo nós vamos dar continuidade a esse PLAno de governo...

L1: candidata... a senhora tem um minuto para a réplica...

L3: que interessante Kassab... TUdo o que você ciTOU... são as coisas que eu fiz para essa ciDAde... o uniFORME... quem criou fui eu... você entrega tamanhos diferentes... no verão... os do inverno... quando você fala da caTRAca... eu fico pasma... porque quem fez o bilhete úNIco... que pôs a catraca... e permitiu à essa população ter um transporte decente... fui eu... você tirou foi beneFícios das pessoas... e eu vou por de novo... direito de recarregar na caTRACA... porque isso que você fez... é uma malDADE com as pessoas mais pobres... que é o que você gosta de fazer... você maquia as coisas... quando a gente vai ver por exemplo essa situação da catraca... você vê que você fala da fraUde... mas você foi retirar o direito... que a pessoa que VAI recarregar na caTRACA... ela só tem aquele dinheiRINHO... Kassab... aquele dinheiRInho com-ta-do... para fazer aquela viagem e pegar duas conduções... com o que você fez... você obriga a pessoa a deSCER do Ônibus... e andar a pé porque ela tem di/... dinheiro para mais... e também o direito que você deu de três horas... você tirou estudantes e vale-transporte... o que tem nessa cidade de avanço sociAL... fui eu quem FIZ...

L1: tempo esgotado... candidata... vamos à pergunta da jornalista Cristina Lemos...

L5: pergunta dirigida ao candidato Gilberto Kassab... senhor Kassab... no primeiro turno... o senhor teve VÁrios atritos com o candidato Geraldo Alckmin... que até chegou a acusá-lo... de mudar de LAdo constantemente... de ser diSSImulado... e agora o senhor TEM o apoio de Geraldo Alckmin... essa situação não o constrange?...

L2: é evidente que não... o segundo turno é OUtra eleição... no segundo turno... seja ele o governador Geraldo Alckmin... seja ele qualquer eleitor... que não votou na Marta... nem em mim... ele tem que definir QUEM é o melhor candidato dos dois... e o Geraldo Alckmin... com muita clareza... se posicionou... ele acha... a minha candidatura... melhor para São Paulo... e é meLHOR por que?... é melhor... volto aqui à listinha... porque no tempo da Marta... não tinha Ama... agora tem... na época da Marta... não tinha dois professores em sala de aula no primeiro ano... agora tem... no tempo da Marta... não tinha Expresso Tiradentes... anDANdo... agora tem... não tinha dinheiro para o metrô... agora tem... um bilhão... não tinha Ama especialidade... agora tem... não tinha esse TANto de asFALTO e recapeaMENTO... agora tem... recapeAmos... o equivalente... a CINco ÚLtimas gestões... pavimentação que nunca foi feita na cidade de São Paulo... não tinha a central de medicamentos... agora tem... não tinha remédios nos postos... agora tem... não tinha remédio em casa... agora tem... não tinha Atendimento Médico Domiciliar... agora tem... não tinha leite nas férias... agora tem... não tinha bilhete Amigão aos domingos... agora tem... não tinha bilhete-único de três horas... agora 
tem... não tinha Cidade Limpa... agora tem... não tinha Virada Cultural... agora tem... não tinha bingo lacrado... agora tem... não tinha quebrada cultural... agora tem... não tinha prova São Paulo... agora tem... não tinha o centro... cultural... da... juventude... que nós homenageamos a nossa querida primeira dama Ruth Cardoso... essa semana... não tinha posto de gasolina fajuta... vendendo gasolina... agora está fechado... ((aplausos))... não tinha clube escola... agora tem... não tinha Virada Esportiva... agora tem... não tinha Nota fiscal eletrônica... agora tem... rodízio de caminhão... agora tem... não tinha caça-níqueis fechados... agora tem... não tinha proibição de comércio escolar... eh... irregular... agora tem... enfim... são tantas coisas que fizeram o ex-governador definir pela nossa candidatura... é uma gestão melhor e será...

L1:

[

L2:

L1: Marta Suplicy... ((aplausos))...

L3:

agora...

L1: volto a solicitar a plateia... que não prejudique o debate com manifestações... por favor...

L3: agora tem prefeito que não sabe dizer nem o que fez... né?... tem que ler... também notei... ((risos))... bom... eu quero dizer pra vocês... ((aplausos))... eu quero dizer pra vocês... que nós vamos... no transporte dessa cidade... fazer uma coisa... PRA vaLEr... quando eu era ministra DO turismo... eu levei para o presidente Lula um PLAno de ação para TOdas as capitais que iam ser... Copa do Mundo em mil novecentos e catorze... e TEnho em São Paulo... mobilidade urBAna... nós não vamos construir CINco corredores NÃO... Kassab... nós vamo/... nós vamos construir duzentos e vinte e oito quiLÔMETROS... de corredor de ônibus... porque a NÓS... imPORta como PRloridade... o transPORte... para peSSOa... que MAis preClsa... e vamos fazer meTRÔ... SIM... porque já disse que se eleita prefeita eu vou levar quatrocentos e oitenta milhões... por Ano para o metrô... mais do que o seu um bilhão agora... que nem foi entregue... e você nem pôs no orçamento o resto... e nós vamos levar o metrô para a perifeRla... porque nós vamos levar o reCURSO... vamos sentar e conversar... como conversei com o Alckmin... para levar o metrô da linha quatro até a Vila Sônia... onde não estava estabelecido... e ele aquiesceu que fosse até lá... e nós vamos levar para a Vila Nova CachoeRINHA... para a LApa... pro Jardim Ângela... M'Boi MiRIM... para SapoPEMBA... para a Vila Maria... porque a periferia dessa cidade tem que ter meTRÔ...

L1: um minuto para o candidato Kassab...

L2: o importante é que o prefeito de São Paulo... e sua gestão... priorizem ações que favoreçam as pessoas mais pobres... que priorizam ações que melhore a qualidade de vida dos paulistanos... mas principalmente... dos mais humildes... investimento no atendimento público de saúde... e fizemos isso com bastante eficiência... com bons resultados... a criação das Amas... a entrega de dois novos hospitais... depois de dezoito anos... o Remédio em Casa... a Mãe Paulistana... ações no ensino público... acabamos com as salas de lata... com as escolas de lata... reformamos TOdas as escolas da rede pública... va-lo-ri-za-ção dos servidores... de uma maneira geral... tivemos a oportunidade... no que diz respeito aos servidores da saúde e educação... aprovar um novo plano de cargos e salários... e... continuaremos apoiando os servidores na próxima gestão... enfim... o governo tem que estar voltado para os mais humildes... 
L1: vamos agora a pergunta de... Adriana Araújo...

L4: pergunta para a candidata Marta Suplicy... candidata... na última campanha para a prefeitura de São Paulo... a principal proposta da senhora... ou uma das PRINcipais... era a criação do Ceu Saúde... projeto inclusive que era criticado pelos seus adversários... agora na atual campanha... a senhora não fala mais do Ceu Saúde... por que?... a senhora deSIStiu desse projeto?... e por quais razões?...

L3: não... o Ceu Saúde foi projetado... para aquele ni/... para aquela instância em que nós estávamos... depois de arrumar o básico na saúde... recuperar os hospiTAIS... começar o piloto do Remédio em CAsa... começar o programa de Saúde da Família... já ter oitoCENtas equipes... então nós arrumamos o básico e... estávamos nos preparando para dar o grande salto... que seriam exataMENte... as especialidades MEdicas e... os exames de iMAgem... o Ceu Saúde seria isso... seria até maior... seria um pouco como é o Quarteirão da Saúde... que foi inaugurado agora em Diadema com TANto sucesso... e o pessoal que fez todo o planejamento do nosso Ceu Saúde aqui... não pode executar porque eu perdi a eleição... e foi fazer agora em Diadema e é uma beleza eu fiquei morrendo de inveja... eu confesso... MAs a aqui a opção do governador Serra... no momento... foi fazer as Amas... pra pronto-atendimento... as Amas atendem mas não resolvem o problema... que uma pessoa chega com uma pressão alta... uma pressão alta... ela é medicAda... vai para a casa... mas depois o especialista não existe... então nós vamos pegar todas as... as portas de entrada... que é a AMA... que é o Ubs... e que é o programa Saúde da Família e colocar mais médicos... e fazer a poliCLÍNICA... que vai ser uma em cada subprefeiTURA... e ela vai ter VINte e três especialiDAdes... e vai ter... também... os exames de tipo ressonância... mamografia... tomografia... que hoje a pessoa não consegue arrumar... mas ao mesmo tempo... um salto importanTíSSIMO... que NÃO foi dado pela gestão do Kassab... e que nós teríamos feito de primeiRíSSIMA... era utilizar o software que deixamos... para informatizar toda a saúde... porque... agora você chega numa Ama... numa Ubs... o médico não tem o teu fichário... não sabe o teu prontuário... e ele não tem como marcar um exame que você necessita... isso tem que ser uma das PRIORIdades que nós vamos fazer... e aí... conseguir fazer... essa eh o/... as policlínicas para responder essa demanda de médico especialista e exame... que é o que eu mais escuto... por onde eu ando na cidade...

L1: um minuto e quinze segundos para o candidato Gilberto Kassab...

L2: pelo que eu entendi... a ex-prefeita... não está apresentando o Ceu Saúde nessa campanha... porque ela entende que avançamos MUlto na saúde... e falta um pouco para ser feito... é verdade... avançamos muito e sempre digo... saúde tem que melhorar sempre... e eu tenho SEMpre... o cuidado... de mostrar o que fizemos... e mostrar o que faremos... e o que deixamos de fazer... em relação à policlínica... que a ex-prefeita apresenta aqui como proposta... eu queria dizer que nós já estamos fazendo... depois de CENto e quinze Amas... no início da campanha eram cento e dez... nós estamos agora implantando as AMAs Especialidades... que são as AMAs voltadas ao atendimento... às consultas com especialistas... isso depois de entregarmos dois novos hospitais... e de estarmos preparando a construção de três novos hospitais... com esses equipamentos contratamos mais de TRÊS MIL médicos... informatizamos a rede:.... criamos... como eu disse agora pouco... vários programas... o Mãe Paulistana... o Remédio em Casa... e diversos outros... que melhoraram a qualidade do atendimento Público de saúde... mas ainda não está do jeito que eu quero... na próxima gestão... vamos continuar avançando... 
L3: as AMAs avançaram no PRONto-atendiMENto... mas esTÁ... Kassab... igual-zi-nho... a dificulDAde de MARcar um exame com um especialista... voCÉ que esTÁ em CAsa... e procurou um cardiologista... quantos meses você está tendo que esperar para arrumar esse cardiologista?...você que está em casa me ouvindo... e quer um exame de ressonância... QUANtos meses para ter um exame de ressonância?... então... o esTADO que nós deixamos... que era para fazer esses CEUs Saúde... que agora nós vamos fazer as policlínicas... que são menores... mas vão atender... essa... esse... essa dificuldade... vocês não deram um salto... vocês fizeram um pronto-atendimento com a Ama... e não adianta ficar falando... cento e trinta AMAs... noVENta e nove dessas AMAs... SÃO Ubss... e PARte delas... que eu consTRUÍ... é isso... nós vamo/ acabar com Ama?... NÃO... estão lá... fazendo pronto-atendimento... é uma iniciativa que a população está sendo atendida... mas é parCIAL... ela não resolve o problema... voCẾ resolVEU o problema da saúde que podia ter resolVIdo... eu dei um SALto eNORme... imaginou se você tivesse receBldo aquele MAR de gafanhoto que eu recebi?...

L1: vamos a pergunta da jornalista Cristina Lemos...

L5: pergunta dirigida ao candidato Gilberto Kassab... senhor Kassab... em virtude da crise financeira internacional... nós devemos enFRENtar... um período de BAlxo crescimento... de inFLAção... e talvez de reajuste de combusTível... mesmo assim... o senhor reaFIRma... que NÃO preTENde reajusTAR as passagens de Ônibus... nesse caso... o setor será sacrificado?...

L2: a pergunta é muito importante... diante da crise internacional... e eu posso aqui reaFIRmar o meu compromisso de NÃO aumentar as passagens de ônibus no ano que vem... inclusive... na PEça orçamentária encaminhada à Câmara Municipal... já CONSta um recurso para evitar o aumento da passagem de ônibus... eu queria dizer... inclusive que... nesse peça orçamentária encaminhada à Câmara Municipal... já consta lá um crescimento do Plb reduzido... em relação ao próprio crescimento do Plb do Governo Federal encaminhado ao Congresso Nacional... até porque... o nosso orçamento quando encaminhado... já... convivia com a crise internacional... então eu estou MUlto tranquilo em relação ao nosso orçamento... as suas condições de arrecadação... e teremos... a tranquilidade graças a boa saúde financeira da prefeitura... de oferecer ao paulistano... a oportunidade de ficar TRÊs anos sem aumento de passagem de ônibus... agora em novembro... vai fazer dois anos que a passagem não é aumentada... isso é inédito na história da cidade de São Paulo... ficaremos mais um ano...

L3: bom... eu quando governei a cidade de São Paulo... foi com MUlto POUco... dez Blhões... a menos... por ano... do que agora o governo Kassab... e porque o Brasil está realmente... crescendo... e a receita da cidade aumentou TANto... nós conseguimos dar um... um SALto extraordinário... no transporte... nós conseguimos... também... ter uma avaliação do transporte... no final da nossa gestão... de sessenta e um por cento de bom e ótimo... e DEZ por cento só de ruim... então realmente... a partir do que eu tive para traBALHAR... nós conseguimos ter capacidade de planeJAR... capacidade de invesTIR... e agora 0 que eu vou fazer... eu não vou aumentar a passagem de ônibus em dois mil e nove... e vou sim... fazer... duzentos e vinte e oito quilômetros de corredor nesses QUAtro anos... por que?... porque o corredor faz o trânsito flulR... ele leva uma pessoa que mora a uma distância... como a zona sul que... quer ir para a zona leste... ir na metade do tempo... nós temos que ter essa percepção... tem que ter prioriDAde... e não dizer... como disse o Kassab... que vai fazer cinco corredores... eu fico PASma... porque parece que até agora... não perceBEU a importância dos corredores na cidade de SÃO Paulo... tá lá o Celso GarCIA... 
há QUAtro anos esperando para ser construído... e não construiu... tá lá... o Expresso TiraDENTES... que é o tal do Fura Flla... que está lá e não foi construído...

L1:

tempo esgotado...

L3:

e não chegou

na Cidade Tiradentes...

L1: o candidato Gilberto Kassab tem um minuto...

L2: eu... insisto aqui em afirmar... que estou muito tranquilo em relação ao nãoaumento da passagem de ônibus... essa tranquilidade é muito importante que o paulistano... em especial... o usuário do transporte público tenha... quero aqui... registrar os eNORmes benefícios que a nossa gestão... ofereceu ao usuário do transporte público... o bilhete-único foi ampliado para a rede de trens... à rede de metrô... ainda com o nosso... então prefeito José Serra... o bilhete único... agora... recentemente... teve o seu tempo... aumentado... de duas horas para três horas... a implantação do Amigão... aos domingos o bilhete-único vale oito horas... a elaboração de projetos de corredor de ônibus como devem ser feitos... sem cruzamentos... com área de ultrapassagem em ponto de parada... nós temos já dois corredores de/... definidos... e o nosso corredor Celso Garcia não é o corredor Celso Garcia que a ex-prefeita aqui menciona... é o NOvo Celso Garcia... com essas características...

L1: tempo esgotado... terminamos assim o terceiro bloco do debate decisivo entre Marta Suplicy e Gilberto Kassab... vamos a mais um intervalo e voltamos em três minutos... eleições dois mil e oito... ((aplausos))... o VOto na Record...

((vinheta do intervalo comercial))

L1: você acompanha ao vivo pela Rede Record... com cobertura da Record News... o debate decisivo entre Gilberto Kassab e Marta Suplicy... os dois concorrentes à prefeitura de SÃO Paulo no segundo turno... o debate também pode ser acompanhado pelo site da Record no endereço www.rederecord.com.br... nós vamos iniciar o QUARto bloco do debate com a seguinte regra... cada candidato fará de forma ALternada duas perguntas a seu concorrente... começando por Marta Suplicy... o candidato que perguntar terá direito à RÉplica... o candidato que responder terá direito à TRÉplica... os tempos... pergunta... um minuto... resposta... DOis minutos... réplica... um minuto e quinze segundos... tréplica... um minuto... a candidata Marta Suplicy tem um minuto para formular a sua pergunta...

L3: Kassab... no debate anterior... eu formulei uma pergunta falando sobre a lei do projeto urbano... do pré/... pedágio urbano... que você enVlou... à Câmara... e eu vou ler aqui essa lei... que a implantação do sistema de tráfego tarifado... projeto quinhentos e vinte e quatro... você:: tra/... tráfego tarifado... você sabe que significa... pedágio urbano... você vai pagar uma TAxa... para sair de casa... então a minha pergunta... Kassab... é... nós temos o Kassab que enviou esse projeto... e que depois no deBAte anterior disse que não era bem assim... que foi um erro... pediu desculpas... falou que não era... e... mas não ficou bem explicado... porque o da propaganda... diz que NÃO... VAi... fazer pedágio... então a minha pergunta é muito singela... você é a favor do pedágio urBAno... ou você é CONtra o pedágio urBAno?...

L2: a ex-prefeita é TRAUmatizada com taxas...

L3: mais respeito... candidato...

L2: eu quero aqui... eu quero aqui registrar... que a ex-prefeita cometeu TANtos equívocos com taxas na sua gestão... que ela tem muito incômodo com o tema 
TAxas... tinha até um apelido... na sua gestão... os vereadores a apelidaram... e até hoje ela é conhecida por esse apelido... portanto... o que eu quero aqui registrar... e tenho credibilidade para isso... porque em nossa gestão... TOdos os compromissos que ela assumiu... ela honROU... é que NÃO VAmos implantar o pedágio urbano na cidade de São Paulo... enquanto eu for prefeito... não terá pedágio... diferentemente da ex-prefeita... que tinha uma série de propostas e promessas... quando assumiu... a prefeitura... prometeu que ia entregar novos hospitais... não entregou... prometeu que ia valorizar os servidores... não valorizou... conforme o compromisso... prometeu que ia acabar com as escolas de lata... não acabou... prometeu que ia acabar com as salas de lata... não acabou... a saÚde em São Paulo... estava em frangalhos... basta se recordar:: dos jornais da época... o Nível do atendimento público de saúde... o lbope... recentemente... atestou que os nossos serviços... tinham uma excepcional aceitação junto aos... uSUÁrios... porque a ex-prefeita omite que a pesquisa lbope é junto aos usuários... que é o que interessa... as duzentas e quarenta mil mulheres que participaram do Mãe Paulistana... dão nota NOve vírgula três... as cento e vinte mil famílias que participaram do... que participam do Remédio em CAsa... nota NOve vírgula quatro... e tantas outras excepcioNAIS avaliações do lbope... em relação a todos os NOvos serviços da saúde... portanto... temos credibiliDAde... e posso tranquilizar a você... Marta... o eleitor acredita nas nossas propostas... e ele sabe que NÃO terá pedágio urbano... portanto... respondendo a sua pergunta... NÃO teREmos pedágio urbano... na minha gestão...

L3: olha Kassab... eu vou dizer ao eleitor que ele está dando um cheque em BRANco... porque além de você ter mandado esse... esse projeto de pedágio urbano... e depois dizer que não foi... que foi um erro etc.... tem um OUtro também... que nesse projeto... o outro... é o sete zero um... que você assiNOU... e coloca o seguinte... que passa para o estado a operação das marginais Pinheiros e TieTÉ... e das novas pistas segreGAdas... com cobrança de pedágio... palavras do projeto entre aspa... "as concessionárias serão remuneRAdas... mediante a exploração de peDÁgios... instalados em pistas segreGAdas... a serem implementadas em acréscimo àquelas já exisTENTES... nos sistemas viÁrios... objeto da... concessão..." aLÉM desse outro projeto... tem MAis UM... que foi mandado agora em seTEMbro... aí eu fico realMENte... não sei se PASma ou indigNAda... porque esse foi mandado pelo SEU Líder... vereaDOR ApoliNÁrio... foi mandado agoRInha... em setembro... e diz o seguinte... que é o projeto quiNHENtos e noventa e seis... coBRANdo QUAtro realS para a populaÇẪO sair de CAsa com o caRRO... agora você quer enganar QUEM?... me diga... e quanto vai custar o seu peDÁgio...Kassab... FAle a verDAde... por favor... porque as peSSOas... em vista de três coisas difeRENtes... e essa é DE seTEMbro... elas realmente estão com dificuldade de acreditar no que você fala... L1: RÉplica do candidato Kassab... de um minuto...

L2: Marta... eu não comando os vereadores... cada um tem o direito de apresentar o proJEto que quer... estou dizendo que comigo prefeito... não haverá pedágio... inclusive eRROU... o líder do partido Apolinário... porque isso é iniciativa do executivo... despesas... o vereador não pode apresentar projetos... portanto... estou muito tranquilo em relação a isso... não é porque é vereador do meu partido que eu não vou discordar... por exemplo... você não discordou do menSAlão... você ficou do lado... até hoje não vi neNHUma CRítica de você ao DeLÚBIO... ao Zé DIRCEU... ao SilVINHO... eu discordo...

L3:

direito de

resposta... 
L2: $\quad$ eu discordo... eu discordo do... eu discordo do vereador Apolinário... ele errou ao apresentar esse projeto... mas é um direito dele... estamos numa democracia... e em relação à pedágio urbano... eu quero aqui relembrar a todos... que quando você encaminhou o Plano Diretor... e que foi aprovado... você continha no Plano Diretor o pedágio urbano... portanto... ao nosso... eleitor paulistano que está nos acompanhando... vamos recuperar o PLAno Diretor que a Marta Suplicy aprovou na Câmara Municipal... e vocês vão ver que o Plano Diretor que a Marta Suplicy aprovou lá...

L1:

fim...

L2:

[

L1:

fim do seu tempo... candidato... esclarecendo... candidata Marta Suplicy... não há motivo de direito de resposta porque não houve injúria... calúnia ou difamação nessa... nessa sequência... ((aplausos))... de acordo com... orientação dos nossos advogados da Rede Record... agora é a vez da pergunta de... do...

L3:<smiles>I[V]I</smiles>

L1: candidato Gilberto

Kassab...

L2: eu queria aqui... relembrar... que os nossos serviços... criados na nossa gestão... tem sido MUlto bem avaliados pelo usuário... mas uma vez... relembrando as pesquisas do lbope... relembrando a satisfação dos pais de alunos... das mães de alunos... dos alunos... com o leite sendo entregue doze meses por ano... com a reFORma das escolas... a SAtisfação dos professores... dos médicos... dos parCElros que hoje conosco tem a responsabilidade de administrar a saúde da cidade de São Paulo... eu deFENdo as parcerias... mas defendo também os servidores... eu defendo a Usp... a Unifesp... a Santa Casa... o Albert Einstein... o Sírio-Libanês... eu tenho... a tranquilidade de vir aqui... e falar... COM os parceiros e os servidores valorizados... melhoraram as condições do atendimento público de saúde... e também... estamos investindo mais... Marta... você construiu os dois túneis... você construiria de novo os dois túneis?... SIM ou não?...

L2: $\operatorname{sim} . .$. evidentemente porque eles ajudaram MUlto a população da cidade de São Paulo... Kassab... como eu expliquei... eu tinha uma cidade de-vas-TADA... e o que é que eu fiz?... eu fui tentar arrumar o recurso de todas as maneiras... e para GRANdes obras... eu consegui... e consegui com muita criatividade porque nos inv/... invenTAmos essa venda de espaço aéreo... o Cepac... quea gente pôde fazer a operação urbana... com esse recurso da Água EspralADA... é que você conseguiu fazer a continuação da Ponte EstalAda... então... com a... a operação urbana e a Ponte EstalADA... nós também propusemos a Roberto Marinho... que você não FEZ... porque podia ter FElto... transformar o Jardim Edith... que é uma favela... numa jardim de verDAde... para as pessoas morando aLI... e os TÚneis foram obras que eu me orGULHO... porque... aquilo era uma operação urbana... igual a da/ Água Espraiada... eu não tinha dinheiro do orçamento... e quando você diz que eu fiz túnel em bairro rico... a população pobre sabe... eles sabem para 
quem que eu trabalho... tanto é que você vê no mapa eleitoral... ninguém ali acha que eu fiz túnel em bairro rico... aqueles TÚneis... eles benefiCIAM... TOdas as pessoas que vem da zona sul e vão para o centro... para a leste... ao mesmo TEMpo... eles também beneficiam as pessoas mais ricas que moram no Morumbi... os dois túneis foram feitos nos lugares certos... e NÃO utilizaram... e você está canSADO de saber... mas a-DO-ra... fazer desse jeito... dizendo que eu usei um dinheiro para... em bairro rico... invés de fazer hospital... o hospital... nós iniciamos... deixamos quase pronto o Tiradentes... como a população da Cidade Tiradentes recoNHEce... que me deu sessenta e dois por cento de seus VOtos... enquanto não foram... acho que quinze ou doze para você... e de M'Boi Mirim é a mesma coisa... eu tive sessenta e dois por cento dos votos... e você... onze por cento... então... eu consTRUí... os hospitais que tinham que ser iniciados aqui em São Paulo... eu fiz a operação urbana que necessitava e... numa prefeitura deixada faLlda... por você... e por Pitta... eu consegui ter um bom desempenho...

L1: réplica do candidato Kassab...

L2: por isso que o debate é importante... existe uma diferença entre as minhas propostas e as propostas da candidata Marta... eu NÃO faria esse túnel... os dois túneis... eu NUNca vi... em lugar nenhum do mundo... um túnel que acaba num seMÁFORO... num farol... um TÚnel que... corrigido... hoje... chega a custar quatrocentos milhões de reais... um TÚnel aonde os carros... se afogavam em enchentes... inclusive... em uma delas... a ex-prefeita estava em Milão... eu queria diZER... que na minha gestão... eu preferi investir no metrô... e poderia sim... a ex-prefeita... investir no metrô... basta transferir o recurso para o metrô... porque o metrô tinha obras... e ainda tem hoje... na região da operação urbana Faria Lima... essa é a diferença entre as nossas propostas... eu jaMAis faria aquele túnel... não melhorou o trânsito... aCABA num farol... custou MUlto caro... proJEtos errados... tivemos que... investir na recuperação... ou na execução de novas obras para corrigi-lo... e TOdos sabem... porque todos já passaram por aquele túnel... que foi uma obra muito infeliz...

L1: a candidata tem um minuto...

L3: eu tenho CERteza que você não investiria MESmo... você deixaria no banco o dinheiro... abso/... é verdade... é isso que você faz... ((aplausos))... NÃO tem PElto... não tem PElto de fazer... não tem PElto de FAzer... essa é a verdade... Kassab... porque as grandes obras que você fez... foi tudo continuação do que eu fiz... cite UMA obra nessa ciDAde... que você fez... que não tenha sido liciTAda... ou começada por mim... e eu tive a ousadia de faZER... porque na hora em que eu consegui o reCURso... pros TÚneis... já era noVEMBRO... de dois mil e TRÊs... e a alternativa que eu tinha era o seguinte... põe no metrô... não tinha projeto execuTIVO... e se não tem projeto execuTIvo... pela incapaciDAde tucana aLI... você não pode por... porque você sabe muito bem que a operação urbana não permite... e a outra alternativa que eu TInha... era deixar no BANco... e eu pensei MUlto bem... eu falei... vou deixar no banco... o país em recessão... as pessoas sem emPREgo... e aquilo pode DAR uma fluidez no trânsito TÃO boa... eu não vou deixar no banco... eu vou fazer os túneis... eu FIZ... e entreGUEi... e os túneis nunca mais tiveram enchente... a não ser na inauguração quando estava entupido os bueiros... fale a verDAde... Kassab...

L1: tempo agora para a candidata Marta Suplicy... ((aplausos))... VOLto a reiterar... o comportamento da plateia... por favor... TEMpo... tempo para a candidata Marta Suplicy fazer pergunta ao candidato Kassab...

L3: Kassab... na minha gesTÃO... eu consegui fazer o empréstimo do Bld... no centro da cidade... do Banco de Desenvolvimento... e Aí... com esse empréstimo... 
eu fiz muita coisa... eu recuperei o Mercado MuniCIPAL... eu recuperei o Largo do Arouche... eu construí cinco mil moradias no cenTRO... e aí... deixei cem milhões para você... trabalhar... você não uSOu... você está pagando MULta por não utilização do reCURso... não continuou neNHUM dos projetos que tínhamos para a recuperação do CENtro... e ao mesmo tempo falou de um GRANde... MEga projeto na cracoLÂNdia... o projeto da cracoLÂNdia... ontem... eu encontrei uma senhora que me falou que ficou com verGOnha... uma senhora GRÁvida... que tava... foi passar naquela regiÃO... e viu uma pessoa fuMANdo CRAck... CRAck... quer dizer... o proJEto... não saiu do papel... TÁ LÁ... as pessoas fumando CRAck... e você não utilizou um recurso importanTíssimo... uma oportunidade Única... pra ciDAde de SÃO Paulo... recuperar o seu centro... o centro hoje está PIOR do que quando eu deixei... há QUAtro anos atrás...

L1:

[ candidato Gilberto Kassab... tem dois minutos...

L3:

aconteceu com o ( )...

L2: Marta... os recursos que NEM o Pitta... e nem você gastaram... porque você também não gastou... são recursos que não foram gastos porque vocês não tinham proJEtos... e nós tivemos que FAzer projetos em algum casos... em alguns casos... e REformular projetos... em outros casos... REformulados esses projetos... nós estamos investindo em algo que seja bom para a cidade... que de NAda adianta... investir recursos... em maus projetos... citei... agora pouco... a questão dos túneis... é lamentável... em qualquer que seja a regiã/... região da cidade... você gastar quatroCENTOS milhões de reais... corrigidos... em projetos que não melhoraram o trânsito na cidade de São Paulo... dois túneis... e em relação ao centro... em relação ao projeto Nova Luz... é um dos projetos MAis extraordinários da cidade de São Paulo... como disse também... em outra oportunidade... no debate anterior e hoje... eu não estou preocupado em colocar o meu nome em PLAca... os bons projetos... numa cidade... com ONze milhões de habitantes... eles demandam TEMpo... tem fase pra projeto... fase para licitação de obra... fase para implantação... e a Nova Luz... é o NOvo modelo de recuperação e desenvolvimento da cidade de São Paulo... teREmos nesse região... uma nova São Paulo... que servirá modelo para recuperação de OUtras áreas da cidade de São Paulo... nós estamos na FAse final das desapropriações... que é uma fase LENta... até porque o proprietário... ele tem o diREITO de questionar valores... e estaremos sim... dentro de alguns meses... já na fase de CONStrução dos projetos... já temos VINte e sete GRANdes empresas... habiliTADAS a receber os incentivos da Nova Luz... que irão construir as suas sedes nessa região... levando emPREGOS... levando moraDIAS... e fazendo... e mostrando para o paulistano... o QUÃO importante esse projeto é para a cidade de São Paulo...

L3: começa com uma inverdade... dizendo que eu não gastei o dinheiro em quatro anos... esse dinheiro foi... eh... foi... libeRAdo pelo SeNAdo já em dois mil e QUAtro... então eu tive POUco tempo para gastar... e tive muita capacidade... porque enquanto eles ficavam lá discutindo... se ia liberar ou não... nós fizemos os projetos... então demos a contrapartida... fizemos o Mercado MuniciPAL... fizemos... a Favela do GAto... foi com esse dinheiro do Bid... as moradias do centro... foi com esse dinheiro do Bid... o que vocês tiveram... foi uma incapacidade de pens/... de pensar... e de ter a humilDAde de ver os projetos que estavam ali... e contiNUAR... por exemplo... o Mercado MuniciPAL... falta construir as duas torres de alimentação... que vocês não fizeram... o Palácio das 
Indústrias... que ia ser um museu... está LÁ... não fizeram nada... o Palácio das Indústrias... o PARque Dom PEdro... completamente às escuras... você que mora ali perto sabe... abandonado... eu vou recuperar tudo isso... porque a gente tem capacidade de fazer... tem capacidade de planejar... e não fica falando em CracoLÂNdia... porque está zero a Cracolândia... quem vai no centro vê... a Cracolândia agora... ela foi... para a praça da RePÚBLICA... para a... Barra FUNda... Campos Elísios... cês transformaram o CENtro na cracolândia... entende?... e não fizeram nada... está tudo no papel... há QUAtro anos no paPEL... eu TIve esse projeto em SEis meses... e fiz tudo o que eu falei pra vocês...

L1: vamos a TRÉplica do candidato Gilberto Kassab em um minuto...

L2: depois... da manifestação no último debate... da ex-prefeita... em relação a sua visita ao Ceu Vila Formosa... que está sendo construído... eu sempre relevo... nas questões de engenharia... os seus posicionamentos... porque... PAra a engenharia... a ex-prefeita não tem... evidentemente... o conhecimento... precisa ter uma assessoria competente... o projeto Nova Luz é maRAvilhoso... as pessoas que estão me assistindo em casa... e que não o conhecem... precisam conhecê-lo... levará para uma região deteriorada da cidade de São Paulo... multinacionais... grandes empresas... miLHAres de empregos... já temos lá... a sede da guarda municipal metropolitana... já teremos lá... em breve... a SEde da subprefeitura da Sé... VIN-te e SE-te grandes empresas que levarão milhares de emprego... a prefeitura já direcionou... para o projeto... a construção de moradias populares... fazendo com que o emprego... se aproxime da moradia... eu tenho certeza absoluta que aqueles que conheceram o projeto saberão da sua importância para a cidade de São Paulo...

L1: candidato Gilberto Kassab faz sua pergunta agora à candidata Marta Suplicy...

L2: candidata Marta... o seu governo terminou com oiTENta e nove obras paradas... GREves dos educadores dos Ceus... TRINta mil buracos nas ruas da cidade de São Paulo... diversos outros programas que ficaram no papel... eu... e a cidade quebrada... a cidade falida... eu pergunto:: a senhora... a você... Marta... porQUE... a cidade estava falida?... o que faLHOU no seu governo?...

L3: Kassab... se eu fosse acreditar no que você tava falando... eu devia ter ficado em casa... e não concorrido a duas eleições... e não teria essa votação tão expressiva na cidade de São Paulo... as pessoas votam em mim... Kassab... porque sabem o que fizeram nessa cidade... e porque SAbem... o que eu recebi de você... e do PItta... elas SAbem... do BANdo de gafanhotos que tinha diziMAdo o PAs... elas sabem que os hospitais estavam naquela condição... como elas sabem... o CAos que vocês criaram no transporte... e a educação abandonada... então... as pessoas TEM essa consciência... o que elas não percebem alNda... é que os projetos que você se uFAna... são projetos que foram iniciADOS... na MInha gestão... a Ponte EstalAda... que você acha que é o cartão de São Paulo... e que realmente é linDÍSSIMA... e que você não queria faZER... ela foi... idealiZADA... na MInha gestão... os vinte e um Ceus foram idealizados... NA MInha gestão... o Vila Formosa... que está lá parado... que só tem uma placa... agora eu vi que você pôs outra essa semana... e já deve ter manDAdo um MONte de máquina lá para fazer uma terraplanagem... eu posso não ser engenNHEIra... mas boba eu não sou... nem reforma em casa demora quatro meses... como é que você vai entregar um Ceu daqui há quatro meses... que está ainda na terraplanagem?... isso é uma... não dá para acreditar... assim como o Ceu Uirapuru está nos pilares... o Ceu Jaguaré está nos pilares... e eu quero ter o compromisso com você... eu vou acabar os vinte e cinco Ceus que ele não está deixando pronto... e vou fazer mais vinte... vou fazer no Teotônio Vilela... que eu 
fui lá e fiquei muito impressionada com a necessiDADE... vou fazer no Parque das Flores... no Jardim CosmopoLITA... tem alguns que eu já sei até quais vai... vão ser os primeiros... porque as pessoas preCISAM desse instruMENto de inclusão social... que é o Ceu... e que a gestão de vocês não conseguiu perceber isso... o que eu ando na rua... vou... passo nas regiões dos CEus... Kassab... sabe o que eles falam para mim?... nós não temos mais teatro... nós não temos mais FILme... nós não podemos mais ensaiar no Ceu... a hidroginástica dos idosos acabou... é... a comuniDAde não está mais DENtro do Ceu... que vocês não enTEMdem o conCElto... vai voltar comigo...

L1: fim do seu tempo... candidata... ré/... réplica de um minuto e quinze...

L2: é importante... o cidadão que está nos assistindo saber... que quando a exprefeita diz que deixou encaminhado... ela deixou as li-ci-ta-ções realizadas... é uma administração que gostava muito de licitação... até agora eu não entendi porque... DEZEnas e dezenas de licitações... deixou diversos Ceus licitados... diversas obras licitadas... um governo especialista em licitação... o meu governo... é especialista em oBRAS... em redução de custos... em administrar a cidade com austeridade... com eficiência... priorizando os mais pobres... porque:..... é dessa maneira que você respeita o dinheiro público... e tem sido muito gratificante para mim... circular pela cidade... e ter tido uma... estar tendo... uma receptividade tão carinhosa de parte de toda a população... aliás $0 . .$. instituto Datafolha... que dava um número bastante inferior... a ex-prefeita... nessa fase de seu mandato... nos últimos dias... avaliou o meu governo... com ótimo e bom... sessenta e um por cento... isto é... sessenta e um por cento dos paulistanos entendem que ele é ótimo-bom... eu portanto... queria agradecer a você paulistano... e dizer... que é um governo voltado às obras... não à licitações...

L1: um minuto para a sua tréplica...

L3: Olha... nem parece que você entende do que é ser prefeito... para você poder fazer uma obra... você tem que fazer uma liciTAÇÃO... e às vezes tem que desapropriar um terreno... ou você acha que você acabou... e fez o hospital... lá no M'Boi Mirim... se eu não tivesse... primeiro... lutado dois anos na jusTIÇA... pra desapropriar o terreno que era uma situação difícil... não tivesse conseguido fazer a licitação... ah... você acha que teria feito alguma das obras... a Ponte Estaiada... você não conseguiu fazer... aliás não me respondeu... UMA licitação importante nessa cidade... as obras que você conseguiu terminar... fui eu que fiz... olha... gente... fazer licitação... NÂO é fácil... primeiro você precisa saber... licitar 0 quE... que eu não vi neNHUma grande ideia no seu governo... nós criamos o Cepac... que foi esse título que permiTIU... sem onerar o orçamento... fazer a Água Espraiada e a Ponte Estaida... e fazer os dois túneis... o que você fez de criativo nessa cidade?... o que você fez?... eu fiz TANta coisa do nada...

L1: fim do seu tempo... candidata... obrigada... nós vamos a mais um intervalo e voltamos em três minutos... eleições dois mil e oito... o vOto na Record... ((aplausos))...

((vinheta de intervalo comercial))

L1: estamos iniciando o último bloco do debate decisivo entre os candidatos Gilberto Kassab e Marta Suplicy... escolhidos para disputar o segundo turno da eleição em São Paulo... aqui... cada candidato terá DOis minutos para fazer as considerações finais... e pela ordem do sorteio... efetuado na presença de assessores... MARta Suplicy é a primeira candidata... por favor... candidata...

L3: primeiro eu quero agradecer a Tv Record... ao candidato Kassab... a plaTEIA... a jornalistas... mas principalmente a você... eleitor... que está em casa até agora... esse é um deBATE importante... porque você conseguiu ver... uma pessoa que fala exatamente o que ela fez na cidade... de forma TRANSparente... 
não aumenta... não diz que está fazendo... não al/... não acrescenta número... é isso... é isso... agora... eu gostaria que você pensasse nesse momento... porque a eleição... a gente ganha quando abre a urna... e aqui tem pessoas que já votaram nele... já votaram em mim... já votaram nos outros candidatos... e esse é 0 momento fiNAL... eu gostaria que você pensasse que nós estamos vivendo no Brasil hoje... um momento MUlto vibrante... um momento em que o Brasil está cresCENdo... e eu quero que você faça uma reflexão... depois de tudo o que você ouviu no debate... você acha... que o prefeito atual... Kassab... conseGUIU... de FAto... aproveiTAR esse moMENto do Brasil?... essa crê/... esse crescimento do Brasil?... ele conseguiu trazer investiMENtos aqui para São Paulo?... ele conseguiu qualiFICAR os que mais precisam?... ou aquela pessoa de quarenta anos que quer mudar de emprego?... ele conseguiu fazer tudo isso?... eu pergunto para você refleTIR... a outra questão que eu quero coloCAR... é uma questão SIMples... mas que pode acender uma luzinha na sua cabeça... o que de conCREto o prefeito Kassab fez para melhorar a sua VIda?... primeiro... que não tenha sido começado por mim... e depois... do concreto mesmo... quem melhorou o transporte nessa cidade?... e fez o bilhete único que as pessoas hoje ainda agradecem tanto?... quem arrumou a saúde para dar o salto... e que não foi dado ainda... porque não tem os médicos especialistas... quem fez os maiores programas soClais que essa cidade já VIU?... Operação Trabalho... o Começar de Novo... Renda Mínima... todos agora cortados pela metade... eu quero dizer para vocês... se eleita... serei uma GRANde prefeita de::ssa cidade...

L1: nossos agradecimentos à candidata Marta Suplicy... e agora é a vez do candidato Gilberto Kassab... o senhor tem dois minutos...

L2: queria cumprimentar a candidata pela participação... cumprimentar a Rede Record pela realização desse debate... cumprimentar o senhor... a senhora... a você... que nos acompanhou ao longo desse debate... que nos deu a oportunidade... de apresentar as nossas propostas... e que... ao longo dessa campanha... tem acompanhado as nossas realizações... tem tomado conhecimento das imporTANtes transformações que aconteceram na cidade de São Paulo... nesses quatro anos... transformações que... implantaram na cidade de São Paulo... uma Cidade Limpa... uma cidade que hoje não tem poluição visual... transformações que implementaram na cidade de São Paulo a rede de Amas... CENto e quinze Amas que atendem MAis de um Mllhão de pessoas por mês... transformações que... implantaram o MÃE Paulistana... que atenderam já duZENtas e quarenta mil MÃEs gestantes na cidade de São Paulo... o remédio em casa... enfim... o que eu posso dizer a cada um de vocês... é que a cidade melhorou hoje... a cidade avançou na qualiDADE de seus serviços prestados... e tenho a tranquilidade de dizer... que ainda faltam MUltos desafios a serem superados... São Paulo é uma cidade imensa... e nós... TOdos juntos... vamos continuar... com MUlto investimento... MUlta determinação... com MUlto espírito público... superando esses desafios... e resolvendo importantes problemas que ainda não foram ainda resolvidos... o importante é a boa FÉ... é a serieDAde... com o uso do recurso público... é a constituição de uma boa equipe... portanto... a todos vocês... MUlto obrigado... por estarem acompanhando esse debate... e eu queria registrar a alegria de estar participando dessa campanha... quero continuAR a ser prefeito de São Paulo... gosto de ser prefeito de São Paulo... e... peço... a cada um de vocês o voto... peça o VOto... a voCÊ... a seus familiares... aos seus amigos... para que a gente tenha oportunidade de continuar esse trabalho... e a todos vocês... MUlto obrigado e até a próxima... ((aplausos))...

L1: obrigado candidato... chegamos assim ao fim desse debate decisivo... a Rede Record espera ter contribuído para que você eleitor... tenha tido a oportunidade de 
conhecer melhor... os dois candidatos... que pretendem governar a cidade de São Paulo... a transmissão continua ao vivo na Record News... canal quarenta e dois Uhf... com entrevistas... e a repercussão do debate... e a reportagem comPLEta em nossos telejornais... eleições dois mil oito... o VO-to na Record...

((vinheta do fim do programa)) 


\begin{abstract}
ANEXO 4
Programa exibido no dia 24 de outubro de 2008, com duração de cem minutos e quarenta e seis segundos.

L1: Chico Pinheiro.

L2: Gilberto Kassab.

L3: Marta Suplicy.

L4: Rodrigo.

L5: César Menezes.

L6: Alda Marcoantonio.

L7: Verusca Donato.

L8: Aldo Rebelo.
\end{abstract}

((música de abertura))

L1: nos esTÚDIOS da Tv Globo... aqui no BROOklin... na zona SUL de São Paulo... começa agora... o último deDAte do segundo turno... entre os candiDAtos a preFEito de São Paulo... já estão aqui em nossos estúdio... Gilberto Kassab... atual prefeito... candidato à reeleição pelo partido DemoCRAtas... e MARta Suplicy... candidata do Partido dos Trabalhadores... o Pt... UM DEles... será escolhido por você... eleitor... para comanDAR a cidade pelos próximos QUAtro anos... e esta será mais uma oportuniDAde para conhecer as propostas... avaliAR o desempenho de cada um... e voTAR de modo consciente... no PRÓximo domingo... o posicionamento dos candidatos aqui no estúdio... FOl... decidido... por sorTElo... o debate terá CINco blocos... e agora nós vamos conhecer as REgras... o primeiro e o terceiro blocos são de temas livres... os candidatos trocam perguntas sobre os assuntos que quiSErem... no segundo e no quarto blocos... os temas são determinados por sorteio... os candidatos terão trinta segundos para a pergunta... dois minutos para a resposta... um minuto para a RÉplica... e um minuto para a TRÉplica... eles perguntam e respondem o mesmo número de vezes... o candidato sorteado para a abrir o primeiro bloco... abrirá necessariamente o terceiro... o outro candidato abrirá 0 segundo e o quarto blocos... no quinto bloco... haverá novo sorteio para indicar o candidato que iniciará as considerações finais... as regras assinadas por representantes dos candidatos não permitem ofensas pessoais e acusações que atinjam a honra e a dignidade dos adversários... se um candidato se sentir ofendido ou caluniAdo pelo oponente... poderá pedir o direito de resposta... que será analisado por mim... com ajuda da nossa equipe de produção... mas eu tenho certeza que o debate será em alto Nível... e nós não vamos precisar usar esse reCURso... os candidatos não poderão exibir para as câmeras... nenhum tipo de docuMENTO... panFLEto... ou texto... ainda que manusCRITO... as regras também não permitem... que um candidato fale FOra de hora... eu peço a todos os candidatos que estão aqui... em nosso estúdio... que se mantenham em siLÊNcio durante todo o debate para não prejudicar os candidatos e nem aqueles que nos acompanham pela tv... esse silêncio só poderá ser quebrado aGOra... na entrada dos dois candidatos... eu convido... Gilberto Kassab e Marta Suplicy... ((aplausos))... muito bem... vamos então... começar o debate... eu vou sorTEAR... o nome do candidato que irá fazer a PRIMEIra pergunta... sobre o assunto que quiser... o tema é liVRE... o candidato... ou a candidata... vamos ver... o candidato é Gilberto KaSSAb... o senhor tem trinta segundos para fazer a pergunta...

L2: Marta... o seu vice... Hélio Bicudo... disse em seu livro que:: você deixou a cidade falida... quebrada... disse que:: o SErra herdou de você uma cidade 
quebrada... bueiros sem limpeza... dívidas na saúde... na educação... a cidade... um verdadeiro caOS... eu queria que você... falasse um pouco... em relação à situação deixada na cidade... analisada pelo seu próprio vice... Hélio Bicudo...

L3: Kassab... é muito importante... quando você analisa essa situação... VER... como é que ela veio para mim... e o que eu FIZ... como eu terminei... e eu falo com MUlto orgulho como eu terminei... como entreguei esta cidade... pra José Serra e para você... primeiro eu tive as contas aprovadas... pelo tribunal de can/... de contas... tive pela câmara... e tive também aprovada pelo Supremo TribuNAL FedeRAL... então... esta questão das contas... nós poderíamos ficar Anos discutindo os NÚmeros... mas eu acho MAIS importante... discutir... que vocês disseram que estava quebrada... faLIDA... discutir... o quanto vocês tinham em CAlxa... que você NUN::ca contrariou o que eu disse... um Bllhão e pouco em caixa em jaNEIro... e depois... no final do ano... já tinham dois bilhões e meio... agora... o importante é perceber... que o... a cidade que eu recebi... e a ciDAde que eu receBI... foi de voCÊ... voCÊ com Pitta... que acabaRAM com essa cidade... me entregaram a cidade com o PAs... que era aquele programa de saúde priVADO... que estava nas PÁginas de poLÍcia... a educaçÇÃo abandoNAda... a... a... cidade... as PRAças... tudo abandonado... eu... eu... a gente não sabia nem por onde comeÇAR... essa foi a cidade que vocês me entregaram... então... eu lembro quando o Serra começou essa politiCAGEM de diZER... que a cidade estava quebrada... etc.... etc.... eu fiquei:.... eu fiquei pensando... imagina se ele tivesse receBldo... a cidade que eu receBI... que... de voCÊ... isso é o que é o mais sério... de voCÊ... que agora... é prefeito de São Paulo... né?... eu recebi uma cidade... que as subprefeituras que eram... eram regioNAis... as pessoas não lam porque eram centros de coMÉRcio... era essa cidade... com a MÁfia dos fisCAis... as pessoas não podem esquecer o que foi... eu me esforCEl... eu FIZ... eu entreGUEI a cidade em orDEM... CONtas em orDEM... tanto é que vocês tinham dinheiro...

L2: você entregou a cidade com noVENta e seis obras paradas... TÚneis... malfeitos... que nas chuvas... eram vítimas de enCHENtes... Dívidas... que chegaram a dois Bllhões de reais... e... o seu vice... que... assumiu a prefeitura... enquanto... durante dez dias... você estava em Paris... e durante DEZ dias ele pôde observar a cidade... na página duZENtos e quinze do seu livro dizia... "ao assumir o cargo... logo deparei com problemas surgidos em consequência de compromissos financeiros que não estavam sendo cumpridos... REfiro-me... especialmente... à coleta de lixo... à limpeza de bueiros... e sobretudo... aos pagamentos à educação e à saúde... encontrei muito pouca disposição para que se mantivesse a cidade em bom estado... chego a pensar que a intenção era entregar o município... com todas as deficiências possíveis... criando desde logo... dificuldades... para o prefeito eleito José Serra..."

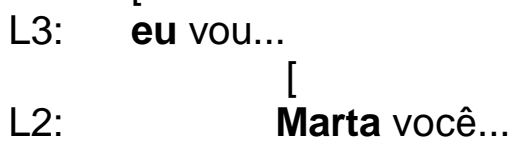

L1: acabou candidato... o seu tempo está esgotado... candidata... L3: eu gostaria de dizer... que eu entreGUEi a cidade com a RadiAL LESte concluída... com a JaCUPÊssego... com VINte e um Ceus PRONtos... VINte e CINco para você faZER ... que não FEZ... cin/... cinQUENta e nove Ubss... eh... construĺdas POR MIM na cidade... você não construlU neNHUma... cento e trinta Amas que você disse que construiu... noventa e nove são divisões de 
UBs... então... fora as creches... as vagas que eu criei... eu criei oiTENta e seis eh:.... creches novas... ah... eu acho que eu entreguei a cidade... TÃO meLHOR... do que eu resp/... receBí... que eu acho inacrediTÁVEL... dizerem... e ficarem falando... sobre como eu entreguei a cidade... se vocês tivesse recebido o que eu recebi... vocês não ousaRlam falar... o que eu consegui fazer... a capacidade que nossa equipe teve de gesTÃO... de planejamento... de buscar dinheiro... de FOra... de parceria priVAda... foi muito grande... e por isso que eu sinto e... vou repetir de novo... eu sinto muito orgulho de administrar a minha cidade e de entregar do JElto que eu consegui entregar...

L1: candidata Marta Suplicy agora faz a SUa pergunta ao candidato Gilberto Kassab...

L3: boa noite Chico... boa noite Kassab... eu vou ler um documento... eu quero saber a sua opinião sobre ele... entre aspas... "deixar os móveis desmontados com antecedência... amaRRAR as portas dos armários e gavetas... desCONgelar a geladeira no dia anterior... desocupar totalmente o fogão... colocar coisas miúdas em caixas... não deixar crianças no caminho... deixar alMOço pronto... pois haverá demora... avisar que vai faltar no serviço..." então Kassab... qual é a sua opiniÃO sobre esse documento... que eu acabei de ler?...

L2: Marta... independente de qualquer que seja o documento que você leu aí... o importante nesse debate é que possamos... fazer um debate sobre São Paulo... as suas propostas... o que nós fizemos... o que faremos nos próximos quatro anos... analisar como encontramos a cidade... no início da nossa gestão... você disse que encontrou a cidade quebrada... falida... nós encontramos ela MAis falida ainda... e hoje a cidade está melhor... hoje avançamos na saúde... avançamos na educação... consTRUÍmos as Amas... consTRUÍmos... dois novos hospitais... na próxima gestão... entregaREmos três novos hospitais... fizemos... um programa de recuperação... com os cuidados da cidade... recuperaÇÃO da manutenção da cidade... hoje a cidade está mais bonita... hoje a cidade tem um projeto... o programa Cidade Limpa... eliminou a poluição visual... hoje a cidade... enfim... está melhor para se viver... hoje as crianças... estudam com mais qualidade nas escolas... hoje... UM MIlhão de pessoas usam as Amas... e segundo o Ibope... avaliam o serviço... com nota acima de nove... hoje duzentas e quarenta mil MÃES... utilizaram o programa Mãe Paulistana... e também... segundo o mesmo lbope... entende que o serviço merece nota acima de nove... enfim... Marta... o que nós podemos afirmar... é que... discutindo a cidade de São Paulo... ponto por ponto... e não com pegaDInhas em pequenos docuMENtos... porque a campanha nós... na campanha nós temos que resPEltar o eleitor... e respeitar o eleitor significa elevar o nível da campanha... significa discutir políticas públicas para a cidade... significa enfim... mostrar... o que fizEmos... e o que faREmos...

L3: Kassab... respeitar as pessoas não é com você mesmo... porque esse... isso que eu acabei de ler... é um doCUMENto... de despeJO... que você manda para a pessoa na VÉSpera... e esse documento FAla... o que eu acaBEi de LEr... no dia seguinte... VAl caCHOrro... gás lacrimoGÊNIO... traTOR... e poLÍcia... esse é o governo que trata assim as pessoas... é o SEU governo... não é pegadinha... nós estamos falando de GENte... estamos falando de seres huMAnos... e quando fala... tira as crianças do caMInho... eu não tiro a criança do caminho... eu coloco a criança no caminho... eu coloco a criança num CEu... eu dou esperança para a criança... e TRAto... as pessoas de forma diferente... que aqui esTÁ... eXAtaMENte... as duas formas de goVERno... uma pessoa que goVERNA... do jeito que você $\mathrm{fa} / . .$. coloca... pegadinha... ou sei lá o que... gás lacrimogênio... e essa carta de despeJO... infame... a outra... que é uma pessoa do diálogo... que 
conVERSA com as pessoas... e é por isso que eu quero voltar a ser prefeita... para voltar a essa/... TRAtar essas pessoas com dignidade... que merecem...

L2: tratar as pessoas que moram em condições inadequadas com dignidade... significa... inVEStir... nas condições de moradia... nós TRIplicamos o orçamento na cidade de São Paulo... no orçamento do ano que vem será mais um bi/... mais de um bilhão de reais... este ano gastamos oitocentos milhões de reais... mais do que o triplo do que você gastou na sua gestão... eu posso dizer que... esse documento... que eu não sei se é verdadeiro ou não é... não é compatível com a nossa política pública de melhorar as condições de moradia NA cidade de São Paulo... fizemos parcerias com o governo do estado... parcerias com o governo federal... e investimos VERba da prefeitura... do nosso orçamento... que melhoraram MUlto... a qualidade de vida de Milhares de pessoas... eu posso dizer... que atendemos... CINco vezes mais pessoas... hoje... nós temos política pública voltada para a habitação... que mostra a prioridade que são reconhecidas a todos... portanto... Marta... não é um documento como esse... que eu nem sei da onde vem... que... vai fazer que o eleitor tome conhecimento da...

[

L1:

candidato...

[

L2: situação da...

L1:

candidato Kassab... o seu tempo terminou... o senhor faz a pergunta agora... o senhor faz a próxima pergunta...

L2: eu... queria... aqui perguntar para a candidata Marta... eh... fazer uma pergunta em relação ao terCEiro turno nas escolas... ela encontrou a cidade de São Paulo... com noVENta mil crianças estudando... no turno da fome... o famoso turno da fome... e deixou a cidade com cento e cinquenta mil crianças estudando nesse turno... eu... queria saber... da candidata... o por que... aumenTOU o número de crianças estudando nesse turno... na sua gestão...

L3: olha Kassab... se em alguma coisa que eu me orGUlho... de ter feito nessa cidade... foi em relação à educação... os professores estavam aBANdonados... os professores não tinham caRREIra... as escolas/... o DÉficit escolar era giGANtesco... e nós nos esforçamos MUlto... nós nos esforçamos muito e conseguimos fazer MUlta creche nessa cidade... eu consTRUí muitas creches... eu conveNIEI muitas creches... fiz muitas coisas para as crianças dessa cidade... não é a TOa... a minha votação nos bairros mais pobres dessa cidade... porque as mães SAbem... o que eu fiz pela educação... e depois eu fiz os Ceus... né?... os Ceus são o antes e o depois na educação em São Paulo... porque eles vão muito aLÉM... Kassab... você nunca conseguiu entender isso... eles vão muito além de um instrumento de educação... eles são um instrumento de educa/... de incluSÃO sociAL... os Ceus são feitos onde a poBREza é TÃO grande... mas tão GRANde... que não adianta nem fazer uma CREche... você tem que dar a possibilidade da criANça perceBER... que existe outro MUNdo... e isso nós fizemos... e nesses lugares... fizemos Emei... fizemos Emef... fizemos creche... demos meRENda boa... de qualidade... que na sua gesTÃO com o Pitta... era de QUINta categoRIA... nós conseguimos dar emenda sauDÁvel... bem compos/... com... nutriTlva para as nossas crianças... e investimos no professor também... na nossa gestão... os professores ade/... fic/... começaram a carreira de Adi... começavam com as crianças pequeninhas... e nós... propiciamos a eles a... o 
magistério... sabe que conseguimos com isso... um aumento de oiTENta por cento nos saLÁrios dos que ingreSSAram na carreira de professor... e para os professores nós demos a oportunidade de fazer uma universidade... paga pela prefeiTUra... mais de três mil aceitaram... e tiveram imediatamente... um aumento de quinze por cento... então nós planejamos muito bem... deixei CENto e noventa e uma escolas FEltas... construÍdas... não faZENdo mas... construídas... e cento e oitenta e seis planeJAdas... para você fazer...

L2: os professores e os servidores sabem... como foram... como foram tratados na sua gestão... o que eu quero lembrar aqui... é que:: uma criança... que fique uma hora a mais na aula por dia... na escola por dia... e quando é eliminado o turno da fome... a... a turma da manhã... a turma da tarde... fica uma hora a mais por dia... isso significa... o equivalente a dois anos a mais de estudo para as crianças... portanto é FUNdamental... você saber PRIorizar na vida pública... e na educação... a prioridade nossa foi acabar com as salas de lata que você deixou... acabar com as escolas de lata que você deixou... e agora acabar com o terceiro turno... com um amplo programa de construção de escolas... e valoriZAmos... os servidores... os professores... como eles nunca foram valorizados... na cidade de São Paulo... portanto... eu tenho MUlto orgulho de nossa ação no ensino público... L3: olha em rela/... sou eu?... em relação às escolas de lata... você CANsa de repetir essas escolas de lata... que foi você quem FEZ junto com o Pitta... e você era o secretário de pla-ne-já-mento... essas escolas de LAta eu... eu fui... não como você... né?... que podia ter resolvido isso na gestão anterior... que o Ministério PÚblico... mas trouxeram as escolas de lata para a MInha gestão... eu desativei... construí onze novas... as outras... eu converSEI com o Ministério PÚblico... porque nossa gestão tinha capacidade de diálogo... e durante dois anos... conseguimos convencê-los a construir escolas de alvenaria naquele lugar... porque eu não ia permitir criança pequeninha andar duas horas de ônibus... por isso começamos a desativação... deixei... trinta e sete em construção... e as outras liciTADAS... então a nossa capaciDAde... de pegar o que você deiXOU do Maluf e do Pitta... que aí era uma hecatombe na educação verdaDEIra... porque não tinha esCOla... não tinha CREche... não tinha CEu... não TInha NAda... e MUlto MEnos caRREIra... então a história de vir dizer também que a sua carreira agora melhorou... de professor... também não é verdade...

L1: candidata... a senhora agora faz a pergunta... a última desse bloco... para o candidato Gilberto Kassab...

L3: bom... eu quero perguntar... ah:.... a pesquisa do IBOpe... ah:.... contratada pelo Nossa São Paulo... mostra que setenta e um por cento dos paulistanos... estão muito desagradados... e consideram o transporte da cidade RUim e PÉssimo... todo lugar que eu vou... falam do ônibus que não tem... da linha que não tem frequência... de tudo muito MUlto RUim... e precário na cidade de São Paulo... a minha pergunta é... porque o senhor deixou a cidade chegar nessa calamiDAde... que nós tivemos uma experiência... HOje... nessa sexta-feira... do jeito que esTÁ?...

L2: olha... eu queria dizer para o nosso eleitor... telespectador... que pela primeira vez... nós enxergamos a luz no fim do túnel... a cidade de São Paulo precisa investir em transporte público de qualidade... meTRÔ... corredor de Ônibus... GEStão da Cet... a::... então prefeita Marta deixou a Cet com cem milhões de dívidas... NUNca... um prefeito havia investido no metrô na cidade de São Paulo... nós estaremos investindo... até o final do ano... UM bilhão de reais... já transferimos para o governo do Estado... quinhentos e três milhões de reais... e os nossos corredores... demoram porque são corredores como devem ser feitos... eu sou um prefeito... que não tem a preocupação de colar nome... de colocar nome 
em placa... a minha preocupação é fazer o que é correto... o que é bom para a cidade... os nossos corredores... nos pontos de parada... não tem... tem área de ultrapassagem... não tem cruzamentos... estamos fazendo Expresso Tiradentes... que vai levar... as pessoas do CENtro até a Cidade Tiradentes... e em FAse final de projeto o corredor Celso Garcia... sempre vem o argumento da:.... candidata Marta... ah... mas isso não ficou pronto... é por isso que não tem corredor em São Paulo... é por isso que não tem... tanto metrô... porque a preocupação daqueles que me antecederam... e tá aqui... a ex-prefeita Marta... era colocar nome em placa... as obras demoram mesmo... nós temos que ter... espírito público... nós temos que fazer... não o que é bom para o mandato... nós temos que fazer... o que é bom PAra a cidade de São Paulo... e NA questão do trânsito... nós estamos fazendo eXAtaMENte aquilo que precisa ser feito... investir no transporte público de qualidade... e com certeza... com isso nós vamos melhorar o TRÂNsito na cidade de São Paulo...

L3: você que esTÁ em CAsa... você prestou atenção no discurso?... eu vou... estou fazendo... você... estou enxergando a luz... eu estou... agora... começando a ver $0 . .$. gente... governar... não é estar fazendo... usando o gerún::dio... fazen::do... enxergando luz... governar é fazer... e a realidade... é que você NÃO fez... você não fez os CINco corredores de ônibus que prometeu... o Expresso Tiradentes que você ficou de fazer TRINta e dois quilômetros... fez Olto quilômetros... e agora publicaram no jornal... que cancelou trinta e dois por cento do orçamento do que ia ser aplicado no Expresso Tiradentes... o meTRÔ... que você fala... podia ter posto este dinheiro muito antes... porque a cidade de São Paulo hoje tem condição... apresentou o cheque... mas ninguém nem sabe para onde foi... isso poderia ter sido antes... agora eu vou fazer... eu vou fazer o que eu consegui fazer... quando entrei na prefeitura e cheguei no bilhete único... eu vou fazer os corredores de ônibus necessários e por os recursos no metrô... o que você não foi capaz... de FAto... conCREto...

L1: candidata...

L2: a frustração da ex-prefeita... hoje candidata... é que eu estou fazendo... e ela não fez... eu esTOU colocando dinheiro no metrô... já quinhentos e três milhões... e vou colocar mais quatrocentos e noventa e sete... eu estou fazendo corredor como deve ser feito... nós recupeRAMOS a Cet... nós recupeRAMOS a cidade de São Paulo... e tenho sempre a humildade de apresentar os desafios que não foram superados... São Paulo é uma cidade muito grande... com problemas que tem a dimensão da cidade... mas nós esTAmos faZENdo muita coisa... ainda bem que a ex-prefeita reconhece... no campo do transporte... ampliamos o bilhete único... ela FEZ... duas horas... nós ampliamos para três horas... ainda no campo do transporte... o bilhete único... ampliamos para o metrô... para os trens... é um aVANço... não é?... renovação da frota... hoje metade da frota é renovada... seis mil ônibus... tem acessibilidade... isso é FAzer... é evidente... eu ainda sou prefeito... e eu estou fazendo... eu agradeço por a senhora reconhecer...

L1: muito bem... aSSIM... nós enceRRAmos... o priMEIro bloco do nosso debate com os candidatos a prefeito de São Paulo... ((aplausos))... a seguir... Marta Suplicy e Gilberto Kassab farão perguntas sobre TEmas determiNAdos por sorteio... até já...

((vinheta do intervalo comercial))

L1: estamos de volta com o deBAte entre os candiDAtos a prefeito de São Paulo... neste bloco... que vamos iniciar aGOra... os candidatos fazem perguntas sobre TEmas determiNADOS... que eu vou sorteAR... nesta pequena urna... que nós vemos aqui... vamos ver então... qual seRÁ... o primeiro TEma deste bloco... o TEma seRÁ... camelôS... camelôs... e como o candidato Gilberto Kassab 
aBRIU o bloco anterior... quem coMEça... a fazer a pergunta agora sobre este TEma... é a candidata Marta Suplicy... por favor... a senhora tem trinta segundos... L3: candidato... ah... houve um aumento muito grande da atividade no Brasil... econômica... nós temos muitas pessoas com carteira assiNADA... mas o comércio ambulante ainda é muito FORte... nós temos os ambuLANtes... que a grande maioria é gente honesta... trabalhadora... mas temos o comércio ileGAL... contrabandeAdo... eh... também... então eu queria saber... e que gera/... GEra esquema de corruPÇÃo isso... eu quero saber qual é a sua poLítica... pra:: acabar com isso... com esses esquema de corrupção?...

L2: em primeiro lugar... eu queria dizer que... nós somos a faVOR dos ambulantes... aqueles que trabalham com honestidade... aqueles que... SUam a camisa para levar... o recurso para sustentar as suas famílias... é evidente que... somos contra aqueles que trabalham com carga roubada... aqueles que trabalham com produtos pirata... o SHOpping popular é a saída... e o projeto... que está sendo aprovado no Congresso Nacional... que vai dar condições ao cidadão... de estar estabelecido legalmente... na sua própria casa... apresentando somente a NOta fiscal da COMpra da mercadoria... é a resposta... para que a gente possa na cidade de São Paulo... ter os ambulantes LEgalizados... aqueles que trabalham... como eu disse agora pouco... com honestidade... e eu queria aqui registrar... que:: combatemos como poucos... o crime na cidade de São Paulo... combatemos aqueles que faziam a poluição visuAL... os outdoors... combatemos os camelôs que vendiam Dvds piratas... nós inutilizamos mais de SEte milhões de Dvds piratas... isso é um número extraordinário... isso mostra um rigor na fiscalização... nós vamos... com os shoppings populares... e com a LEi... que será aprovada no Senado... já foi apo/... aprovada na Câmara... e que TEM o nosso apoio... tivemos lá em Brasília... estamos aTENto para a aprovação... o partido de nossa base aliada está votando a favor da lei... nós vamos REsolver o problema dos camelôs... e mostrar para a cidade de São Paulo que É possível sim... fiscalizar aqueles que trabalham com carga roubada... com produtos piratas... que aliás... diminuíram de maneira MUlto sensível na cidade de São Paulo... eu queria aqui recordar... o Largo da Concórdia... na Mooca... no Brás... que hoje está entregue de volta à cidade de São Paulo... o Largo TREze... em Santo Amaro... para exemplificar algumas de nossas ações... que tiraram o camelô que trabalhava com produto ROUbado...

L3: eu queria dizer que quando eu entrei na cidade de São Paulo... ela estava contamiNAda... pelo Vírus da corrupção da gestão PITTA... da qual o senhor foi secretário de planejamento... nós tínhamos a MÁfia dos fisCAIS... recémexTINta... e nós criamos a ouvidoria para receber as reCLA-MAÇÕES da população... e também a via RÁpida... para tirar qualquer funcionário coRRUPto... agora... Kassab... eu gostaria de que você me respondesse... e ao telespectador... nós tivemos... eh... temos na PRIsão... há TRÊS meses... Marcelo... Marcelo Eivasia... que é auxiliar seu... é depuTAdo... candiDAto a deputado... pelo PflDEM... e era responsável pelos fiscais... exatamente no Largo da Concórdia... e... e também foi responsável pelos esCÂNdalos no Largo da Concórdia... no BRÁS... toda essa região... e na MOOCA... esse... esse cidadão está PREso... há TRÊs MEses... com ajuda da Rede GLObo... e da Polícia FedeRAL... a MÁfia dos fiscais... volTANdo em São PAUlo?...

L2: ele está preso Marta... porque é um criminoso... e qualquer que seja o seu partido... nós somos rigoRosos com ele... e ajudamos a colocá-lo na cadeia... mas eu nunca vi manifestação sua... em relação... aos seus companheiros da executiva do Pt... você era VIce-presidente do Pt... o presidente... Genoino... o secretário... Silvinho Pereira... o tesoureiro Delúbio... o ProcuRAdor-Geral da 
República... chamou de uma QUAdrilha... e eu nunca vi você CRlticar os seus companheiros... que FAzem campanha com voCÊ... e dizer que você se afastou... eu me afastei do Pitta... eu coloquei esse cidadão na cadeia... que ele é um criminoso... mas eu queria ouvir de você... o que você pensa... desse time... que o ProcuraDOR-Geral da República chamou de QUAdrilha?...

L3: você não colocou esse...

L1:

[

ah...

L3:

cidadão na cadeia...

L1:

[

L3: $\quad$ acabou?...

L1: nesse momento... candiDAto Kassab faz a perGUNta...

L3:

ah... desculpa...

L1:

responder... a tréplica...

ele acaba de

L3: desculpe...

L1: o senhor faz a pergunta... o senhor tem trinta segundos...

L2: não vai sort

L1: $\quad$ para a pergunta... vamos fazer o sorteio... vamos fazer o sorteio... 0 tema sorteado é... habi-taÇÃo...

L1: habitação... vamos voltar ao tema habitação porque é um tema MUlto importante para a cidade de São Paulo... NóS encontramos no início da nossa gestão... aproximadamente... TRÊS milhões de pessoas que moravam em condições inadequadas... eu queria... perguntar... a candidata Marta... QUAI é a sua proposta... para resolver... Efetivamente... o problema de FALta de habitação na cidade de São Paulo?...

L3: olha... eu agradeço que tenha caído habitação novamente... porque o candidato KaSSAb desQUALIFICOU... aquilo que eu acabei de LEr... "deixar os móveis desmontados com antecedência... amarrar as portas dos armários e gaVEta... colocar coisa miúda em CAixa... não deixar crianças no caminho das muDANÇAS... deixar o almoço ou o lanche PRONto... avisar no serviço que vai falTAR..." isso não é uma pegaDInha... nem um documentinho qualquer... esse é o docuMENto da prefeiTURA do muniCíPIO de São PAUlo... secretaria da habitação e desenvolvimento... Sead... Superintendência da Habitação PopuLAR... Abi/... Abi centro... foi recebido pela dona Jucilene SILVA... no Jardim Edith... eu já tinha mencionado ANtes... que o Jardim Edith é aQUI... do LAdo da Rede Globo... do lado da Ponte Estaiada... ah... o senhor tem QUInhentos milhões... quiNHENtos milhões de recurso no BANco... que só pode ser usado AQUI... porque é uma operação urBAna... e não usou... agora... tentou expuISAR... o pessoal do Jardim EdiTh... de lá... da favel/... é uma faVEla... eu passei... outro dia de novo lá na frente... uma favela que o senhor usou... caCHOrro... GÁs lacrimoGÊnio... e mandou esta CARta... para essa senhora... estou lendo a CARta dessa senhora... e que é uma senhora... como as miLHAres de pessoas que recebem essa CARta aqui em São Paulo... que CHOram... que ficam desespeRAdos... que não tem o que fazer... porque não tem emPREgo... não tem coMlda... e o senhor manda essa CARta... e no dia 
seguinte... GÁs lacrimoGÊnio e caCHOrro... entende?... essa é a sua poLítica há-bi-ta-cio-NAL... e ISSO é o que me deixa in/... indigNAda... porque a política deCENte nessa ciDAde... de diÁlogo... de urbanização de faVEla... de Bairro LeGAL... de habitaÇÃO no CENtro da ciDAde... de resPElto às pessoas que tem menos... e estão lá porque não TEM outro lugar para IR... foi COMpletaMENte abandoNAda... o que o senhor consegue faZER... é com o dinheiro do PAc... na ParaiSÓpolis... na Helio/... HeliÓpolis... e os GRANdes projetos de haBltação na cidade de São Paulo... esTÃO paRAdos...

L2: Marta... nós em dois mil e oito... estamos investindo oitocentos milhões em habitação... você investiu duZENtos milhões... ao longo do seu governo... você teve ações em dezeNOve favelas... nós estamos tendo ação... porque sou prefeito... estou fazendo... conforme você reconheceu... em noVENta e nove favelas::... você abandonou os mutirões... começados pelo nosso queRIdo e saudoso Mário Covas... nós estamos conclulNdo todos... enfim Marta... é importante aqui discutir políticas públicas... e não um documento... que a gente não sabe da onde veio... e que o eleitor que está nos assistindo... o telespectador... ele quer... efetivamente saber... QUAl é a sua proposta para a habitação... como é que você vai resolver... eu perguntei a você... como é que seRÁ resolvido o problema da habitação na cidade de São Paulo... PARAisópolis está deixando de ser uma favela para ser um verdadeiro BAlrro urbanizado... estamos colocando ilumiNAÇÃO... pavimenTAÇÃO... e Heliópolis... da mesma maneira... e quanto ao Governo Federal... ele deu VINte por cento... eu sou muito grato aos vinte por cento... SEMpre reconheço isso ao presidente Lula... VINte... oitenta por cento foi eu...

[

L1:

seu tempo acabou...

L2: $\quad$ e o Serra...

L1: candidato... candidata...

L3: o documento está aqui... acabando o debate eu vou entregar ao Chico Pinheiro e à imprensa... agora a sua urbanização de favela... não é só como no Jardim Edith... favela aqui do lado... é também na que eu visiTEl... e lá... Kassab... eu choREi... porque eu VI... uma das coisas mais perVERsas... que eu jamais tinha visto... uma favela chamada Cambuçu... eu deixei prontinho para você urbanizar... você urbanizou... só que dividiu a favela no meio... fez um MUro... e do outro lado... deixou o resto da faVEla... então as CRIANças vinham para MIM e falavam assim... a senhora vai conseGUlr... me por do lado que tem casa?... as crianças morando... olha... era um... era uma colsa... de triste... de ver aquilo... porque eu me comovo... eu cuido das pessoas... eu PENso nas pessoas... não com números... como você pensa... eu PENso nas pessoas... como GENte... eu estou lá para cuiDAR das pessoas... quando eu fui prefeita... e agora... conseguir ser prefeita de novo... é eXAtaMENte... para cuidar com deCÊNcia... das pessoas que mais precisam nessa cidade...

L1: candidata Marta Suplicy faz agora a pergunta ao candidato Geraldo... Gilberto Kassab... e o tema é... CREche... creche...

L3: Kassab... você:..... eh... continuou a maldade do PITTA... de tirar as crianças da creche com três anos... só que tira a criança de dez horas de uma CREche para ir para uma EMEi... você não abriu tantas vagas... aliás... abriu muito poucas vagas em Emei... o déficit é quarenta e seis mil VAgas em Emei... então a mãe tira... eh... tira... aquela criança sai da creche... num tem Emei para ir... se 
consegue uma Emei eh:.... é por muito menos tempo... você tem hoje CENto e dez mil crianças fora da creche... quarenta e seis fora de Emei... e como planeja acabar com esse déficit?...

L2: é importante que o telespectador saiba... que VAga em creche... significa VAga para crianças de ZEro a três anos... e VAgas para essas crianças... nós fizemos ao longo da nossa gestão... quarenta e seis... quaRENta e cinco mil vagas... a ex-prefeita e hoje candidata Marta fez ONze mil vagas... o que ela fala... que fez mais vagas... mas ela inclui crianças acima de três anos... não... CREche é de ZEro a três anos... portanto... nós vamos... na próxima gestão... ZErar as vagas... a falta de vagas em creche na cidade de São Paulo... e para um governo... como o nosso... que nesses quatro anos fez o Cidade Limpa... fez cento e quinze Amas... acabou com a sala de lata... acabou com as escolas de lata... enfim... um governo que... para tudo aquilo que se propôs... FEZ... é evidente que... tendo a eliminação da... falta de vagas de creche como nossa prioridade absoluta... nós vamos sim... conseguir atingir esse objetivo... portanto... o tema creche é um tema delicado... é um tema diFícil na cidade de São Paulo... em termos de vagas de creches... quase o tanto que foi feito desde a FUNdação de São Paulo até o início da nossa gestão... e agora... nós vamos resolver o problema sim... porque É a nossa prioridade... e nós temos CREdibilidade... para afirmar... e as pessoas confiarem...

L3: olha... depois desses números a tua credibilidade... se não estava boa com número... foi para o brejo... porque esses números NÃO procedem... eu criei... mais ou menos o mesmo número de vagas de creche... que você criou... só que eu criei... MUltas vagas em EMEis... que você NÃO criou... e deixou quaRENta mil crianças fora de Emei... agora... não é um assunto delicado... creche... creche é um assunto conCREto para a mulher... CREche é um aSSUNto... que a mulher preClsa TEr CREche... para poder ir trabaLHAr... e trazer o orçaMENto... para a sua faMília... creche... Kassab... é necessário para criANça... para a criança poder aprenDEr... para ela ter uma nutrição adeQUAda... para a criança poder... SE desenvolver... e isso... você NÃO entende... não pôs como prioriDAde... agora eu... se eleita preFElta... vou dar prioridade SIM... porque sei da importância para a criANça... sei da importância para a MÃE... vamos construir creches... onde não tem NAda... você precisa construir... vamos fazer os convênios e auMENtar os convênio também... e também fazer o Pró-uni da Criança... ou o Pró-Criança... onde não tem VAga... ou escola... você compra vaga na escola particular...

L1:

está bom

candidata... acabou o seu tempo... candidata MARta...

L2: quem ouve... a candidata falar... até imagina que ela não foi prefeita... pois bem... em CREche::... vamos voltar ao ponto básico... nós fizemos quarenta e cinco mil vagas... é um tema delicado sim... um tema importante... que foi relegado a um último plano em administrações anteriores... NÓs... demos uma prioridade... agora será prioridade total... e comparativamente nós criamos quarenta e cinco mil vagas... a Marta criou ONze mil vagas... e na próxima gestão... nós vamos zerar... porque nós falamos que... o problema da falta de vagas em creches... porque nós falamos que íamos acabar com as salas de lata... acabamos... que íamos acabar com as escolas de lata... acabamos... que íamos reFORmar todas as escolas... reformamos... que nós íamos recupeRAR o poder aquisitivo do servidor... PRINcipalmente do servidoR da educação e da saúde... nós estamos recuperando... que nós íamos contratar médicos... contratamos mais de três mil... portanto nós VAmos resolver sim o problema de creche... 
L1: muito bem... vamos sortear mais um tema... PAra a última pergunta deste bloco... que será feita pelo candidato Gilberto Kassab... o tema é... seguRANça... candidato... o senhor tem trinta segundos para a sua pergunta...

L2: segurança é uma questão... fundamental na cidade de São Paulo... apesar de ser... de responsabilidade do Governo Federal... do Governo do Estado... nós não nos temos furtado... a ações importantes... para cooperar com o Governo do Estado... com o Governo Federal... eu queria... aqui perguntar... à candidata Marta... eh... qual a sua proposta para a iluminação pública... e por QUE... no final de sua gestão... nós tínhamos a cidade TÃO atraSAda na questão da iluminação pública?...

L3: começando com a sua perGUNta... porque você terminou o Reluz... não usando cento e oitenta e cinco miLHÕes desse projeto que iluminava a cidade... esse projeto que o Senado demoROu para aproVAR... que eu consegui que aprovasse... troquei... milhões de PONtos de luz na ciDAde... troquei as LÂMpadas da cidade de mercúrio para Sódio... iluminei os cruzamentos dessa cidade... agora segurança é muito mais do que só LUz... luz é importantíssimo... mas... e a secretaria de segurança que você extinguiu?... e a Guarda Municipal que você abandoNOU... totalmente... não reeqUIPOU... o efetivo hoje chega a estar menor que o na minha Época... você aGOra está chamando para conCURso... e a RONda EscoLAR?... que os professores reclamam TANto que agora não tem mais?... o NARcoTRÁfico... Kassab... voltou para a porta da escola... as mães ficam desespeRAdas... tem agora uma segurança terceirlZADA... que não é parCEIra da comuniDAde... as quarenta e nove BAses comuniTÁrias que eu fiz nessa ciDAde... você também abandoNOU... essas BAses que são tão importantes... porque... a GUARda que está aLI... ele olha e fala... aquele ali é o filho do açoGUEIRO... aquele ali eu conheço... é o amigo do vizinho... esse aí eu não conheço... vou prestar atenção... tudo desatiVADO na cidade... e a luz também é outro ponto importantíssimo... e esse ponto você tem responsabiliDADE... porque o projeto ReLUZ... você não utilizou... CENto e oiTENta e CINco MIlhões... eu estou falando... que é o empréstimo que vem do governo LUla... para a questão da luz... então eu acredito que na segurança... foi MUlto RUim... e a secretaria de segurança... eu VOu... de novo... colocar em PRÁtica... vou retomar a RONda EscoLAR... vou aumenTAR o efeTIvo da GUARda municiPAL... vou REEquipar... porque as motinhos que eles andavam nos PARques... davam seguRANça às faMílias... tudo isso acabou... porque você NÃO fez NEm a manuTENção... e também... vou retomar o projeto Reluz com TUdo... porque é um projeto bom... ajuda muito a fazer...

L1:

[

L3: candidata...

iluminação da cidade...

L1: $\quad$ ah... seu tempo acabou...

L2: o telespectador sabe... que em TOdos os momentos que eu posso... até porque é justo... eu sou reconhecido ao presidente LUla e ao governador Serra... o que a assessoria... não me leve a mal... candidata... da candidata não informou a ela... que no caso do Reluz... o Governo Federal NÃO liberou a verba... portanto eu estou muito tranquilo...

L3:

porque né?

você sabe 
[

L2:

tenha a sua vez... candidata... portanto estou muito tranquilo em relação a essa questão... eu queria aqui... abordar a questão das... câmeras de segurança... queria saber se a EX-prefeita e candidata hoje... pensa em AMpliar... o número de câmeras na cidade de São Paulo?... e QUAis são as regiões que serão afetadas por essa ampliação?... e tamBÉM... pel/... observar a ela que nós doBRAmos o número de viaturas em relação à situação enconTRAda... e também aumentamos o efetivo de uma maneira muito significativa... o número de guardas civis metropolitanos...

L3: esses dados que o Kassab coloca... não são verdadeiros... não existe essa ampliação de fato... agora que estão chamando concurso da guarda... e a ROnda Escolar NÃO existe... o programa Reluz... vocês ficaram discutindo... a venda da conta da... luz do Itaú... acabaram não podendo... não podendo ter aCEsso ao Reluz por Isso perderam cento e oitenta e cinco milhões... ninguém está mal informado aqui... e as câmeras de segurança... acho importante coloCAr... mas nós vamos fazer observaTórios de segurança... nas subprefeituras... por que?... com a secretaria de segurança... São Paulo... que é a QUARta meTRÓpole do MUNdo... que hoje não TEM secretaria de segurança porque Kassab extinguiu... passará a ter de NOvo a secretaria de segurança... e vai ter observaTÓrios de segurança em CAda subprefeiTUra... e aí pode coleTAr as informações da violência naquela regiÃO... então vai saber se teve esTUpro... se teve pancadaria em algum luGAR... ou que tipo de violência está ocoRRENdo... que a iluminação está ruim naquele lugar... e eu acho que vai adiantar muito para a população...

L1: muito bem... terminamos MAis este bloco... vamos fazer um pequeno intervalo... ((aplausos))... já já voltamos com mais um bloco de perguntas de tema livre... entre os candidatos a prefeito de São Paulo... aguarde...

((vinheta de intervalo comercial))

L1: estamos de volta com o último debate para prefeito de São Paulo nestas eleições... dois mil e oito... este é o seGUNdo bloco de perguntas de tema livre... ou seja... cada candidato faz a pergunta que quiser ao outro... QUEM começou o bloco anterior... foi a candidata Marta Suplicy... portanto quem abre este bloco é o candidato Gilberto Kassab... por favor...

L2: SEMpre que... a candidata Marta é cobrada... em relação a algumas ações suas... quando prefeita de São Paulo... ela vem com a explicação que não tinha recursos... que não tinha dinheiro... que encontrou uma cidade falida... mas ela fez... dois túneis na região dos Jardins... famosos túneis... que custaram trezentos milhões de reais... ela pegou o Fura-Fila e gastou trezentos e quarenta milhões de reais... para deixar a obra parada... gastou cem milhões de reais com assessores de confiança... Marta...

L1:

[

L2:

não priorizou os recursos adequadamente?... seu tempo acabou... candidato... por que você L3: olha... Kassab... eu acho que a gente tem sempre que ver... a cidade que eu peguei... e os recursos que eu não TInha... você me deixou uma cidade... junto com o Pitta... faLIda... com uma dívida giganTESca... e a cidade acaBAda... quantas vezes eu vou ter que repetir Isso... que é muito diferente da cidade que você recebeu... organiZAda... com Plano DireTOR... trinta e uma 
subprefeiTUras... coisas aconteCENDO... e transporte em ORdem... agora... é muito importante falar desses túneis... porque você repete... repete... as pessoas vão acabar acreditando... esses túneis são fruto... de uma operação urBANA... é recurso PRIvado... e esse recurso NÃO pode ser usado a não ser naquele local... e NÃO é recurso do orçaMENto... então quando você diz... podia ter construído hospiTAL... podia ter construído esCOLA... não podia não... ele é ali da região da Faria LIma... ou punha no metrô... e ali não TInha como colocar no largo da Batata porque não tinha projeto PRONnto... (esse recurso) só podia colocar ali... porque era uma operação urBANA... ou fazia os túneis... e eu não sou como você... de deixar o dinheiro no BANco... eu recebi os recursos... da VENda desses... eh... dessa operação urbana... em outubro... em outubro eu comecei a obra... e entreguei... antes da Obra... eh... eh... antes da eleição... então... não... foi depois da eleição que eu entreguei até... eu consegui terminar antes de terminar o meu manDAto... então esse negócio do túnel eu espero que esteja esclarecido uma vez por outra... e não adianta ficar dizendo que o túnel é assim ou assado porque está LÁ... funciona BEM... serve à zona SUL... as pessoas gostam... as que estão no MorumBI... os que moram LONge... o meu filho que estava até aí falou... mãe... diga que eu moro ALI... e que eu passava TRÊS minutos no sinal... e agora é UM minuto... então beneficiou uma população muito grande... mas... o que eu quero dizer para voCÊ... é que eu construí os corredores na cidade... e você não construiu nenhum... você prometeu CINco... e não construiu nenhum... e isso que faz difeRENÇA nessa cidade de São PAUlo para o trânsito... para as pessoas que precisam de conDUÇÃO...

L1: candidata... o seu tempo está encerrado...

L2: a pergunta que eu fiz é por que ela investiu esses recursos NEssas obras e não investiu em outras obras... na região de Pinheiros... poderia sim investir no metrô... o Fura-Fila... trezentos e quarenta milhões... pra ficar parado... CEM milhões de reais... para contratar funcionários de confiança... no início do meu governo... nós demiTImos vinte por cento... e economizamos em renegociação de contratos... nós economizamos... quase um Bllhão de reais ao longo da gestão nessa renegociação... na demissão desses assessores... porque administrar é PRlorizar... e a pergunta que eu fiz é em relação a Esses recursos... eu teria investido na construção de Amas... na reforma de escolas... eu teria investido na melhoria da qualidade do ensino... na melhoria da qualidade da saúde... em programas de recapeamento... porque... como eu disse agora pouco... precisa saber... pri-o-ri-zar...

L3: eu acredito.... Kassab... que a prioridade/ nessa ciDAde são os correDOres... porque a maior parte dessa cidade... anda de Ônibus... a maior parte dessa ciDADE... se você tivesse construído UNzinho dos corredores que você prometeu... aquele lá da Celso Garcia... você está lá há QUAtro anos... QUAtro Anos Kassab... não são dois... são QUAtro... vocês não administraram juntos?... são QUAtro anos... NÃO fizeram UMA licitação de correDOR... né?... não conseguiram nem ter proJEto... para conseguir licitar o da Celso GARCIA que já está na tua propaGANDA... fazendo... acontecendo... entregando... não conseguiu... então na minha gesTÃO... a prioridade foi... corredor de ônibus... isso é a Única responsabilidade da prefeitura... porque... no transporte de superfície... é onde ela SAbe que pode ter mais resulTAdo... e ninguém mais pode fazer... a não ser a prefeitura... a prefeitura é a Única que pode investir no corredor... metrô?... eu não tinha reCURSOS... agora que tem... porei...

L1: candidata Marta Suplicy faz agora a sua pergunta...

L3: candidato... você disse que o meu governo era bom de licitação... eu acho que era muito bom de licitação mesmo... licitamos a Radial Leste... licitamos os Ceus 
que você está fazendo... licitamos os dois hospiTAis... licitamos a Jacupêssego... eu licitei quarenta e nove Ubss... mas QUAtro Anos depois de começar o seu governo... eu não vejo nenhuma obra importante sendo liciTADA... e mesmo... vou repetir... a Celso Garcia... você não conseguiu até hoje licitar... por que é que você tem tanta dificuldade?...

L1:

candidata o seu

tempo...

L2: olha... eu lamento o desPREZO... que a candidata tem... por aqueles que não tem moradia própria... ela dizer... que não é uma licitação importante... uma licitação acima de UM bilhão de reais... na área de habitação... que vai reurbanizar... deZEnas de favelas... cenTEnas de milhares de pessoas vão... com esses recursos... ter acesso a uma casa própria com digniDADE... eu quero dizer a vocês que... é a maior licitação da história na área de habitação... e que vai resolver o problema de moradia de miLHAres de pessoas... o desPREzo dela por uma licitação desse porte... eu preferi sim... licitar obras na habitação do que fazer esses dois túneis... ao invés de fazer... trezentos e cinq/... trezentos e quarenta milhões de investimentos numa obra do Fura-Fila para ficar parada... ao invés de contratar funcionários de confiança... que geralmente eram militantes do seu partido... para cargos com salários polpudos... eu investi na habitação... é a maiOR licitação e o maiOR programa de urbanização de favelas da hisTÓria da cidade de São Paulo... eu investi em reformas de escolas... você que está nos assistindo... sabe que nós reformamos TOdas as escolas da rede municipal de ensino... você sabe que... nós estamos construindo... e ela reconhece... estamos... eu sou prefeito... algumas já construídas... todas já concluída até o final do ano... duZENtas e dezessete novas escolas... portanto... eu tenho MUlto orgulho dos recursos que empreguei em obras... são investimentos que vieram pra ficar... e as minhas licitações... eram foram direcionadas para BONs projetos para a cidade de São Paulo... e principalmente... para melhoRAR a qualidade de vida das pessoas...

L3: Kassab... quem tem desprezo aqui é você pelas pessoas... não só do... da favela do Jardim Edith... mas da favela do CamBUÇU... e das outras que eu tenho visitado... e capacidade de fazer licitação... que é TÃo importante... tem que PENsar a obra... depois tem que projetar e fazer a licitaÇÃO... eu vou ler para você que está em casa... o que que aconteceu... nas licitações que foram feitas... "novos radares... suspensão por decisão judicial... transporte escolar... suspenso por des/... decisão judicial... Expresso Tiradentes... e continuação da Roberto Marinho... suspensa pelo Tribunal de Contas por suspeita de IRREgularidades..." por fim... "contrato para duZENtas e cinquenta creches... suspensa pelo Tribunal de Contas..." nem as creches você conseguiu licitar na sua gestão... Kassab... então a incapacidade... de PENsar... de fazer o projeto obje/... de fazer o projeto executivo... depois de li- Cl-tar... e poder faZER... eu acho que você conseguiu executar MUlto POUco... com DEZ bBIlhões a MAis... por Ano... que você teve... QUAtro Anos... você não está dois... está há QUAtro...

L1: candidata...

L2: em relação aos radares... a ex-prefeita esquece de falar que fomos MUlto duros numa licitação... a licitação foi concluída... estamos pagando TRÊs vezes menos do que pagava o seu governo... e agora São Paulo tem uma empresa séria a frente da administração dos radares da cidade de São Paulo... em relação ao muro... que você fala... pela segunda vez dessa favela... eu queria dizer que a exprefeita... eu lamento mas... falo isso respeitosamente... ela precisa ser melhor orientada pelos seus assessores... esse muro é uma obrigatorieDADE... de 
qualquer cidadão que queira a segurança de suas pessoas... porque tem uma LInha de transmissão ao lado da favela... e esse muro é para que se isole as pessoas... porque elas podem... evidentemente... estar sem segurança se não tivesse esse muro... que elas não podem CIRcular... sob uma linha de transmissão...

L1: muito bem...

L3:

[

L1: eu não estou... posso falar?...

[

L3: $\quad$ ou acabou?...

L1: nesse momento... o candidato Kassab faz a sua pergunta... estamos nesse bloco com tema livre... o candidato dirige a pergunta que quiser... a candidata Marta Suplicy...

L2: eu queria perguntar à candidata Marta... eh... em relação ao programa de hospiTAL domiciliar... nós fizemos muita coisa na saúde... CENto e quinze Amas... dois novos hospiTAis... a informatização da rede... o Programa Mãe PaulisTAna... o Remédio em CAsa... e agora... estamos com o programa de implantação de LEltos hospitalares nas residências... eu queria saber o que pensa a prefeita em relação a esse programa... e se ela vai continuá-lo?...

L3: olha... nós começamos na nossa gestão... o atendimento domiciliar... mas o que eu vou falar... é sobre o que eu vou fazer na saúde... né?... que eu pretendo fazer muito e dar um salto eNORme... que é o salto que... durante esses QUAtro anos... com DEZ bilhões a MAis... todo ano... você não deu... que é fazer uma centra/... os CENtros que as pessoas possam TER... os médicos de especialidade... ou os exames de imagem... eu ando na rua... Kassab... a única coisa que eu escuto é as pessoas vir dizer... olha... uma tomografia... dez meses... uma ressonância magnética... UM ano... e as pessoas estão nessa condição... é reclamação pra TOdo lado... é uma das áreas de pior avaliação da tua gestão... é a Área da saÚde... apesar dos dados que você fala das Amas... as Amas foram uma boa idéia... elas acoLHEM... mas elas não resolVEM... temos as Ubss... que também são porta de enTRAda... nós temos o programa Saúde da Família... que eu fiz oitoCENtas equipes... você fez duZENtas... então nós temos TRÊs portas de entrada... AMA... UBS... e o programa Saúde da FaMíLIA... nós precisamos colocar mais MÉdicos LÁ... e dePOIS nós temos que coloCAR informatiZAÇÃO... no sistema todo de saÚDE... PAra que... na construção das poliCLíNICAS... que faremos UMA em CAda subprefeiTUra... a pessoa quando for na Ama e for atenDIda... e o medido disser... mas você precisa de um cardioloGISta... aí ELE lá... com tudo informatiZADO... vai poDER MARcar na HOra pra pesSSOa numa poliCLÍNICA da região DEla... da subprefeitura dela... ESSe SALto de especialiDAde e de imaGEM... que era o que eu tinha posto quando eu disputei a eleição... está no mesmo PÉ... não foi feito nada... as pessoas tem o prontoatendimento da Ama... mas ela não consegue fazer um exame na cidade... esse salto é o que eu vou dar... e eu vou recuperar os hospiTAIS... construir mais três... Jaçanã... Trem/... Tremembé Parelheiros e BrasiLÂNdia... e recupeRAR... por exemplo... outro dia eu fui no hospital do Jabaquara... Deus me livre... tinha MAca na rua... o pessoal choRANDO... era realmente... eu pensei... onde é que eu estava... não parecia que eu estava na minha cidade de São Paulo...

L2: nós temos já seSSENta pacientes com leito em casa... é o equivalente a uma hospital... e VAmos continuar avançando... na saÚde... nós investimos muito e 
melhoramos deMAis... a qualidade do atendimento público de saúde... está o ideal?... é evidente que não... mas vamos continuar melhorando... vamos fazer mais Amas... a Policlínica que... a candidata aqui... apresenta... na verdade... são as Amas com atendimento... com as consultas de especialistas... já temos CINco na cidade de São Paulo... até o final do ano serão QUINze... e na próxima gestão... já no ano que vem... MAis quinze... o programa Remédio em Casa será ampliado... a MÃE Paulistana... continuará existindo... dando um enxoval MARAvilhoso para as mães que participam do programa... a campanha da candidata disse que o enxoval... não dava nem pra limpar pia... mas é um enxoval maravilhoso... enfim... VAmos continuar priorizando a saúde... este ano são três bilhões e duzentos miLHÕES de reais... o DObro do que ela investiu...

L3: candidato... esse programa que você fala... Mãe Paulistana... foi iniciado na minha gestão... como o Remédio em Casa também foi... o Mãe Paulistana atingiu cem mil pessoas... que era começo de programa... o Remédio em Casa começou também na NOssa gestão... formulado pela nossa equipe... começou no BAlrro da LApa o projeto piloto... que agora está em expansão... mas eu vou fazer uma pergunta para você que está em casa... você conhece alguém que recebe o Remédio em Casa?... porque o número é desse tamainho... então a propaGANda que você vê na televiSÃO... não é o que é na realiDAde... as pessoas chegam nos hospiTAis... e não conseguem atenDIMENTO... as pessoas não conseguem fazer um eXAme de especialiDAde... nas policlínicas que eu vou fazer uma em cada subprefeitura... eu vou colocar VINte e três especialiDAdes MÉdicas... e vou colocar os exames de iMAgem... na poliCLíNICA... a pessoa faz a conSULTA... ela vai no mesmo local... poder fazer a sua ressonância magnética... fazer a tomografia... ou a mamografia... na mesma região que ela mora... é difícil?... é... mas a gente consegue...

L1: muito bem... agora a candidata Marta Suplicy faz a sua pergunta de tema livre para Gilberto Kassab... a senhora tem trinta segundos...

L3: Kassab... eu não gostaria de retomar o tema do pedágio urbano... mas vou retomar... a população precisa ser informada... que o seu líder... do seu partido... Apolinário... de novo reiterou que é a favor do pedágio urbano... e propôs já com o seu projeto... QUAtro reais... a minha pergunta é... quando vai começar o peDÁGIO?... é logo depois da ELElção?... como é que estão os preparativos pra isso?...

L2: SÃO PAUlo sabe... porque eu tenho credibilidade pra isso... que enquanto eu for prefeito de São Paulo... não haverá pedágio urbano... e a ex-prefeita... e hoje candidata... ela precisa aqui... sempre... ser correta com o telespectador... quando ela diz que um vereador do meu partido apresentou o projeto... é um direito dele... eu posso afirmar... que ele apresentando ou não... não haverá pedágio urbano na cidade de São Paulo... eu não sou um ditador... cada parlamentar tem o direito de apresentar o projeto que quer... porém ela também omite... que o seu principal colaborador... seu coordenador de campanha... deputado federal Gilmar Tatto... seu secretário de transportes... ele defende o pedágio urbano... e ela aqui... esquece de omitir isso... porque cada um tem a idéia que quer... não é?... se o vereador Apolinário apresentou o projeto... é um direito dele... eu não vou proibilo... nós estamos numa democracia... agora... enquanto eu for prefeito de São Paulo... NÃO haveRÁ peDÁgio urbano na cidade de São Paulo... ao contrário... vamos continuar... com recursos do orçamento... que nós economiZAMOS... na renegociação de contratos... que nós... com muita austeridade... estamos sabendo investir... transferi dinheiro para o metrô... ela fica... sempre... preocupada quando eu falo do metrô... porque nenhum prefeito investiu antes... já são quinhentos e três milhões de reais... até o final do ano... um bilhão de reais... vamos continuar 
fazendo corredor de ônibus como devem ser feitos... vamos continuar melhorando os beneFícios para o trabalhador... já aumentamos o bilhete único... no seu governo eram duas horas... no meu passou para três horas... aos domingos é o Amigão... oito horas de duração... nós vamos continuar recapeando a cidade... pavimentando a cidade... fazendo mais Amas... mais hospitais... porque Isso é usar o recurso público com austeridade... com correção... e eu... não vou aqui... deixar... de registrar... que qualquer que seja o vereador... eu sou CONtra pedágio urbano na cidade de São Paulo...

L3:<smiles>C[13CH2]OC</smiles>

L2: ela omitiu essa questão do seu principal colaborador... GILMAR TAtto...

[

L1: $\quad$ seu tempo acabou... candidato...

L2: olha... eu não mandei nunca... para a Câmara... projeto de pedágio urbano... e nenhum vereador MEu... mandou projeto de vereador... de... de... projeto urbano... e muito menos um Líder meu... mandaria um projeto de pedágio urbano sem falar comigo... então isso não ocorreu na minha gestão... independentemente do que poderia pensar qualquer secretário... agora é importante... você que está escutando em casa... que o/... o prefeito... mandou um projeto de pedágio urbano... diz que era erro... mandou retirar... depois foi OUtro projeto... aí... não era para todo mundo... era só para quem passasse na marginal... depois 0 Apolinário... que é o líder do Dem... que é o partido DEle... mandou um projeto... e LEU... na CâMARA... aGAra... está na televisão... QUAtro reais para sair de CAsa... ele leu... e disse que tinha conversado com o prefeito... que era um bom projeto... e agora... o vereador POLICI... também mandou um projeto semelHANte... e ele não é líder do Dem... ele é Líder do SEU goVERno... então... dá pra acreditar?...

L1:

[

candidata...

L2: Marta... ESSE é o problema da sua campanha... NEM você acredita naquilo que você fala... e muito menos o telespectador... ELE SAbe que eu sou contra o pedágio urbano... ELE SAbe o que eu fiz no transPORTE... que eu pus o dinheiro no metrô... que você não colocou... ELE SAbe que é uma boa administração a nossa... que está sendo bem avaliada... ELE está saBENdo aGAra que eu tenho um vereador do meu partido que apresentou projeto que eu sou contra... que você determina... que você MANda nos seus vereadores... eu não mando em ninguém... eu dialogo... ELE SAbe aGOra que o seu secretário de transporte é a favor do pedágio urbano... portanto... essa é a diferença da sua campanha da minha... precisa convencer o eleitor... precisa falar a verdade para o eleitor... é isso que eu tenho feito DESde o primeiro dia da campanha... elevado... num elevado nível... apresentado propostas... falando a verdade... respeiTANdo aqueles que estão comigo na vida pública... inclusive os vereadores... e eu não SOU da turma do Pitta... o eleitor sabe que eu não sou... agora... você não me disse... você É ou contra a quadrilha que o procurador-geral chamou?...

L1: nós encerramos mais esse bloco... o bloco de tema livre... e no próximo bloco... ((aplausos))... os candidatos farão as perguntas em cima de temas determinados pelo sorteio... é daqui há DOis minutos... depois do intervalo... até já...

((vinheta de intervalo comercial)) 
L1: estamos de volta com o último bloco de perguntas... entre os candiDAtos à prefeitura de São Paulo... mais um bloco de tema determiNAdo... seguindo a alternÂNCIA... começamos agora... com a candidata MARta Suplicy... que vai abrir a pergunta desse bloco... e o sorteio para o tema é... SAÚde... candidata... a senhora pode dirigir a sua pergunta ao candidato Gilberto Kassab...

L3: Kassab... o lbope... contratado pelo instituto Nossa... São Paulo... fez uma pesquisa que mostrou... que seSSENta e nove por cento das pessoas... consideram a saúde como RUim e PÉssima na cidade de São Paulo... e seTENta por cento estão MUlto insatisfeitas com a saúde... os seus dados são sempre sobre as Amas e dessa satisfação... eu gostaria de fal/... que você respondesse... sobre esta pesquisa MAis ampla... que é com TOdos os usuários as saúde... como é que você explica essa realidade?...

L2: é fácil Marta... até porque o MESmo lbope... fez uma entrevista depois... com os usuÁrios dos NOvos serviços... e os usuÁrios dos NOvos serviços... mostraram que estão MUlto contentes com os novos serviços... as cento e quinze Amas... os dois novos hospitais... a informatização da distribuição de remédios... a central de medicamentos... enfim... hoje... existe... de parte da população... tanto é que a minha avaliação é muito... a minha gestão é muito bem avaliada pela população... sessenta por cento da população entende que ela é ótima ou boa... diferentemente da tua gestão... porque você às vezes aqui... se apresentando... parece que você foi prefeita e foi aprovada pela população... foi reprovada... tanto é que você não foi reeleita... e... a minha gestão é muito bem avaliada... seSSENta por cento dos paulistanos entendem que ela é ótima ou boa... e o serviço de saúde e de eduCAÇÃO... melhoraram sim... melhoraram MUlto... TANto é... que esse mesmo lbope que você cita aqui... um instituto de muita credibilidade... assim como o Datafolha... mas voltando ao lbope... nós TEmos que... TOdos os usuários do sistema... público de saúde... em especial... aquele voltado as Amas... um MIlhão de pessoas por mês... deram nota acima de NOve... do Mãe Paulistana... nota acima de NOve... dos DOis novos hospitais... nota acima de Olto... e hoje... eu quero dizer a você... telespectador... que a ex-prefeita fez um desafio querendo saber... quem conhece o programa Remédio em Casa... quem conhece uma pessoa que recebe o Remédio em Casa... São Paulo tem ONze milhões de habitantes... desses ONze milhões de habitantes... nós temos CENto e vinte mil pessoas... que recebem o remédio em casa... são os usuÁrios desse programa... são faMílias atendidas... e nós vamos continuar ampliANdo esse sistema... porque nós não TEmos preocupação de colocar o nome em placa... ou atender de uma maneira (macro) tudo... nós temos preocupação de fazer com qualidade... e melhorou MUlto o sistema público de saúde conosco...

L3: Kassab... você não respondeu... eu coloquei... que sessenta e nove por cento... através da pesquisa lbope... consideRARAM a saúde ruim e péssima... você está desrespeiTANDO as pessoas que voTARAM... e seTENta por cento... colocaram como MUlto ruim... a... a avaliação... na demora dos exames... você está desrespeiTANDO esse cidadão... você PINça algumas pesquisas referentes... à alGUNS programas... que se estão bons... nós VAmos contiNUAR... mas nós VAmos fazer funcionar a saÚde... como sistema inteGRAdo... que é o jeito como a saúde tem que funcioNAR... que a pessoa que entre pela Ama... que é a porta de enTRAda... ela consiga fazer um exame numa poliCLínica... na região DEla... a pessoa que entre por uma Ubs... consiga fazer um exame na policlínica na região DEla... aquele exame de tomoGRAFIA... que hoje demora... quanto tempo?... dez meses... que eu esCUto... e que faz setenta per/... por cento dos usuários... estarem insatisfeitos... então há uma MANIpulação de dados... 
L2: o que te incoMOda... Marta... o que te incomoda muito... é que quando você prefeita... você foi MUlto mal na saúde... você gastou... no último ano... quase quinze por cento do orçamento... você investiu quinze por cento do orçamento em saúde... que é o que a lei exige... eu estou investindo QUIn/... VINte por cento do orçamento... e por que?... voltando a pergunta anterior... eu não fiz túneis no jardins... eu não deixei o fura-fila inacabado... não é?... eu usei os recursos com muita austeridade... e por isso eu estou investindo VINte por cento dos recursos na saÚDE... e fiz MUlta coisa... e tenho humilDAde de dizer aqui... que FALta muito por fazer... mas essa pesquisa do lbope... o que vale mesmo é a pesquisa do Ibope com os usuÁrios do serviço... aqueles que usam o serviço... e os novos serviços estão avaliando MUlto bem... eu estou MUlto contente com os resultados na área da saúde... mas falta MUlto por fazer... e... o que te incomoda... é que você foi MUlto mal na saúde...

L1: candidato Kassab faz agora a sua pergunta à candidata Marta... e o tema... vamos aqui ao sorteio... o tema é... educação...

L2: a educação... educação é... um tema fundamental... eu queria... perguntar aqui... à candidata Marta... QUAl é... a sua prioridade número um para a educação?...

L3: a minha prioridade número um pra educação... é... além de fazer os Ceus que você não está completando... e nem vai entreGAR... é fazer mais VINte nos luGAres ONde não tem NAda nessa cidade... como Vila BELA... Parque das Flores... luGAres extreMAdos da cidade... onde os Ceus vão ser utilizados... como instruMENTO de inclusão social... agora... Kassab... você está falando de uma coisa que eu gosto MUlto... que é a minha Área... e onde eu investi... vou investir muito... que é a qualiDAde... nós vamos dar autonoMIA para as escolas... por que?... as escolas... tem que estabelecer as SUas metas... fazer as SUas avaliações... para poder... chegar num patamar... pra passar na prova Brasil... porque as escolas da cidade de São Paulo hoje... como você bem sabe... tão pela meTAde da nota nacional... nós vamos investir então no professor... por que?... o professor hoje... ele pode até estar querendo ensinar... mas ele quer ensinar matemática para aquele aluno que não aPRENde?... ele não tem instrumento... então não adianta ficar exigindo do professor... nós vamos fazer um CENtro... de formação contiNUADA do professor... e vai formá-lo... naQUllo que a SUa esCOla decidir... que é o que preClsa... que ELE acha que precisa... porque o professor que está dando aula... Maci/... em Parelheiros... em Marsilac... e que tem os seus problemas... ele tem crianças que... elas convivem na zona RUral... tem vaca... elas conhecem... a criança que está na Freguesia do Ó... ela conhece outras coisas... ela não conhece aquilo... então sem ter a experiência... sem coBHEcer... qual é a realidade daquela criANÇA... o professor não consegue ensiNAR... mas muitos não tem ainda... a diDÁtica... a formação... se esforçam... não conseguem... nós vamos fazer essas duas coisas... eles vão se avaliAR... vai ter o centro de formação continuAda... e vai ter um NÚcleo... de avaliaÇÃo consTANte... em relação ao professor... Olha... em QUAtro anos... se a gente não pág/... passar nessa prova nacional... nós vamos estar bem pertinho... porque nós vamos investir... de FAto... porque sem investir no professor... nós NÃO VAmos conseguir dar esse salto... e para isso... é como eu disse... tem que ter... cada escola sua autonoMIA... a sua avaliação... saber do que ela necessita...

L1:

candidata... o seu tempo acabou...

L2: é... infelizmente... quando ela foi prefeita ela não investiu no professor... eu queria aqui... registrar... que a Prova Brasil identificou uma melhora da qualidade do ensino... do primeiro e do segundo ano... de nossa rede pública municipal de 
ensino... por que?... porque nós implantamos o programa Ler e Escrever... que é um profesSSOR... e um professor assistente na sala de aula... na fase de alfabetização... no início de nossa gestão... o índice de analfabetos... de pessoas que chegavam ao final do segundo ano sem saber ler e escrever... era trinta e cinco por cento... ele foi reduzido pelo programa Ler e Escrever... para QUINze por cento... e continuAMOS avançando... eu queria perguntar à candidata Marta... em relação ao programa Ler e Escrever... o PROfessor... mais o aSSIStente em sala de aula... se ela vai continuar esse programa... e se ela vai continuar também 0 programa Minha Biblioteca?...

L3: olha... eu acho que o pro/... o que o professor mais precisa hoje... é ser ajudado a ensiNAR... você pode por TRÊS... não precisa ser dois... aliás... nem tem dois... hoje a gente sabe... que tem um professor... quando TÁ... e um estagiário raraMENTE... quarenta por cento das mães... já responderam isso em pesquisa... mas o que Nó precisamos hoje... é ajudar o professor a ensiNAR... não adianta você por um monte de professor que não está prepaRADO... que está desespeRAdo... que não tem condição de trabalhar numa aula só... numa escola Só... isso é uma das coisas primeiras que eu vou fazer... dar condição ao professor entrar nu/... numa só escola... porque se ele tem que ficar girando em várias escolas... ele nem prepara a AUla... então por isso que eu digo... as escolas vão ter que ter essa autonoMla... elas vão conseguir poder se avaliAR e ter o seu centro de formaÇÃo continuAda... agora... você fez uma Prova São Paulo... que NÃO apresentou os resultados... ficaram prontos o ano passado... e tenho certeza que está esperando acabar a eleição para apresentar os resultados... porque na PROva nacioNAL... meTAde das escolas de São Paulo... duZENtas e dezenove... pontuAram... a meTAde do... do Brasil...

L1: candidata... a senhora agora faz a sua pergunta... e o TEma do sorteio é... Dívida pública...

L3: dívida pública... eh:.... Kassab... eu recebi a ciDAde de São PAUlo... com uma dívida giganTESca... feita por você... que era o secretário de planejamento... e na época... planejamento lidava com o orçamento... bom... a dívida pública de São Paulo... foi... na gestão de vocês... de CINco BI para VINte e UM BI... a situação ficou TÃO difícil... que vocês tiveram que negociar com o Governo Federal... Fernando Henrique... deixaram uma situação calamitosa... eu quero saber... com esses títulos...

L1:

[

L3: candidata... que foram feitos... aonde

foram os recursos?...

[

L1: $\quad$ candidata... acabou o seu tempo... por gentileza...

L2: uma das coisas MAis importantes que tem na administração pública... é deixar o nome limpo na praça... você deixou a prefeitura de São Paulo QUEbrada... DOis bilhões de reais de dívidas... isso é de conhecimento público... TREze mil credores... eu posso afirmar que... em relação à dívida pública... hoje... nós viRAmos a página na cidade de São Paulo... você diz que encontrou a cidade quebrada... nós encontramos... DUas vezes quebrada... nós coloCAMOS a casa em ordem... nós invesTIMOS... passamos a investir em saúde... em educação... hoje... as contas estão rigorosamente em dia... nós inclusive... em relação a esse tema... nós... posso afirmar ao telespectador... que não criamos TAxas... não criamos impostos... ao contrário... estamos devolvendo treZENtos milhões de reais de Iptu... para as pessoas que usaram a nota fiscal eletrônica... portanto 
dívida pública é algo que não está na nossa gestão... é um tema que não existe... tivemos... MUltas dificuldades no começo... e hoje temos a felicidade de investir no metrô... de investi em corredores de ônibus... de investir na construção de parques... de fazer uma cidade melhor... uma cidade com atendimento público de saúde de mais qualidade... com ensino público de mais qualidade... e eu tenho certeza absoluta... que o telespectador... que se recorda da época da ex-prefeita... quando era um governo voltado para a criação de TAxas e mais taxas... e eu pergunto aqui... a nossa ex-prefeita... candidata Marta... PRA que tanta TAxa?... bastava não jogar dinheiro fora com TÚnel... com obras que... estavam mal encaminhadas... com contratação de assessores de confiança... não precisava... era TAxa demais... até você pediu desculpas... mas... as pessoas tem dificuldade de entender o pedido de desculpas...

L3: Kassab... não adianta você se furtar a responsabilidade da dívida que vocês deixaram para a cidade... e como vocês queBRAram a cidade... as próximas gerações vão ter que pagar TREze por cento do orçamento dessa cidade para dar conta da dívida que vocês deixaram... eu sei porque eu recebi a cidade acaBAda... não era só saúde... era a educação e o transPORTE... então por MAis que você fale... quem tem memória... lembra dos escândalos dos precaTórios... que foram emitidos Títulos... para pagar precatórios... esses títulos foram emitidos... e o dinheiro de-as-pa-re-ceu... os precaTÓrios é que geraram... toda essa dívida da cidade... isso está lá... Cpi dos PrecaTóRIOS... a responsabilidade correndo na justiça... e quanto ao dinheiro que vocês vão isentar do Iptu... é bom que isente mesmo... vocês aumentaram em duzentos mil o número de pessoas que estão pagando Iptu nessa ciDAde... e virou Iptu mais CAro... além do... do Iss... que você aumentou... aliás... você fez novas... posso chamar de uma taxinha... de dois por cento... para TAxista... músico e alfaiate...

L2: o taxista... o alfaiate... a manicure... o cabeleireiro... a cabeleireira que está nos ouvindo sabe que nós... estamos isenTANdo o Iss dos profissionais autônomos... e também sabe... que eu nunca fui o responsável pelo orçamento... a não ser nesse momento... como prefeito da cidade de São Paulo... eu quero dizer... a todos vocês... que:.... os treze por cento da dívida que pagamos... todos os meses... ele tem sido pago rigorosamente em dia... nós hoje... temos a cidade de São Paulo com a saúde financeira... temos condição de investir... temos... enfim... uma cidade muito bem organizada... uma administração muito bem organizada... e eu lamento aqui... dizer para a ex-prefeita que sempre é recorrente... ela investiu mal... ela não acabou com as salas de lata... com as escolas de lata... vem sempre com a história de Pltta... mas não explica porque ela não se afastou do pessoal do MENsalão... porque eu me afastei do Pitta...

L3: olha... você sabe muito bem...

L1:

por favor... agora o candidato KaSSAb faz a sua

pergunta... e o tema é... geRA-ÇÃO de empregos...

L2: geração de empregos... o combate ao desemprego é uma questão fundamental na cidade de São Paulo... nós... tivemos oportunidade com o programa São Paulo Confia... de aumentar... o valor... eh... de financiamento... de VINte milhões para sessenta milhões... e também... criamos o Centro de Atendimento ao Trabalho... que nos deu a oportunidade de eNORmes avanços na questão do emprego... pergunto à candidata... ela vai manter os Centros de Atendimento ao Trabalho?...

L3: eu acredito... tudo o que for... para gerar emprego... manter emprego... a gente vai fazer... vai manter... tudo o que é de bom nessa cidade... nós vamos contiNUAR... porque não tem nada que ser extinto e recomeçar... se está 
funcionando bem... agora... eu quero falar... que você... não fez o Ceu profissionaliZANTE... nós temos todos os vinte e um Ceus que eu deixei... os quatorze que você está faZENDO... e esses Ceus... já poderiam estar com escolas profissionaliZANTES... você VEtou o projeto que veio da CÂmara... onde já podia estar acontecendo há QUAtro Anos... há quatro anos você está lá... com DEZ Bllhões a mais... TOdo Ano... que poderiam estar sendo usados em qualificação... e eu gostaria de lemBRAr... Kassab... que o... a secretaria de trabalho tua... é das piores entre todas... porque... ela utilizOu... eu vou dar um dado... dezesseis por cento só dos reCURsos... pro BOLsa fa/... Bolsa TraBALHO... sabe o que é o Bolsa Trabalho?... é o Bolsa Trabalho pro jovem... é o que fazia qualificAção para a juventude... você não conseguiu usar o dinheiro... $\mathrm{E}$ também... praticamente... PArou... o ocupação... o Começar de Novo... que é para pessoas com quarenta anos... que quer ter uma ocupação... a dona de casa que QUER voltar ao mercado de trabalho... e não é qualifiCAda... PAra aquela pessoa de... na operação trabalho... que tem BAlxa qualificação... que não tem condição... e que vai fazer um trabalho humilde... vai ter um salário... isto praticamente a tua secretaria acabou... o... o São Paulo CONfia... podia ter crescido enormeMENte... ficou ali pequenininho... então todos os grandes proJEtos inovaDOres dessa ciDAde... que colocaram São PAUlo... como a cidade de maior projeÇÃO... em projetos SOciais DO BRAsil... você... reduziu muito... inclusive o Renda Mínima... reduziu o cadastro pela meTAde... o Bolsa Família... deixou de utiliZAR... uma quantidade giganTESca do Bolsa FaMÍLIA... e o que mostra que pessoas... gente... realmente não é a sua prioriDADE...

L2: as pessoas que nos assistem sabem a nossa preocupação com as pessoas... principalmente aquelas... MAis precisam do poder público... aquelas que... precisam morar com digniDADE... aquelas que precisam de um ensino público de qualiDADE... uma saúde pública de qualiDADE... mas eu queria dizer que... os nossos... Cats... foram responsáveis pela... contratação... e geração de cento e cinquenta mil empregos com carteira assinada... o seu programa São Paulo Inclui... ele gerou CINco mil empregos... eu queria também dizer que... é significativo sim... aumentar de VINte milhões de financiamento para sessenta milhões... com JUros menores... o valor financiado pelo programa São Paulo Confia... porque tudo o que nós fizemos ao longo dessa gestão foi com muito equilíbrio... com muita seriedade... nós triplicamos... você está menosprezando os SEUs números... se você financiou VINte milhões de reais... eu financiei sessenta e você acha pouco... e os vinte que você financiou...

L3: Kassab... tudo isso que você falou... a gente não vê nas ruas... a gente não vê as pessoas reconhecidas... as pessoas aproveitando tudo isso... o que eu sei... é que o projeto de QUAlificação... e o recurso que veio do governo LUla... para investir na... nos jovens... você devolveu... sabe quanto?... dezessete milhões... você mandou de volta... você não uSOU... na qualificação do nosso jovem... não sei por que... aQUI Kassab... a minha prioriDADE... seRÁ... essa população abandoNAda... por que?... porque a cidade de São Paulo... RIca como é... não pode ter GENte na rua... povo da rua abandoNAdo... o BoraCÉIA... que é aquele abrigo que era referência INternacional... que foi totalmente dilapidada... para que que ele servia... as pessoas abandonadas... os abrigos não funcionando mais do jeito que funcionavam... a qualificação das pessoas huMILdes... que TÃO na RUa... você também interrompeu... o BOLIsa AluGUEL... a locação social... tudo isso acabou na cidade de São Paulo... Kassab...

L1: encerramos assim... mais este... o último bloco... ((aplausos))... de perguntas entre os candidatos... logo depois do intervalo... os candidatos 
retornam... e cada um terá três minutos para as considerações fiNAIS desta camPAnha... nós voltaremos em dois minutos... até já...

((vinheta do intervalo comercial))

L1: esTAmos de volta com o deBAte para preFElto de São Paulo... este é o ÚLtimo bloco... e cada candidato terá três minutos para deijar/... deixar a sua mensagem... aos eleitores... eu vou agora sortear... quem Abre este bloco... candiDAta MARta SupliCY tem três minutos para as suas consideraÇÕES finais...

L3: primeiro eu quero agradecer à Rede Globo... a você... Chico Pinheiro... pela mediação... à plateia... ao candidato Kassab... e a você... eleitor ou eleitora que está em casa nos assistindo... eu acho que nós tivemos a oportunidade de ver duas candidaturas... duas posturas... e dois JEitos de governar... nos vimos um jeito que trata a favela do Jardim Egito/... Edith daquela forma... mas nós vimos também o jeito de alguém... que... quando VAi naquela favela do Jardim Cumbuçu... depois vem racionalMENte dizer... que ali não pode consertar a favela toda... arruMAR... porque passava um fio de alta tensão... eu tive IÁ eu vi... e passa $\operatorname{sim} .$. agora... fez um muro... invés de... deixou as pessoas do lado do fio de alta tensão no perigo... e tem uma portinha... naquele muro... então essa é a pessoa... eu fico olhando aquilo... olha gente... o q/... o que eu senti quando eu vi... eu pensei... veio um menininho... que falou para mim... quando é que eu vou morar do lado do MUro?... essa é a gestão... de Gilberto Kassab... aí você pensa... mas talvez... se tivesse feito isso... feito aquilo... não tem obra licitada de grande porte... continuou o que eu havia feito... né?... e depois de dois anos parado... como os Ceus... não vai entregar... o que prometeu... e de outro lado... você tem uma pessoa... que pegou uma cidade desTRUÍDA... conseguiu trabaLHAR... conseguiu ter parceRIAS... que acabo construindo aquele auditório LINdo no IbiraPUERA... as fontes li/... luminosas da cidade de preSENTE... arrumou tantas praças na ciDADE... arrumou o centro da cidade... conseguiu esse recurso do exterior do Bid... que permitiu a recuperação do nosso centro... fez habitação popuLAR... fez o bilhete único... fez o Ceu... com tão pouco... com tão pouco... com dez bilhões a menos... por ano... e agora... eu me proponho... a fazer muito mais... a cidade está muito mais rica... GRAças ao desenvolvimento econômico que São Paulo tem... um orçamento hoje... de dez bilhões a mais todo ano... o que vai dar para a gente fazer... uma revoLUÇÃO na eduCAÇÃO... uma revolução... na quaLIDADE... do ensino da nossa cidade... nós manTEREMOS os Ceus... ampliaremos... para ser um instrumento de inclusão social... mas a gente vai investir no profeSSOR... e tem... e vai ser uma coisa TÃO ouSAda... quanto foi ousado fazer Ceu... e na saúde?... na saúde nós vamos fazer o que eu falei... nós vamos melhorar as Amas... as Ubss... o programa Saúde da Família... fazer as policlínicas... fazer o sistema funcioNAR... e agora no transporte... no transporte eu sei DIreitinho... a gente vai começar... investindo na Cet... para colocar... peSSOAS nas ruas tomando conta do trânsito... a gente vai fazer MAis corredores de ônibus... duzentos e vinte e oito quilômetros... e investir no metrô... que agora tem recurso... levei para o presidente LUla... o PLAno de Mobilidade Urbana... pra São Paulo enquanto ministra... está aproVAdo... VEM recurso federal... VEM recurso da prefeitura... e a cidade vai melhorar MUlto...

L1: e agora... para as suas considerações finais... o candidato Gilberto Kassab...

L2: quero cumprimentar à Rede Globo... ao Chico Pinheiro... à candidata Marta Suplicy... cumprimentar você telespectador... que participou... desse último deBATE... as eleições acontecem nesse doMINGO... são eleições MUlto importantes para a cidade de São Paulo... vão definir o fuTUro para a cidade nos próximos quatro anos... eu GOSto de ser prefeito de Sã/... eu gosto de ser prefeito 
da cidade de São Paulo... tenho me dedicado muito... eu vesTI a camisa da cidade de São Paulo... e hoje... eu tenho a alegria... tenho O orguLHO... de poder dizer a todos... que a cidade melhorou... as nossas ações na saúde pública... tiveram um resultados extraordinários... principalmente... para o usuÁrio de nossos serviços... isso... atestado por pesquisas muito bem feitas... as AMAs... são cento e quinze Amas feitas na cidade de São Paulo... DOis novos hospitais... há deZEssete Anos não tínhamos NOvos hospitais na cidade de São Paulo... contratamos MAis de três mil MÉdicos... hoje existem programas como o Remédio em Casa... como o Mãe Paulistana... que beneficiam MILHAres de pessoas... hoje nós podemos dizer... que as crianças que estudam na rede pública municipal de ensino... elas estudam com dignidade... os professores estão motivados... eles conflam no poder público municipal... eles sabem que... nós estamos preocupados... com a melhoRIA da qualidade... estamos preocupados em motivá-los... dando condições salariais... capaciTANdo os professores para que eles estejam preparados para a... fazer PARte desse projeto Melhoria da Qualidade do Ensino Público... hoje nós temos São Paulo mais bonita... São Paulo do Cidade Limpa... hoje nós temos uma cidade de São Paulo que sabe que nós temos rumo para combater a poluição do ar... implantamos a inspeção veicular... tinha a cidade de São Paulo antes da minha gestão TRINta e um parques... vamos deixar a cidade de São Paulo com sessenta e três parques... e para a próxima gestão... mais quaRENta novos parques... porque meio ambiente é muito importante... não existia investimentos em meio ambiente... TRIplicamos o orçamento da Secretaria do Verde e do Meio Ambiente... fizemos a Virada Cultural... fizemos... aqui... a Virada Esportiva... nós beneficiamos... com esses eventos... Mllhões de pessoas... nós temos condição de afirmar... que nos próximos quatro anos... nós vamos deixar a cidade melhor ainda... nós temos aqui condições de afirMAR que... o nosso grande orgulho hoje... a nossa grande alegria... o caRInho com que temos sido recebidos na rua... as própria pesquisas mostram que a... sessenta por cento dos paulistanos entendem que a nossa administração é ótima ou boa... e eu quero aqui deixar registrado... um Único SOnho meu... o meu MAior sonho é que daqui há QUAtro anos... assim como tenho sido recebido nas ruas hoje... que eu continue sendo recebido da mesma maneira... que as pessoas... dêem um toque no meu ombro... e valem... valeu Kassab... cê foi um bom prefeito... você honrou o nosso voto... porque daí sim... o meu serviço vai estar concluído... muito obrigado... até as eleições... se DEus quiser...

L1: e aSSIm... enceRRAmos o ÚLtimo deBAte entre os candiDAtos para a prefeitura de São PAUlo... nas eleições de dois mil e oito... nós agradeCEmos a participaÇÃO... a presença da candidata Marta SupliCY... do candidato Giberto KaSSAb... aos candidatos aqui presentes... e principalmente a voCÊ... eleitor... que nos honrou com a sua audiência... nós vamos acompanhar os momentos de camPAnha... desses candidatos... e domingo... depois de amaNHÃ... vinte e seis de ouTUbro... você terá cobertura completa aqui na Tv Globo... de TOdo o proceSSO de votação e apuração... nessas eleições municipais de dois mil e oito... NÃO esqueçam... de exercer BEM... o seu direito de ser cidadão... e VOtem... tenham TOdos... uma BOA noite... e que tenham um bom voto... obrigado... ((aplausos))...

((vinheta de encerramento do programa))

L4: (olá) o debate decisivo à prefeito de São Paulo TERminou mas a movimentação nos estúdios da Tv Globo ainda é grande... Gilberto Kassab e Marta Suplicy conversam com os seus assessores... e os conviDAdos também por aqui... vamos dar um giro... primeiro com o repórter CéSAR Menezes... 
L5: Rodrigo... estou aqui com Alda Marcoantonio do Pmdb... candidata a VIce na chapa do candidato Gilberto Kassab... sua opinião sobre o debate...

L6: eu adorei o debate... foi de alTÍssimo nível... e o meu candidato... o prefeito Kassab... demonstrou... como em TOda camPAnha... uma eleGÂNcia acima de tudo... compeTÉNcia... e GAna por governar... ele GOSta de ser prefeito da cidade de São Paulo... e quem GOSta do que faz... sempre procura melhorar... e é isso que ele faz todo dia... parabéns... Kassab... pelo alto nível do debate... por toda a sua competência...

L5: muito obrigado... Rodrigo...

L4: do outro lado está a repórter Verusca Donato...

L7: Rodrigo... aqui ao meu lado está o candidato a VIce... da candidata Marta Suplicy... Aldo Rebelo... o que o senhor achou do debate?...

L8: eu creio que foi muito bom para o eleitor de São Paulo... que pôde... ver a experiência... a capacidade... o humaNISmo... de nossa candidata... MARta Suplicy... que deseja...

((fim da gravação)) 